\title{
AVALIAÇÃO DE PROGRAMAS DE EDUCAÇÃO AMBIENTAL VOLTADOS PARA O GERENCIAMENTO DOS RESÍDUOS SÓLIDOS URBANOS
}

Sandra Maria Furiam Dias

Tese de doutorado apresentada ao Departamento de Saúde Ambiental da Faculdade de Saúde Pública da Universidade de São Paulo para a obtenção do Grau de Doutor.

ORIENTADORA: PROF ${ }^{\mathrm{a}}$. DR ${ }^{\mathrm{a}}$. WANDA $\mathrm{M}$. RISSO GÜNTHER 
Ao Tayser e aos meus filhos Elisa e Gabriel 


\section{AGRADECIMENTOS}

A Universidade Estadual de Feira de Santana por ter dado as condições materiais para a realização do curso de doutorado.

Ao Departamento de Saúde da UEFS pelo apoio logístico e administração do curso, especialmente, ao coordenador do curso na UEFS Professor Guido Rummler e a funcionária Tânia Lago.

Aos colegas do Departamento de Tecnologia da UEFS pelo incentivo e ao Professor Elói Barreto pela leitura inicial do projeto de tese.

A minha orientadora Professora Wanda Risso Günther pelo apoio e sugestões importantes ao trabalho, pela paciência nas correções dos meus escritos e pela acolhida em São Paulo.

Aos professores docentes e orientadores do curso pela importante contribuição na minha formação profissional, em especial, ao Professor Fernando Lefrève pela orientação na coleta e organização dos dados. Aos coordenadores do curso em São Paulo, Professores Paulo Carvalho Cortes e Evelin de Castro Sá pelo apoio.

Aos colegas do curso pelos bons momentos de convivência e troca de experiências. Especialmente aos colegas Silvio Orrico e Maridalva Penteado pelas produtivas conversas ao telefone.

Agradecimento muito especial aos colegas da Equipe de Educação Ambiental (EEA) da UEFS. A todos os professores, alunos e funcionários que passaram pela EEA e aqueles que ainda permanecem pelos ensinamentos ao longo da trajetória da Equipe. Agradecimento especial à funcionária Arlene Novaes pela viabilização de materiais para a coleta de dados, pelo apoio logístico e pelo companheirismo ao longo desses oito anos que trabalhamos juntas na EEA. Ao Professor Luciano Vaz pela leitura e sugestões pertinentes ao trabalho e pela formatação final da tese. Ao Professor Luiz Ferraro e a estagiária Dora pela ajuda na fase final do trabalho.

Ao pessoal da Associação Comunitária do Arraial de São Francisco da Mombaça pelos bons momentos de convivência e pelos conhecimentos adquiridos ao longo desse tempo de parceria com a EEA. 
A todos os professores, alunos e funcionários da UEFS, bem como aos moradores do Arraial de São Francisco da Mombaça e de Mucugê e técnicos da CAR que facilitaram os dados e as entrevistas.

A Neize e Aurélio Chateaubriand pelo carinho com que me receberam em sua casa em São Paulo.

Com carinho todo especial agradeço aos meus pais que sempre incentivaram os estudos, ao meu marido Tayser, aos meus filhos Elisa e Gabriel pela compreensão da ausência e que sempre me deram muita força. 


\section{RESUMO}

Dias SMF. Avaliação de programas de Educação Ambiental voltados para o gerenciamento dos resíduos sólidos urbanos. São Paulo. [Tese de Doutorado - Faculdade de Saúde Pública da USP]

O modelo tecnológico-industrial vigente incorpora, na sociedade, valores de consumo, e, conseqüentemente ocorre um aumento na geração de resíduos sólidos. Os impactos do manejo inadequado desses resíduos sólidos no ambiente e na saúde são inúmeros. Neste contexto, o desafio que se apresenta é a transformação da sociedade de consumo em uma sociedade sustentável, responsável pelo resíduo que produz e pelo seu gerenciamento adequado. A Educação Ambiental promove a reflexão crítica sobre a problemática ambiental e concorre para a transformação dos sistemas que a sustentam. Foram avaliados, nesta pesquisa, três programas de Educação Ambiental que tiveram como foco o lixo urbano. Os programas estudados foram: os desenvolvidos no campus da Universidade Estadual de Feira de Santana, no Arraial de São Francisco da Mombaça e no município de Mucugê, todos no Estado da Bahia. Na avaliação dos programas, utilizaram-se para a coleta de dados: entrevistas, relatórios, observações de campo, material impresso utilizado na sensibilização e, a quantificação da geração de lixo em cada localidade. Para a organização e análise dos dados das entrevistas, utilizou-se a metodologia do Discurso do Sujeito Coletivo. Pela análise dos dados obtidos, observou-se que a prática de Educação Ambiental realizada como suporte para a implantação do projeto de coleta seletiva na UEFS e em Mucugê foi orientada para a mudança de comportamento. Essa prática proporcionou a formação de hábitos responsáveis no descarte do lixo. Contudo, não conseguiu promover a compreensão das causas dos hábitos consumistas e de incorporar, de maneira geral, nas pessoas, a prática do descarte de lixo segregado. O projeto desenvolvido no Arraial foi baseado na mudança de sensibilidade através da leitura crítica do contexto e da ação para a resolução de problemas, proporcionando mudanças significativas na localidade e nas pessoas da comunidade.

Descritores: Educação Ambiental. Resíduos sólidos. Lixo. Gerenciamento de resíduos sólidos urbanos. 


\section{SUMMARY}

The modern patterns of technology and industry implies in a society based on consumption (or vice-versa) and consequently on the significant generation of solid wastes. There are several impacts on the environment and health due to a inadequate solid waste management. This context brings the challenge of turning the Consumption Society into a Sustainable Society, responsible for the wastes it generates and its adequate management. The Environmental Education promotes a critical reflection on environmental problem towards the transformation of the systems which sustain this problematic scenario. Three Environmental Education Programs focusing Urban Wastes have been evaluated on this research: the program developed at Feira de Santana State University Campus, at São Francisco da Mombaça district and the program of the municipality of Mucugê, all of them located in the State of Bahia. The data collection for the evaluation of the programs have been done through interviews, field observations, official reports, printed material used for sensibilization and due to the quantification of solid wastes generation. The methodology of "Collective Stakeholder Speech" has been used to organize and analyze the interviews. Due to the analysis of data it has been observed that the Environmental Education actions used to support the Recycling Collection Projects of UEFS and of Mucugê were based on behavior changing. This kind of action stimulated responsible habits on waste disposal. However it has failed on promoting a broader understanding of consumption habits and at consolidating the compromise of segregated waste disposal. At the District the project was based on sensibility due to a critical reading of the context and on action for problem solving, it has promoted significant changing on the community and its people.

Key-words: Environmental Education, Solid Waste, Garbage, Urban Solid Waste Management. 


\section{SUMÁRIO}

1.1 A Sociedade e o Lixo 1

1.2 Sustentabilidade, Ambientalismo e Participação 6

$\begin{array}{lll}\text { 1.2.1 O Papel da Universidade } & 14\end{array}$

$\begin{array}{ll}1.3 \text { Educação Ambiental } & 16\end{array}$

1.3.1 Educação Ambiental e Sustentabilidade 20

1.3.2 Avaliação dos Programas de Educação Ambiental voltados para os 24 Resíduos Sólidos Urbanos

$\begin{array}{ll}1.4 \text { Resíduos Sólidos } & 28\end{array}$

$\begin{array}{lll}\text { 1.4.1 Definição } & 28\end{array}$

$\begin{array}{lll}\text { 1.4.2 Classificação } & 28\end{array}$

1.4.3 Os Resíduos Sólidos no Brasil $\quad 30$

1.4.4 Legislação Federal sobre Resíduos Sólidos 33

1.4.5 Características dos Resíduos Sólidos gerados em Ambientes 36 Universitários

1.4.6 Resíduos Sólidos, Saúde e Meio Ambiente 37

1.4.7 O Lixo: da Geração à Destinação Final e Possibilidades de seu 45 Gerenciamento

1.4.7.1 Processamento dos Resíduos Sólidos $\quad 49$

1.4.7.2 Disposição Final dos Resíduos Sólidos $\quad 50$

1.4.7.3 Gerenciamento dos Resíduos Sólidos Urbanos $\quad 52$

1.4.8 Educação Ambiental no Gerenciamento dos Resíduos Sólidos 56

2 OBJETIVOS

2.1 Geral $\quad 58$

2.2 Específicos $\quad 58$ 
3.1 Método de Investigação

3.2 Cenário da Pesquisa 59

3.3 Sujeitos Participantes

3.3.1 Características da população pertencente à comunidade da UEFS 62

3.3.2 Características da população pertencente à comunidade do Arraial de 62 São Francisco da Mombaça

3.3.3 Características da população pertencente à comunidade de Mucugê 63

3.4 Passos Metodológicos 64

3.4.1 Pesquisa Bibliográfica $\quad 64$

3.4.2 Pesquisa Documental 64

3.4.3 Entrevista Individual $\quad 64$

3.4.4 Observação de campo não estruturada 65

3.5 Organização e Análise de Dados $\quad 66$

4 AVALIAÇÃO DOS PROGRAMAS DE EDUCAÇÃO AMBIENTAL VOLTADOS PARA O GERENCIAMENTO DO LIXO

4.1 Programa de Educação Ambiental na Universidade Estadual de Feira de 68 Santana

4.1.1 Caracterização da Universidade 68

4.1.2 Descrição do Projeto Coleta Seletiva e Reaproveitamento do Lixo 70 gerado no campus da Universidade Estadual de Feira de Santana 4.1.2.1 Gerenciamento do lixo na UEFS 73

4.1.2.2 Educação Ambiental no Projeto Coleta Seletiva e Reaproveitamento $\quad 80$ do Lixo gerado no campus da Universidade Estadual de Feira de Santana

4.1.3 Atividades e materiais de sensibilização e informação sobre a coleta 81 seletiva

4.1.3.1 Cartazes $\quad 81$

4.1.3.2 Adesivos explicativos $\quad 85$

4.1.3.3 Recepção dos alunos ingressantes nos cursos de graduação 85

4.1.4 Indicadores de geração de resíduos sólidos urbanos na UEFS 86 
4.1.5 Considerações sobre os questionários aplicados à comunidade universitárias, nos anos de 1996, 1998 e 1999.

\subsubsection{O Discurso do Sujeito Coletivo}

4.1.6.1 O Discurso do Sujeito Coletivo sobre o projeto de Educação

Ambiental desenvolvido na UEFS

4.1.6.2 O Discurso do Sujeito Coletivo sobre as mudanças ocorridas no campus em função do projeto

4.1.6.3 O Discurso do Sujeito Coletivo sobre as mudanças pessoais ocorridas em função do projeto

4.1.6.4 O Discurso do Sujeito Coletivo sobre a participação da comunidade no projeto

4.1.6.5 O Discurso do Sujeito Coletivo na avaliação do projeto

4.1.6.6 O Discurso do Sujeito Coletivo sobre a relação pessoal com o lixo

\subsubsection{Conclusão}

4.2 Projeto de Educação Ambiental no Arraial de São Francisco da Mombaça

- Bahia

4.2.1 Caracterização do Arraial de São Francisco da Mombaça

4.2.2 Descrição do projeto desenvolvido no Arraial de São Francisco da Mombaça

4.2.2.1 Projeto Terra Viva - O que Queremos?

4.2.2.2 À Sombra de uma Jaqueira. Projeto - Escola/Comunidade

Rural/Cidadania

\subsubsection{O lixo no Arraial}

4.2.4 O Discurso do Sujeito Coletivo

4.2.4.1 O Discurso do Sujeito Coletivo sobre o projeto.

4.2.4.2 O Discurso do Sujeito Coletivo sobre mudanças ocorridas no Arraial em função do projeto

4.2.4.3 O Discurso do Sujeito Coletivo sobre as mudanças pessoais ocorridas em função do projeto

4.2.4.4 O Discurso do Sujeito Coletivo sobre a participação da comunidade no projeto

4.2.4.5 O Discurso do Sujeito Coletivo na avaliação do projeto 
4.3 Programa de Educação Ambiental no município de Mucugê

4.3.1 Caracterização do Município

4.3.2 Descrição do projeto

4.3.2.1 Coleta Seletiva e Usina Simplificada de Reciclagem e Compostagem de Lixo

4.3.2.2 Projeto de Educação Ambiental

4.3.3 Avaliação pela CAR do Projeto de Educação Ambiental desenvolvido em Muugê

4.3.4 Materiais de sensibilização e informação sobre a coleta seletiva

4.3.5 Indicadores de geração de resíduos sólidos urbanos em Mucugê

4.3.6 Relançamento do projeto

4.3.7 O discurso do sujeito coletivo

4.3.7.1 O Discurso do Sujeito Coletivo sobre o projeto de Educação

Ambiental desenvolvido em Mucugê

4.3.7.2 O Discurso do Sujeito Coletivo sobre as mudanças ocorridas em

Mucugê em função do projeto

4.3.7.3 O Discurso do Sujeito Coletivo sobre as mudanças pessoais ocorridas em função do projeto

4.3.7.4 O Discurso do Sujeito Coletivo sobre a participação da comunidade no projeto

4.3.7.5 O Discurso do Sujeito Coletivo na avaliação do projeto

4.3.7.6 O Discurso do Sujeito Coletivo sobre a relação pessoal com o lixo

\section{ANEXOS}

Anexo 01 - Programa de Educação Ambiental desenvolvido na Universidade Estadual de Feira de Santana - Expressões-chave. 
Francisco da Mombaça - Expressões-chave.

Anexo 03 - Programa de Educação Ambiental desenvolvido em Mucugê -

Expressões-chave.

Anexo 04 - Roteiro da Entrevista

Anexo 05 -Termo de Consentimento Livre e Esclarecido 


\section{LISTA DE GRÁFICOS}

Gráfico 1 Caracterização do lixo em localidades no interior da Bahia

\section{LISTA DE TABELAS}

Tabela 1 Destino do lixo coletado no Brasil e regiões durante os anos de 1992 e 2000

Tabela 2 Quantidade de lixo coletado e geração per capita no Brasil e regiões

Tabela 3 Quantificação de resíduos sólidos da UEFS em 1992 e a evolução da geração no período de 1994 a 2001

Tabela 4 Evolução dos indicadores de geração dos resíduos sólidos na UEFS, de 1994 a 2001

Tabela 5 Evolução do per capita médio anual da geração de lixo na UEFS

Tabela 6 Acréscimo anual da geração de lixo na UEFS e do valor do per capita médio anual durante os anos de 1994 a 2001

Tabela 7 Percentual médio do lixo reciclável encontrado no lixo aterro gerado na UEFS, em 1994 a 1997 e 2000

Tabela 8 Composição gravimétrica do lixo produzido no Arraial de São Francisco da Mombaça, segundo duas caracterizações realizadas

Tabela 9 Resíduo segregado na Usina Simplificada de Reciclagem e Compostagem de Mucugê proveniente da coleta pública municipal, durante os meses de abril de 2000, 2001 e 2002

Tabela 10 Evolução do per capita médio diário da geração de lixo em Mucugê

Tabela 11 Acréscimo anual da geração de lixo em Mucugê e do valor do per capita médio diário durante os anos de 2000 a 2002 


\section{LISTA DE QUADROS}

Quadro 1 Responsabilidade pela coleta e destino final do lixo em função da fonte geradora

Quadro 2 Impactos ambientais, sanitários e efeitos econômicos causados pelo manejo inadequado do lixo urbano

Quadro 3 Enfermidade causada por vetores relacionados ao lixo 43

Quadro 4 Comportamento esperado da comunidade nas diferentes fases do sistema de gerenciamento, quando as estratégias educacionais estão pautadas na mudança de comportamento

Quadro 5 Idéias Centrais expressas pelos professores, alunos e funcionários da UEFS referente ao seu conhecimento sobre o projeto.

Quadro6 Idéias Centrais expressas pelos professores, alunos e 104 funcionários da UEFS referentes à percepção sobre mudanças no campus, em função do projeto

Quadro 7 Idéias Centrais expressas pelos professores, alunos e 109 funcionários da UEFS referentes a mudanças pessoais em função do projeto

Quadro 8 Idéias Centrais expressas pelos professores, alunos e 118 funcionários da UEFS referentes a sua participação no projeto

Quadro 9 Idéias Centrais expressas pelos professores, alunos e funcionários da UEFS sobre os aspectos em que o projeto poderia ser melhorado

Quadro 10 Idéias Centrais expressas pelos professores, alunos e funcionários da UEFS sobre sua relação com o lixo.

Quadro 11 Estimativa da produção de lixo em Mucugê, para os anos de 1998 e 2008. 


\section{LISTA DE FIGURAS}

Figura 1 Lixão a céu aberto ao lado da Usina de Reciclagem e 51 Compostagem do município de Sapeaçu - BA

Figura 2 Mapa situando os locais onde estão em curso os programas de 61 Educação Ambiental estudados.

Figura 3 Vista do pórtico de entrada da Universidade Estadual de Feira 68 de Santana

Figura 4 Sedes da Equipe de Educação Ambiental: (A) Antiga sede (B) Nova sede, inaugurada em outubro de 1997

Figura 5 (A) e (B) Acondicionadores para segregar o resíduo papel e o 76 aterro. (C) Antigos acondicionadores de maior porte para segregação do papel, vidro, metal, plástico e aterro instalados nas cantinas. (D) Baias de armazenamento do papel. (E) Pátio de compostagem. (E) Oficina de papel.

Figura 6 Figura 6 - Acondicionadores de maior porte para 79 armazenamento dos resíduos segregados. (A) Acondicionador de lixo aterro (B) Acondicionador para o lixo aterro e papel. (C) Acondicionador para papel instalado próximo ao CAU. (D) Acondicionadores para resíduos de serviços de saúde.

Figura 7 Local de armazenamento do lixo aterro para espera da coleta da Prefeitura Municipal de Feira de Santana.

Figura 9 Vista parcial do Arraial de São Francisco de Mombaça

Figura 10 Resultados do projeto desenvolvido no Arraial de São Francisco da Mombaça. (A) Roda de Bordado; (B) Resgate da Cultura Local (bumba-meu-boi); (C) Materiais produzidos em oficinas de papel e de brinquedos de sucata; (D) Fabricação de doces caseiros "Sabores da Terra".

Figura 11 Caracterização do lixo gerado no Arraial de São Francisco da Mombaça

(A) e (B) Coleta do lixo segregado; (C) Lixo coletado para a caracterização; (D) Pesagem do lixo 
Figura 12 Implementação da Praça Terra Viva

Figura 13 (A) Vista do terreno com o lixo; (B) Praça implementada, 155 vendo-se, ao fundo, as baias de armazenamento do lixo.

Figura 14 Vista parcial da cidade de Mucugê - Bahia

Figura 15 Entrada do local da sede do Projeto Sempre Viva, situado no Parque Nacional da Chapada Diamantina

Figura 16 Acondicionamento e coleta em Mucugê. (A) Coleta pública de 199 resíduos. (B) Lixo segregado à espera da coleta pública. (C) Lixeira pública

Figura 17 Operações realizadas na Usina Simplificada de Reciclagem e Compostagem de Lixo de Mucugê. (A) Vista da Usina. (B) Triagem dos materiais recicláveis, (C) Baias para armazenamento de lata e vidro. (D) Resíduos papel e plástico prensados e armazenados. (E) Compostagem do resíduo orgânico. (F) Enterramento do rejeito (após o relançamento da usina

Figura 18 Descarga do rejeito gerado na usina, observando-se uma quantidade significativa de resíduo reciclável sendo enterrado

Figura 19 Atividades realizadas em Mucugê para o relançamento da Usina Simplificada de Reciclagem e Compostagem. (A) Vista do local da realização das oficinas. (B) Oficina de cestaria. (C) Oficina de brinquedos de sucata. (D) Oficina de compostagem (E) Apresentação da banda de música local. (F) Oficina de papel 


\section{SIGLÁRIO}

CAR - Companhia de Desenvolvimento e Ação Regional

CAU - Centro Administrativo e Universitário

CHF - Departamento de Ciências Humanas e Filosóficas

CONAMA - Conselho Nacional de Meio Ambiente

CPD - Centro de Processamento de Dados

CRA - Centro de Recursos Ambientais

DAS - Diretórios Acadêmicos

DBIO - Departamento de Ciências Biológicas

DCHF - Departamento de Ciências Humanas e Filosóficas

DCIS - Departamento de Ciências Sociais

DDF - Departamento de Desenvolvimento Florestal

DLET - Departamento de Letras e Artes

DSAU - Departamento de Saúde

DTEC - Departamento de Tecnologia

EEA - Equipe de Educação Ambiental

MA - Módulos Administrativos

MPs - Módulos Práticos

MTs - Módulos Teóricos

PAT - Pavilhão de Aula Teórica

SEPLANTEC - Secretaria de Planejamento, Ciência e Tecnologia do Estado da Bahia.

TVU - TV Universitária

UEFS - Universidade Estadual de Feira de Santana

UNEB - Universidade do Estado da Bahia 


\section{INTRODUÇÃO}

\subsection{A Sociedade e o Lixo}

Compreendem-se por Resíduos Sólidos todos os resultantes das atividades humanas de origem industrial, doméstica, hospitalar, comercial, agrícola, serviços, varrição e, para a compreensão de sua problemática, devem ser considerados como resultado do desenvolvimento tecnológico que variou ao longo do tempo, assumindo, assim, um caráter histórico e social. Esse avanço afetou a quantidade e a qualidade dos resíduos produzidos pelo homem ao longo do tempo, e ocasionou impactos sanitários e ambientais decorrentes de sua disposição final, geralmente inadequada no solo, bem como da forma de percebê-los no ambiente.

Os seres humanos, dotados de uma capacidade não encontrada em outros animais, desde a idade primitiva, desenvolveram instrumentos e ferramentas, permitindo exercer a caça e outras atividades (trabalho). Observa-se que os resíduos sólidos gerados pelos seres humanos primitivos, por suas características de alimentação e por serem nômades, sofriam uma degradação natural, cumprindo o ciclo da matéria e da energia.

À medida que o homem se percebe diferente dos outros animais, tem necessidades e aspirações não naturais, no sentido de poder artificializar o meio para produzir, escolher, melhorar e explorar as espécies vegetais e animais. Como consequiência aparecem, entre os homens e a natureza, elementos especiais chamados bens econômicos. O equilíbrio ecológico é, então, alterado, ameaçando inclusive a sobrevivência da espécie. Os primeiros resíduos não biodegradáveis, produzidos pela humanidade, são os fragmentos deixados quando o homem das cavernas cozinhava sobre o fogo, e os cacos de utensílios de cerâmica utilizados para armazenar os excedentes da agricultura.

A Revolução Industrial, ocorrida a partir do final do século XVIII, trouxe uma forte apropriação da natureza, a produção de bens de consumo e a geração de resíduos com características diferentes daqueles produzidos anteriormente. Além disso, no início do século XX teve início a difusão de inovações de produtos e de processos. Os novos processos, baseados na mecanização do trabalho, linhas de 
montagem, parcelamento das tarefas e estandartização dos produtos finais, chamados de paradigma técnico-econômico fordista, pressupunham, para sua expansão, uma grande abundância de recursos naturais, principalmente de energia, na forma de hidrocarbonetos, surgindo a sociedade de consumo de massas (FURTADO 1991, p.16).

Nesse quadro, os resíduos gerados pela sociedade sofrem alterações quantitativas e qualitativas ao longo do tempo. Aos resíduos domésticos, que eram basicamente orgânicos, agregam-se as embalagens de papel, papelão, vidro, metal e, mais tarde, o plástico utilizadas para armazenar utilidades domésticas, facilitando o seu transporte das fontes produtoras ao consumidor final. Também surge uma variedade de resíduos industriais com características físicas e químicas que o ambiente não pode mais absorver. BUARQUE (1989) considera que a cadeia produtiva possui dois lados: o dos recursos naturais e o dos resíduos (que podem ser positivos, neutros ou perversos). O efeito ecológico perverso do primeiro é o esgotamento dos recursos da natureza necessários à vida, e o do segundo, a geração de poluentes ambientais prejudiciais à vida.

Enterrar o lixo, ou dispô-lo a céu aberto, preferencialmente, longe dos olhos da sociedade geradora, era a prática normal de sua destinação. Contudo, com o crescimento das cidades, novas tecnologias para tratamento e disposição do lixo urbano foram requeridas, como a incineração e os aterros sanitários. Vale lembrar que depositar os resíduos em lixões é uma prática que perdura até os dias de hoje em países em desenvolvimento, a exemplo do Brasil, onde 22,49\% do lixo coletado têm destinação sanitariamente incorreta ou seja, são lançados em cursos d'água ou a céu aberto IBGE (2000).

Nas décadas de 60/70, das rupturas ocorridas na economia mundial, destacase a ocorrida no plano energético, com o choque do petróleo, que interrompeu a trajetória de crescimento da economia mundial baseada no uso extensivo de recursos naturais. Também se torna visível o potencial de contaminação por parte das indústrias químicas, desencadeando diversos desastres ecológicos e a conseqüente identificação das denominadas áreas contaminadas. Essa problemática ambiental foi, segundo LEFF (2001), uma crise de civilização, questionando a racionalidade econômica e tecnológica dominante, explicada a partir de uma diversidade de 
perspectivas ideológicas: "por um lado é percebida como resultado da pressão exercida pelo crescimento da população sobre os limitados recursos do planeta, por outro, é interpretada como o efeito da acumulação de capital e da maximização da taxa de lucro a curto prazo, que induzem a padrões tecnológicos de uso e ritmos da exploração da natureza, bem como formas de consumo, que vêm esgotando as reservas de recursos naturais" (LEFF 2001, p. 59).

A crise civilizatória fez emergir, neste período, os movimentos ambientalistas, questionando o modo de vida da sociedade, e as conferências internacionais como fórum de discussão sobre a diversidade de perspectivas ideológicas responsáveis pela problemática ambiental.

A Conferência de Estocolmo sobre Meio Ambiente, em 1972, e a publicação do Relatório Limites para o Crescimento do Clube de Roma foram marcos importantes na tomada de consciência, no plano internacional, de que os recursos naturais eram limitados e, que por esta razão, aumentava a interdependência entre os diferentes países do planeta (FURTADO 1991, p.20).

Após a Conferência de Estocolmo, foram realizados outros eventos sobre a temática ambiental. Em 1982, foi criada a Comissão Mundial sobre Meio Ambiente e Desenvolvimento, responsável pela elaboração do Relatório Brundtland ou Relatório Nosso Futuro Comum e, em 1992, realizou-se a Conferência das Nações Unidas sobre o Meio Ambiente e Desenvolvimento, RIO’92. Nesses eventos, o foco das discussões foi direcionado para a forma de desenvolvimento adotado pelos diversos países, para o alto consumo de energia nos países desenvolvidos e para a pobreza nos países subdesenvolvidos. O termo desenvolvimento sustentável, cujo princípio básico é preservar os recursos existentes a fim de assegurar a satisfação das necessidades humanas às presentes e futuras gerações, foi a base para os diversos documentos e tratados elaborados nesses eventos. Um desses documentos é a Agenda 21 (1992), produto da RIO'92, composta por 40 capítulos, os quais tratam dos diversos aspectos sócio-econômicos e ambientais centrados no desenvolvimento sustentável, integrado nas políticas públicas e nas práticas sociais de todos os países do mundo. No capítulo 21, da Agenda 21, é tratada a questão dos resíduos sólidos, enfatizando que: 
“o manejo ambientalmente saudável dos resíduos sólidos deve ir além do simples depósito ou aproveitamento, por métodos seguros, dos resíduos gerados, e resolver a causa fundamental do problema, procurando mudar os padrões não sustentáveis de consumo. Isso implica na utilização do conceito de manejo integrado do ciclo vital, o qual apresenta oportunidade linica de conciliar o desenvolvimento com a proteção ambiental".

O manejo dos resíduos sólidos está fundamentado nos seguintes princípios: redução ao mínimo de resíduos (mudança dos padrões de produção e consumo); reutilização e reciclagem; promoção de disposição final; tratamento ambientalmente saudável dos resíduos; e ampliação do alcance dos serviços que se ocupam do gerenciamento dos resíduos.

Atualmente, o grande desafio que se coloca nesse campo é atingir as metas previstas pela Agenda 21: até o ano 2.025, os países em desenvolvimento deverão alcançar uma cobertura de tratamento e disposição final adequada para $100 \%$ dos resíduos gerados. Estima-se que, até lá, a população desses países esteja em torno de 6 bilhões de habitantes, estando dois terços deles vivendo em áreas urbanas e, no seu rastro, sendo gerados cerca de 6 milhões de toneladas de lixo por dia. O manejo desses resíduos não dependerá, exclusivamente, de técnicas apropriadas, mas de se repensar sobre a questão do lixo, encarando-o como um "resíduo positivo", que pode economizar os recursos da natureza por meio da minimização, da reciclagem e de um trabalho transdisciplinar de transformação da sociedade - de sociedade de consumo para uma sociedade sustentável - a qual

"produz o suficiente para si e para os seres dos ecossistemas onde ela se situa; que toma da natureza somente o que ela pode repor; que mostra um sentido de solidariedade, ao preservar para as sociedades futuras, os recursos naturais de que elas precisarão. Na prática, a sociedade deve mostrar-se capaz de assumir novos hábitos e de projetar um tipo de desenvolvimento que cultive o cuidado com os equilíbrios ecológicos e funcione dentro dos limites impostos pela natureza. Não significa voltar ao passado, mas oferecer um novo 
enfoque para o futuro comum. Não se trata, simplesmente, de não consumir, mas de consumir responsavelmente" (BOFF 1999, p.137).

Neste contexto, pergunta-se como a sociedade atual poderá incorporar os valores de solidariedade, de assumir novos hábitos como o de consumo responsável e de projetar e incorporar um outro tipo de desenvolvimento. Acredita-se que um dos caminhos seja através da Educação Ambiental, pela promoção da reflexão crítica sobre a problemática ambiental para a transformação dos sistemas que a sustentam.

Durante a $1^{a}$. Conferência Nacional de Educação Ambiental realizada em Brasília, em 1997, foi distribuído um documento contendo o Levantamento Nacional de Projetos de Educação Ambiental, no qual são apontados os principais temas geradores de projetos na área: problemas da realidade local e geral $(47,2 \%)$, lixo $(32,6 \%)$, ambiente urbano $(20,2 \%)$, ações comunitárias $(19,4 \%)$ e o contexto escolar $(45,1 \%)$ (CZAPSKI 1998, p.65). Observa-se que as questões relacionadas aos resíduos sólidos urbanos foram um dos grandes temas geradores de projeto, demonstrando a pertinência de realização de pesquisas para avaliar os programas de educação ambiental que enfocam tais questões. É o que se propõe no presente estudo, onde serão analisados três programas de Educação Ambiental que tiveram como foco os resíduos sólidos urbanos e conduzidos por diferentes setores da sociedade: universidade, associação comunitária e instituição governamental.

O primeiro programa realizado no campus da Universidade Estadual de Feira de Santana, Bahia, foi implantado em 1992 e coordenado pela Equipe de Educação Ambiental (EEA) dessa Universidade. O segundo está sendo desenvolvido no Arraial de São Francisco da Mombaça, distrito de Conceição do Almeida, Bahia, desde 1997, sendo conduzido pela Associação Comunitária local. Por último, o Programa de Educação Ambiental implementado no município de Mucugê, Bahia, para dar suporte à coleta seletiva e à Usina Simplificada de Reciclagem e Compostagem do Lixo da sede do município que foram implantadas em 2000. A condução das atividades de Educação Ambiental em Mucugê foi coordenada por técnicos da Companhia de Desenvolvimento e Ação Regional (CAR) órgão vinculado à então Secretaria do Planejamento, Ciência e Tecnologia do Governo do Estado da Bahia. 


\subsection{Sustentabilidade, Ambientalismo e Participação}

Os desastres ecológicos, a crise energética, a identificação de área contaminadas, as aglomerações urbanas, entre outros aspectos definidores da problemática ambiental, frutos da forma de desenvolvimento em curso (capitalistaindustrial), fizeram emergir o movimento ambientalista, responsável pela visibilidade, na esfera pública, dessas questões, e pelas discussões em torno da dependência entre desenvolvimento e meio ambiente em importantes conferências internacionais.

A Conferência das Nações Unidas sobre o Ambiente Humano ocorrida em Estocolmo em 1972, colocou a dimensão do meio ambiente na agenda internacional. Essa conferência foi precedida pelo encontro de Founex, em 1971, e, nesses eventos, foi se delineando a possibilidade de se "projetar e implementar estratégias adequadas para promover um desenvolvimento sócio-econômico eqüitativo, ou ecodesenvolvimento, uma expressão que foi, mais tarde, rebatizada como desenvolvimento sustentável" (SACHS 1993, p. 30). Esse novo desenvolvimento foi uma forma de contrabalançar as posições opostas existentes sobre esse tema: a dos otimistas, que previam a abundância dos recursos naturais do planeta e, das infinitas possibilidades da tecnologia, e a dos catastrofistas, preocupados com o crescimento demográfico, econômico e de consumo e com o esgotamento dos recursos naturais.

O Ecodesenvolvimento, segundo Sachs, é aquele desenvolvimento possível, guiado por soluções específicas para os problemas particulares encontrados em determinada região. O conceito de desenvolvimento sustentável surgiu do documento intitulado Nosso Futuro Comum (Comissão Mundial sobre Desenvolvimento e Meio Ambiente, 1988), também conhecido como Relatório Bruntland, que assim o define: "aquele que satisfaz as necessidades das gerações presentes, sem comprometer a capacidade das gerações futuras para satisfazer suas próprias necessidades".

Estes encontros foram seguidos por outros que culminaram na Conferência das Nações Unidas sobre Meio Ambiente e Desenvolvimento, realizada na cidade do Rio de Janeiro, em 1992. Nessa Conferência, "foi elaborado e aprovado um programa global para regulamentar o processo de desenvolvimento com base nos princípios da sustentabilidade, sendo prefigurada uma política para a mudança global 
que busca dissolver as contradições entre meio ambiente e desenvolvimento" (LEFF 2001, p. 20).

Os documentos resultantes dessas conferências foram decisivos para embasar a discussão sobre os limites ecológicos do crescimento econômico e sobre o questionamento da perpetuação do projeto de desenvolvimento capitalista convencional.

Inicialmente, SACHS (1993) classifica em cinco, as dimensões da sustentabilidade: social, econômica, ecológica, espacial e cultural. Através do desdobramento dessas dimensões, o mesmo autor, em artigo recente, considera como oito os pilares da sustentabilidade (SACHS 2000, p. 54). "Quer seja denominado ecodesenvolvimento ou desenvolvimento sustentável, a abordagem fundamentada nos objetivos sociais, ambientais e econômicos não se alterou desde o encontro de Estocolmo e é válida a recomendação da utilização dos oito critérios distintos de sustentabilidade", que são:

1. Sustentabilidade Social: que se entende como a distribuição de renda justa e igualdade no acesso aos recursos e serviços sociais reduzindo a pobreza e as desigualdades sociais e promovendo a justiça e a equidade;

2. Sustentabilidade Cultural: que prevê o equilíbrio entre o respeito à tradição e à inovação desenvolvendo a capacidade para elaboração de um projeto nacional integrado e endógeno. Esse pilar deve ser sustentável na conservação de um sistema de valores, de práticas e de símbolos de identidade;

3. Sustentabilidade Ecológica: que consiste na preservação do potencial do capital natural, por meio da produção de recursos renováveis e da limitação do uso dos recursos não renováveis;

4. Sustentabilidade Ambiental: que deve respeitar e realçar a capacidade de autodepuração dos ecossistemas naturais e preservar a biodiversidade;

5. Sustentabilidade Territorial: procura a melhoria do ambiente urbano com o emprego de estratégias de desenvolvimento ambientalmente seguras para áreas ecologicamente frágeis. Elaboração de projetos que respeitem as características urbanas e rurais locais e, também, busquem a superação das disparidades regionais;

6. Sustentabilidade Econômica: desenvolvimento econômico intersetorial equilibrado, segurança alimentar, capacidade de modernização contínua 
dos instrumentos de produção e razoável nível de autonomia na pesquisa científica e tecnológica;

7. Sustentabilidade da Política Nacional: democracia definida em termos de respeito universal dos direitos humanos, desenvolvimento da capacidade do Estado para implementar um projeto nacional, em parceria com todos os empreendedores, com razoável nível de coesão social;

8. Sustentabilidade da Política Internacional: eficácia do sistema de prevenção de guerras da Organização das Nações Unidas, na garantia da paz e na promoção da cooperação internacional; controle efetivo do sistema internacional financeiro e de negócios, e do princípio de precaução, na gestão do meio ambiente e dos recursos naturais; um pacote Norte-Sul de co-desenvolvimento, baseado no princípio da igualdade. Prevenção das mudanças globais negativas e proteção da diversidade biológica e cultural. Também um efetivo sistema internacional de cooperação científica e tecnológica, e a eliminação parcial do caráter de commodity da ciência e da tecnologia, considerando-a como propriedade da herança comum da humanidade.

Em termos políticos, GUIMARÃES (1998), acrescenta que o desenvolvimento é politicamente sustentável ao se aprofundar a democracia para garantir o acesso e a participação de todos na tomada de decisões públicas. $\mathrm{O}$ autor chama a atenção colocando para este novo estilo de desenvolvimento que deve ser norteado por uma nova ética de crescimento, na qual os objetivos econômicos do progresso se subordinam às leis de funcionamento dos sistemas naturais, ao respeito à dignidade humana e à melhoria da qualidade de vida das pessoas.

"Não obstante, antes que as estratégias do ecodesenvolvimento conseguissem vencer as barreiras da gestão setorializada do desenvolvimento, reverter os processos de planejamento centralizado e penetrar no domínio do conhecimento estabelecido, as próprias estratégias de resistência à mudança da ordem econômica foram dissolvendo o potencial crítico e transformador das práticas do ecodesenvolvimento. O discurso ambiental crítico do ecodesenvolvimento cai em desuso e é suplantado pelo discurso do "desenvolvimento sustentável" com o intuito de ecologizar a economia, eliminando a contradição entre crescimento econômico e preservação da natureza" (LEFF 2001, p. 18). Esse é o caso do discurso dos empresários e 
industriais que, fundado em instrumentos técnicos e econômicos como a normatização ambiental, a reciclagem industrial e o controle de emissões, visam à proteção ambiental e também ao equacionamento da questão econômica, isto é, não perder mercado.

A incorporação, pela sociedade, dos princípios da sustentabilidade é extremamente difícil, pois implica na absorção de valores e de princípios de solidariedade de caráter global, além da "análise racional, do pensamento sistêmico, da acumulação e da elaboração de dados, já que resulta das relações entre sistema socio-econômico geral e seus subsistemas locais" (GIULLIANI 1998, p. 8). Conforme o mesmo autor, a sustentabilidade necessita compatibilizar dimensões potencialmente antinômicas, entre elas: a) Desenvolvimento Sustentável deve ser, ao mesmo tempo, dinâmico e conservador, já que tem que desenvolver a sociedade e conservar os recursos naturais; não pode ser implementado por um simples conjunto de reformas técnicas e econômicas, mas comporta quase uma revolução que se fundamenta, não somente em iniciativas políticas, mas, sobretudo, em novas regras de convivência, novas normas, novos valores. Entretanto, é uma revolução longa, mais próxima de um processo evolutivo, já que normas e valores novos devem ser internalizados pelos atores; b) neste processo de internalização da nova moral, os atores têm que aprender a pensar no global e agir no local e, por isso, necessitam de conhecimento sobre a cultura de sua sociedade e de noções científicas sobre a natureza. Em suma, o desenvolvimento sustentável impõe escolhas sobre o que tem de mudar e o que deve ser mantido e, por isso, não pode ser o resultado de fórmulas pré-determinadas, não pode ser decretado. Só pode provir da mobilização e da participação da população, e os movimentos sociais têm um papel importante, tanto no processo que pensa tal forma de desenvolvimento, como no que o realiza (GIULLIANI 1998, p.8).

FRANCO (2000), apoiado nas teorias de MATURANA e VARELA (1995) e de CAPRA (1997), chama de "sustentabilidade" o resultado de um padrão de organização, observado, inicialmente, em ecossistemas e, posteriormente, de forma mais precisa nos sistemas moleculares vivos. Cita que as características que conferem sustentabilidade aos ecossistemas são: interdependência, parceria, reciclagem, flexibilidade e diversidade. Baseado nesses pressupostos, o autor supõe, 
então, que "comunidades humanas" que apresentem características análogas tenham mais chances de ser sustentáveis, e define "desenvolvimento sustentável aquele que leva à construção de comunidades humanas sustentáveis, ou seja, comunidades que buscam atingir um padrão de organização em rede, dotadas de características como, interdependência, reciclagem, parceria, flexibilidade e diversidade" (FRANCO 2000, p. 31).

A interdependência é relacionada com o padrão organizativo do tipo autopoiética. "A consciência de que uma perturbação que ocorra com um dos nós de uma rede pode ser amplificada por laços de realimentação, afetando a rede toda, é a base da consciência de comunidade". A interdependência, quer dizer, a consciência de que o sucesso de todos depende do sucesso de cada um e vice-versa. GONÇALVES (2001) considera como um dos princípios ético-filosóficos de uma sociedade sustentável "a prática que, feita por um, pode ser feita por todos. A sustentabilidade pressupõe equidade social".

Em relação à reciclagem, FRANCO (2000) sustenta que, no âmbito local, pode-se ter a visão de que padrões sustentáveis de produção e consumo devem ser cíclicos para serem sustentáveis, tendendo para um padrão de emissão zero de resíduos, em que os gerados por uma atividade produtiva se transformem em insumos para a atividade produtiva seguinte.

A formação de parceria dar-se-á pela formação de associações, com a finalidade de cooperação no âmbito da comunidade, pelo conhecimento das possibilidades e das necessidades uns dos outros. As parcerias serão entre múltiplos atores: governamentais, empresariais e sociais.

Finalmente, o autor afirma que "um sistema será sustentável na medida de sua flexibilidade e de sua diversidade. O papel da diversidade está estreitamente ligado à estrutura do sistema em rede. Um sistema diversificado será flexível, pois conterá muitas partes sobrepostas que podem, parcialmente, substituir umas às outras" (FRANCO 2000, p. 34).

Para DIEGUES (1996, p.25) o conceito de "Sociedades sustentáveis parece ser mais adequado que o de "desenvolvimento sustentável", na medida em que possibilita a cada uma delas definir seus padrões de produção e consumo, bem como o padrão de bem-estar a partir de sua cultura, de seu desenvolvimento histórico e de 
seu ambiente natural. Além disso, deixa-se de lado o padrão das sociedades industrializadas, enfatizando-se a possibilidade da existência de uma diversidade de sociedades sustentáveis, desde que pautadas pelos princípios básicos da sustentabilidade ecológica, econômica, social e política". Neste sentido, devem estar centradas em uma política social que, do ponto de vista da sociedade, é a conquista da autopromoção, tendo o seu eixo político centrado na participação social. Conforme DEMO (1999), é por meio da participação que "promoção se torna autopromoção, projeto próprio, forma de co-gestão e autogestão e possibilidade de auto-sustentação". Assim, a participação da comunidade é um processo de conquista de si mesma, existindo na medida de sua própria conquista. Então, no conceito de desenvolvimento, a participação é o elemento qualitativo que diferencia o crescimento do desenvolvimento. Porque o crescimento é um fenômeno apenas econômico, enquanto que desenvolvimento seria o crescimento comprometido com o social.

O mesmo autor aponta alguns instrumentos de participação sistematizados em cinco canais: organização da sociedade civil, planejamento participativo, acesso universalizado a um mínimo de educação formal, questão cultural como formação histórica da identidade comunitária, e por último, o processo de conquista de direitos. Também, SAWAIA (2001), quando se refere à participação considera que participar é estar se posicionando sobre a concepção da sociedade, a respeito de cidadania, de ética, de justiça, de educação popular e de movimentos sociais contra desigualdades e exclusão social. Também poderia se considerar a Educação Ambiental como uma proposta política de reflexão, de debate e de posicionamento sobre a relação homemnatureza.

A organização da sociedade civil é estabelecida pela reunião de atores que, com, ou sem institucionalidade própria, trabalham questões específicas de seu entorno, ou que se agrupam em defesa de questões como gênero, negro, direitos humanos, meio ambiente ou que levam em conta interesses de uma categoria específica.

A sociedade pode se organizar de várias formas, sendo mais freqüente pelo associativismo civil, ou por meio dos movimentos sociais. No associativismo civil, encontram-se as Associações Comunitárias, Associações de Classe, Organizações de 
Defesa da Cidadania, Organizações Não Govenamentais, Mútua Ajuda e Associativismo de Base Religiosa. Enquanto o Associativismo Civil se identifica em torno de propostas comuns, os movimentos socais transcendem a prática localizada e temporal de uma organização. As práticas sócio-política-culturais são mais abrangentes, resultantes de múltiplas redes de relações sociais entre sujeitos e associações civis, que visam à realização de um projeto de mudança social. É através dos movimentos sociais que os sujeitos coletivos poderão começar a minar as tradicionais estruturas de dominação com seus respectivos modelos de desenvolvimento de exclusão social, de discriminação sociocultural e poderão estabelecer novos rumos para a nossa sociedade, com vistas às gerações futuras (SCHERER-WARREN 2001, p. 45).

VIOLA (1992) denomina de sócio-ambientalistas aos movimentos sociais influenciados pelo ambientalismo. Considera que, além do sócio-ambientalismo, a partir da segunda metade da década de 1980, outros setores da sociedade passaram a constituir o ambientalismo: associações e grupos comunitários ambientalistas; grupos e instituições científicas que realizam pesquisas sobre a problemática ambiental; empresários que começam a pautar seus processos produtivos e investimentos pelo critério da sustentabilidade ambiental; agências estatais do meio ambiente nos três níveis do Estado; educadores, artistas, jornalistas preocupados com a problemática ambiental e com capacidade de influenciar grande parcela da sociedade; religiosos que vinculam a problemática ambiental à consciência do sagrado e do divino; políticos profissionais que incentivam a criação de políticas específicas, e trabalham para incorporar a dimensão ambiental no conjunto das políticas públicas.

O ambientalismo, como movimento social, tem a potencialidade "de mobilização coletiva capaz de reiventar a sociedade e a vida política", e surgiu "como construtor de significações que dão sentido à vida, o sentido do que seja natureza, do que sejam necessidades" (GONÇALVES 2001).

CARVALHO (2001) define "ambientalismo e ambientalistas" como um conjunto mais amplo de movimentos e atores que, na esfera de difusão do ecologismo, aderem a um ideário de preservação e gestão sustentável do meio ambiente. E, conforme LEFF (2001, p103), “o ambientalismo é um movimento pela diversificação das condições de existência e dos projetos de vida dos povos, que se 
projeta da heterogênese do mundo para uma diversidade de tipos de desenvolvimento. É uma utopia que mobiliza a ação para a construção de uma nova racionalidade produtiva e um projeto alternativo de civilização".

Neste sentido, o ambientalismo é um espaço de participação e atuação da cidadania e, segundo VIOLA (1992), a participação autêntica "começaria com um processo endógeno de identificação de problemas e necessidades" que seria, então, o segundo canal de participação: o planejamento participativo. Porque "a percepção da problemática ambiental não é homogênea e cobre um amplo espectro de concepções e estratégias de solução e depende do contexto geográfico, cultural, econômico e político das forças sociais e de potenciais ecológicos amparados por estratégias teóricas e produtivas diferenciadas" (LEFF 2001, p. 96). A exemplo dos movimentos sociais que trabalham com enfoque diferenciados, como diferem entre si as demandas sociais e ambientais dos países desenvolvidos e subdesenvolvidos. Enquanto nos primeiros, são privilegiadas a conservação da natureza e a remediação dos efeitos contaminantes dos processos de produção, com preocupações ambientais centradas na mudança climática, efeito estufa, perda da biodiversidade, nos segundos, são enfatizadas as mudanças sociais, políticas e institucionais necessárias para o aproveitamento racional dos recursos existentes e do potencial produtivo local para a satisfação das necessidades básicas da população. São importantes também, nesses países, principalmente nas zonas periféricas de grandes cidades e em pequenas comunidades, o enfrentamento de problemas como o saneamento ambiental, e a incidência de doenças com ele relacionadas, o baixo nível educacional e de qualificação profissional, a pobreza, os espaços urbanos degradados e o uso dos recursos naturais para sobrevivência.

Finalmente, pode-se dizer que os movimentos sociais e o ambientalismo em particular, o conhecimento local e a participação da sociedade têm papel importante na transformação do desenvolvimento pautado na equidade social que atenda aos princípios de sustentabilidade ambiental, econômica, social e política. A Educação Ambiental, como prática política, pode ser um instrumento importante nessa transformação. "A validação da Educação Ambiental dá-se sobretudo pelo reconhecimento da problemática ambiental na esfera pública e pela força dos atores que são seus porta vozes" (CARVALHO 2001, p 260). 


\section{O papel da Universidade}

Algumas Universidades e Movimentos Sociais (entidades ambientalistas, sindicatos, associações de classe e de moradores), por meio de atividades de Educação Ambiental, têm influenciado as comunidades nas mudanças de atitudes em relação aos seus problemas locais, sendo a questão dos resíduos sólidos urbanos um dos temas freqüentemente demandados pela sociedade.

A Universidade é responsável pela produção e transmissão do conhecimento, pela formação de profissionais qualificados, pela pesquisa científica, pelo incentivo à cultura da sociedade e, também, participante da resolução de problemas que se apresentam na sociedade.

Como já referenciado por SCHERER-WARREN (2001), as Universidades podem ser uma das participantes das redes de relações sociais entre sujeitos e associações civis, que visam à realização de um projeto de mudança social. Neste sentido, as práticas sócio-políticas-culturais devem estar presentes nas Universidades e as atividades de extensão universitária têm um papel significativo na interação destas com a comunidade.

Conforme THIOLLENT (1996), a extensão universitária deve ir além da extensão "assistencialista" que é muitas vezes destinada a populações especialmente carentes no que diz respeito a questões de moradia e saúde e, além da extensão "empresarial" que é a prestação de serviços externos. A extensão deve-se posicionar em torno de projetos elaborados em parceria com os interessados (municípios, empresas, associações). Dessa maneira, a extensão deixaria de ser assistencialista pois se realizaria em função de demandas manifestadas e não de oferta unilateral. Por exemplo, o contato com o município é útil no contexto do desenvolvimento regional, local, urbano ou rural como também no contexto ambiental, social ou educacional. $\mathrm{O}$ contato com sindicatos e associações é indispensável para apreender a capacidade de mudança.

THIOLLENT (1996) e VIEIRA (1995) ressaltam que a extensão universitária proporciona a utilização da pesquisa - ação que se desenvolverá interagindo com a ação ou com a prática dos interessados, favorecendo a interação politicamente eficaz entre a esfera da pesquisa científica e a esfera da ação planejadora de corte 
participativo. E neste contexto, possibilita o desenvolvimento de projetos interdisciplinares "orientado por um objetivo prático, comum a diferentes campos de saber" (LEFF 2001, p. 81) tão necessário para encarar os problemas locais.

Portanto, as Universidades devem abrir-se a um processo de pesquisa em conjunto com comunidades e populações nas quais existem os problemas ambientais, captando-os partir das bases (LEFF 2001). 


\title{
1.3 A Educação Ambiental
}

\begin{abstract}
“La revolución copérnica nos reveló que el Sol no gira alredor de la Tierra. El siglo XXI que se anuncia nos antecipa que la Tierra no gira alrededor de los seres humanos y que, cuando éstos han actuado como si así fuese, la ecosfera les há devuelto multiplicados los rutos de suas acciones" (NOVO 1996, p.22)
\end{abstract}

No período de 1971/1980, com a realização de diversas conferências sobre meio ambiente, o tema Educação Ambiental também começou a aparecer em vários relatórios e programas gerados nesses fóruns.

O Seminário Internacional de Educação Ambiental realizado em outubro de 1975, em Belgrado, fixou como metas ambientais: "Melhorar as relações ecológicas, incluindo as do homem com a Natureza e as dos homens entre si", e como metas da Educação Ambiental: "Lograr que a população mundial tenha consciência do meio ambiente e se interesse por ele e por seus problemas conexos e que conte com os conhecimentos, atitudes, motivações e desejos necessários para trabalhar individual e coletivamente na busca de soluções dos atuais problemas e para prevenir os que podem aparecer no futuro". Os objetivos traçados para a Educação Ambiental são: consciência, conhecimento, atitudes, aptidão, capacidade de avaliação e participação.

A Conferência Intergovernamental de Educação Ambiental ocorrida em 1977, em Tbilisi, é considerada um marco significativo na história da Educação Ambiental ao estabelecer como seus objetivos fundamentais: levar os indivíduos e a coletividade a compreender seu ambiente natural e o ambiente construído pelo homem (tecnológico, social, econômico, político, histórico-cultural, moral e estético), bem como incentivá-los na aquisição de conhecimentos, valores, comportamentos e habilidades práticas para participar da prevenção e da solução da gestão ambiental. Para isto, a Educação Ambiental deve suscitar uma vinculação estreita entre os processos educativos e a realidade, estruturando suas atividades em torno dos problemas concretos que se impõem à comunidade. Recomenda, ainda, que 
a Educação Ambiental seja um processo contínuo, interdisciplinar e dirigido a toda a sociedade, vinculado à legislação e às políticas ambientais (DIAS 1992). SORRENTINO (1995) destaca, da declaração final da Conferência de Tbilisi, que "a Educação Ambiental deve orientar-se para a comunidade. Deve motivar os indivíduos em um processo ativo para resolver problemas no contexto de realidades específicas e deve fomentar a iniciativa, o sentido de responsabilidade e o empenho em edificar um amanhã melhor. Por sua própria natureza, a Educação Ambiental pode contribuir efetivamente para renovar o processo educativo".

Em Moscou, no ano de 1987, durante o Congresso Internacional de Educação Ambiental, um dos acordos finais resultantes foi a declaração de serem os anos 90 a “década mundial para a Educação Ambiental", estabelecendo que os programas a serem desenvolvidos neste período, deveriam dar ênfase às relações entre a humanidade e a biosfera, em suas manifestações: econômicas, sociais, políticas e ecológicas. Convém destacar a afirmação de que "não é possível definir as finalidades da Educação Ambiental sem ter em conta as realidades econômicas, sociais e ecológicas de cada sociedade e os objetivos determinados para o seu desenvolvimento". Segundo NOVO (1996), essa afirmativa reflete a influência do Relatório Brundtland, que enfatiza os vínculos existentes entre os modelos de desenvolvimento e a problemática ambiental, influenciando os trabalhos em Educação Ambiental que destacam o desenvolvimento sustentável.

A Agenda 21 (1992), produto da Conferência das Nações Unidas sobre Meio Ambiente e Desenvolvimento, comumente denominada de Rio-92, em seu capítulo 36, refere-se ao incentivo à educação e à capacitação na tomada de consciência, sendo três as áreas de programas descritas neste capítulo: reorientação do ensino, no sentido do desenvolvimento sustentável; aumento da consciência pública; a promoção e o treinamento. $\mathrm{O}$ documento reconhece que o ensino, tanto formal como informal, tem fundamental importância para o desenvolvimento sustentável e que é básico para conferir consciência ambiental e ética, valores e atitudes, técnicas e comportamentos em consonância com tal desenvolvimento.

Se a Conferência de Tbilisi é considerada um marco para a Educação Ambiental, por estabelecer critérios que inspiraram o movimento educativo nas décadas seguintes, foi o Tratado de Educação Ambiental para Sociedades 
Sustentáveis o "divisor de águas", ao pensar a Educação Ambiental como um ato político voltado para a transformação social e para a formação de um tipo de sociedade (sustentável) baseada na eqüidade e no equilíbrio ecológico. "A Educação Ambiental não é neutra, mas ideológica. É um ato político baseado em valores para a transformação social" (princípio 4 do referido tratado). Também, a Educação Ambiental deve estimular e potencializar o poder das diversas populações, conscientizando as comunidades de que devem retomar a condução de seus próprios destinos. Considera que a Educação Ambiental é um processo de aprendizagem permanente, baseado no respeito a todas as formas de vida, e deve estimular a formação de sociedades socialmente justas e ecologicamente equilibradas, que conservem entre si relação de interdependência e diversidade.

Do seu plano de ação, pode ser destacado que a Educação Ambiental deve:

$>$ Incentivar à produção de conhecimentos, políticas, metodologias e práticas de Educação Ambiental em todos os espaços de educação formal, informal e não formal, para todas as faixas etárias;

$>$ Promover e apoiar à capacitação de recursos humanos para preservar, conservar e gerenciar o ambiente, como parte do exercício da cidadania local e planetária;

$>$ Promover a compreensão das causas dos hábitos consumistas, e a ação para a transformação, não só dos sistemas que os sustentam, como também de nossas próprias práticas;

$>$ Fortalecer as organizações e movimentos sociais como espaços privilegiados para o exercício da cidadania e melhoria da qualidade de vida e do ambiente.

A declaração final da Conferência Internacional em Ambiente e Sociedade: Educação e Conscientização para a Sustentabilidade, realizada no ano de 1997, em Tessalonik, Grécia, valida as recomendações e planos de ação dos eventos realizados anteriormente. Afirma que, para atingir a sustentabilidade, deve haver uma coordenação e integração de esforços em diversos setores, e uma mudança rápida e radical de comportamento e estilos de vida, quanto ao padrão de consumo e produção. Para isso, uma educação apropriada e uma conscientização pública devem ser consideradas como os pilares da sustentabilidade, juntamente com a legislação, 
economia e tecnologia. A educação formal e a informal devem ser reorientadas com vistas à sustentabilidade que compreende, além do ambiente, a pobreza, a população, a saúde, a segurança alimentar, a democracia, os direitos humanos e a paz. A sustentabilidade é um imperativo moral e ético no qual a diversidade cultural e o conhecimento tradicional precisam ser respeitados. Essa conferência não trouxe novidades em relação aos eventos anteriores, destacando-se, dentre as considerações citadas por SORRENTINO (2000), que o evento reforçou a necessidade de formação de professores e apontou a carência de material didático e a ausência de discussões metodológicas e pedagógicas sobre o tema.

No Brasil, a partir de 1999, foi definida a Política de Educação Ambiental (PNEA), pela Lei Federal N. 9.795 (BRASIL 1999). Essa lei define a Educação Ambiental como os processos por meio dos quais o indivíduo e a coletividade constroem valores sociais, conhecimentos, habilidades, atitudes e competências voltadas para a conservação e sustentabilidade do meio ambiente - bem de uso comum do povo, essencial à sadia qualidade de vida.

VELASCO (2002) destacando alguns tópicos sobre o perfil da PNEA, comenta que a lei consegue dar uma idéia geral mais que disciplinar da pretensão da Educação Ambiental, quando, no seu Artigo 10, estipula que esta será desenvolvida como uma prática educativa integrada, contínua e permanente em todos os níveis e modalidade de ensino formal. Na educação formal, a PNEA, prevê a inclusão da Educação Ambiental, não como uma disciplina, mas como forma de integrar todas as disciplinas. O autor considera um equívoco a proibição da criação de uma disciplina de Educação Ambiental em outro espaço que não seja o dos cursos de pósgraduação, e defende que a PNEA deveria limitar-se a "aconselhar" a não criação da disciplina, pois, "na presença de omissões e resistências, é melhor ter-se, pelo menos, um espaço garantido de Educação Ambiental na forma de uma disciplina, que não se ter nada em absoluto". Com esse ponto, SORRENTINO (1999) concorda, ao afirmar que "da mesma forma que eu era contrário à criação de uma disciplina obrigatória de Educação Ambiental na rede escolar, também sou contrário a sua proibição" [Anonymus, 1999].

VELASCO (2002) também considera que há uma incógnita na PNEA quanto a sua implementação, em especial, no que diz respeito aos recursos disponíveis para 
sua efetivação, e à cobrança das responsabilidades a ela atribuídas, incluindo o funcionamento do Órgão Gestor previsto na lei. E recomenda, que neste contexto, "ganha importância a idéia de se criarem espaços para os quais todos os projetos e as ações de Educação Ambiental possam convergir não só para o salutar intercâmbio cooperativo que a todos enriquece, como também para a soma de forças com vistas à luta pela obtenção de recursos".

\subsubsection{Educação Ambiental e sustentabilidade}

Durante esses últimos trinta anos, as definições e os planos de ação em Educação Ambiental sofreram variações, sendo essas influenciadas pelas discussões e recomendações dos eventos sobre o tema, pelo contexto local (países ricos e pobres) e pela relação do homem com a natureza. Conforme DIAS (1992, p.25), “a evolução dos conceitos de EA tem sido vinculada ao conceito de meio ambiente e ao modo como este é percebido. O conceito de meio ambiente reduzido exclusivamente a seus aspectos naturais não permitia apreciar as interdependências, nem a contribuição das ciências sociais à compreensão e melhoria do ambiente humano".

Neste sentido, a definição de Educação Ambiental é uma tarefa complexa. SORRENTINO (1995) classifica, tanto teórica como prática, em quatro as correntes de Educação Ambiental: conservacionista, ao ar livre, gestão ambiental e economia ecológica.

A primeira corrente, conservacionista, presente nos países mais desenvolvidos, ganha grande impulso com a divulgação dos impactos causados sobre a natureza, pelo modelo de desenvolvimento em curso.

A Educação ao ar livre está presente nos trabalhos de naturalistas, como escoteiros, espeleólogos, adeptos do montanhismo, nos trabalhos de Educação Ambiental, como as "caminhadas ecológicas" e as "trilhas de interpretação da natureza", além naqueles que pregam o contato com a natureza para o auto conhecimento. As "trilhas de interpretação", utilizadas como recurso educativo em parques naturais, reservas florestais, conforme CARVALHO (2001), "ilustram uma Educação Ambiental fortemente marcada pela tradição explicativa das ciências naturais". 
A terceira corrente, gestão ambiental, tem raízes mais profundas nos movimentos sociais da América Latina e reivindica a participação da população na administração dos espaços públicos, e nas definições do futuro, tendo forte implicação política. Essa corrente critica o modelo capitalista predador da natureza.

Por último, a categoria denominada por SORRENTINO (1995) de "economia ecológica", inspirada no conceito de ecodesenvolvimento formulado por SACHS (1986) e SHUMACHER (1983). Esses conceitos, desenvolvidos na década de 70, ganharam impulso, na metade da década de 80 , por parte dos organismos internacionais e de bancos multilaterais. Também estão incluídas nesta corrente ONGs, comunidades rurais que pregam, entre outras coisas, o uso de tecnologias alternativas na agricultura, na geração de energia e no tratamento de resíduos. Essa quarta corrente, segundo o mesmo autor, desdobra-se em outras duas: "desenvolvimento sustentável" e "sociedades sustentáveis". A primeira, aglutinando empresários, governantes e uma parcela das organizações não governamentais, e a segunda, reunindo aqueles que sempre estiveram na oposição ao atual modelo de desenvolvimento, e que acreditam que a primeira corrente é só uma roupagem para a manutenção do "status quo". Segundo o mesmo autor, essas vertentes foram a tônica do movimento ambientalista do final do século XX.

CRESPO (1997) apresenta algumas práticas de Educação Ambiental: Educação Ambiental orientada para a mudança de comportamento, para a mudança de sensibilidade e para a sustentabilidade.

A primeira prática, que a autora também chama de Educação Ambiental para a mudança de comportamento ou de resultados, é caracterizada "pela relação direta entre a informação e a mudança de comportamento. Pressupõe que os indivíduos devidamente informados sobre as consequiências danosas ou letais dos seus atos, e dominando corretamente os conceitos necessários à compreensão das relações entre o processo natural e social, estão prontos para transformar hábitos e atitudes”. Essa prática de Educação Ambiental é realizada freqüentemente, segundo a autora, por agências governamentais e por escolas onde o modelo tecnicista prevalece.

A segunda prática, Educação Ambiental orientada para a mudança de sensibilidade, pressupõe que a conscientização é um processo que passa pela construção de uma nova sensibilidade. Ao questionar os fundamentos do modo de 
vida da humanidade, promove o pensamento sistêmico e uma abordagem holística dos problemas. No processo educativo, são valorizados a razão intuitiva e o imaginário, o ouvido poético. Valoriza o estudo do entorno e a experiência dos grupos e das comunidades. Essa tendência é praticada, sobretudo, por organizações não-governamentais ambientalistas e comunitárias.

A dimensão da sensibilidade, segundo GONÇALVES (2001), "é uma das mais importantes no debate da questão ambiental. Isto porque, além de romper a razão utilitarista-instrumental, precisa do lugar onde se realiza a vida coletiva do dia a dia, lugar da vizinhança, da coabitação, da coexistência do diverso". A sensibilidade "recoloca a natureza como lugar do sem-sentido, do que brota por si mesmo, nasce, natura, do que não foi feito por nós humanos e, assim, é a dimensão do nosso limite".

A Educação Ambiental para a sustentabilidade, como a terceira prática citada por CRESPO (1997), está baseada nos valores que a Agenda 21 promove. Um desses valores é a cooperação entre países, através do governo, e entre diferentes segmentos e atores sociais, incluindo-se a solidariedade e a parceria. O segundo valor é a igualdade de direitos e o fortalecimento dos grupos socialmente vulneráveis, incluídos, nesses, crianças, jovens, idosos, deficientes, mulheres, populações tradicionais e indígenas, buscando, para esses segmentos, além da igualdade de direitos e de participação, a contribuição de seus valores, conhecimento e sensibilidade.

O terceiro valor é a promoção da democracia e estímulo à participação de todos, pelo emprego de metodologias próprias, na negociação de conflitos e na implementação dos programas de desenvolvimento.

As distintas vertentes da sustentabilidade terão, pois, importante repercussão sobre as estratégias e conteúdos da Educação Ambiental. Os efeitos sobre o processo educacional serão diferentes se a transição privilegiar os mecanismos do mercado que valorizem a natureza, estimulando mudanças tecnológicas que desmaterializem a produção e limpem o ambiente, firmando-se uma nova ética e na construção de uma racionalidade ambiental (LEFF 2001, p. 248).

A grande questão que se coloca é como definir sustentabilidade "uma vez que o modelo histórico-civilizatório presente não tem a mínima possibilidade de ser 
o futuro da humanidade" GONÇALVES, (2001). Para a transformação do futuro da humanidade conforme, TASSARA (2001), deve-se incorporar a utopia no comportamento "através da indicação de como é possível se pensar no futuro pela construção do presente imediato.... e a participação seria uma condição para tal definição do futuro". Desse modo, a Educação Ambiental, como estimuladora da consciência crítica sobre a problemática ambiental, e da participação, visando a uma mudança de sensibilidades, suscita a busca de soluções criativas diferentes, da ótica do paradigma desenvolvimentista dominante. 


\subsubsection{Avaliação de Programas de Educação Ambiental voltados para os Resíduos Sólidos Urbanos}

Considerando a forte interdependência entre o gerenciamento sustentável dos resíduos sólidos urbanos e a participação da comunidade neste processo surgem os seguintes questionamentos: Até que ponto os programas de Educação Ambiental têm contribuído para formar uma consciência ambiental que faça emergir, da comunidade, a necessidade da sustentabilidade do manejo de resíduos sólidos urbanos? Como'se processa, no indivíduo, a mudança com relação à forma de perceber o seu lixo? Que variáveis interferem no processo dessa mudança? O que determina a descontinuidade dos projetos de coleta seletiva de resíduos sólidos urbanos?

No Brasil, experiências de manejo sustentado de resíduos sólidos, diferentes das tradicionais - coletar e depositar no solo - estão em andamento, a exemplo das realizadas no campus da Universidade Estadual de Feira de Santana, no Arraial de São Francisco da Mombaça, distrito de Conceição do Almeida/BA, que tem a participação da Equipe de Educação Ambiental dessa Universidade (EEA/UEFS), e no município de Mucugê/BA, onde foi implantada a coleta seletiva e a compostagem de tais resíduos sólidos.

Conhecer e avaliar os Programas de Educação Ambiental voltados para o gerenciamento sustentável dos resíduos sólidos, a partir da percepção dos indivíduos dessas comunidades, é um caminho que possibilitará responder àqueles questionamentos.

Uma das formas de avaliar a participação da comunidade em programas de coleta seletiva de lixo é observar a quantidade dos resíduos que chegam separados ao seu destino. Pela pesagem individual de cada componente do lixo, obtêm-se as proporções dos que estão efetivamente separados e possíveis de serem reciclados. Esse dado, embora válido para o acompanhamento da coleta seletiva dos resíduos ao longo do tempo, não indica as motivações que levaram os indivíduos a ter essa atitude. Segundo QUINTAS (2000), os programas de Educação Ambiental, que têm como eixo a questão do lixo, podem ser trabalhados de duas formas. A primeira, por meio da contestação do consumismo e do desperdício, com ênfase na ação 
individual. Neste quadro, a Educação Ambiental estaria promovendo a "mudança de comportamento do sujeito em sua relação, cotidiana e individualizada, com o meio ambiente e com os recursos naturais, objetivando a formação de hábitos ambientalmente responsáveis no meio social" (QUINTAS 2000, p. 15). A segunda forma trabalha a problemática do lixo como conseqüência da relação sociedadenatureza, histórica e socialmente construída, as causas de sua existência, e como os resíduos circulam no meio ambiente, havendo, assim uma construção coletiva no modo de compreendê-la e superá-la. Desta forma, instiga-se a "leitura da problemática ambiental sob a ótica da complexidade do meio social, e o processo educativo é pautado por uma postura dialógica, problematizadora e comprometida com transformações estruturais da sociedade, de cunho emancipatório" (ibid). No primeiro caso, "a transformação da sociedade seria o resultado da transformação individual dos seus integrantes" enquanto, no segundo, "ao participar do processo coletivo de transformação da sociedade, a pessoa também, estará se transformando" (ibid).

Já foi dito que os objetivos fundamentais da Educação Ambiental são os de levar às pessoas informações que estimulem a tomada de consciência, e ao desenvolvimento de atitudes e comportamentos para que possam participar, ativa e positivamente, no seu entorno. Conforme SORRENTINO (1995), "a Educação Ambiental deve contribuir para a conservação/proteção do Planeta e de todas as suas espécies, e para a melhoria da qualidade de vida de cada indivíduo e de cada comunidade, por meio de processos educativos instigantes, interativos, holísticos e que resgatem a capacidade de auto conhecimento e de auto-gestão política e econômica" e deve "promover a interdisciplinaridade, a visão crítica e global/holística, a participação e a interação, o auto conhecimento, o resgate de saberes e a resolução de problemas, tendo como conteúdos os problemas ambientais e de qualidade de vida considerados relevantes para os grupos envolvidos". Se o conteúdo do problema considerado relevante é a questão do lixo, as atitudes ambientais dos seres humanos em relação a esta, devem refletir sobre assuntos que vão além do ato de separar resíduos. É um profundo exercício crítico a cerca dos valores que intervêm como suporte em sua ação. Portanto, "a avaliação deve ser guiada pelas possibilidades que os membros envolvidos no objeto de avaliação têm 
de manifestar o seu ponto de vista, de se formarem e de se organizarem solidamente" (DEMO 1987, p.11).

A avaliação poderá ser feita, então, a partir das representações sociais dos atores das comunidades onde estão sendo desenvolvidos os programas de Educação Ambiental. Segundo Jodelet (1989), citada por GUARESCHI (1998, p.202), a representação social pode ser definida "como uma forma de conhecimento, socialmente elaborada e partilhada, tendo uma visão prática, e concorrendo para a construção de uma realidade comum a um conjunto social" e esta "deve ser reservada para aquela modalidade de conhecimento particular que tem por função a elaboração de comportamentos e a comunicação entre indivíduos" no quadro da vida cotidiana, conforme Moscovici, citado por SÁ (1996, p.43). Segundo esse mesmo autor, o mais importante, na representação social, é que ela "produz e determina comportamentos, visto que define, ao mesmo tempo, a natureza dos estímulos que nos envolvem e nos provocam e a significação das respostas a lhe dar" (ibid.). O estímulo proporcionado pela Educação Ambiental dá-se por meio dos recursos utilizados na sensibilização, na mobilização comunitária e no diálogo, suscitando, no público alvo, "uma leitura reflexiva, crítica do entorno, conduzindo-os à elaboração de seu próprio sistema de valores" (NOVO 1996, p.103).

Nos diversos eventos sobre Educação Ambiental, observa-se que suas metas gerais podem ser agrupadas em quatro categorias fundamentais, de acordo com CASTRO (1998, p. 338) e SORRENTINO (1995):

1. Ajudar na compreensão das dinâmicas ambientais e na análise crítica de sua relação com a ação humana e com os sistemas sociais;

2. Promover a interdisciplinaridade e o desenvolvimento de atitudes e valores sociais em favor da conservação/proteção do ambiente;

3. Possibilitar o desenvolvimento de comportamentos individuais e coletivos orientados para o resgate de saberes e para a resolução de problemas ambientais e de qualidade de vida, considerados relevantes para os grupos envolvidos;

4. Promover a visão crítica e global/holística, a participação, a interação e o auto conhecimento.

Portanto, para orientar a pesquisa formulou-se a seguinte hipótese: 
A continuidade de projetos de Gerenciamento de Resíduos Sólidos Urbanos requer programas de Educação Ambiental que contemplem, além de informações sobre a coleta seletiva, metodologias participativas e promovam parcerias, instigando a leitura e a resolução de problemas locais.

Neste contexto, a avaliação de programas de Educação Ambiental através da representação social, deverá buscar, nas falas dos indivíduos e nos documentos escritos sobre os programas, questões que envolvam:

A construção do conhecimento: instrumentos utilizados nos programas de Educação Ambiental para formação, capacitação, informação e comunicação. Condições físicas para a participação ou conforme SORRENTINO (2000), a infraestrutura para a participação. Nível de conhecimento sobre o programa, aspectos relevantes e negativos, e dificuldades encontradas durante o desenvolvimento do projeto;

O desenvolvimento de valores e atitudes: a ligação dos atores com a localidade em estudo, problemas ambientais locais e a inserção da questão dos resíduos sólidos nessa problemática. Observações sobre mudanças proporcionadas pelo projeto, tanto individual como na localidade em estudo. A definição de lixo dada pelas pessoas. Sentimentos e atitudes individuais em relação ao lixo. Percepção do público em relação à problemática do lixo com o processo histórico e social;

O comportamento e a ação: observar qual o nível de participação nas atividades do programa, a existência de espaço de locução, a forma de ação (direta ou indireta) na resolução do problema e o fortalecimento de grupos locais. 


\subsection{RESÍDUOS SÓLIDOS}

\subsubsection{Definição}

Segundo o dicionário Michaelis, "lixo" é aquilo que se varre do ambiente para torná-lo limpo, é imundície, enquanto que "resíduo" é tudo aquilo que resta, restante. A NBR 10.004 (ABNT, 1987) define resíduos sólidos e semi-sólidos como aqueles que resultam de atividades de comunidade de origem industrial, doméstica, hospitalar, comercial, agrícola, serviços e de varrição de vias e logradouros públicos. São incluídos também como resíduos sólidos, os lodos provenientes de sistemas de tratamento de água, resíduos gerados em equipamentos e instalações de controle de poluição, bem como determinados líquidos cujas peculiaridades tornem inviável seu lançamento na rede pública de esgotos ou em corpos de água, ou que exijam, para isso, soluções técnicas e economicamente inviáveis face à melhor tecnologia disponível. Segundo publicação IPT/CEMPRE (2000), "lixo é o resto das atividades humanas, considerado pelos geradores como inútil, indesejável ou descartável". Atualmente, no meio técnico voltado para essa questão, há uma preferência pelo termo resíduo sólido. Acredita-se que seja pelo fato de o termo "lixo" ter uma conotação de imundície e de repulsa e, também, porque, na massa de lixo, ainda podem ser encontrados materiais que tenham utilidade para outros e ser matéria prima para a indústria de reciclagem. Neste trabalho, serão utilizados os dois termos com o mesmo significado, referindo-se a todo material considerado sem utilidade e descartado pela pessoa que o tenha gerado.

\subsubsection{Classificação dos Resíduos Sólidos}

A NBR 10.004 (ABNT 1987) classifica os resíduos em três classes distintas, a saber:

Os resíduos classe I, denominados de Resíduos Perigosos são aqueles que apresentam periculosidade, isto é, risco à saúde pública - provocando ou acentuando, de forma significativa, um aumento de mortalidade ou incidência de doenças - ou ao 
meio ambiente, quando manuseados ou destinados de forma incorreta. Também são considerados como classe I os resíduos que apresentam uma das seguintes características: inflamabilidade, corrosividade, reatividade, toxicidade patogenicidade.

Os resíduos que pertencem à classe II são denominados de Não Inertes e não se enquadram na classe I ou na classe III. Esses resíduos têm propriedades como: combustibilidade, biodegrabilidade e solubilidade em água.

Os resíduos classe III, denominados de Resíduos Inertes, referem-se àqueles que, em contato (estático ou dinâmico) com água destilada, em temperatura ambiente, não tenham nenhum de seus constituintes solubilizados, a concentrações superiores aos padrões de potabilidade da água, excetuando-se os padrões de cor, turbidez e sabor (Ex.: tijolos, rochas, vidros e certos plásticos e borrachas que não são decompostos prontamente).

Segundo IPT/CEMPRE (2000, p. 29), o lixo também pode ser classificado de acordo com:

- sua natureza física: como seco e molhado;

- sua composição química: matéria orgânica e matéria inorgânica.

Também é comum classificar o lixo de acordo com a origem de sua produção. $O$ lixo de origem domiciliar, origem comercial, público (resultante dos serviços de limpeza pública), dos Serviços de Saúde, Industrial, Agrícola, Construção e Demolição. Os resíduos provenientes destes locais têm composição variada e deverão ser classificados conforme a NBR-10.004 para fins de coleta, tratamento e disposição final, de modo a evitar riscos ao meio ambiente e à saúde pública.

Os resíduos sólidos urbanos englobam todos os materiais rejeitados ou descartados nas atividades domésticas, comerciais, de serviços públicos (varrição, feiras livres, poda e outros), que apresentam características diversas, desde resíduos inertes (entulhos provenientes de obras e demolições), orgânicos, provenientes da manipulação de alimentos e poda, embalagens de vidro, plástico, metal, papel/papelão, até perigosos, como embalagens de produtos destinados a eliminação de vetores domésticos, tintas e óleos, pilhas, bem como aqueles com características de resíduos de serviços de saúde contendo fraldas, agulhas e seringas, etc. Também de encontram presentes no lixo os chamados "resíduos da modernidade tecnológica", 
tais como carcaças de microcomputadores, aparelhos eletro-domésticos de vida útil reduzida, baterias de telefone celular, resultantes dos novos hábitos vigentes nas chamadas sociedades modernas (GÜNTHER, 1999).

Considera-se lixo reciclável todo material com demanda de mercado e que pode ser utilizado como matéria prima na fabricação de novos produtos. Neste sentido, de acordo IPT/CEMPRE, (2000) reciclagem é o resultado de uma série de atividades, mediante as quais os materiais que se tornariam lixo, ou estão no lixo, são desviados, coletados, separados e processados para serem usados como matériaprima na manufatura de novo produtos.

Entende-se por minimização de resíduos, a redução de sua quantidade e, também, a diminuição de sua toxicidade, visando dispor, no ambiente, somente aquela parcela inevitável e com sua carga poluente reduzida (GÜNTHER, 1999)

\subsubsection{Os resíduos sólidos no Brasil}

Conforme Pesquisa Nacional de Saneamento Básico (PNSB), realizado pelo Instituto Brasileiro de Geografia e Estatística, IBGE (2000), são coletados no Brasil 228.413 toneladas de lixo urbano por dia e, desse lixo, 22,49\% têm destinação sanitariamente incorreta em lixões, áreas alagadas, locais não fixos e outro local e $37,03 \%$ são destinados a aterro controlado. Nas regiões Norte e Nordeste, que concentram aproximadamente $37 \%$ da população brasileira, cerca de $50 \%$ dos resíduos coletados são depositados em lixões. A Tabela 1 relaciona os dados da destinação do lixo no Brasil e por regiões, e, na Tabela 2 estão os dados da produção per capita do lixo do Brasil e de suas respectivas regiões, valores obtidos pelo quociente entre a quantidade de lixo coletado diariamente e o total da população que o produziu.

Comparando os dados divulgados nos anos de 1992 e 2000 observa-se uma melhoria em termos ambientais e sanitários na disposição do lixo, sendo, a maior parte do lixo coletado, direcionado a aterros sanitários e controlados. O lixo coletado que sofre um processamento (segregação, compostagem), antes da disposição, ainda é insignificante, inclusive com um decréscimo de 1992 para 2000. Os dados divulgados pela PNSB 2000 estão sendo alvo de críticas pelos técnicos da área. O 
Comitê de Resíduos Sólidos da Associação Brasileira de Engenharia Sanitária e Ambiental (ABES) propôs "uma articulação nacional para alteração/correção dos dados divulgados devido às distorções ocorrida na tabulação desses dados" (Anonymus 2002, p.4). As fontes de informações coletadas para compor os dados do PNSB, são os órgãos responsáveis pela execução dos serviços de limpeza urbana dos municípios e as próprias prefeituras. "Nem sempre as informações fornecidas são exatas, pois, muitas vezes não é apenas o órgão responsável pelos serviços que possui todos os meios para a operação do sistema; pode ocorrer que os veículos da limpeza urbana pertençam a uma secretaria da administração municipal, o pessoal, a outra, o combustível a uma terceira, e assim por diante, tornando-se difícil concentrar os dados num só local e conhecer todas as informações sobre a operação do sistema de forma confiável" (MONTEIRO 2002, p.12).

Um exemplo de distorção nas informações é o que ocorre no município de Feira de Santana, que embora os serviços de limpeza urbana se encontrem concentrados em uma Secretaria, a administração municipal informa, pela mídia, que a destinação dos resíduos sólidos urbanos é em aterro sanitário, quando, na verdade, o destino do lixo é em aterro controlado. 
Tabela 1 - Destino do lixo coletado no Brasil e Regiões durante os anos de 1992 e 2000.

\begin{tabular}{|c|c|c|c|c|c|c|c|c|c|c|c|c|}
\hline \multirow{4}{*}{$\begin{array}{c}\text { DESTINO DO } \\
\text { LIXO }\end{array}$} & \multirow{2}{*}{\multicolumn{2}{|c|}{$\begin{array}{c}\text { BRASIL } \\
(\%)\end{array}$}} & \multicolumn{10}{|c|}{ REGIÃO (\%) } \\
\hline & & & \multicolumn{2}{|c|}{ Norte } & \multicolumn{2}{|c|}{ Nordeste } & \multicolumn{2}{|c|}{ Sudeste } & \multicolumn{2}{|c|}{ Sul } & \multicolumn{2}{|c|}{ Centro-oeste } \\
\hline & \multicolumn{2}{|c|}{ ANO } & \multicolumn{2}{|c|}{ ANO } & \multicolumn{2}{|c|}{ ANO } & \multicolumn{2}{|c|}{ ANO } & \multicolumn{2}{|c|}{ ANO } & \multicolumn{2}{|c|}{ ANO } \\
\hline & 1992 & 2000 & 1992 & 2000 & 1992 & 2000 & 1992 & 2000 & 1992 & 2000 & 1992 & 2000 \\
\hline Lixão & 47,60 & 21,15 & 66,92 & 56,74 & 89,93 & 48,23 & 26,21 & 9,71 & 40,69 & 25,72 & 54,03 & 21,90 \\
\hline Áreas Alagadas & 1,65 & 0,11 & 22,79 & 0,51 & 0,74 & 0,11 & 0,36 & 0,06 & 0,03 & 0,18 & 0,02 & 0,06 \\
\hline Aterro Controlado & 21,90 & 37,03 & 3,99 & 28,32 & 5,45 & 14,61 & 24,62 & 46,50 & 51,97 & 24,32 & 27,00 & 32,77 \\
\hline Aterro Sanitário & 23,30 & 36,18 & 3,67 & 13,27 & 2,26 & 36,17 & 40,48 & 37,11 & 4,91 & 40,48 & 13,10 & 38,84 \\
\hline Compostagem & 3,00 & 2,87 & 2,58 & 0,04 & 0,74 & 0,19 & $\overline{4,41}$ & 3,84 & $0, \overline{98}$ & 1,75 & 5,02 & 4,80 \\
\hline Triagem & 2,20 & 0,99 & 0,00 & 0,00 & 0,72 & 0,21 & 3,50 & 0,89 & 1,21 & 4,19 & 0,33 & 0,54 \\
\hline Incineração & 0,34 & 0,44 & 0,06 & 0,08 & 0,00 & 0,05 & 0,32 & 0,67 & 0,04 & 0,15 & 0,50 & 0,18 \\
\hline Locais não fixos & - & 0,54 & - & 0,86 & - & 0,31 & - & 0,55 & - & 0,61 & - & 0,73 \\
\hline Outro local & - & 0,69 & - & 0,18 & - & 0,12 & - & 0,67 & - & 2,60 & - & 0,18 \\
\hline Resíduo especial & 0,11 & - & 0.00 & - & 0,17 & - & 0,09 & - & 0,17 & - & 0,00 & - \\
\hline TOTAL & 100,0 & 100,0 & 100,0 & 100,0 & 100,0 & 100,0 & 100,0 & 100,0 & 100,0 & 100,0 & 100,0 & 100,0 \\
\hline
\end{tabular}

Fonte: Ano 1992: Nunesmaia (1997) - Ano 2000: Adaptado da Pesquisa Nacional de Saneamento Básico, IBGE, 2000

Tabela 2 - Quantidade de lixo coletado e geração per capita no Brasil e regiões.

\begin{tabular}{c|c|c|c|c|c|c}
\hline DADO & Brasil & Norte & Nordeste & Sudeste & Sul & $\begin{array}{c}\text { Centro- } \\
\text { oeste }\end{array}$ \\
\hline $\begin{array}{c}\text { População } \\
\left(\mathrm{n}^{\mathrm{o}} \text { pessoas }\right)\end{array}$ & 169.799 .170 & 12.900 .704 & 47.741 .711 & 72.412 .411 & 25.107 .616 & 11.636 .728 \\
\hline $\begin{array}{c}\text { Lixo coletado } \\
(\mathrm{t} / \text { dia })\end{array}$ & 228.413 & $11.067,1$ & $41.557,8$ & $141.616,8$ & $19.874,8$ & $14.296,5$ \\
\hline $\begin{array}{c}\text { Per capita } \\
(\mathrm{kg} / \text { pes.dia })\end{array}$ & 1,345 & 0,859 & 0,870 & 1,956 & 0,792 & 1,229 \\
\hline
\end{tabular}

Fonte: Adaptado da Pesquisa Nacional de Saneamento Básico, IBGE 2000

População conforme censo demográfico, IBGE 2000

A geração per capita de lixo é influenciado pelo nível de renda da população, hábitos de consumo, clima etc. Segundo IBGE (2000), o rendimento médio mensal 
da população ocupada, segundo regiões do Brasil é de: $R \$ 718,50$ para a região Sudeste; $\mathrm{R} \$ 642,40$ na região Centro-Oeste; $\mathrm{R} \$ 626,70$ na região Sul; $\mathrm{R} \$ 512,00$ na região Norte; e de R\$ 354,40 na região Nordeste. Comparando os dados da geração per capita obtidos nas regiões Sudeste e Centro-Oeste com os valores do rendimento médio, observa-se uma relação direta entre esses indicadores (maior renda implica maior geração de lixo per capita). Essa relação não se verifica na região Sul, que embora apresente o terceiro maior rendimento é a menor geradora de resíduos per capita. Infere-se que pode estar havendo influência de outras variáveis, tais como: hábitos de consumo, clima, valores superestimados do lixo coletado na região Norte e Nordeste ou subestimados na região Sul.

No estado da Bahia, conforme SEI (2002), 69,6\% dos domicílios são atendidos pela coleta pública. O lixo não coletado é descartado em caçambas para posterior coleta pública $(16,0 \%)$, queimado $(4,1 \%)$, enterrado $(0,4 \%)$, jogado em terreno baldio $(8,9 \%)$, jogado em rio, lago e mar $0,6 \%$ e outro destino $(0,4 \%)$.

\subsubsection{Legislação Federal sobre resíduos}

No Brasil, a gestão dos resíduos sólidos urbanos é de responsabilidade das Prefeituras Municipais, compreendendo a coleta, o transporte, o tratamento e o destino final. Entretanto, a União tem a função de traçar normas amplas e adaptáveis à realidade nacional, pois, segundo MACHADO (1995), sente-se, no Brasil, a ausência de políticas de co-responsabilização da União nas tarefas de “...limpeza pública e coleta, transporte e disposição dos resíduos sólidos, .... dada a importância ambiental da matéria com reflexos diretos na saúde da população".

A Portaria MINTER nº53, de 01 de março de 1979 (BRASIL 1979), foi a primeira legislação federal específica sobre resíduos. Foi essa portaria que proibiu a incineração de resíduos em domicílios e a céu aberto, o lançamento de lixo em corpos d’água e sua utilização "in natura" na alimentação de animais e na agricultura.

Conforme MORAES e MENEZES (2002), “a área do saneamento, à qual o componente resíduos sólidos está ligado, ressente-se, até o momento, de uma política nacional formulada de forma participativa e instituída por lei, tornando-se alvo fácil 
da ganância pública e privada, face à fragilidade que se estabelece por falta de instrumentos normativos". Várias tentativas de formulação de uma política de resíduos sólidos para o Brasil têm sido feitas, contudo sua aprovação na Câmara Federal não foi efetivada.

A seguir, são listadas as principais leis e resoluções vigentes que direcionam o planejamento e o projeto do manejo, ambientalmente correto, dos resíduos sólidos em âmbito nacional:

- Constituição Federal, 1988, responsabiliza o município pelo serviço de coleta e destino final dos resíduos domésticos;

- Lei Federal nº 6.938 de 31 de agosto de 1981 - Dispõe sobre a Política Nacional de Meio Ambiente, seus fins e mecanismos de formulação e aplicação, e dá outras providências;

- Lei Federal no 9.795 de 27 de abril de 1999 - Dispõe sobre a Educação Ambiental e institui a Política Nacional de Educação Ambiental e dá outras providências;

- Lei Federal nº 9.605 de 1998 - Crimes ambientais;

- Resolução CONAMA 001/86 - Dispõe sobre definições, responsabilidades, critérios básicos e diretrizes gerais para uso e implementação da Avaliação de Impacto Ambiental;

- Resolução CONAMA 006/1988 - Dispõe sobre licenciamento de atividades industriais e geração de resíduos;

- Resolução CONAMA 005/1993 - Resíduo de Serviço de Saúde, Portos e Aeroportos;

- Resolução CONAMA 009/1993 - Rerrefino de óleos lubrificantes;

- Resolução CONAMA 007/1994 - Importação e Exportação de Resíduos Perigosos;

- Resolução CONAMA 257/1999 - Disciplina o descarte e o gerenciamento ambientalmente adequado de pilhas e baterias usadas;

- Resolução CONAMA 258/1999 - Destinação de pneumáticos - Determina que os fabricantes e os importadores de pneumáticos sejam obrigadas a 
coletar e dar uma destinação final, ambientalmente adequada, a todos os pneus inservíveis existentes no território nacional.

Essas duas últimas resoluções foram as primeiras a responsabilizar os fabricantes pelo destino final de seus produtos pós-consumo.

- Resolução CONAMA 27/2001 - Estabelece o novo código de cores para os diferentes tipos de resíduos;

- Resolução CONAMA 283/2001 - Dispõe sobre o tratamento e destinação final dos resíduos de serviços de saúde;

- Resolução CONAMA 307/2002 - Estabelece diretrizes, critérios e procedimentos para a gestão dos resíduos da construção civil;

- Resolução CONAMA 308/2002 - Licenciamento Ambiental de sistemas de disposição final dos resíduos sólidos urbanos em municípios de pequeno porte;

- Resolução CONAMA 316/2002 - Dispõe sobre procedimentos e critérios para o funcionamento de sistemas de tratamento térmico de resíduos;

A responsabilidade pelo manejo adequado dos resíduos sólidos varia de acordo com a sua origem. O quadro 1 relaciona essas responsabilidades.

Quadro 1 - Responsabilidade pela coleta e destino final do lixo em função da fonte geradora.

\begin{tabular}{|l|c|}
\hline \multicolumn{1}{|c|}{ TIPO DE RESÍDUO } & RESPONSÁVEL \\
\hline Domiciliar & Município \\
\hline Comercial & Município \\
\hline Construção e demolição & Gerador \\
\hline Público & Município \\
\hline Serviços de saúde & Gerador \\
\hline Industrial & Gerador \\
\hline
\end{tabular}




\subsubsection{Características dos resíduos sólidos gerados em ambientes universitários}

Os resíduos sólidos gerados em ambientes universitários englobam, além daqueles classificados com resíduos sólidos urbanos, alguns resíduos classificados como industriais e como resíduos de serviços de saúde. Dentre os resíduos sólidos urbanos encontram-se os resíduos orgânicos provenientes da manipulação de alimentos, da manutenção e limpeza de áreas verdes (poda), embalagens de vidro, plástico, metal, papel/papelão, resíduos de varrição, entulhos provenientes de obras e demolições. Também são descartados, juntamente com esses resíduos sólidos classificados como resíduos comuns, carcaças de microcomputadores, aparelhoseletrodomésticos e laboratoriais, como também pilhas e baterias, lâmpadas fluorescentes e embalagens de resíduos perigosos como de pesticidas, herbicidas e tintas e óleos. Esses resíduos são gerados nos setores administrativo, de ensino, como salas de aula e laboratórios, e de apoio às atividades acadêmicas, tais como restaurantes e cantinas, creches e no setor de limpeza e manutenção.

Além desses setores, as universidades têm, em sua estrutura, laboratórios de ensino e pesquisa na área de química, de biologia, de física, das engenharias e da saúde, onde são gerados diversos resíduos classificados como classe I (perigosos) (ABNT 1987), incluídos nesses, os resíduos de serviços de saúde classificados, conforme Resolução CONAMA 307/2002, como biológicos, químicos e rejeitos radioativos. Esses resíduos são gerados continuamente nas atividades de ensino, e de forma esporádica nas atividades de pesquisa, dependendo, portanto, dos cursos oferecidos em cada universidade e das pesquisas realizadas. Nesse cenário, o diagnóstico da geração e da classificação dos resíduos e o acompanhamento ao longo do tempo das atividades realizadas em cada universidade são importantes para orientar a segregação, a coleta, o tratamento e a destinação final desses resíduos sólidos gerados nesse ambiente, uma vez que requerem um tratamento especial.

Em relatório sobre esse tipo de resíduo gerado na Universidade de Campinas, produzido pela Coordenadoria Geral da Universidade (CGU, 2002), foi observado que a Universidade possui duas características distintas: "devido ao volume e a razoável regularidade de composição dos resíduos, a Universidade pode ser 
comparada a uma indústria, já que a composição dos resíduos não varia. Isso pode ser exemplificado nos resíduos biológicos da área médica: eles são volumosos e de composição pouco variada (materiais contaminados, gazes, carcaças de animais, bolsas de sangue, seringas etc.). Por outro lado, quanto às unidades de pesquisa (área biológica, química ou radioativa), a composição dos resíduos se altera drasticamente: de maneira geral, a escala diminui, entretanto a variedade dos resíduos aumenta consideravelmente".

Pelo exposto, observa-se que a responsabilidade das universidades no adequado gerenciamento de seus resíduos, tendo em vista a minimização dos impactos no meio ambiente e na saúde pública, passa pela sensibilização dos professores, alunos e funcionários envolvidos diretamente na geração desses resíduos, e de seus diversos setores administrativos que podem ter relação com a questão (prefeitura, compras, almoxarifado etc).

\subsubsection{Resíduos sólidos, saúde pública e meio ambiente}

A doença, ao longo da história da humanidade, já foi considerada como um fato natural, no sentido de fazer parte do ciclo da vida dos seres vivos; foi, também, considerada como castigo dos deuses, enquanto que a saúde, como benção divina. As cosmologias religiosas eram utilizadas para explicar a doença, a exemplo da lepra, que atacava os "impuros", ou seja, aqueles que adoravam os ídolos, profanavam ou roubavam bens públicos, faltas que contrariavam os padrões religiosos da época. Uma das teorias que tentaram explicar a doença ficou conhecida como teoria dos Miasmas, pela qual se acreditava que o ar contaminado por gases provenientes da decomposição de matéria orgânica animal ou vegetal espalhava a doença pela população. Até os terremotos e vulcões, que poluíam o ar, foram responsabilizados pelas pestes que assolaram os moradores de cidades durante o período medieval.

No período industrial, foi intensificada a urbanização e, com o crescimento das cidades, surgiram várias doenças epidêmicas, despertando, na comunidade, a consciência de que o acúmulo de fábricas e de moradores condicionava o aparecimento e a difusão dessas doenças. Por meio de observações, ficou claro que a 
doença estava relacionada com a imundície do ambiente, com a falta de escoamento da água de chuva e com o deficiente abastecimento de água e de meios para remover rejeitos das casas e das ruas. Assim, os problemas de "saúde pública passaram a ser considerados mais de Engenharia do que de Medicina" (ROSEN 1994).

A teoria da unicausalidade surgiu com a descoberta dos micróbios (vírus e bactérias), por Louis Pasteur e, portanto, do agente etiológico causador de doença. O fato de algumas pessoas não serem suscetíveis às doenças microbianas, suscitou dúvidas quanto a essa teoria. Através de estudos epidemiológicos, surgiu a teoria da multicausalidade, na qual fatores sociais e ambientais, e o estilo de vida das pessoas interferem na saúde das comunidades. Assim, a saúde passa a ser entendida em sentido amplo, como um dos fatores que interferem na qualidade de vida, sendo pois, em seu sentido mais abrangente, "resultante das condições de alimentação, habitação, educação, renda, meio ambiente, trabalho, transporte, emprego, lazer, liberdade, acesso e posse da terra e acesso a serviços de saúde. A saúde, antes de tudo, é o resultado das formas de organização social da produção, as quais podem gerar grandes desigualdades nos níveis de vida" (Relatório Final da VIII Conferência Nacional de Saúde, 1986). Portanto, nos dias atuais a referência deve ser ao processo de saúde e doença, isto é, aos dois estados de um só fenômeno. Na prática é chamado de gradiente de saúde, tanto individual como coletivo. "O importante é reconhecer essa abrangência e complexidade causal: saúde e doença não são estanques, isoladas, de causação aleatória - não se está com saúde ou doença por acaso. Há uma determinação permanente, um processo causal, que se identifica com o modo de organização da sociedade. Daí se dizer que há uma "produção social da saúde e/ou da doença" (ALMEIDA et al. 1998).

Levando-se em conta estas considerações, pode-se definir Saúde Pública como intervenções multidisciplinares e intersetoriais, resultantes do conhecimento e da análise do processo saúde/doença de uma determinada comunidade. Sua atuação visa fundamentalmente ao coletivo e à prevenção, não anulando contudo o individual e a cura. Essas ações fazem um ajuste satisfatório nas forças que tendem a perturbar o equilíbrio do processo saúde/doença. As perturbações dar-se-ão no chamado campo da saúde, representadas pelos fatores biológicos, fatores ambientais, estilo de vida e acesso aos serviços de saúde. 
No Brasil, esta visão de saúde pública surgiu através do movimento da Reforma Sanitária, iniciado na década de 70 e consolidado em 1986, na VIII Conferência Nacional de Saúde e pela Constituição de 1988, na qual a saúde se configura como direito de cidadania e dever do Estado, numa perspectiva de articulação de políticas econômicas e sociais e a criação de um Sistema Único de Saúde (SUS) (CHIORO et al. 1997).

O SUS, como política de saúde, tem como doutrina a Universalidade (todas as pessoas têm direito à saúde), Eqüidade (todo cidadão será atendido e acolhido conforme as suas necessidades) e Integralidade (as ações de saúde devem ser combinadas e voltadas ao mesmo tempo para a prevenção, a promoção, a cura e a reabilitação), ou seja, o atendimento deve ser feito também para erradicar e diminuir os riscos, além de tratar os danos.

Para atingir o objetivo doutrinário de integralidade, os instrumentos utilizados são:

Promoção: ações que buscam eliminar ou controlar as causas das doenças e agravos, tais como saneamento ambiental, imunizações, vigilância à saúde e sanitária, habitação, educação, entre outras.

Proteção: são ações específicas para prevenir riscos e exposições às doenças, ou seja, para manter o estado de saúde. São exemplos dessas ações, o tratamento da água para evitar a cólera, o manejo adequado do lixo para evitar a dengue e a leptospirose, a prevenção de doenças sexualmente transmissíveis, prevenção do câncer de mama e próstata, entre outras.

Recuperação: Ações que atuam sobre os danos e que evitam a morte das pessoas e as sequielas. É o atendimento médico ambulatorial e especializado, o atendimento odontológico, as internações hospitalares e a reabilitação física.

Pelo exposto, resulta que "os problemas de saúde dificilmente podem ser resolvidos por ações exclusivas do setor saúde. Freqüentemente um problema de saúde vai exigir atividades que se situam em outros setores" (MIR 1990). Nesse contexto, questões como o manuseio indevido e a má disposição dos resíduos sólidos no meio ambiente, e a Educação Ambiental estão diretamente relacionadas com a promoção e a proteção da saúde, podendo ser considerada como indutora da participação comunitária nas ações de saneamento. Tem-se, como exemplo, a atual 
epidemia nacional de dengue, transmitida pelo mosquito Aedes aegypti que, para ser erradicado, faz-se necessária a ação da comunidade, destruindo os lugares de sua reprodução. Da mesma forma, não faz sentido uma drenagem urbana adequada, se as canalizações construídas para esse fim estiverem obstruídas pelo lixo. Nos dias de chuva, teremos enchentes, causando danos à saúde dos moradores. Portanto, o gerenciamento adequado dos resíduos sólidos urbanos, levando-se em conta a participação da comunidade, é importante, pois possibilitará que os indivíduos atuem também no processo saúde/doença.

A $25^{a}$ Conferência Sanitária Pan-Americana, realizada em 1998, em Washington (OPAS 1999) aprovou as orientações estratégicas e programáticas para 1999-2002 direcionadas para o alcance da meta mundial de saúde para todos no século XXI. Uma delas é apoiar a promoção e a implementação de ações de atenção primária ambiental (APA) que proporcionem às comunidades ambientes que promovam o desenvolvimento, com sua participação ativa na identificação de suas necessidades e na definição das correspondentes soluções. "A APA é uma ação ambiental, basicamente preventiva e participativa em nível local, que reconhece o direito do ser humano de viver em um ambiente saudável e adequado, e a ser informado sobre os riscos do ambiente em relação à saúde, bem-estar e sobrevivência, ao mesmo tempo que define suas responsabilidades e deveres em relação à proteção, conservação e recuperação do ambiente e da saúde" (OPAS 1999).

Como já exposto, a composição dos resíduos sólidos gerados nas residências e resultantes das atividades humanas é variada. Contém, não só elementos como diversas embalagens de vidro, metal, plástico e papel, como, também, elementos considerados perigosos. Conforme FERREIRA (1997) "até há poucos anos, os resíduos domiciliares eram considerados como de pequeno risco para o meio ambiente. Hoje em dia, seja pela introdução de novos produtos na vida moderna, seja pelo maior conhecimento dos impactos de determinados materiais no ambiente ou pela quantidade crescente dos mesmos, considera-se que os resíduos domiciliares são uma ameaça à integridade do meio ambiente, contendo itens que podem ser classificados como perigosos". 
Os impactos desses resíduos no ambiente e, conseqüentemente, na saúde pública, condicionados às formas de tratamento e de disposição final empregados, são inúmeros. O chorume, decorrente da degradação da matéria orgânica presente no lixo, e intensificado pelas águas de chuva que percolam através do lixo disposto de forma inadequada, pode causar alterações na qualidade das águas superficiais e subterrâneas impactando a flora e a fauna aquática. Por outro lado, o lançamento do lixo nos corpos d'água provoca o assoreamento de rios e lagos, prejudicando e comprometendo seus diversos usos. Nos centros urbanos, pelo hábito de jogar lixo nos passeios públicos, observa-se, em períodos de chuva, grande quantidade de lixo sendo carreado para o interior dos sistemas de drenagem urbana, contribuindo para os episódios de enchentes e causando danos à saúde da população e prejuízos econômicos. A queima dos resíduos, além de provocar odores indesejados, pode gerar compostos diferentes daqueles neles presentes, tais como óxidos de enxofre, dioxinas e furanos (AGUIAR, 1999). Também podem ser citados como impacto desses resíduos no ambiente e na saúde pública, a contaminação do solo com conseqüente redução da biodiversidade, e a proliferação de vetores responsáveis pela transmissão de inúmeras doenças, devido ao incremento de criadouros que a disposição inadequada do lixo propicia, além de prejuízos econômicos. Os agravos/efeitos do manejo inadequado dos resíduos sólidos no meio ambiente e na saúde pública, como econômicos estão resumidos no quadro 2 .

Nos países sub-desenvolvidos, é comum a presença de populações envolvidas na operação de catação de materiais presentes no lixo, estando sujeitas a uma gama de agravos, em decorrência da exposição aos agentes físicos, químicos e biológicos que essa atividade implica. Esses agravos vão, desde ferimentos em geral, pela manipulação de objetos cortantes e perfurantes sem equipamento de proteção, a doenças do trato gastrointestinal, doenças de pele e posturais (NASCIMENTO JÚNIOR, 1999). Também pode existir a possibilidade de intoxicações por produtos químicos voláteis ou por gases resultantes da queima do lixo. 
Quadro 2 - Impactos ambientais, sanitários e efeitos econômicos causados pelo manejo inadequado do lixo urbano

\begin{tabular}{|c|l|}
\hline \multicolumn{1}{|c|}{ IMPACTOS } & \multicolumn{1}{|c|}{ AGRAVOS/EFEITOS } \\
\hline \multirow{2}{*}{ Meio ambiente } & $\begin{array}{l}\text { Degradação dos recursos hídricos } \\
\text { Desmoronamento de encostas } \\
\text { Entupimento de bueiros (inundações) } \\
\text { Poluição do ar } \\
\text { Poluição visual (estética) } \\
\text { Redução da Biodiversidade } \\
\text { Esgotamento dos recursos naturais }\end{array}$ \\
\hline Sanitários & $\begin{array}{l}\text { Favorece a proliferação de agentes patogênicos e de } \\
\text { vetores de transmissão de enfermidades } \\
\text { Presença de urubus (acidentes aéreos) } \\
\text { Acidentes de trânsito (lixo disposto em passeios públicos) }\end{array}$ \\
\hline Econômico & $\begin{array}{l}\text { Ocupação de áreas pelo lixo } \\
\text { Desvalorização de terrenos } \\
\text { Custo da recuperação de áreas degradadas } \\
\text { Entupimento do sistema de drenagem urbana } \\
\text { Turismo }\end{array}$ \\
\hline
\end{tabular}

O lixo depositado a céu aberto funciona como fator de atração a macro vetores como baratas, moscas, mosquitos, ratos e outros animais silvestres, ou domésticos, transmissores de inúmeras doenças.

No caso de alguns mosquitos, o lixo pode servir de criadouro devido à água que se acumula em alguns objetos, tais como: embalagens de plásticos, latas, pneus, cacos de vidro ou pedaços de telha. Esses reservatórios com água são bons criadouros para a proliferação do Culex e para o Aedes aegypty, causando grande desconforto e riscos à saúde dos moradores (NASCIMENTO JUNIOR, 1999). O quadro 3 relaciona as enfermidades causadas pelos vetores. 
Quadro 3 - Enfermidades causada por vetores relacionados ao lixo

\begin{tabular}{|c|c|c|}
\hline VETORES & FORMA DE TRANSMISSÃO & $\begin{array}{c}\text { PRINCIPAIS } \\
\text { ENFERMIDADES }\end{array}$ \\
\hline Ratos & $\begin{array}{l}\text { Através de mordidas, urina e fezes } \\
\text { Por meio de pulgas que vivem no corpo do rato }\end{array}$ & $\begin{array}{l}\text { Peste Bubônica } \\
\text { Tifo murino } \\
\text { Leptospirose }\end{array}$ \\
\hline Moscas & $\begin{array}{l}\text { Por via mecânica (por meio das asas, patas e } \\
\text { corpo) } \\
\text { Por meio das fezes e saliva }\end{array}$ & $\begin{array}{l}\text { Febre tifóide } \\
\text { Salmonelose } \\
\text { Cólera } \\
\text { Amebíase } \\
\text { Desinteria } \\
\text { Giardíase }\end{array}$ \\
\hline Mosquitos & Através de picadas do mosquito no homem & $\begin{array}{l}\text { Malária } \\
\text { Leischmaniose } \\
\text { Febre amarela } \\
\text { Dengue } \\
\text { Filariose }\end{array}$ \\
\hline Baratas & $\begin{array}{l}\text { Por via mecânica (por meio das asas, patas e } \\
\text { corpo) e por fezes }\end{array}$ & $\begin{array}{l}\text { Febre tifóide } \\
\text { Cólera } \\
\text { Giardíase }\end{array}$ \\
\hline Suínos & Por ingestão de carnes contaminadas & $\begin{array}{l}\text { Cisticercose } \\
\text { Toxoplasmose } \\
\text { Triquinose } \\
\text { Teníase }\end{array}$ \\
\hline Aves & Por meio das fezes & Toxosplamoses \\
\hline
\end{tabular}

Fonte: Barros et al. (1995).

Pelas implicações ambientais e de saúde que o manejo inadequado dos resíduos sólidos promove, a resolução desse problema deve ser uma preocupação de toda a sociedade e do governo. Percebe-se que houve, nos últimos anos, uma melhora, inclusive no Brasil, em relação ao destino final do lixo, contudo o reaproveitamento dos resíduos ainda é insignificante (ver tabela 1). 
Passados dez anos da Rio 92, o Brasil tem muito que avançar em termos de destinação final e de aproveitamento, por métodos seguros dos resíduos gerados. Segundo WWI (2000), as medidas adotadas nos anos 90 em relação à essa questão foram muito poucas. Embora houve avanços quanto à forma dos bens e serviços a serem produzidos e consumidos, na redução no uso de materiais e na geração de lixo, a maioria continua ainda na fase de projeto ou em estágio piloto.

Comentando sobre as disparidades globais de riqueza, alerta que um quinto da população mundial vive com um dólar ou menos por dia, enquanto os ricos do mundo padecem 'dos sintomas de excesso, como a obesidade e que, atualmente, na maioria dos países das nações industrializadas, grande parte dos materiais é usado apenas uma vez e descartado. "Os dados do desmatamento nos países em desenvolvimento são perturbadores quando ligados a hábitos perdulários de consumo. Enquanto $80 \%$ da população mundial não tem acesso a papel suficiente para atender às mínimas necessidades de alfabetização e comunicação básicas, países ricos consomem papel a um ritmo assustador. O Americano médio gasta 19 vezes mais papel do que uma pessoa média num país em desenvolvimento e a maioria vira lixo: menos da metade do papel consumido nos Estados Unidos é reciclado" (WWI 2000).

Atacar a causa fundamental da crescente geração de lixo e de sua presença no ambiente é o grande desafio atual. Isso passa pela mudança dos padrões não sustentáveis de produção e consumo, e pela transformação da sociedade: de sociedade de consumo para uma sociedade sustentável, pois sobre a questão do lixo, conforme GONÇALVES (2001) "ainda é possível agir”:

"Sobre o lixo ainda temos o poder de agir, sem que nos questionemos que, o que mais tem no lixo é embalagem, seja de vidro ou de plástico, de isopor ou madeira, papel ou papelão. E que "embalagem" deriva do verbo embala, que, entre outros sentidos, significa fazer dormir: assim, embalados pela embalagem (e elas hoje são cientificamente planejadas para induzir-nos ao sonho), sonhando acordados, realizamos nosso sonho comprando. Templos modernos, shoppings. Nós, que tanto criticamos o Lixo Ocidental, nos transformamos hoje em coletores do lixo Ocidental" (GONÇALVES 2001, p. 146). 


\subsubsection{O lixo: da geração à disposição final e possibilidades de seu gerenciamento}

O gerenciamento dos resíduos sólidos urbanos, na maioria dos municípios brasileiros, resume-se a coletá-los e dispô-los no solo, muitas vezes, em áreas próximas a corpos d'água ou fundos de vale. Muitos municípios despejam o lixo coletado em propriedades rurais a fim de servir como "alimento para o gado e para adubar a terra", procedimento este realizado, a pedido do proprietário que é, inclusive, muitas vezes, remunerado pela municipalidade. Esse fato demonstra o desconhecimento dos riscos ambientais e sanitários provocados pelos responsáveis por tais serviços de limpeza, que criam uma forma fácil da prefeitura livrar-se do lixo produzido na área urbana.

O gerenciamento simplista de coletar e depositar no solo deve evoluir para um gerenciamento em que o lixo gerado seja tratado de forma integrada. Conforme (IPT/CEMPRE, 2000), "o gerenciamento integrado do lixo municipal é um conjunto articulado de ações normativas, operacionais, financeiras e de planejamento que uma administração municipal desenvolve (com base em critérios sanitários, ambientais e econômicos) para coletar, segregar, tratar e dispor o lixo de sua cidade". Acredita-se que a gestão integrada de resíduos deve ir além disto, e estar baseada, também, em critérios sociais, ou seja na participação popular, para que a sociedade possa definir, localmente, novas regras de convivência, novas normas e novos valores para a definição de seus padrões de produção e consumo, bem como a utilização de tecnologias mais apropriadas ao seu contexto. Segundo MORAES (2002), "a busca de um novo paradigma para o adequado manejo dos resíduos sólidos é certamente um dos principais desafios deste novo milênio. As soluções geralmente isoladas e estanques, até aqui praticadas, cometem o equívoco de tratar de forma parcial a problemática de resíduos sólidos urbanos. A solução pode estar no desenvolvimento de modelos integrados e sustentáveis, que considerem desde o momento da geração dos resíduos, a maximização de seu reaproveitamento e reciclagem, até o processo de tratamento e disposição final, ou seja, a Gestão Integrada e Sustentável de Resíduos Sólidos Urbanos". 
Para o gerenciamento dos resíduos sólidos urbanos, não existe nem solução mágica, nem solução pronta, por isso, qualquer proposta deve passar pelo conhecimento de cada cidade, de seu lixo, de suas características sócio-culturais e econômicas, além da capacitação de recursos humanos e do envolvimento da população através da educação ambiental (DIAS e NUNESMAIA, 1995). "Como o primeiro impacto causado pelo resíduo sólido é local, a solução desse problema deve ser iniciada com a introdução de alternativas ambientalmente seguras e a tomada de decisão deve incluir a participação popular, não devendo estar sob controle exclusivo das autoridades" (Fórum Internacional das ONG's,1992). Em termos gerais, o lixo, após ser gerado, poderá passar pelas seguintes fases, dependendo da proposta adotada para seu gerenciamento:

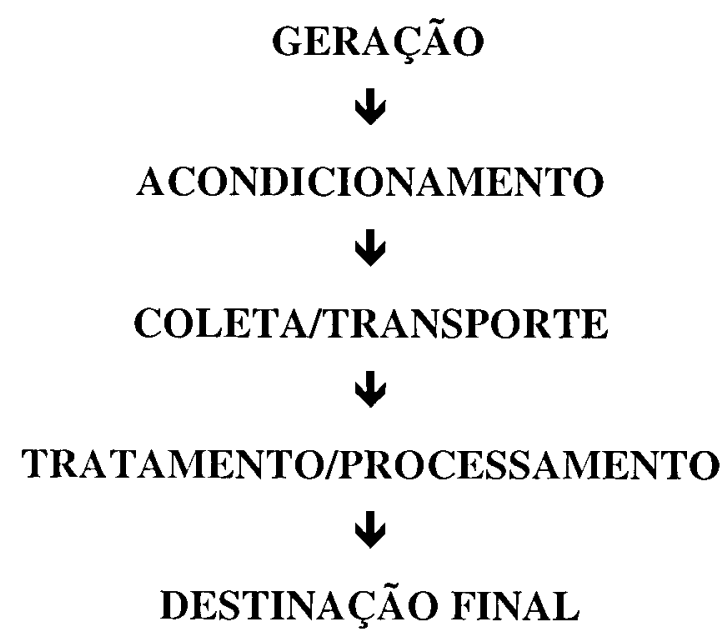

As formas de acondicionamento, da coleta, de tratamento e disposição final dependerão de estudos preliminares que deverão ser realizados em cada localidade e/ou estabelecimento gerador. Estes estudos deverão buscar informações sobre tipo de resíduos gerados, composição, quantidade, características físicas, químicas e biológicas, mercado para recicláveis, entre outros.

Segundo GÜNTHER (2000), a geração de resíduos sólidos é: inerente à atividade humana; inesgotável e democrática (independe de sexo, idade, classe social); crescente (a geração per capita tende a aumentar pela melhoria das condições de vida e mediante a incorporação das embalagens descartáveis); complexa e poluidora (diversidade de produtos não biodegradáveis e perigosos). A 
quantidade de resíduos gerados pela comunidade depende dos hábitos, da cultura, das estações do ano, do nível de renda da população e da vocação do local, o que determina as atividades desenvolvidas na área. Da mesma forma, a produção por tipo de resíduos varia de acordo de com o porte da localidade. A quantificação dos resíduos gerados é obtida por meio de um estudo técnico denominado de caracterização física ou estudo gravimétrico dos resíduos sólidos. Os valores obtidos nesse estudo retratam o modo de vida de uma comunidade. ARAGÃO e CAMPOS (2002), ao realizarem a caracterização física dos resíduos produzidos em uma escola pública, puderam observar que os hábitos alimentares dos alunos não eram saudáveis, em função do número significativo de embalagens de biscoitos encontrados na amostra de lixo, como também observaram a existência de depredação de equipamentos escolares devido aos pedaços de materiais provenientes desses equipamentos encontrados durante o processo de caracterização do lixo.

O Gráfico 1 mostra a porcentagem dos principais componentes encontrados no lixo urbano de cinco localidades do interior do Estado da Bahia: Feira de Santana com 450.000 habitantes; Lençóis, com 3.491 habitantes; Lamarão, com 1.700 e o Arraial de São Francisco da Mombaça com 700 habitantes (DIAS e VAZ, 2002). 
Gráfico 1 - Caracterização do lixo gerado em localidades do interior do Estado da Bahia.

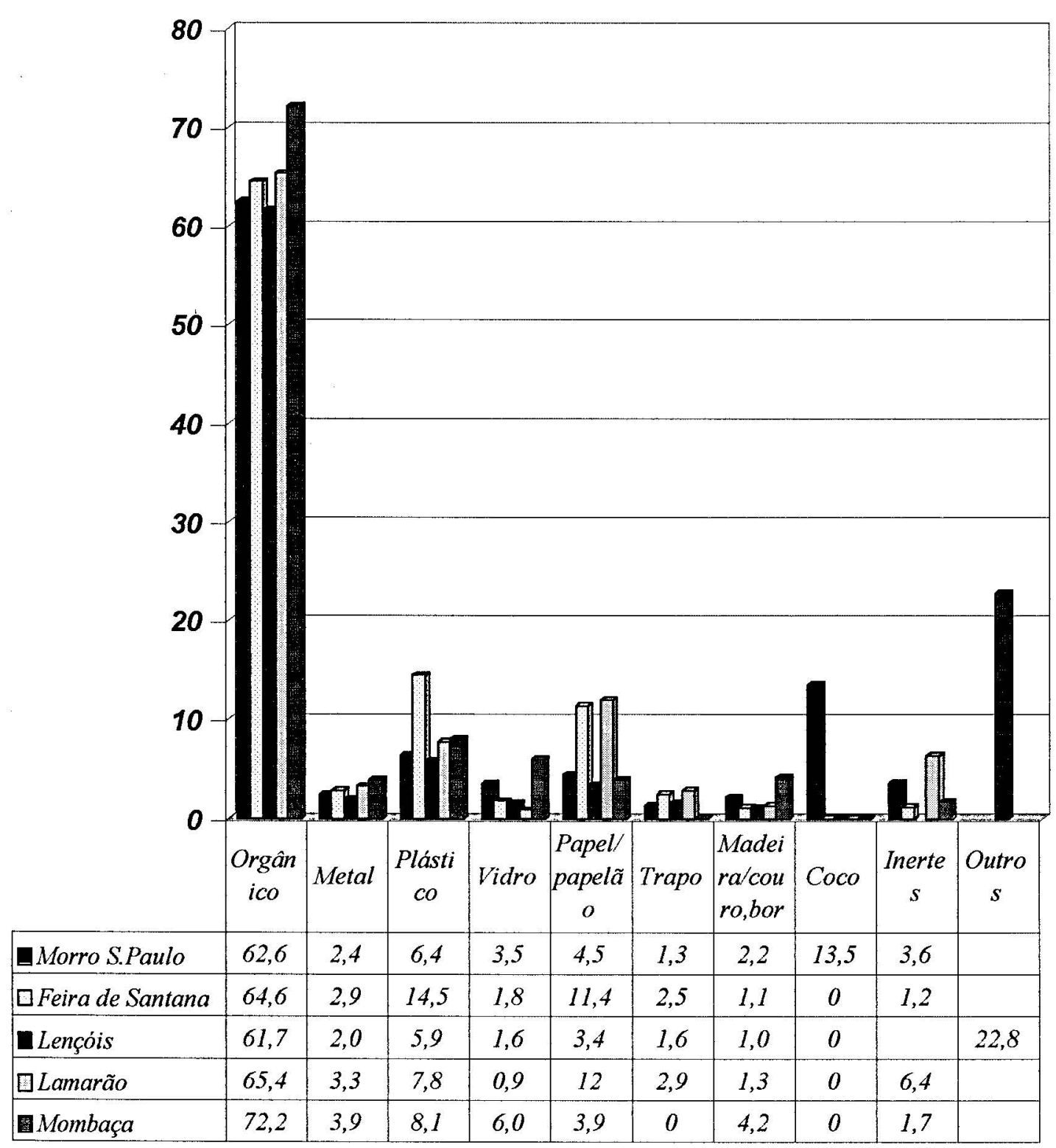

Fonte: DIAS e VAZ, (2002)

Observa-se, pelos dados obtidos, a predominância da fração orgânica nas localidades em estudo, representando cerca de $60 \%$ do total coletado, sendo maior para as localidades de pequeno porte. Devido aos hábitos e serviços encontrados nas cidades maiores, estas apresentam consideráveis quantidades de papel/papelão e plástico, depois do lixo orgânico, sugerindo uma maior utilização de embalagens. Os 
dados assim obtidos darão os subsídios básicos para o dimensionamento e a forma de processamento desses resíduos.

\subsubsection{Processamento dos resíduos}

Os resíduos, após serem coletados, poderão ser processados de acordo com suas características para atender ao planejamento proposto para o seu manejo. O processamento poderá ser: mecânico, biológico ou térmico.

O processamento mecânico tem a função de preparar os resíduos para o transporte (compactação, prensagem) ou para tratamento posterior (trituração que pode preceder a compostagem ou a incineração).

O processamento biológico acontece quando os resíduos orgânicos sofrem degradação através de microorganismos. Esse processo é chamado de compostagem que, segundo PEREIRA NETO (1989), é um processo aeróbico controlado e desenvolvido por uma população mista de microorganismos em duas fases distintas a saber: a primeira, fase ativa, efetuada quando ocorrem as reações bioquímicas de oxidação mais intensas predominantemente termofílicas, e a segunda, ou fase de maturação, quando ocorre o processo de humificação". O resultado do processo é o húmus (composto orgânico) considerado um excelente recondicionador de solos. $\mathrm{O}$ êxito do método dependerá da separação do resíduo orgânico da massa do lixo e do monitoramento da temperatura, umidade e aeração da leira ou pilha de compostagem. Esse processo é indicado para pequenas comunidades, uma vez que não exige o emprego de equipamentos especiais, podendo ser operado manualmente.

As Usinas de Triagem e Compostagem são instalações onde os materiais recicláveis dos resíduos domiciliares, ou seja os que podem retornar ao processo de produção como matéria prima, tais como: plástico, papelão, papel, vidro e metal, são separados da fração orgânica que é submetida ao processo de compostagem (FERREIRA 1997).

A compostagem doméstica é uma forma de minimização dos resíduos na fonte geradora. O processo utiliza os princípio da compostagem do resíduo orgânico no próprio local de geração (DIAS e SOUZA 1998). 
A incineração é um exemplo de processamento térmico de resíduos, que teve origem numa prática muito antiga que consistia em empilhar o lixo e atear fogo a céu aberto. Essa prática rudimentar ainda é muito utilizada em pequenas comunidades onde os serviços de coleta são ineficientes ou inexistentes.

Conforme AKUTSU (1992), a queima de resíduos realizada em incineradores "consiste na oxidação de matéria carbonácea a temperaturas elevadas através do oxigênio, liberando, como sub-produtos principais, $\mathrm{CO}_{2}$, água e energia na forma de calor, quando o material incinerado contiver como constituintes principais o carbono, hidrogênio e oxigênio".

A incineração reduz o volume dos resíduos, transformando-o em cinzas e escórias, emitindo gases durante a combustão. É realizada em fornos especiais onde é garantido ar para a combustão, turbulência, tempos de detenção e temperatura adequada.

No Brasil, são poucos os incineradores em operação, havendo uma grande discussão em relação a sua implantação devido aos custos envolvidos, exigência de mão de obra especializada para operação e necessidades de equipamentos de controle para evitar a poluição do ar.

\subsubsection{Disposição final}

Os resíduos sólidos que não puderem ser utilizados, reciclados, e os refugos resultantes dos processos biológico ou térmico, devem ter disposição final sanitária e ambientalmente adequada. $\dot{E}$ interessante refletir sobre o mito existente entre muitos administradores municipais que consideram que a adoção de coleta seletiva elimina a necessidade da construção de aterros sanitários ou controlados. Na Bahia, esse fato foi observado no município de Sapeaçu, onde foi construída uma usina de triagem e compostagem, não sendo prevista a destinação final adequada para o lixo que não foi possível ser processado. O resultado é um lixão nas imediações da usina, trazendo, como consequiência, todos os problemas ambientais citados anteriormente (Figura 1).

A técnica atual utilizada e recomendada para a disposição final dos resíduos urbanos é o aterro sanitário, embora, para comunidades de até 20.000 , possa ser construído o chamado aterro controlado (BRASIL, 1979). 
$\mathrm{O}$ aterro sanitário consiste na disposição de lixo no solo, de forma a minimizar danos ao meio ambiente e à saúde pública. Conforme a NBR 8419 (ABNT 1992) o aterro sanitário "é a técnica de disposição de resíduos sólidos urbanos no solo, sem causar danos à saúde pública e à sua segurança, minimizando os impactos ambientais, método este que utiliza os princípios de Engenharia para confinar o lixo à menor área possível e reduzi-lo ao menor volume permissível, cobrindo-os com uma camada de terra na conclusão de cada jornada de trabalho, ou a intervalos menores, se necessário". No aterro sanitário, devem ser previstos os sistemas de drenagem superficial das águas de chuva, de drenagem de gás, de drenagem sub-superficial do líquido percolado, bem como seu tratamento.

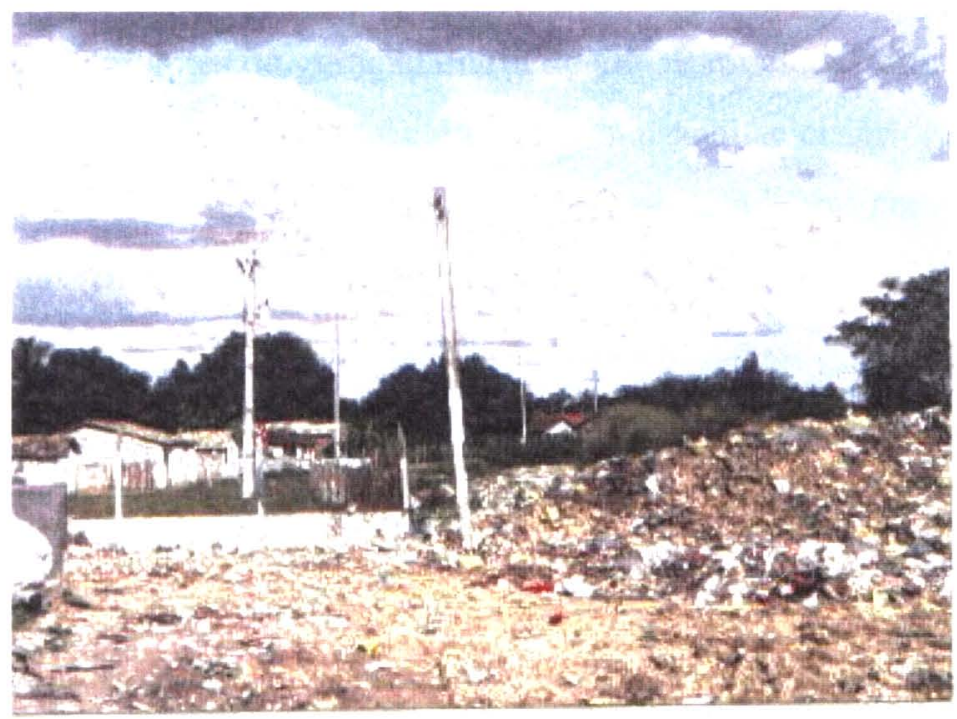

Figura 1 - Lixão a céu aberto ao lado da Usina de Reciclagem e Compostagem do município de Sapeaçu - BA.

Segundo JARAMILO (1994), as desvantagens do aterro sanitário são a dificuldade de aquisição do terreno para esse fim, devido à oposição por parte do público, o risco de ser transformado em lixão a céu aberto pela descontinuidade das administrações municipais, apresentando eventual contaminação das águas subterrâneas e superficiais, se não houver uma monitorização adequada durante a fase de sua operação e encerramento.

$\mathrm{O}$ aterro controlado apresenta-se como uma alternativa para comunidades de menor porte porque os custos de implantação e operação são menores, uma vez que 
podem ser utilizados equipamentos simplificados para a operação, ou serem operados manualmente. Para implantação do aterro controlado deve-se adotar criteriosa análise da localização do terreno em relação ao solo e aos recursos hídricos. Também devem ser previstos a drenagem de águas pluviais e um plano de inspeção da área de influência do aterro controlado com vistas ao controle da poluição ambiental (NBR $8849,1985)$.

A resolução CONAMA $n^{\circ}$. 308/2002, considerando as dificuldades dos municípios de pequeno porte para implantação e operação de sistemas de disposição final de resíduos, na forma em que são exigidos no processo de licenciamento ambiental, estabeleceu critérios para esse licenciamento. A resolução considera município de pequeno porte, ou associações de municípios aqueles com população urbana de até 30.000 habitantes ou geração diária de até 30 toneladas/dia. Neste caso, a implantação do sistema de disposição final deve adotar análise criteriosa do terreno em relação ao solo e aos recursos hídricos. Devem, também, ser previstos a drenagem das águas pluviais, a coleta, destinação e tratamento adequado dos percolados e, quando necessário, a queima dos efluentes gasosos.

\subsubsection{Gerenciamento dos resíduos sólidos urbanos}

Pelo exposto, os resíduos sólidos após sua geração, podem ser manejados de diversas formas, conforme abaixo relacionado em ordem crescente de benefícios sanitários, sociais, ambientais, ecológicos e educacionais que o gerenciamento proposto proporcionará.

\section{a. Gerenciamento insustentável e sanitariamente inadequado}

Coleta e disposição final no solo a céu aberto (lixões), em áreas alagadas ou nos corpos d'água. Essa prática inadequada, utilizada majoritariamente no Norte e Nordeste do Brasil, deve ser banida, devido aos problemas ambientais e de saúde pública que proporciona.

\section{b. Gerenciamento sanitariamente adequado e ambientalmente insustentável}

Coleta e disposição final em aterro sanitário/controlado. Nesta forma de manejo dos resíduos urbanos, há uma minimização dos impactos ambientais e na 
saúde pública. No entanto, é ambientalmente insustentável porque não há limitação do uso dos recursos naturais.

c. Gerenciamento sanitariamente adequado com envolvimento de geradores potenciais de resíduos sólidos

Coleta diferenciada dos resíduos orgânicos e de outros recicláveis provenientes de geradores potenciais (hotéis, feiras-livres, restaurantes) e encaminhamento para a compostagem e para indústrias recicladoras e disposição final em aterros sanitários/controlados.

d. Gerenciamento sanitariamente adequado e ambientalmente sustentável sem envolvimento comunitário

Coleta e encaminhamento para usinas de triagem e compostagem onde é realizada a separação manual dos resíduos possíveis de ser reciclados, para o seu encaminhamento a indústrias recicladoras, compostagem dos resíduos orgânicos triados, e o restante depositado em aterro sanitário/controlado. Neste modelo, não há envolvimento comunitário.

\section{e. Gerenciamento sanitariamente adequado e ambientalmente sustentável com envolvimento comunitário}

Segregação na fonte geradora, coleta seletiva, encaminhamento dos resíduos recicláveis para as indústrias recicladoras, compostagem dos resíduos orgânicos separados e o restante depositado em aterro sanitário/controlado.

\section{f. Gerenciamento dos resíduos sólidos para sociedades sustentáveis}

Além da segregação na fonte geradora, coleta seletiva, encaminhamento dos resíduos recicláveis a indústrias recicladoras, compostagem dos resíduos orgânicos, e o restante depositado em aterro sanitário/controlado, deve incorporar reflexões sobre a forma de produção e consumo, presente na sociedade. Segundo SPOSSATI (2001), essa reflexão passa pelo "exame dos chamados comportamentos destrutivos, da predatória sociedade industrial e pós-industrial, também deve ser instalada uma concepção preventiva e preservadora que repense os usos e costumes da 
modernidade e seu impacto no futuro da vida humana e da natureza". Este gerenciamento deve estar fundamentado nos conceitos de sustentabilidade, ambientalismo, participação social, tecnologias apropriadas e, também, no que foi preconizado no Tratado sobre Resíduos obtido no Fórum das ONGs e Movimentos Sociais (1992) e na Agenda 21 (1992).

Os princípios são:

- Princípio de precaução na adoção de qualquer nova tecnologia para a produção de produtos para o consumo, pois é mais sábio prevenir de que remediar os impactos negativos sobre o ambiente e sobre a saúde humana;

- Princípio da responsabilidade social tanto do ponto de vista do empresário (extração da matéria prima, produção, circulação, uso e descarte de seus produtos) como do usuário ao comprar e descartar;

- Princípio da inclusão social, o que implica na redução da pobreza através da geração de emprego e renda. Também a inclusão dos catadores de lixo no processo de gerenciamento dos resíduos sólidos urbanos de forma a assegurar-lhes condições dignas de trabalho e de educação, sendo a escolha dessa profissão uma opção individual dos sujeitos;

- Princípio da participação popular na decisão sobre o gerenciamento de resíduos, não devendo estar sob controle exclusivo das autoridades;

- Princípio de responsabilidade política através da adoção de regulações nacionais e internacionais que objetivam implementar tecnologias limpas de produção, resgatar os resíduos na sua origem e eliminar as embalagens que não sejam biodegradáveis, reutilizáveis ou recicláveis, o que é um passo essencial para a criação de novas atitudes sociais e para prevenir os impactos negativos do consumismo ilimitado;

- Princípio de utilização de tecnologias apropriadas de processamento de resíduos de acordo com o contexto sócio-econômico, cultural e ambiental local;

- Princípio da sustentabilidade ecológica e ambiental que consiste na limitação do uso dos recursos não renováveis e na preservação da capacidade de autodepuração dos ecossistemas naturais e da biodiversidade $\mathrm{O}$ solo deve receber somente os resíduos não evitáveis, isto é, as atividades humanas 
devem gerar o mínimo possível de resíduo, reaproveitar o que for possível, processar, reciclar e tratar, antes da disposição final;

- Princípio da universalidade e eqüidade dos serviços públicos de coleta, tratamento e disposição final dos resíduos sólidos não evitáveis;

- Princípio da cooperação entre países, entre governo e diferentes segmentos e atores sociais; também solidariedade e parceria entre sociedade, universidades e movimentos sociais (entidades ambientalistas, ONGs, sindicatos, associações de classe e de moradores);

- Princípió da sustentabilidade econômico-financeira a qual inclui, conforme MORAES (2002), análises dos custos e possibilidades de recuperação dos mesmos, sistemas de taxas/tarifas/preços públicos baseados em custos reais (de forma a permitir a possibilidade de pagamento) e sistemas possíveis de serem mantidos.

- Princípio do conhecimento de todos os aspectos envolvidos na problemática dos resíduos sólidos, base fundamental para a efetivação de todos os princípios elencados acima. 


\subsubsection{Educação Ambiental no gerenciamento dos resíduos sólidos}

A participação da comunidade é imprescindível no gerenciamento do lixo urbano pois, diferentemente da utilização dos serviços de água e esgoto na qual o transporte se dá por gravidade ou por pressão, o lixo depende, na maioria de suas fases, das mãos do homem.

Portanto, a Educação Ambiental tem um papel importante na gestão dos resíduos sólidos. A Educação Ambiental pode ser praticada de diferentes maneiras dependendo da forma de proposta de gerenciamento dos resíduos sólidos. Baseada nos autores SORRENTINO (1995), CRESPO (1997) e QUINTAS (2000), a Educação Ambiental no gerenciamento do lixo pode estar inserida na corrente da gestão ambiental, ou seja, orientada para a mudança de comportamento ou visando a resultados. As estratégias empregadas terão como objetivo levar a comunidade: a segregar o lixo na fonte geradora, acondicioná-lo de forma diferenciada, participando da coleta seletiva, entregá-lo em postos de recebimento desses materiais, evitar desperdícios, reaproveitar seus resíduos sólidos na residência (aproveitamento de vasilhames, compostagem doméstica) e zelar pela limpeza de sua rua. Da mesma forma, a sociedade deve ter sua participação nas tomadas de decisão quanto aos aspectos de escolha de alternativa para o gerenciamento dos resíduos sólidos: participando da escolha da área para construção de aterro sanitário, da implementação de indústrias recicladoras locais ou na exportação do lixo reciclável, da implantação de sistemas de tratamento de resíduo sólidos (compostagem, incineração). Estas estratégias educacionais devem estar presentes em todas as formas de gerenciamento descritas anteriormente.

O quadro 4 resume o comportamento esperado da comunidade nas diversas fases do sistema de gerenciamento de resíduos sólidos quando as estratégias educacionais estão pautadas na mudança de comportamento.

A Educação Ambiental para mudança de sensibilidade na construção de sociedades sustentáveis deve promover o pensamento sistêmico e uma abordagem holística dos problemas sociais, econômicos e ambientais, e proporcionar a "construção da subjetividade coletiva para além do individual, de um desejo novo para a construção de um novo paradigma. A construção de um desejo novo é fundamental, pois, se não ocorre a incorporação do desejo no plano da subjetividade, 
a alteração pretendida não alcança o imaginário coletivo, o desejo da sociedade e, conseqüentemente, torna-se descartável" (SPOSATI 2001, p.25). Acredita-se que isso deva ser o principal motivo da interrupção de muitos projetos de coleta seletiva e usinas de reciclagem implantadas no Brasil.

Quadro 4 Comportamento esperado da comunidade no gerenciamento dos resíduos sólidos urbanos quando as estratégias educacionais estão pautadas na mudança de comportamento

\begin{tabular}{|c|c|c|}
\hline FASE DO SISTEMA & & $\begin{array}{c}\text { COMPORTAMENTO } \\
\text { ESPERADO } \\
\end{array}$ \\
\hline GERAÇÃO & $\leftarrow$ Educação Ambiental & $\begin{array}{l}\text { Evitar o desperdício; } \\
\text { reaproveitamento dos } \\
\text { resíduos no domicílio. }\end{array}$ \\
\hline ACONDICIONAMENTO & $\leftarrow$ Educação Ambiental & $\begin{array}{l}\text { Segregação na fonte para } \\
\text { a coleta seletiva e/ou } \\
\text { encaminhar para locais } \\
\text { de } \\
\text { voluntário. }\end{array}$ \\
\hline COLETA & $\leftarrow$ Educação Ambiental & $\begin{array}{l}\text { Respeito ao horário de } \\
\text { coleta; acondicionamento } \\
\text { adequado. }\end{array}$ \\
\hline $\begin{array}{c}\text { TRATAMENTO } \\
\text { (PROCESSAMENTO) }\end{array}$ & $\begin{array}{l}\leftarrow \text { Educação Ambiental } \\
\rightarrow \text { Instrumentos de } \\
\text { educação ambiental }\end{array}$ & $\begin{array}{l}\text { Participação na definição } \\
\text { da forma }\end{array}$ \\
\hline DISPOSIÇÃO FINAL & $\leftarrow$ Educação Ambiental & $\begin{array}{l}\text { Participação na escolha } \\
\text { da área do aterro } \\
\text { sanitário. }\end{array}$ \\
\hline
\end{tabular}




\section{OBJETIVOS}

\subsection{Objetivo Geral}

Descrever e avaliar três experiências de Educação Ambiental voltadas para o gerenciamento dos resíduos sólidos urbanos, visando contribuir na formulação de subsídios metodológicos para projetos de Educação Ambiental relacionados a resíduos sólidos urbanos.

\subsection{Específicos}

- Verificar quais elementos de sensibilização e quais atividades implementadas nos distintos projetos estudados, que atingiram significativamente, a comunidade na mudança de percepção sobre a questão do lixo.

- Diagnosticar os aspectos que facilitaram ou dificultaram o processo participativo proposto nos projetos estudados.

- Analisar de que forma as práticas de Educação Ambiental, tendo como tema os resíduos sólidos urbanos, instigaram a leitura da problemática ambiental local.

- Correlacionar aspectos comuns aos programas estudados que levaram à participação da comunidade na coleta seletiva de lixo. 


\section{METODOLOGIA}

\subsection{Método de Investigação}

A pesquisa refere-se a um estudo descritivo, de caráter exploratório, para avaliar três experiências de Educação Ambiental voltadas para o gerenciamento dos resíduos sólidos urbanos, objeto de estudo dessa pesquisa. A metodologia da pesquisa qualitativa apresentou-se como abordagem adequada para contemplar os aspectos de caracterização das realidades locais a serem estudadas que a teoria da representação social permite abranger. Conforme MINAYO (1999, p.10), "as metodologias da pesquisa qualitativa são aquelas capazes de incorporar a questão do significado e da intencionalidade como inerentes aos atos, às relações e às estruturas sociais, sendo essas últimas tomadas, tanto no seu advento, quanto na sua transformação, como construção humana significativa". Como as questões ambientais são complexas e integradas por processos de ordem natural, técnica, social e educacional, não podem ser absorvidas por uma disciplina o que, segundo LEFF (2000, p. 171), deve "levar a uma tematização diferenciada do campo ambiental e a novas estratégias para a articulação de ciências e saberes. $O$ saber ambiental privilegia o qualitativo frente ao quantificável da realidade social".

$\mathrm{Na}$ avaliação dos programas de Educação Ambiental, foram observadas as questões subjetivas e objetivas presentes no tema da pesquisa. Para as primeiras questões utilizaram-se para a coleta de dados: entrevistas, observações de campo e análise do material impresso utilizado na sensibilização. Para as questões objetivas buscou-se quantificar os principais indicadores de geração de resíduos sólidos em cada localidade.

\subsection{Cenário da pesquisa}

Considerando-se a importância da participação da comunidade no manejo, ambientalmente correto dos resíduos sólidos urbanos, e o desafio de responder como se processa a ação transformadora dos indivíduos proposta pela Educação Ambiental, 
decidiu-se estudar três programas de Educação Ambiental voltados para o gerenciamento dos resíduos sólidos em curso nos seguintes locais:

a. Campus da Universidade Estadual de Feira de Santana, localizada na cidade de Feira de Santana, Bahia. Neste local desenvolve-se, desde 1992, o "Projeto Coleta Seletiva e Reaproveitamento do Lixo gerado no Campus";

b. Arraial de São Francisco da Mombaça, distante $6 \mathrm{~km}$ do município de Conceição do Almeida e $180 \mathrm{~km}$ de Salvador, Bahia. O Arraial é uma pequena localidade onde vive uma população de 700 pessoas, e a Associação Comunitária local desenvolve, desde 1995, o "Projeto Terra Viva - o que queremos?" em que uma das linhas de ação é resolver o problema do lixo produzido no local;

c. Município de Mucugê, Bahia, localizado na Chapada Diamantina, a $420 \mathrm{~km}$ de Salvador. O município possui 3.048 habitantes na zona urbana $\mathrm{A}$ Prefeitura local implantou, em parceria com a Companhia de Desenvolvimento e Ação Regional (CAR), durante o ano de 1999, a coleta seletiva dos resíduos sólidos urbanos e a Usina Simplificada de Reciclagem e Compostagem do Lixo.

O motivo da escolha dessas três experiências foi porque se intencionava estudar programas de Educação Ambiental voltados para o gerenciamento de resíduos sólidos urbanos que estivessem sendo desenvolvidos no Estado da Bahia por um período de tempo, para fornecer os dados pretendidos. Além disso, como a pesquisadora desenvolve suas atividades profissionais na área em foco em Universidade desse Estado e, também, por estar envolvida diretamente em duas dessas experiências (UEFS e Mombaça), a pesquisa despenderia menores recursos financeiros para deslocamentos, bem como, haveria maior facilidade no acesso aos dados.

Também pesou na escolha, o fato desses programas serem desenvolvidos por diferentes setores da sociedade (universidade, órgãos governamentais e associação comunitária), o que poderia proporcionar, à pesquisa, aspectos diferenciados na sua concepção e implementação e, conseqüentemente, nos sujeitos atingidos por tais programas. 


\subsection{Sujeitos Participantes}

$\mathrm{Na}$ representação social o objetivo é resgatar o discurso dos indivíduos, considerando que neste tipo de pesquisa "a quantidade de pessoas não é uma variável crítica.... por isso deve-se trabalhar com amostras intencionais e com critérios eminentemente qualitativos de coleta e processamento de dados" (LEFÈVRE F e LEFÈVRE A 2000, p. 35). Desse modo, a amostra dessa pesquisa foi intencional, ao se realizarem, em cada uma das três localidades entrevistas, com pessoas representativas da comunidade que tivessem "a possibilidade de enxergar a questão sob várias perspectivas, pontos de vista e de observação" (MINAYO 1999, p. 103). Encerravam-se as entrevistas com sujeitos integrantes de cada comunidade em estudo quando as informações se tornavam repetitivas.

A entrevista só foi realizada com o livre consentimento dos sujeitos, que assinaram um termo, cujo modelo se encontra no Anexo 05.

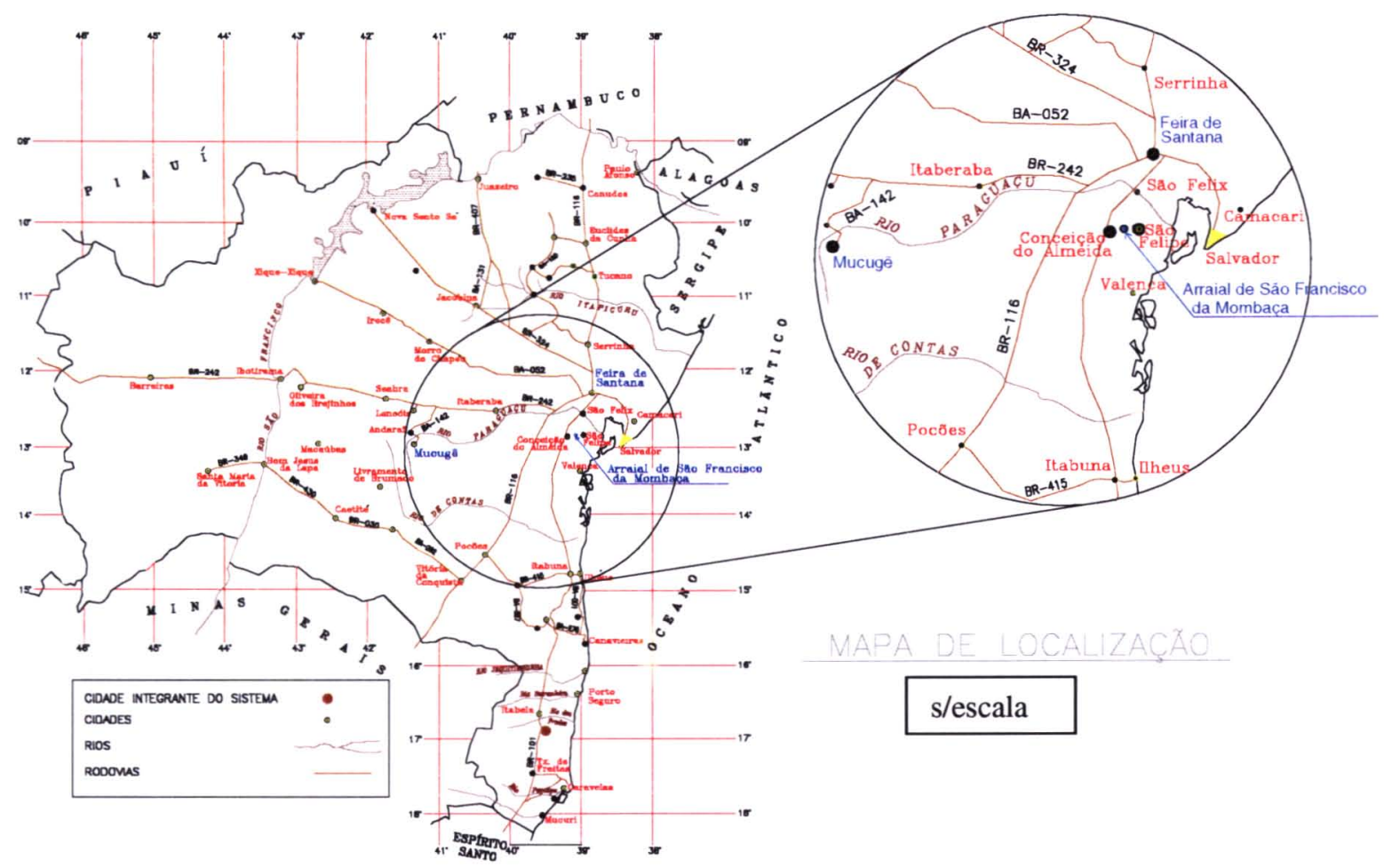

Figura 2 - Mapa dos locais onde estão em curso os programas de Educação Ambiental estudados. 


\subsubsection{Característica da população pertencente à comunidade}

universitária da UEFS

As entrevistas com os indivíduos pertencentes à comunidade universitária foram realizadas no período de fevereiro a março de 2002. Procurou-se entrevistar professores e funcionários que estavam trabalhando na Universidade há pelo menos dez anos, uma vez que as atividades relacionadas à construção, implementação e desenvolvimento do projeto se iniciaram nesse período de tempo.

Foram entrevistados cinco professores, sendo dois do sexo masculino e três do sexo feminino, com idades variando de 34 a 51 anos. Os professores entrevistados estavam em atividade na UEFS num período de 10 a 24 anos e pertencentes à diferentes Departamentos.

Nove alunos representaram esse segmento da comunidade universitária e estavam cursando o último semestre dos cursos de: Geografia, Letras, Odontologia, Ciências Biológicas, Pedagogia, Direito, Engenharia Civil e Matemática, sendo sete do sexo feminino e dois do sexo masculino, com idade variando de 21 a 31 anos. $\mathrm{O}$ tempo de estudo na UEFS variou de 7 a 18 semestres.

Os funcionários entrevistados, um homem e três mulheres, trabalham na UEFS em diferentes funções, num período de 10 a 26 anos, e possuem idade variando entre 39 e 61 anos.

Também foi entrevistada uma professora que fez parte do início do projeto e um aluno estagiário do projeto analisado. As falas desses sujeitos foram utilizadas, ao longo da pesquisa, para ilustrar fatos considerados relevantes.

\subsubsection{Característica da população pertencente à comunidade do Arraial} de São Francisco da Mombaça.

No Arraial de São Francisco da Mombaça foram entrevistadas, durante o período de fevereiro a abril de 2002, 11 pessoas, com idade variando de 16 a 53 anos, sendo 8 mulheres e 3 homens. Nesse universo de pessoas entrevistadas estão: professoras da escola local, integrantes da Associação Comunitária do Arraial de São 
Francisco da Mombaça, pais de alunos e moradores da localidade. Somente dois dos entrevistados não nasceram na localidade, contudo moram lá há mais de 17 anos.

A coordenadora do projeto foi também entrevistada e sua fala não integrou os discursos do sujeito coletivo, mas foi utilizada para complementar dados sobre o projeto.

\subsubsection{Característica da população pertencente à comunidade de Mucugê}

As entrevistas para se obter a representação social dos sujeitos alvos do projeto de Educação Ambiental, desenvolvido no município de Mucugê, foram realizadas na sede desse município, no mês de maio de 2002, com treze mulheres e quatro homens, com idade variando de 18 a 60 anos. Dentre este universo de pessoas estavam: estudantes, professores, doméstica, donas de casa, comerciante, gari, gerente de hotel, garçom, enfermeira, agente comunitário, motorista, balconista e guia turístico. Indivíduos representantes dessas classes de moradores é que formariam os grupos para a composição da rede de mobilização comunitária, conforme citado pela coordenadora do projeto de Educação Ambiental desenvolvido para o relançamento da usina. O tempo de residência dos entrevistados em Mucugê variou de 4 a 22 anos.

Entrevistou-se também: a coordenadora geral do projeto da Usina Simplificada de Reciclagem e Compostagem, a coordenadora do Projeto de Educação Ambiental, ambas técnicas da CAR, e o professor coordenador das atividades de Educação Ambiental realizadas pela escola, o qual mora em Mucugê. As visões dessas pessoas ilustraram e fundamentaram questões relacionadas ao projeto. 


\subsection{Passos Metodológicos}

\subsubsection{Pesquisa bibliográfica}

Levantamento e leitura de materiais relacionados aos objetivos da pesquisa para subsidiar os conceitos fundamentais e a análise dos resultados. Entre os temas pesquisados estão: Educação Ambiental, Resíduos Sólidos, Avaliação de Projetos, Desenvolvimento Sustentável.

\subsubsection{Pesquisa documental}

Após análise dos documentos disponíveis em cada experiência, selecionaramse intencionalmente, aqueles que pudessem reconstruir o passado das experiências como diagnósticos locais, projetos, relatórios e artigos técnicos. Também foi importante selecionar o material utilizado nas campanhas educacionais, como cartilhas, folder, fotos de cartazes, entre outros. Buscou-se também ter acesso às planilhas que continham dados sobre a quantificação e qualificação dos resíduos sólidos gerados em cada local estudado.

Esses documentos subsidiaram a fase descritiva dos programas, como também o levantamento dos indicadores de geração de resíduos sólidos em cada localidade. Serviram também, para explorar os aspectos importantes para a avaliação encontrados nos materiais escritos e fotográficos utilizados na sensibilização da comunidade.

\subsubsection{Entrevista individual}

Para se obter a representação social dos diversos atores envolvidos, o instrumento de coleta de dados utilizado foi a entrevista semi-estruturada, gravada magneticamente e, posteriormente, transcrita integralmente. $O$ roteiro da entrevista é mostrado no Anexo 4. A entrevista foi pré-testada antes de sua aplicação definitiva. Pela representação social, foi explorado um dos aspectos subjetivos: como os 
programas de Educação Ambiental repercutiram nos diversos atores sociais atingidos pela ação. Segundo MINAYO (1995 p. 109), “o que torna a entrevista um instrumento privilegiado de coleta e informação para as ciências sociais é a possibilidade de a fala ser reveladora das condições estruturais, dos sistemas de valores, normas e símbolos. A entrevista transmite, através de um porta voz, as representações de grupos determinados em condições históricas, sócio-econômicas e culturais específicos".

Conforme ROCHE (2002), GIL (1991) e TRIVINÕS (1987), algumas questões podem 'ser levantadas quanto à utilização da entrevista como forma de coleta de dados: a falta de motivação do entrevistado para responder as perguntas formuladas; a inadequada compreensão dos significado das perguntas; o fornecimento de respostas falsas, determinadas por razões conscientes ou inconscientes; e, a influência exercida pelo aspecto pessoal do entrevistador sobre o entrevistado. $\mathrm{Na}$ pesquisa, teve-se o cuidado de cruzar os dados obtidos nas entrevistas com aqueles obtidos nos documentos escritos, nos depoimentos dos responsáveis pelos projetos e na observação de campo.

O roteiro das entrevistas foi construído a partir de três eixos centrais, citados no item 1.3.2: a construção do conhecimento, o desenvolvimento de valores e atitudes, o comportamento e a ação.

\subsubsection{Observação de campo não estruturada}

Esta fase teve como objetivo o olhar do pesquisador direcionado para o problema a ser estudado. Por meio de conversas e relatos informais, visitas a residências para verificar o manejo do lixo, participação em eventos proporcionados pelos projetos, observaram-se os diversos fatores relacionados aos objetivos e ao alcance da pesquisa. Foi observada também a paisagem de cada localidade, buscando-se as possíveis mudanças ocorridas devido a implementação do programa/projetos estudados. 


\subsection{Organização e Análise dos Dados}

Para a organização e análise dos dados das entrevistas utilizou-se a metodologia proposta por LEFÈVRE F e LEFÈVRE A (2000). Para a organização dos dados, utilizaram-se estas três figuras metodológicas: Idéia Central (IC), Expressões-Chave (EC) e o Discurso do Sujeito Coletivo (DSC).

A Idéia Central é entendida como afirmações que permitem traduzir o essencial do conteúdo discursivo explicitado pelo sujeito em seu depoimento. As Expressões-chavè são constituídas por transcrições literais de partes dos depoimentos, que permitem o resgate do essencial do conteúdo discursivo dos segmentos em que se divide o depoimento (LEFÈVRE E LEFÈVRE 2000, p. 18).

Para cada questão formulada nas entrevistas procedeu-se a leitura atenta das respostas dos entrevistados, destacando-se as expressões-chave que, em seguida, foram agrupadas em um conjunto homogêneo. Desse grupo de expressões-chave, extraídas das respostas, retirou-se a Idéia Central de forma que traduzisse o essencial do conteúdo discursivo explicitado pelos sujeitos em seu depoimento. Nos discursos referente à questão 1 , do projeto desenvolvido no Arraial de São Francisco da Mombaça, extraíram-se, das entrevistas, as Idéias Centrais de forma a dar uma sequiência lógica ao resgate da história do projeto.

Nesta pesquisa, as Expressões-Chave foram as formadoras dos Discursos do Sujeito Coletivo. Assim, conforme os mesmos autores, "com os pedaços de discursos individuais, reconstroem-se os discursos sínteses que expressam um dado pensar ou a representação social sobre o fenômeno".

Cada um dos sujeitos estão identificados ao longo dos discursos por uma letra e um número. O número representa um dos entrevistados em cada localidade, sendo possível identificá-lo ao longo de todos os discursos do sujeito coletivo. A letra representa o sujeito entrevistado (S). No caso da UEFS o professor foi identificado pela letra "P", aluno pela letra "A" e o funcionário pela letra " $F$ ".

A representação social sobre os programas de Educação Ambiental utilizou o método da análise do discurso presentes nas respostas obtidas nas entrevistas realizadas. "Porque as pessoas são diferentes - e ao mesmo tempo as mesmas - a ação e o discurso tornam-se necessários: se nós fôssemos todos idênticos, não 
haveria necessidade de comunicação ou da ação sobre o que nunca varia; se nós não tivéssemos nada em comum, a fala perderia seu próprio fundamento e a ação não justificaria a si mesmo" (JOVCHELOVITH 1998, p.67). 


\section{AVALIAÇÃo dOS PROGRAMAS DE EDUCAÇÃo AMBIENTAL}

\subsection{Programa de Educação Ambiental na Universidade Estadual de Feira de Santana}

\subsubsection{Caracterização da Universidade}

A Universidade Estadual de Feira de Santana (UEFS) está localizada à margem da Rodovia Transnordestina, Br 116 - km 3, na cidade de Feira de Santana, Estado da Bahia, a uma distância aproximada de 3 quilômetros do centro da cidade e 108 quilômetros de Salvador, capital do Estado (Figura 3). A população do município de Feira de Santana, segundo censo de 2000, é de 480.692 habitantes, dos quais $89,7 \%$ vivem na área urbana e $10,24 \%$ na zona rural (UEFS 2001).

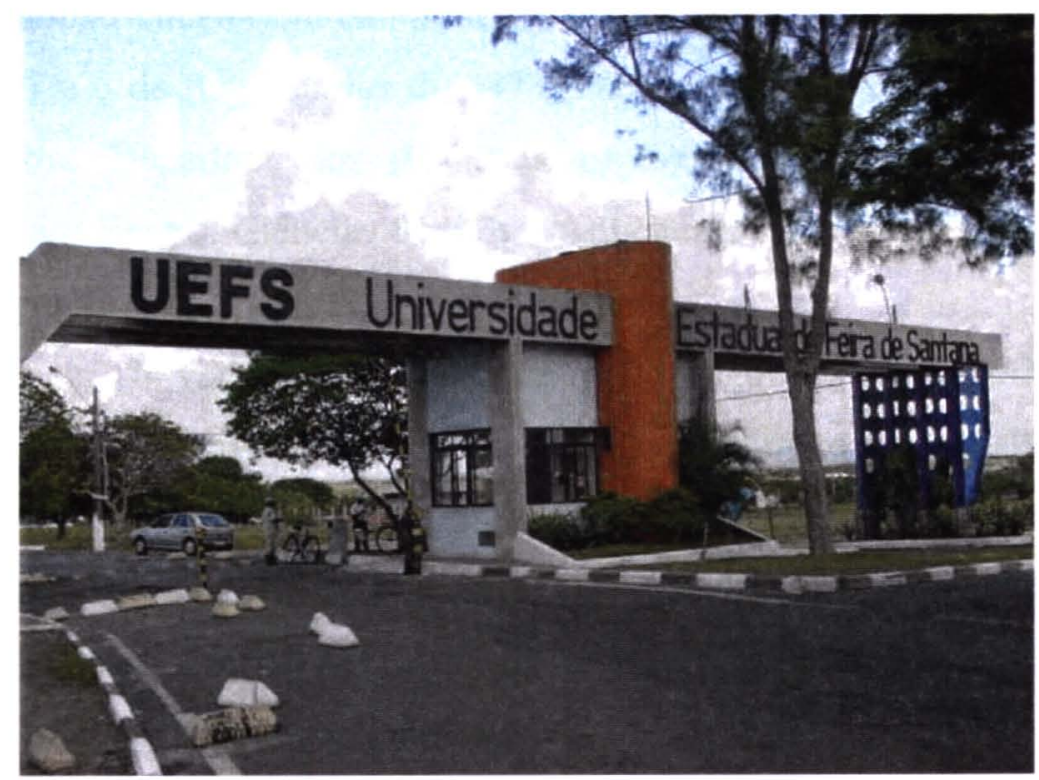

Figura 3 - Vista do pórtico de entrada da Universidade Estadual de Feira de Santana. 
O município de Feira de Santana situa-se na região do Paraguaçu, entre o Recôncavo e os tabuleiros semi-áridos do Nordeste, sendo que $96 \%$ do seu território está inserido no polígono das secas. O município é considerado o principal entroncamento rodoviário do Norte e Nordeste, localização privilegiada que representa um dos fatores de seu desenvolvimento, exercendo influência sobre uma vasta região, como centro de convergência e de escoamento da produção, como distrito geoeducacional e pólo de valores ideológico-culturais e como ponto de atração de migrantes. Esta influência cresce a partir da implantação da Universidade em maio de 1976'(Decreto Federal nº.77.496, de 27/04/1976), a qual, através de suas ações extensionistas, atinge, atualmente, 150 municípios do Estado da Bahia (UEFS 2001).

A missão da Universidade, descrita no Planejamento Estratégico para 2000 a 2004, é "produzir e difundir o conhecimento, assumindo a formação integral do homem e de profissionais cidadãos, contribuindo para o desenvolvimento regional e nacional, promovendo a interação social e a melhoria da qualidade da vida, com ênfase na região do semi-árido".

Atualmente, a Universidade tem 6.581 alunos matriculados em 22 cursos de graduação e 1.058 matriculados em cursos de pós-graduação latu sensu. O número de docentes é de 677 e o de funcionários de 447 (UEFS em dados, 2001). A UEFS é composta por nove Departamentos (Ciências Biológicas; Ciências Humanas e Filosóficas; Ciências Exatas, Ciências Sociais e Aplicadas; Educação; Física; Letras e Artes; Tecnologia; Saúde).

O campus da Universidade é composto pelos seguintes prédios: Módulos administrativos (MA), teóricos (MT) e práticos (MP) em número de sete; Pavilhões de aulas teóricas (PAT) em número de seis; Laboratórios (LAB) em número de quatro; Centros Administrativo Universitário (CAU) em número de três; Biblioteca e Prédio do CPD; Reitoria; Creche; Escola básica; Parque esportivo; Garagem, Prédio da Manutenção, Casa do Sertão, Cantinas, Residência Universitária, Prédio da Equipe de Educação Ambiental, Estação Climatológica. 


\subsubsection{Descrição do Projeto Coleta Seletiva e Reaproveitamento do Lixo gerado no campus da Universidade Estadual de Feira de Santana.}

O Projeto Coleta Seletiva e Reaproveitamento do Lixo gerado no campus da Universidade Estadual de Feira de Santana (UEFS) emergiu das recomendações aprovadas na plenária final do I Seminário de Educação Ambiental realizado na UEFS, em dezembro de 1990, promovido pelo Departamento de Ciências Exatas. Entre as recomendações propostas à Universidade, constavam a "criação de uma equipe interdisciplinar comprometida com a Educação Ambiental" e a "suspensão imediata da queima do lixo produzido no campus".

Em 12 de julho de 1991, conforme Portaria n ${ }^{\circ}$ 471/91, foi composta a Equipe de Educação Ambiental, na época formada pelos professores e respectivos departamentos: Maria de Fátima Hanaque Campos e Vicente Deoclesiano Moreira, Departamento de Ciências Humanas e Filosofia; Maria Ângela Alves do Nascimento, Departamento de Saúde; Maria de Fátima da Silva Nunesmaia, Departamento de Ciências Exatas; Nora Ney Alves dos Santos, Departamento de Biologia; Sandra Maria Furiam Dias, Departamento de Tecnologia. Esses professores foram indicados pelos seus respectivos departamentos, em resposta à correspondência, enviada pela professora do Departamento de Exatas, a qual solicitava nome de pessoas interessadas em trabalhos na temática ambiental. Em 1995, por meio da Portaria $1199 / 95$ de 28/12/1995, integraram a equipe as professoras Maria de Fátima Paixão e Marisa Oliveira Almeida do Departamento de Exatas e Maria do Socorro Costa São Mateus do Departamento de Tecnologia. Posteriormente integraram a Equipe os professores Áurea Chateaubriand Campos, Luiz Antonio Ferraro Junior e os professores visitantes Luciano Mendes Souza Vaz e Zanna Matos, do Departamento de Tecnologia. Estes novos professores integraram a EEA para atender demandas da sociedade, tais como o Curso de Especialização em Educação Ambiental para a Sustentabilidade e consolidar linhas de pesquisa e extensão em resíduos sólidos orgânicos.

No ano de 1991, iniciaram-se os estudos preliminares para a elaboração do projeto de manejo do lixo gerado no campus universitário. Esses estudos constaram 
de visitas e contatos com instituições e pessoas que trabalhavam com o manejo de resíduos sólidos de forma diferente da tradicional - coletar e dispor no solo.

“Eu lembro que, em 1991, já estava mais ou menos agendada a viagem que nós fariamos a vários estados do Brasil que tinham projetos de reciclagem $e$ gerenciamento de lixo, para ver, "in loco", essas experiências e transplantá-las, de alguma forma para a Universidade. Eu lembro que, nesse ínterim, uma colega deu a identificação do primo dela, o Engenheiro Penido, que estava na Secretaria no Rio de Janeiro e que tinha um "know-how" enorme sobre a parte de coleta seletiva $e$ sobre a usina que estava em funcionamento naquela cidade. Tínhamos, também, outros contatos em São Paulo, Espírito Santo e Belo Horizonte. A partir daí, a gente montou este cronograma de visitas, o Reitor, professor Josué, deu total apoio, com passagens e diárias e, então, nós viajamos. Sem dúvida o Engenheiro Penido foi o que mais ajudou na estruturação do projeto. Ele conversou muito com a gente, foi muito solícito e deu sugestões fantásticas de como montar esta coleta seletiva. A questão da reciclagem e do reaproveitamento era algo já de conhecimento europeu. A implantação da coleta era o ponto crucial e, digamos, completamente novo, era pegar experiências de grandes cidades e colocá-las em nível micro, num campus de uma Universidade. A questão da implantação da coleta seletiva era o mais complicado e, neste sentido, Penido ajudou muito, como dimensionar os coletores de lixo, como dimensionar a coleta. Penso que aí foi o ponto fundamental para montar este projeto. As outras experiências e as outras visitas, como a Espírito Santo mesmo, onde havia um projeto belíssimo da Prefeitura do PT, em que o lixão era em unna área de Manguezal onde foi implantada uma Usina de Reciclagem de Lixo, foram muito produtivas. Nesse Estado, havia um bom pessoal técnico que estava à frente e, por ser uma cidade de médio porte comparando-se com Rio e São Paulo, as coisas funcionavam um pouco melhor pois havia controle. Eu acho que essas visitas foram importantíssimas. Foi importante a ida a Belo Horizonte, onde uma artista plástica, que era quase uma empresária, tinha uma produção de reciclagem de papel e produzia em torno de 500 folhas por dia. Então, a gente tinha que avançar, para uma produção de médio porte. No que diz respeito à coleta seletiva, era reduzir essas experiências de metrópoles e grandes cidades para o ambiente de uma vila ou de um pequeno município e tentar adequar essas idéias dentro de uma realidade 
espacial que era a Universidade. Este foi, exatamente, o primeiro momento de dimensionar o projeto" (Professora integrante da EEA/UEFS).

A partir daí, foi realizado o "Ciclo do Lixo na UEFS" e a "Caracterização do lixo produzido na UEFS", visando conhecer os procedimentos adotados no manejo do lixo, desde sua geração, coleta interna nos locais de trabalho, salas de aula e laboratórios, seu acondicionamento, coleta externa e destinação final. A caracterização física dos resíduos determinou as quantidades dos diversos tipos de resíduos descartados na Universidade. Os dados coletados subsidiaram o Projeto Coleta Seletiva e Reaproveitamento do Lixo gerado no campus da UEFS e foram importantes tanto para dar visibilidade ao projeto e ao trabalho da Equipe, como para buscar contribuições para sua execução.

Objetivos e linhas de ação do projeto Coleta Seletiva e Reaproveitamento do Lixo gerado no Campus

Seguem abaixo os objetivos e as linhas de ação descritos no "Projeto Coleta Seletiva e Reaproveitamento do Lixo gerado no campus UEFS" (NUNESMAIA et al., 1992).

Objetivos: implantar uma experiência - piloto de coleta seletiva e reaproveitamento do lixo produzido no Campus da Universidade Estadual de Feira de Santana, através da Educação Ambiental", desenvolver pesquisas e atividades de extensão sobre a questão de resíduos sólidos, capacitar recursos humanos; comercializar o material separado e/ou reciclado; orientar a comunidade quanto ao manejo correto do lixo, e suas implicações na saúde da população, tornar o campus um local mais bonito e agradável. 
Para a concretização desses objetivos, foram propostas quatro linhas de ação contempladas pelos seguintes projetos:

Projeto Coleta Seletiva com o objetivo de implantar a coleta seletiva no campus, a qual consiste na separação do lixo em sua fonte geradora, visando a um ambiente saudável e à tomada de consciência de que o lixo pode ser reaproveitável;

Projeto Oficina Artesanal de Papel que visava à implantação de oficina para reciclagem de papel, com o intuito de divulgar e conscientizar a comunidade sobre a importância da reutilização do papel;

Projeto Compostagem do Lixo Orgânico produzido no Campus que visava valorizar a fração orgânica dos resíduos e, também, ser uma forma de sensibilização dos administradores públicos e da comunidade sobre a questão de disposição final e aproveitamento de tais resíduos;

Projeto Caracterização Física do Lixo Gerado na UEFS com o objetivo de caracterizar (quantificar e qualificar) o lixo produzido no campus, a fim de projetar a sua coleta, seu transporte e o seu processamento, bem como verificar a sazonalidade dessa produção ao longo do tempo e as variáveis que pudessem influenciá-la.

\subsubsection{Gerenciamento do lixo da UEFS}

Para a implantação do projeto, foram adquiridos, pela Universidade, os equipamentos e os acondicionadores necessários para a coleta seletiva, os adesivos explicativos e os equipamentos para a instalação da oficina de papel e da compostagem. Foram realizadas obras civis tais como o pátio para a compostagem e as baias para o armazenamento do lixo reciclável, além da capacitação do pessoal de limpeza e campanhas de sensibilização da comunidade universitária (professores, alunos e funcionários da UEFS). A Universidade disponibilizou, à Equipe do projeto, uma área construída de $80 \mathrm{~m}^{2}$ para abrigar a oficina de papel, a área administrativa do projeto e área de recepção de visitantes (Figura 4A). 
$\begin{array}{ll}\text { A } & \text { B }\end{array}$

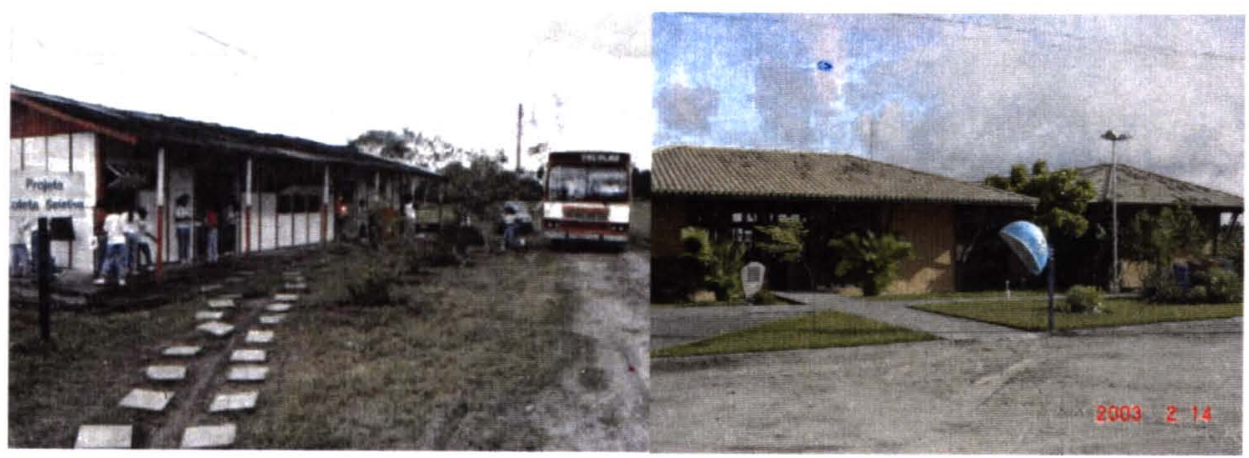

Figura 4- Sedes da Equipe de Educação Ambiental: (A) Antiga sede (B) Nova sede inaugurada em outubro de 1997.

“...e aí precisávamos de um espaço, onde nos reunirmos, para começar a trabalhar, trazer pessoal que pudesse nos ajudar. Foi quando descobrimos que havia um barracão próximo à quadra de esporte. Era um barracão que servia como depósito de peças, de equipamentos sem uso e, a princípio, houve até uma certa resistência com relação a funcionários que ficavam lá trabalhando porque era uma idéia completamente nova, inusitada, ninguém jamais tinha ouvido falar. Houve momentos em que parecíamos umas sonhadoras, um pouco fora do contexto e aí fizemos todo um esforço para conseguir este espaço. Houve também o apoio para reservar aquele espaço de trabalho e, daí, o fomos montando. Precisávamos de cadeira, mesa, máquina e, fomos providenciar um funcionário para nos ajudar, bem como bolsistas, junto à pró-reitoria de extensão. Enfim, passamos até 1992 trabalhando nesta parte de estruturação, para iniciar o funcionamento do projeto. Acho que foi muito forte em nós três este desejo em tocar um projeto que parecia ser algo muito novo, pioneiro, e com um nível muito grande de dificuldades. Então, esta fase inicial foi difícil - implantar um projeto, dimensionar o funcionamento nos setores, esquematizar como seria a coleta e, também, de criar uma infraestrutura desse espaço que nós precisávamos para nos reunir, para trabalhar, para trocar idéias. A atenção ficou voltada para estes dois espaços: o campus universitário, 
instalar, implantar esse projeto e iniciar o seu funcionamento e o espaço do barracão, que era a nossa sede" (Professora integrante da EEA/UEFS).

Com a infra-estrutura instalada, em outubro de 1992, foi implantado o projeto e o manejo do lixo, que até essa data, consistia em coleta e queima a céu aberto, passou a ser realizado mediante coleta seletiva, armazenamento dos recicláveis com demanda de mercado na região (papel/papelão, vidro, metal, plástico), oficina de reciclagem artesanal de papel e compostagem do resíduo orgânico. A compostagem foi implantada em 1994, (Figuras 5 D, E e F).

Um dos princípios fundamentais do gerenciamento dos resíduos sólidos proposto foi a sua separação na fonte geradora e seu descarte em lixeiras identificadas por cor e pelo adesivo explicativo referente ao tipo de resíduo a ser acondicionado (Figura 5 A e B). Essa separação consistiu em descartar o papel, na lixeira azul, o plástico, na vermelha, o metal, na amarela, o vidro, na verde e o lixo não reciclável e sem mercado na região, denominado de aterro, deveria ser descartado na lixeira de cor abóbora. Acondicionadores na cor marrom, para o resíduo orgânico, foram instalados somente nas cantinas por serem esses locais os seus maiores geradores. Nas cantinas, também foram instalados acondicionadores de maior porte para armazenar, temporariamente, o papel, metal, vidro, plástico e o lixo aterro (Figura 5 E). A coleta, inicialmente, era realizada manualmente por dois funcionários da UEFS. Um deles coletava o papel das lixeiras espalhadas pelo campus e o transportava até uma baia de armazenamento. Esse funcionário também era responsável pela coleta, transporte e processamento do resíduo orgânico e da coleta do vidro, metal e plástico colocados nas lixeiras maiores junto às cantinas. $\mathrm{O}$ lixo aterro era coletado das respectivas lixeiras, pelo segundo funcionário, e encaminhado até uma policaçamba estacionada em local estratégico. Mais tarde, foi contratado mais um funcionário para trabalhar, especificamente, com a coleta, transporte e processamento dos resíduos orgânicos. 

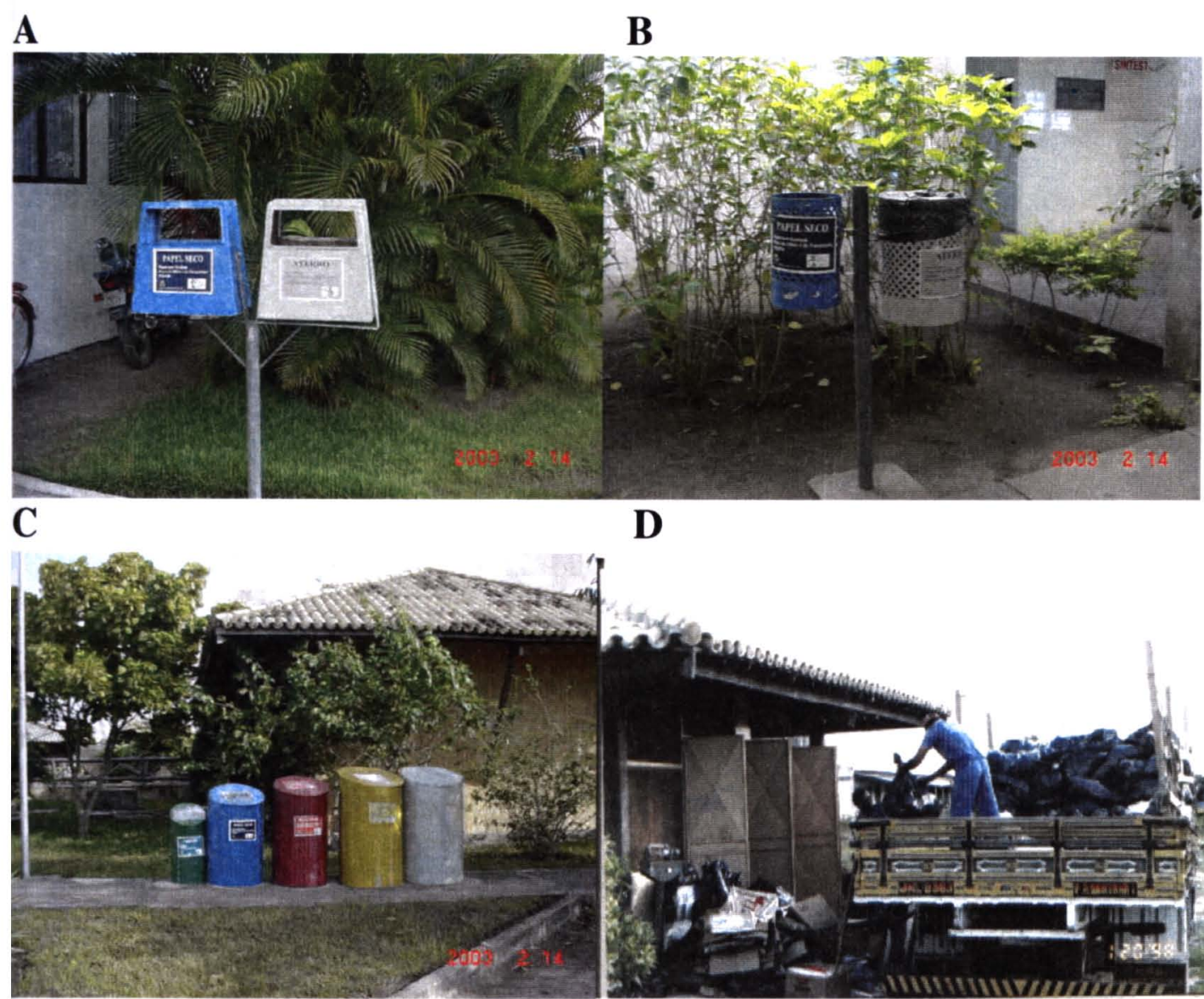

D

$\mathbf{E}$

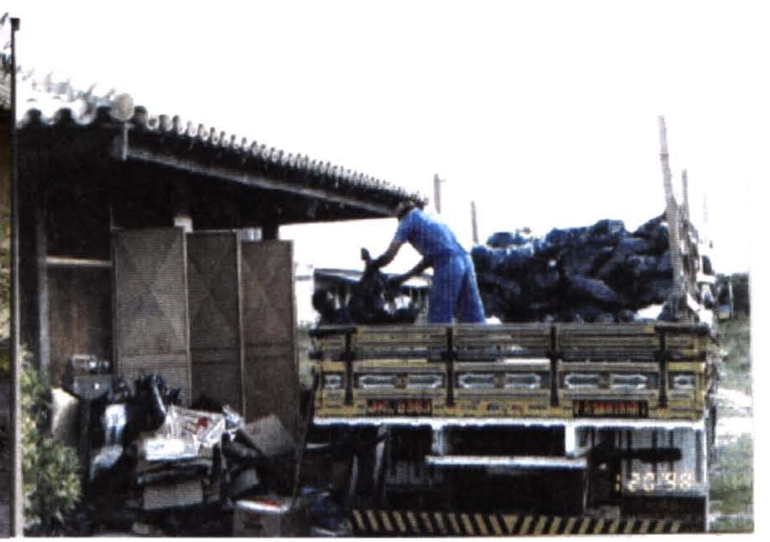

$\mathbf{F}$

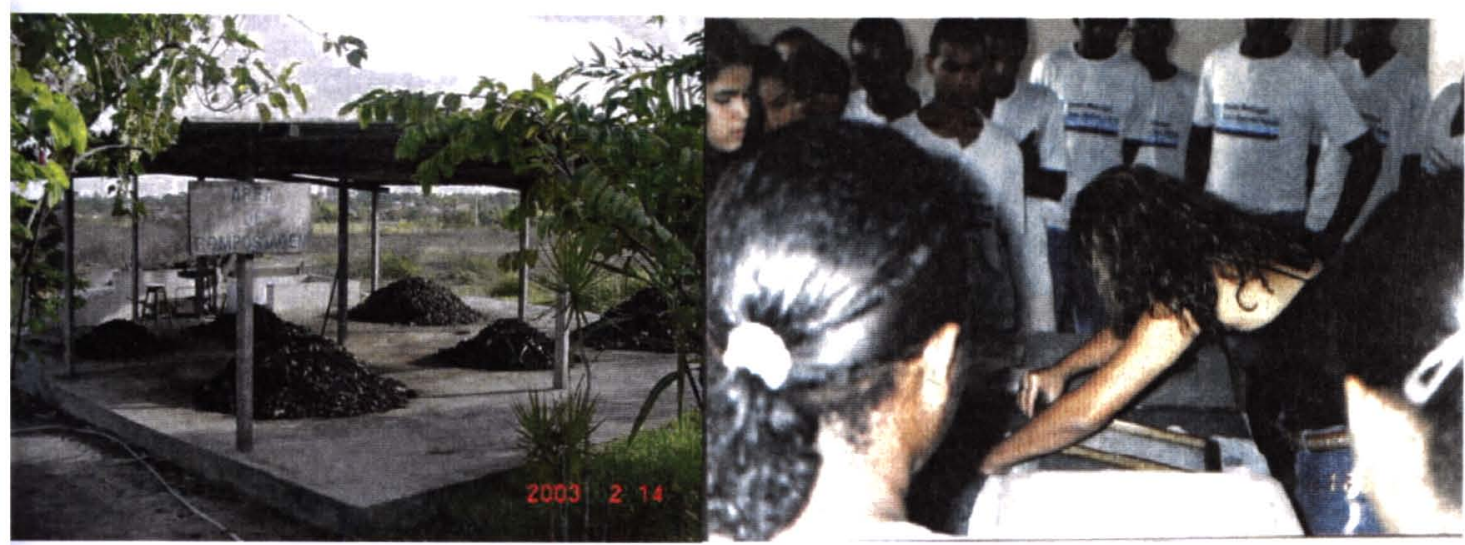

Figura 5 - Acondicionadores para segregar o resíduo papel e o aterro (A e B). Antigos acondicionadores de maior porte para segregação do papel, vidro, metal, plástico e aterro instalados nas cantinas (C). Baias de armazenamento do papel (D). Pátio de compostagem (E). Oficina de papel (F). 
Esta forma de gerenciamento do lixo perdurou até outubro de 1999. Já em anos anteriores, observa-se que havia problemas nessa forma de manejo, sendo apontados como causas principais:

- O crescimento da área construída no campus, que se estendia horizontalmente, da ordem de $56 \%$, como também aumento da comunidade universitária, pela criação de três novos cursos de graduação e implantação de 28 cursos de pósgraduação. Esses dois aspectos traziam como conseqüência maior produção de lixo nos módulos, bem como aumento da distância a ser percorrida pelos funcionários que o coletavam. No início do projeto, a Universidade abrigava suas atividades em seis módulos, biblioteca e parque esportivo. Inicialmente o campus da Universidade era composto pelos seguintes prédios: Módulos administrativos (MA), teóricos (MT) e práticos (MP), em número de seis; Biblioteca; Parque esportivo, Prédio da Manutenção, Casa do Sertão, Cantinas, Residência Universitária, Antigo Prédio da Equipe de Educação Ambiental.

- O incremento do serviço de almoço oferecido pelas cantinas, com maior fluxo de pessoas no local, teve como conseqüência o aumento da geração de resíduos sólidos.

- A policaçamba usada como recipiente para o armazenamento do lixo aterro era deslocada, à medida que as construções avançavam, ficando cada vez mais longe dos pontos de geração dos resíduos. Isto causava o aumento do tempo de deslocamento do funcionário responsável, uma vez que o carrinho de coleta utilizado não comportava todo o resíduo gerado, havendo necessidade de passar mais de uma vez pelos acondicionadores de lixo aterro. A utilização de um carro de coleta maior não era viável devido à dificuldade de seu deslocamento e ao risco de danos à saúde do trabalhador encarregado dessa tarefa.

- O descarte das latas de refrigerante realizado de forma incorreta, isto é, no acondicionador de lixo aterro, fez aparecer, na Universidade, a figura do catador de latinhas no local de armazenamento desse resíduo, o qual rasgava os sacos e espalhava o lixo pelo chão.

- A grande geração de papel em pontos localizados, como no Centro de Convivência e o Centro Administrativo Universitário, e o seu acondicionamento 
em tonéis insuficientes para armazenar a produção diária, além de proporcionar um aspecto desagradável, mostrava que esse tipo de coletor era inadequado para esses locais.

A coleta seletiva foi reformulada para que pudesse ser realizada de forma satisfatória, dotando-se a Universidade com nova infra-estrutura para o projeto, sendo adquirido acondicionadores de maior porte para o papel, e construído um espaço definitivo para o armazenamento do lixo aterro, passando a utilizar-se um trator para o transporte dos resíduos sólidos.

Atualmente, o papel continua a ser coletado, manualmente, somente das lixeiras espalhadas pelos módulos, sendo em sua totalidade depositado em acondicionadores de maior porte para, em seguida, ser transportado pelo trator até a sua respectiva baia de armazenamento de onde será comercializado (Figura 6A e 5B). O resíduo orgânico é retirado das cantinas por um funcionário e colocado em acondicionadores de cor marrom, estacionados em local de fácil acesso ao trator que, em horário pré-fixado, faz a coleta e o transporte até o local da sede da Equipe de Educação Ambiental (EEA) para ser compostado. Da mesma forma, o lixo aterro, depositado nos seus respectivos acondicionadores, é transportado até a baia de armazenamento construída para esse fim, a qual é de fácil acesso para o caminhão coletor do serviço de limpeza urbana do município de Feira de Santana (Figura 7). Neste local de armazenamento do lixo aterro, também foram construídos dois espaços fechados e específicos para receber, respectivamente, o lixo infectante proveniente das clínicas odontológicas, do biotério, dos laboratórios de biologia e as lâmpadas fluorescentes. Como, atualmente, a Prefeitura Municipal de Feira de Santana oferece o serviço de coleta diferenciada do resíduo infectante, este resíduo passou a ser armazenado em lixeiras adequadas, na área externa, próximo à fonte geradora, ficando a espera da referida coleta diferenciada (Figura 6D). As lâmpadas fluorescentes ficam armazenadas para serem encaminhadas, posteriormente, a um reciclador.

Para o acondicionamento do papel do Centro Administrativo Universitário (CAU), Pré-escola, Educação Física e Biblioteca foram previstos acondicionadores de maior porte (Figura 6C). Este lixo passou a ser coletado pelo trator e encaminhado à sede da EEA/UEFS para armazenamento, futura reciclagem e comercialização. 
A

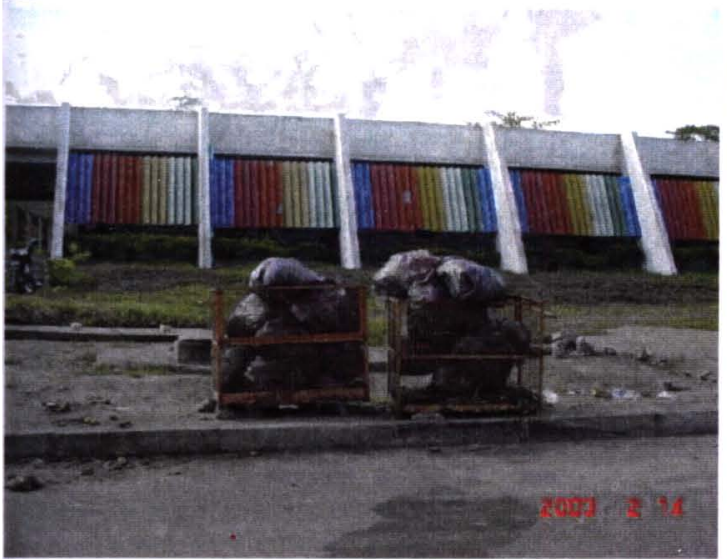

C

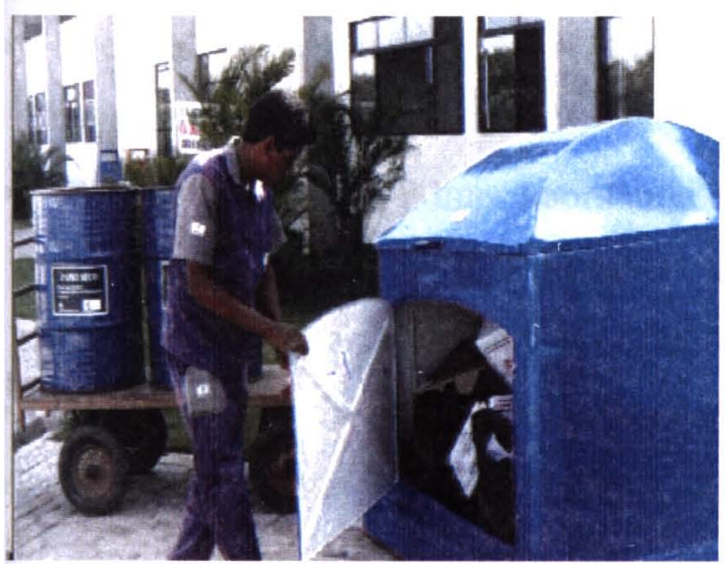

B

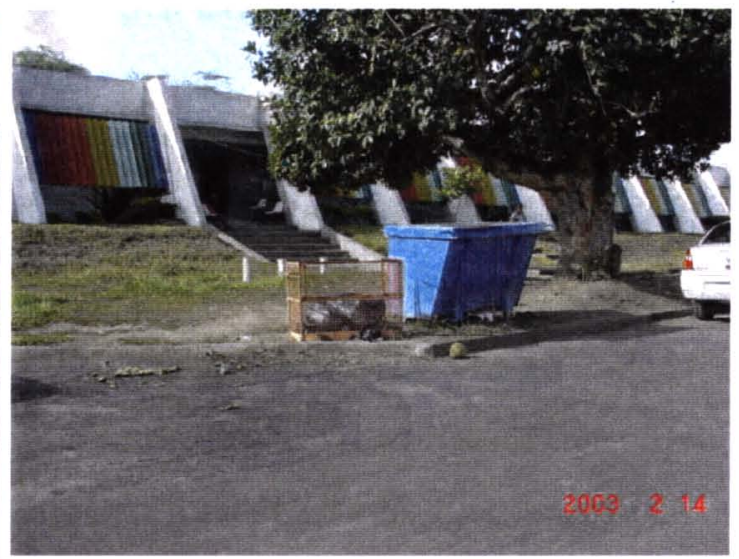

D

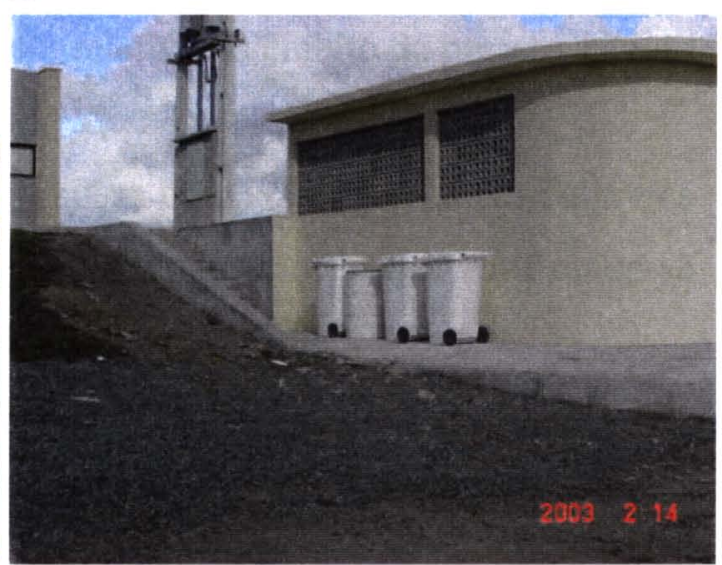

Figura 6 - Acondicionadores de maior porte para armazenamento dos resíduos segregados: (A). Acondicionador de lixo aterro, (B) Acondicionador para o lixo aterro e papel, (C) Acondicionador para papel instalado próximos ao CAU, (D) Acondicionadores para resíduos de serviços de saúde.

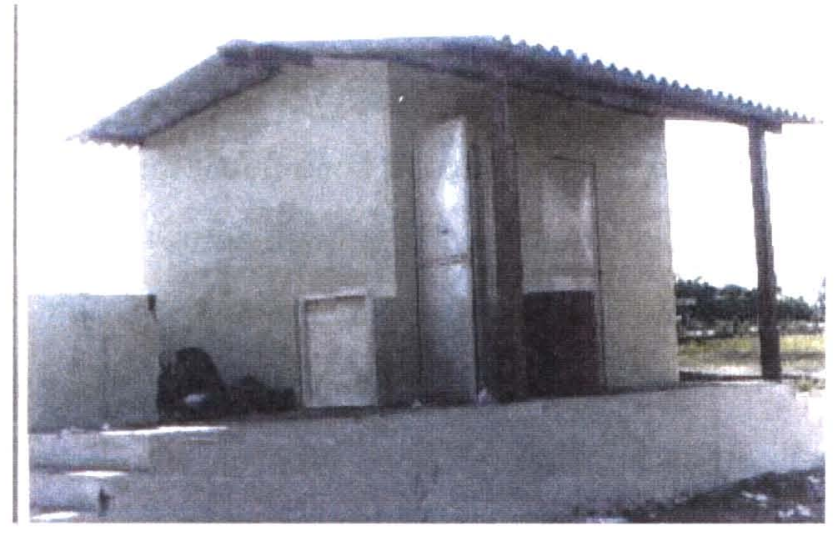

Figura 7 - Local de armazenamento do lixo aterro para posterior coleta da Prefeitura Municipal de Feira de Santana. 


\subsubsection{Educação Ambiental no Projeto Coleta Seletiva e Reaproveitamento do Lixo Gerado no Campus}

As justificativas do projeto Coleta Seletiva e Reaproveitamento do Lixo gerado no Campus estabelecem que "a proposta básica desse projeto é utilizar a Educação Ambiental como elemento de transformação, levando a comunidade universitária (funcionários, estudantes, professores) a uma mudança de comportamento/atitude em relação à problemática do lixo". Para tanto, as campanhas de informação e de sensibilização envolveram:

- Palestras enfocando a importância da coleta seletiva no âmbito da preservação do meio ambiente.

- Mostras de Vídeos e Filmes abordando a limpeza urbana, a diferenciação entre os tipos de resíduos sólidos, o manuseio e reaproveitamento do lixo, utilizando-se exemplos nacionais e as produções realizadas pela EEA/UEFS.

- Cartazes com frases sobre a temática do projeto.

- Adesivos afixados nos acondicionadores, indicando o tipo de lixo a ser depositado em cada recipiente.

Além dessas ações descritas no projeto, são realizadas, esporadicamente, visitas da equipe do projeto às salas de aula para divulgação da coleta seletiva, exposição das peça produzidas nas oficinas de reciclagem, realização de oficinas de papel em locais com grande fluxo de pessoas e palestras semestrais para os alunos ingressantes nos cursos de graduação da UEFS.

"A partir do funcionamento havia todo um esforço em ver o projeto funcionar, identificando quais eram os problemas. Um dos percebidos inicialmente foi o descarte, quer dizer, a participação do aluno neste projeto. Por um bom tempo, eu me lembro que nós ficávamos atentas para vários aspectos do projeto mas, sem dívida, o maior e o mais preocupante era a parte da colaboração, da participação do aluno. Começamos a ver que precisávamos de mais pessoal, de mais estagiários para ajudar, sobretudo, nesta parte da geração, ou seja, do descarte correto do lixo para que, então, todas as etapas subseqüentes funcionassem. Eu acho que foi um momento muito interessante porque, durante os anos seguintes, os bolsistas, os estudantes que trabalharam conosco se envolveram muito e deram uma colaboração 
enriquecedora nesta parte da Educação Ambiental. Foi uma fase muito boa, pela doação destes bolsistas. Claro que recebiam pró-labore mensal, mas a gente via-se que não era isto apenas que os motivava, pois os alunos se envolveram $e$ acreditaram na idéia. Então houve demonstrações de teatro, de artes plásticas, pelo envolvimento destes alunos. Alguns deles saíram, seguiram outras áreas de atuação, mas outros permaneceram e se tornaram profissionais mais envolvidos, mais conscientes da questão ambiental, a partir desta experiência junto à Educação Ambiental e junto ao projeto de coleta seletiva" (Professora integrante da EEA/UEFS).

\subsubsection{Atividades e materiais de sensibilização e informação sobre a coleta seletiva}

\subsubsection{Cartazes}

Foram resgatadas dos relatórios de atividades anuais da EEA/UEFS e das fotos que compõem o acervo da Equipe algumas frases escritas em cartazes e outdoor utilizadas nas campanhas de sensibilização. Estas frases, na sua maioria, foram criadas pelos estagiários do projeto. Os estagiários foram ou são alunos dos cursos de Ciências Biológicas, Engenharia Civil, Enfermagem, Letras, Geografia, História, Administração de Empresas e Odontologia.

Abaixo estão listadas algumas frases utilizadas nas campanhas de sensibilização, separadas em blocos de acordo com seu conteúdo normativo/participativo e reflexivo. Consideram-se como conteúdo normativo/participativo os textos que enfatizavam as normas de segregação dos resíduos sólidos e chamadas para a comunidade universitária participar na coleta seletiva. Os textos considerados reflexivos apresentam conteúdos sobre as conseqüências ambientais do lixo no ambiente, e as possibilidades de seu reaproveitamento. 


\section{Bloco 1 - Conteúdo normativo/participativo}

Muitos cartazes mostram a simbologia das cores das lixeiras com o respectivo tipo de lixo a ser descartado e outros chamam a atenção em relação às cores, como por exemplo:

- "Faça a coisa certa. Coleta Seletiva, a melhor forma de descartar o lixo."

- "Papel é no azul. Coleta Seletiva já".

- "Lixo plástico, lixeira vermelha. Questão de memória."

- “Aterro é o lixo não reciclável. Informe-se. Participe!

- "Coleta Seletiva UEFS. Uma realidade. Participe! Descarte no acondicionador laranja copo descartáveis, canudos, guardanapos. Acondicionador vermelho garrafas plásticas. Acondicionador azul papel seco."

- "Atenção visitantes: Aqui na UEFS nós fazemos coleta seletiva. Observe nas cores das lixeiras distribuídas no campus. Cada cor corresponde a um tipo de lixo, por exemplo:

Papel deve ser jogado na lixeira de cor azul;

Copos descartáveis e papéis engordurados devem ser jogados na lixeira cor abóbora.

- "Não deixe para depois o que você pode fazer agora. SE-PA-RE o lixo: Colabore com a coleta seletiva da UEFS."

- "Projeto Coleta Seletiva. Como Organizar e Levar Esta Tarefa Adiante. Colabore com a separação do lixo".

- "Participo da separação do lixo na UEFS".

- "Na UEFS tem Coleta Seletiva. SE-PA-RE o lixo."

- "O que vale a pena ser feito vale a pena ser bem feito. Se-pa-re o lixo".

- "Estamos fazendo a coleta seletiva do lixo. Participe!"

- "Coleta seletiva. Quem vê lembra (figuras com as lixeiras com cores diferentes). Quem faz aprende".

- "Evite esta cena (figuras mostrando o lixo com diversos insetos). Faça a coleta seletiva."

- “A UEFS adota a coleta seletiva. Você tem consciência disso?" 


\section{Bloco 2 - Conteúdo reflexivo}

- "Reciclar o lixo é preservar o meio ambiente".

- "Se o lixo hospitalar não tem destino adequado, o meio ambiente adoece".

- "Não deixe que o lixo tome conta de seu ambiente" (frase colocada acima de um monte de lixo)

- "Nada se perde, tudo se transforma" (a frase foi ilustrada com fotos do processo de compostagem na UEFS e também um saquinho contendo o composto pronto)

- "Você sabia que as garrafas PET estão sendo recicladas para produzir calças Jeans?"

- "Você mora neste Planeta? Então está na hora de fazer alguma coisa por ele. Em casa, na Universidade, no trabalho, em qualquer lugar. Por exemplo:

Plantar árvores, evitar o desperdício, colaborar com a coleta seletiva. São pequenas atitudes como estas, que fazem de você um verdadeiro ecologista. É só arregaçar as mangas e começar, o resultado vai ser um ambiente melhor para todos.

- "Veja o que acontece com o papel seco jogado na lixeira azul: A EEA RECICLA." (fotos do processo de reciclagem de papel realizado pela EEA).

- "Conscientize-se ... Este não é o melhor destino que você pode dar ao seu lixo. Pense nisso!" (Frase ilustrada com imagem de pessoas e animais em um lixão).

- "Veja o que acontece com os restos de comida jogados no tonel marrom." (Fotos mostrando o processo de compostagem EEA/UEFS).

- "Reciclar é transformar suas próprias atitudes".

- "Me chamam de lixo só por acharem que não sirvo mais pra nada, engano total! Posso ser transformado, só depende de você. SE-PA-RE-ME eu não sou lixo. Ao lado poderá entender que na verdade eu sou um luxo." (Frase ilustrada com materiais reciclados e reaproveitados).

A sensibilização dirigida à comunidade universitária tem como foco principal levar o gerador de resíduos a separá-lo na fonte, para atender ao gerenciamento proposto. Caso isto não ocorra, o lixo que poderia ser inserido novamente na cadeia produtiva, irá para o aterro. Sendo assim, o conteúdo dos cartazes deve abordar os aspectos normativos e ter chamadas para o gerador de resíduos, inserir-se como parte 
fundamental no processo de gerenciamento. Observa-se que a maioria das mensagens presentes nos cartazes tem esse conteúdo normativo e chamadas para que a comunidade universitária participe da segregação. Contudo considerando que a Educação Ambiental não deve apenas resolver a problemática do lixo através da ação individual observa-se que as ações educacionais realizadas poderiam ter ido mais além, utilizando-se nestes cartazes conteúdos que refletissem as causas da existência dos resíduos sólidos, como também suas conseqüências para a saúde e o ambiente e sobre a relação sociedade-natureza, histórica e socialmente construída.

Ainda em' relação ao caráter normativo da maioria dos cartazes, VIEZZER (1996 p.15) observa que essa abordagem pode "dificultar o estabelecimento da relação empática, tão necessária ao aprendizado". Alguns protestos sobre este caráter normativo foram observados nas respostas de alguns alunos nos questionários realizados em 1998 quando comentaram que a "coleta seletiva não deve ser imposta" ou "parece ser lavagem cerebral".

Nos textos incluídos como reflexivos, observam-se conteúdos soltos não relacionando causa efeito como em "Reciclar o lixo é preservar o meio ambiente" ou "Se o lixo hospitalar não tem destino adequado, o meio ambiente adoece". TRAJBER e MANZOCHI, analisando diversos materiais impressos ditos de Educação Ambiental, cita que "poucos textos de Educação Ambiental seguem estruturalmente um modelo de organização textual visto como "ideal": contextualização histórica e social do discurso; abordagem dos efeitos provocados por decisões e atitudes; reflexão que leve a uma consciência do problema; e apresentação de propostas e soluções" (TRAJBER e MANZOCHI, 1996 p.32). Em conteúdos onde aparece a resolução do problema através da compostagem $\mathrm{e}$ reciclagem do papel, o cartaz torna-se mais rico, pois demonstra, à comunidade, que o resíduo descartado corretamente é valorizado, transformando-se em composto e papel reciclado, não sendo encaminhado portanto ao aterro.

Outra observação importante é o pouco incentivo dado a minimização dos resíduos no conteúdo dos cartazes, o que pode levar a sociedade a incorporar valores no sentido de que a reciclagem é a solução, excluindo dela a responsabilidade no enfrentamento da problemática do lixo. Os resíduos, antes de ser encaminhados para reutilização ou reciclagem, devem ter sua geração reduzida ao máximo, sendo essa 
uma ação preventiva dos riscos que representam e dos danos sanitários, econômicos, sociais e ambientais que poderão acarretar devido à sua disposição inadequada ou mesmo na redução do custo de seu gerenciamento e da não degradação de áreas que sua colocação no solo representa. Estes aspectos são os princípios básicos do capítulo 21 da Agenda 21, na qual o manejo dos resíduos sólidos deve ir além do simples depósito ou aproveitamento, mas resolver a causa fundamental do problema através da redução dos resíduos ao mínimo, o que passa pela mudança dos padrões de produção e consumo.

\subsubsection{Adesivos explicativos}

No início do projeto, foram criados adesivos para serem colocados nas lixeiras para identificação do tipo de lixo a ser descartado em cada recipiente específico. $\mathrm{O}$ adesivo utilizava a imagem de um mandacaru (planta semelhante ao cactos comum no semi-árido) estilizado portando uma placa que listava os diversos tipos de resíduo que a respectiva lixeira deveria receber. Em questionários aplicados à comunidade universitária houve reclamações quanto ao tamanho reduzido das letras que compunham as palavras, fato que motivou a não participação daquela no descarte correto dos resíduos nas respectivas lixeiras. Em 1996, esses adesivos foram substituídos por outros com letras maiores e o problema deixou de ser citado nas consultas realizadas à comunidade universitária, posteriormente.

\subsubsection{Recepção dos alunos ingressantes nos cursos de graduação}

A Universidade recebe, semestralmente novos alunos provenientes de diversas regiões da Bahia e de outros estados brasileiros. Como na maioria das cidades brasileiras a forma de manejo do lixo é a coleta e disposição em lixões, os alunos não têm o hábito da coleta seletiva sendo fundamental que eles sejam informados sobre a forma de gerenciamento do lixo da UEFS. Até o ano de 1996, eram utilizados cartazes, exposição de materiais reciclados, distribuição de materiais informativos, palestras em sala de aula. A partir do ano de 1997, além dessas atividades, são realizadas palestras durante o curso de capacitação dado aos calouros 
para a utilização da Biblioteca da UEFS. O curso é promovido pela Biblioteca como pré-requisito para obtenção da senha de acesso ao material bibliográfico e, portanto, cobre um número significativo de alunos ingressantes.

O projeto original determinava que "deverá haver avaliações periódicas das diferentes etapas do projeto", contudo não foi explicitada a forma pela qual essas avaliações deveriam ser realizadas. Em geral, as avaliações constam de aplicação de questionário e caracterização do lixo, como um todo, e do lixo aterro, especificamente. A caracterização é um procedimento que permite quantificar e qualificar os resíduos gerados, sendo portanto, um indicador de resultado da coleta seletiva e da produção do lixo.

\subsubsection{Indicadores de geração de resíduos sólidos na UEFS}

O acompanhamento da geração de lixo na Universidade é realizado através da pesagem diária de cada tipo de resíduo sólido reciclável coletado (papel, vidro, metal, plástico e orgânico) e de pesagens diárias, durante uma semana de cada mês, do lixo denominado "lixo aterro". O valor médio do peso obtido durante esta semana é considerado como a produção diária do mês, para o lixo aterro. Nos meses em que não é possível realizar a pesagem é considerado o valor da geração per capita encontrado no mesmo mês do ano anterior.

A tabela 3 mostra a evolução da geração de resíduo sólido na UEFS, durante o período de 1994 a 2001, bem como a caracterização dos resíduos sólidos realizada em janeiro de 1992, antes da implantação do projeto. 


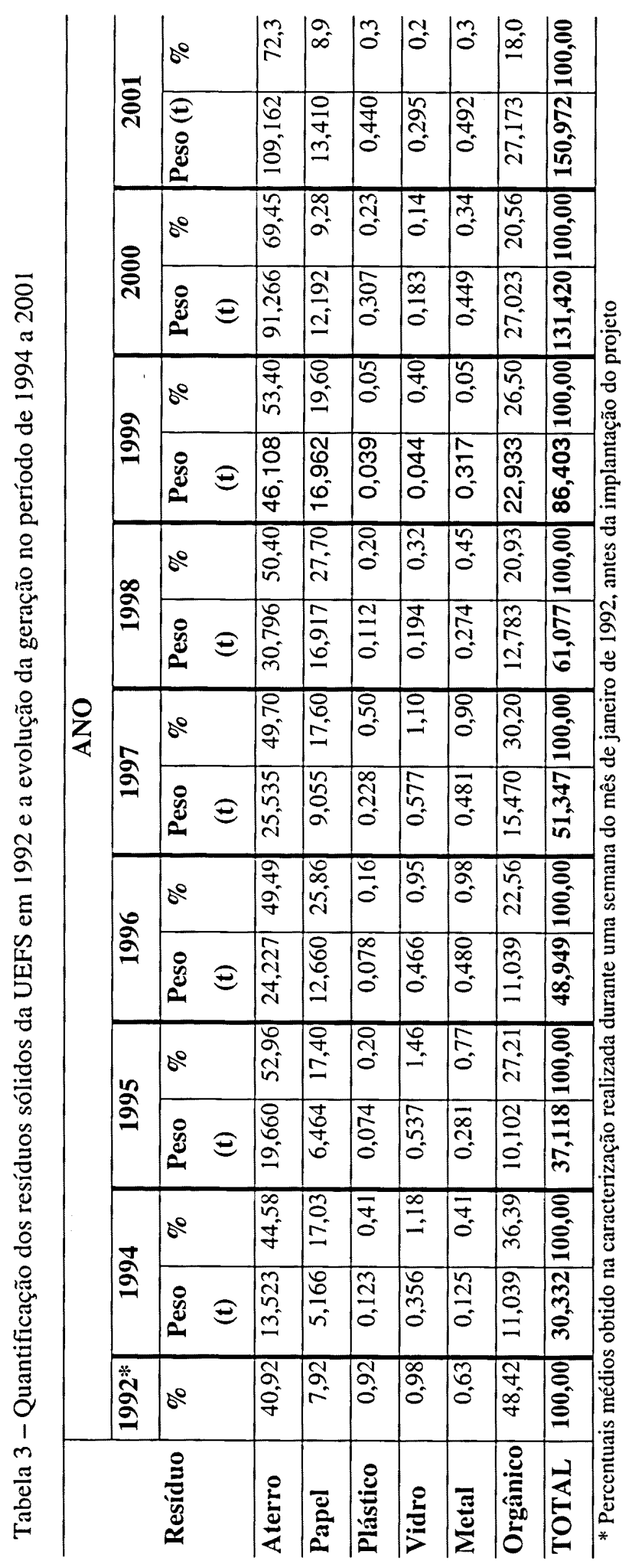


A tabela 4 resume os indicadores de geração anual de resíduos sólidos produzidos na UEFS no período de 1994 a 2001.

Tabela 4 - Evolução dos indicadores de geração dos resíduos sólidos na UEFS, de 1994 a 2001.

\begin{tabular}{|c|c|c|c|c|c|c|c|c|}
\hline \multirow[t]{2}{*}{ Indicador } & \multicolumn{8}{|c|}{ ANO } \\
\hline & 1994 & 1995 & 1996 & 1997 & 1998 & 1999 & 2000 & 2001 \\
\hline Geração total anual $(\mathrm{kg})$ & 30.333 & 37.217 & 48.950 & 51.348 & 61.077 & 86.403 & 131.420 & 150.972 \\
\hline $\begin{array}{l}\text { Geração total anual de } \\
\text { recicláveis }(\mathrm{kg})\end{array}$ & 16.809 & 17.457 & 24.723 & 25.812 & 30.281 & 40.295 & 40.154 & 41.810 \\
\hline $\begin{array}{l}\text { Geração total anual de } \\
\text { recicláveis (\%) }\end{array}$ & 55,42 & 47,04 & 50,51 & 50,30 & 49,60 & 46,60 & 30,55 & 27,30 \\
\hline
\end{tabular}

Considerando-se a geração total anual de resíduos sólidos e os dados sobre o número de pessoas que compõem a comunidade universitária (alunos de graduação + professores + funcionários) foi calculada a geração per capita média anual durante os anos de 1994 a 2001, valores apresentados na tabela 5. A tabela 6 mostra o acréscimo da geração de lixo da UEFS e do valor do per capita médio anual durante o período estudado.

Tabela 5 - Evolução per capita médio anual da geração de lixo na UEFS.

\begin{tabular}{l|c|c|c|c|c|c|c|c}
\hline \multirow{2}{*}{ Indicador } & \multicolumn{7}{c}{ ANO } \\
\cline { 2 - 9 } & $\mathbf{1 9 9 4}$ & $\mathbf{1 9 9 5}$ & $\mathbf{1 9 9 6}$ & $\mathbf{1 9 9 7}$ & $\mathbf{1 9 9 8}$ & $\mathbf{1 9 9 9}$ & $\mathbf{2 0 0 0}$ & $\mathbf{2 0 0 1}$ \\
\hline Comunidade universitária* & 4.930 & 5120 & 5.362 & 5.820 & 6.039 & 6.655 & 7.048 & 7.506 \\
\hline Per capita (kg/pes.ano) & 6,15 & 7,27 & 9,13 & 8,82 & 10,11 & 12,98 & 18,65 & 20,1 \\
\hline
\end{tabular}

Tabela 6 - Acréscimo anual da geração de lixo na UEFS e do valor do per capita médio anual durante os anos de 1994 a 2001.

\begin{tabular}{c|c|c|c|c|c|c|c|c}
\hline \multirow{2}{*}{ Indicador } & \multicolumn{7}{|c}{ ANO } \\
\cline { 2 - 9 } & $\mathbf{1 9 9 4}$ & $\mathbf{1 9 9 5}$ & $\mathbf{1 9 9 6}$ & $\mathbf{1 9 9 7}$ & $\mathbf{1 9 9 8}$ & $\mathbf{1 9 9 9}$ & $\mathbf{2 0 0 0}$ & $\mathbf{2 0 0 1}$ \\
\hline $\begin{array}{c}\text { Acréscimo na geração } \\
\text { anual (\%) }\end{array}$ & - & 18,5 & 24,0 & 4,7 & 15,9 & 29,3 & 34,2 & 12,9 \\
\hline $\begin{array}{c}\text { Acréscimo no valor do } \\
\text { per capita (\%) }\end{array}$ & - & 15,4 & 20,4 & $-3,4$ & 12,8 & $\mathbf{2 2 , 1}$ & 30,4 & 7,2 \\
\hline
\end{tabular}


Observando-se os dados relacionados na tabela 6, verifica-se que a geração anual de lixo na Universidade teve um acréscimo que variou de 4,7 a 34,2\% ao ano, com um valor médio de $19,9 \%$. Outro dado que chama a atenção é o valor do incremento do per capita anual que variou de $7,2 \%$ a $30,4 \%$, com exceção do ano de 1997, quando houve um decréscimo de 3,4\%. A média do incremento anual do per capita de lixo foi de $15,5 \%$. Esse fato é um fenômeno que ocorre em vários lugares do mundo, a exemplo da cidade de Porto Alegre, cuja produção de lixo vem crescendo 5\% ao ano, e da cidade de Curitiba onde, para coletar o lixo em 1995, foram utilizados 40 caminhões e, em 1997, esse número aumentou para 51 (CEMPRE, 1997 citado por GRIMBERG E BLAUTH 1998 p.52). Contudo, deve-se ter cautela ao afirmar-se que o aumento da geração do lixo seja apenas reflexo do consumo. Esse crescimento pode ter sido em função da melhoria da eficiência da coleta, como também, devido a uma maior cobertura do serviço dentro do município, conseqüentemente um maior volume de resíduos sólidos coletados.

Na publicação A União Européia e a Gestão de Resíduos afirma-se que um dos temas de grande preocupação do cidadão europeu é o aumento alarmante da produção de resíduos: "nos últimos seis anos, o volume de resíduos sólidos aumentou 10\% ao ano" (Comissão Européia, 2000). Para deter esse avanço na produção de residuos, os países pertencentes à Comunidade Européia têm utilizado várias estratégias, tanto educacionais como técnicas, econômicas e legais. Por exemplo, limitar a geração per capita anual de resíduos sólidos em cerca de $300 \mathrm{~kg} /$ pessoa/ano, introdução de tecnologias apropriadas, políticas ambientais orientadas ao produto, taxação sobre a geração de resíduos e programas de redução de resíduos nas escolas (Öko-Institut e.V,1999).

A falta de incentivo à minimização de resíduos na UEFS, a instalação de sua gráfica, o crescimento do número de seus cursos e a conseqüente instalação de novos equipamentos, como também a informatização aí ocorrida nos últimos anos, influenciaram o incremento da geração de resíduos. "A produção de resíduos é consequiência do nosso modo de vida insustentável. O nosso modelo atual de produção e consumo deve ser adaptado, a fim de minimizar as pressões exercidas sobre os recursos da Terra. Em resumo, a produção de resíduos é um dos melhores 
indicadores do nosso progresso e do desenvolvimento insustentável" (Comissão Européia, 2000).

Outro dado que merece atenção especial é o decréscimo da quantidade de resíduos recicláveis coletados nos últimos três anos. Isto pode ser reflexo da redução das atividades educacionais e da divulgação, previstas no projeto. A conseqüência disso é o descarte incorreto do lixo pela comunidade, o qual deixa de ser reaproveitado.

“... o que tem que melhorar realmente são as campanhas de Educação Ambiental. Têm que ser retomadas, têm que ser mais fortes, a gente tem que ser mais atuante junto à comunidade universitária para que elas possam assim, envolver melhor, porque é justamente essa carência, a falta de envolvimento da comunidade universitária com o projeto que fica a desejar. Eu acho que o principal problema é este. Acho que a gente deveria promover, estou falando da EEA, palestras, oficinas, ir junto à comunidade universitária e trabalhar com ela, mostrar as nossas próprias dificuldades em termos de destinação do lixo aqui na Universidade para que todos se conscientizem de que o envolvimento deles é importante para o sucesso do projeto" (Estagiário da EEA).

Fatores que também podem ter influenciado na diminuição da quantidade de resíduos recicláveis coletados e, conseqüentemente no aumento do lixo aterro:

- Erros na pesagem e, até mesmo, a não pesagem dos resíduos recicláveis por parte do funcionário da coleta. Observou-se que, nos últimos anos, o peso aferido pelo comprador do papel da UEFS foi maior que o registrado nas planilhas de pesagem desse resíduo;

- Ineficiência da coleta do resíduo por parte do funcionário responsável. Já foi constatado pela Equipe que a substituição desse funcionário reflete positivamente na quantidade dos recicláveis coletados;

- Utilização, pelas cantinas, de polpa de frutas industrializadas para o preparo dos sucos comercializados em detrimento das frutas, conseqüentemente, diminuindo a parcela de resíduo orgânico coletado;

- Resíduos resultantes da poda realizada na UEFS deixaram de ser computados na caracterização por dificuldades operacionais. 


\section{Caracterização do lixo aterro}

O lixo aterro, definido pelo projeto, é aquele composto por resíduos não recicláveis e/ou sem mercado na região de Feira de Santana. A caracterização do lixo aterro tem por objetivo quantificar o resíduo reciclável presente nesta massa. Quanto menor a quantidade de reciclável encontrado, maior é a eficiência da coleta seletiva e, conseqüentemente, da participação da comunidade universitária no projeto.

Até o ano de 1997, a metodologia de caracterização do resíduo aterro consistia em seis amostras, uma por módulo. Cada amostra de lixo coletado era transportada até a sede da EEA e despejada em uma lona sendo triado separadamente o metal, o plástico, o vidro, o papel, o orgânico e o aterro. $O$ resultado permitia aos técnicos EEA observar em que setor da UEFS a coleta seletiva não estava sendo realizada de forma satisfatória, necessitando portanto de campanhas de sensibilização. No ano de 2000 , foi realizada apenas uma caracterização do lixo aterro e a amostra foi obtida tomando-se, aleatoriamente, os sacos contendo o lixo aterro após ter sido coletado pelo trator, até atingir o peso de $100 \mathrm{~kg}$. Durante os anos de 1998 e 1999 não foi realizada esta atividade. A tabela 7 mostra os resultados dessa caracterização, considerando a média anual do percentual de resíduos recicláveis encontrados no lixo aterro.

Tabela 7 - Percentual médio de lixo reciclável encontrado no lixo Aterro gerado na UEFS, em 1994 a 1997 e 2000.

\begin{tabular}{c|c}
\hline Ano & $\begin{array}{c}\text { Lixo reciclável encontrado no lixo aterro } \\
(\%)\end{array}$ \\
\hline 1994 & 27,12 \\
\hline 1995 & 17,67 \\
\hline 1996 & 18,71 \\
\hline 1997 & 20,09 \\
\hline 2000 & 69,60 \\
\hline
\end{tabular}

Pela tabela acima, observa-se que as médias anuais de lixo reciclável no aterro variaram de $17,67 \%$ a $20,09 \%$ quando foi considerado a média de recicláveis obtido de amostras coletada por módulo, anos de 1995 a 1997. Nas amostras pontuais, como as dos anos de 1994 e 2000 , os valores forma mais elevados, sendo que, nas deste último, excessivamente elevados, mesmo com uma queda considerável 
dos recicláveis coletados (Tabela 4). A freqüente caracterização do lixo aterro informaria à Equipe sobre a participação da comunidade universitária na coleta seletiva, levando a EEA a interferir imediatamente no processo através de campanhas de sensibilização e de treinamento de funcionários de limpeza e de coleta.

\subsubsection{Considerações sobre os questionários aplicados à comunidade universitária, nos anos de 1996, 1998 e 1999.}

Outra forma de avaliação do projeto foi através da aplicação de questionários a comunidade universitária (professores, funcionários e alunos). Foram realizados questionários durante os anos de 1996, 1998 e 1999 com este objetivo. Estes questionários não mantiveram a mesma metodologia ao longo dos anos, variando a amostra e o conteúdo das perguntas. No entanto, seus resultados não foram analisados, nem divulgados pela EEA.

Pela análise dos questionários aplicados nos anos citados acima, ressaltam-se:

- O conhecimento dos alunos sobre o projeto coleta seletiva diminuiu consideravelmente de 1996 para 1999, refletindo na quantidade de lixo reciclável coletado na UEFS, conforme já observado anteriormente nos indicadores de geração dos resíduos sólidos, tabela 4.

- Os alunos que têm menor conhecimento sobre o projeto são os matriculados nos cursos de Odontologia e os dos curso noturnos de Economia e Direito.

- Os alunos que acham válida a coleta seletiva argumentam que, com essa forma, o meio ambiente é preservado, evita-se o desperdício e educa-se o cidadão Também consideram que a coleta seletiva é importante para manter a limpeza, criando normas educacionais no campus.

- Os argumentos dos alunos que não acham válida a coleta seletiva foram: "A coleta seletiva é dispensável, não é bem divulgada, sendo uma forma de prender a atenção das pessoas com o supérfluo, condicionando o seu comportamento, é uma lavagem cerebral". "Não é válida porque ninguém colabora". 
- Os entrevistados tomaram conhecimento da coleta seletiva na UEFS, em ordem de citações: cartazes, exposição de materiais reaproveitados/reciclados, folder e por último através de palestras.

- A grande maioria dos alunos entrevistados tem uma ótima ou boa impressão sobre a limpeza da UEFS.

- Segundo os alunos entrevistados, a melhor maneira de divulgar um projeto de coleta seletiva é através, em ordem de citação: da TV, do rádio, do jornal; de panfletos/folhetos/folder/adesivos; de cartazes; de visitas em sala de aula/reunião com estudantes; de palestras/minicursos.

- Sobre o conteúdo a ser abordado nos diversos meios de divulgação, foram citadas: as vantagens do processo, experiências bem sucedidas de coleta seletiva, importância e benefícios da coleta seletiva para o meio ambiente e para a saúde.

Os resultados obtidos nos questionários confirmam os encontrados por NUNESMAIA (1997) em questionário aplicado durante o ano de 1994, quando foi observado que o maior desconhecimento sobre o projeto está entre os alunos dos cursos noturnos. Os cartazes também foram os instrumentos informativos mais citados pelos alunos em todas as pesquisas. 


\subsubsection{O Discurso do Sujeito Coletivo}

\section{Característica dos professores entrevistados}

Os professores entrevistados optaram pela carreira de docente universitário devido ao ambiente que lhes é proporcionado: "a forma como o conhecimento brota aqui, a forma como as informações são vistas e veiculadas, a oportunidade que você tem de contatar com o conhecimento, com o saber, com esse processo evolutivo que é o de produzir saber, enfim, é um espaço onde se discutem idéias. As relações de trabalho não são tão rígidas sobre certos aspectos, embora piores com relação a outros. É interessante, pode-se fazer coisas de que se gosta". Sobre as oportunidades existentes na UEFS, por ser ela uma Universidade jovem : "as condições de trabalho aqui são muitas boas. Quando eu a comparo com a minha Universidade de origem, e com a última que fiz pós-graduação, acho que a UEFS nos oferece uma boa estrutura, bem como, boas relações de trabalho, tanto com os colegas, como com os alunos. Eu acho que, apesar de algumas restrições, abre espaços para se crescer e inovar. Guardadas as devidas proporções, ela possibilita a realização de um trabalho mais interessante do que o realizado em outras instituições que eu conheço. A gente se apaixona pela Universidade e não quer mais sair".

\section{Característica dos alunos entrevistados}

Os alunos entrevistados escolheram a UEFS porque, além de ser o local em que foram aprovados no vestibular, é uma Universidade pública; por estar localizada próximo a sua cidade de origem, ou na cidade em que moram; e porque a consideram uma Universidade de qualidade dentro das estaduais. Um aluno citou que escolheu a UEFS porque se identificou muito com o projeto do curso escolhido. 


\section{Característica dos funcionários entrevistados}

Dos funcionários entrevistados, um trabalha na UEFS desde sua implantação: "quando eu estudava na faculdade, surgiu um movimento de implantação da Universidade, então eu, como aluna e moradora de Feira de Santana, resolvi ajudar em sua implantação. Eu passei lá três anos estudando, durante os quais participei ativamente do processo de implantação da Universidade. Depois que eu me formei, fui convidada pelo diretor da faculdade para trabalhar e quando a Universidade foi inaugurada, em 1976, eu fui contratada como sua funcionária".

Um dos entrevistados, depois de ter estudado na UEFS, voltou como funcionário: "Eu fui estudante e, nesse período, comecei a gostar mais da Universidade, comecei a lutar por ela e querer que ela desse certo, como deu. E a partir daí, eu saí como profissional, trabalhei durante quatro anos fora e, no primeiro concurso que apareceu na Universidade, fiz, passei e fiquei porque gosto de trabalhar aqui”. Outros justificaram estarem trabalhando na UEFS porque é um órgão público e, também, porque existe a possibilidade de continuar seus estudos: "hoje o que todo mundo quer, na realidade, é trabalhar num órgão público, porque é melhor do que você trabalhar numa empresa privada, e porque a Universidade só tem a acrescentar à gente. Permitiu-me trabalhar e estudar". 


\subsubsection{O Discurso do Sujeito Coletivo sobre o Projeto}

Foi perguntado aos professores, alunos e funcionários: "Gostaria que você falasse sobre o Projeto de Educação Ambiental que é desenvolvido aqui na UEFS. $O$ que você sabe sobre ele"? As idéias centrais expressas nas falas dos entrevistados estão relacionadas no quadro 5. Em seguida, são expressos os discursos do sujeito coletivo (DSC) referente a cada idéia central. No anexo 1 , são relacionadas às expressões-chave referentes a cada idéia central expressa pelos diferentes sujeitos

Quadro 5 - Idéias Centrais expressas pelos professores, alunos e funcionários da UEFS referente ao seu conhecimento sobre o projeto.

\begin{tabular}{|c|c|}
\hline Sujeito & Idéia Central \\
\hline Professor & $\begin{array}{l}\text { 1. Projeto relacionado ao lixo; } \\
\text { 2. É um trabalho interdisciplinar e atua nas três missões da } \\
\text { Universidade (Ensino, Pesquisa e Extensão); } \\
\text { 3. No início tinha divulgação. }\end{array}$ \\
\hline $\begin{array}{l}\text { Aluno } \\
\text { (A) }\end{array}$ & $\begin{array}{l}\text { 1. Projeto relacionado ao lixo; } \\
\text { 2. Trabalha também com extensão; } \\
\text { 3. No início tinha divulgação. }\end{array}$ \\
\hline $\begin{array}{c}\text { Funcionário } \\
\text { (F) }\end{array}$ & $\begin{array}{l}\text { 1. Projeto relacionado ao lixo; } \\
\text { 2. Ele dá visibilidade à UEFS. }\end{array}$ \\
\hline
\end{tabular}

\section{Idéia Central: Projeto relacionado ao lixo.}

\section{DSC P}

Bom, eu tenho que confessar, inicialmente, que não conheço muita coisa sobre esse projeto ${ }^{P 3}$. Se me lembro, tem dez anos, começou em $1992^{P 2, P 3}$. Nesse ano, eu comecei a ouvir falar sobre a Equipe de Educação Ambiental da UEFS, criando essa equipe. Eu cheguei a participar de algum seminário, de alguma atividade relativa a isso, eu cheguei a ler alguma coisa a respeito da proposta da equipe, mas não tenho conhecimento muito maior a respeito disso ${ }^{P 3}$. É um projeto que procura a participação da comunidade universitária, procurando conscientizá-la sobre 
tratamento do lixo, como removê-lo adequadamente do campus da Universidade ${ }^{P 1}$. Sei que uma das coisas básicas do projeto é a coleta seletiva, a questão do lixo ${ }^{\text {P3 }}$. Acho que fica a olhos vistos que existe algum trabalho neste sentido, apesar de não perceber a comunidade tão consciente desse trabalho. Sei do núcleo e do trabalho que se desenvolve $\left.\right|^{P 4}{ }^{P 4}$ da reciclagem de material, ${ }^{P 3, P 4, P 5}$, tanto papel, como adubos, com a compostagem que eu sei que é feita ${ }^{P 1}$. Sei Também sobre as lixeiras e, através destas medidas, buscam-se formas de resolver o problema, que é um problema contemporâneo mesmo, este da questão do lixo, do lixo urbano sobretudo ${ }^{P 3}$.

As pessoas foram devidamente orientadas, porque eu me lembro, principalmente, da questão de, não só colocar as cestinhas nos módulos, mas de se colocarem determinados tonéis nas cantinas. Houve todo um processo de divulgação, informativo com cartazes. Eu lembro que havia cartazes, as cestinhas eram todas identificadas e cada tipo de lixo deveria ser colocado nas nelas ${ }^{P 5}$. Havia os adesivos e esta parte visual para mim é clara ${ }^{P 4}$. Então, o que eu sei gira em torno disso: de coleta seletiva, de reciclagem através de uma proposta de educação, de uma reeducação das pessoas, das crianças, das pessoas de forma geral, ligadas, ou não, à instituição. Através dessa concepção de educação, de reeducação, tentava-se resolver a questão do lixo e o que fazer com ele, já que, cada vez mais a gente tem mais lixo e precisa ter um destino para este lixo ${ }^{P 3}$.

\section{DSC A}

Sei do programa de educação, da coleta seletiva, dos coletores e dos cartazes. Isso foi o que eu conheci de imediato ${ }^{A 8}$. Sei da Equipe em que o pessoal trabalha, basicamente, com a reciclagem de lixo ${ }^{A 1}$ e da seleção de lixo, tem a postura seletiva do material utilizado aqui na UEFS ${ }^{A 3}$. Ele procura separar os resíduos em metal, vidro e há uma usina de compostagem que recicla matéria orgânica. Acho que é mais isto, eu sei bem da compostagem que realiza, transforma o material orgânico ${ }^{A 5 A 8}$ e das oficinas de reciclagem de papel que é desenvolvida lá ${ }^{A 8}$, se os outros materiais são separados e são utilizados aqui mesmo para outras coisa, não sei. Só sei que são separados, tem uma triagem deste material ${ }^{45}$ tem as cestinhas de lixo que a gente vê $\hat{e}^{2}$, tem as vasilhinhas pintadas de azul, verde $e$ cor abóbora. Só que eu não sei dizer onde coloca cada lixo já que é seletivo, só se eu 
olhar e ler. Só pela cor, não dá para identificar, mas eu acho isso legal, porque não é só a questão da organização, mas a questão da reciclagem. Fica mais fácil, e também serve para manter a UEFS limpa ${ }^{A 3}$.

Ao entrarmos na faculdade, eu fui orientada sobre isto: as latas, a coleta seletiva que tem a compostagem, foi mais ou menos nesta parte para começar o processo daqui da Universidade e depois quem sabe até lá fora ${ }^{A 9}$. Nós tivemos contato com colegas do curso de biologia e eles colocaram para a gente a importância da coleta seletiva, a importância de separar o lixo que nós iríamos jogar fora aqui na Universidade; inclusive, em todos os módulos há uma preocupação, tendo cestas específicas como a cesta de aterro e outra para papel seco, justamente para facilitar essa questão da coleta seletiva que é muito importante e foi abordado por eles ${ }^{A 7}$. A gente, quando entrou na Universidade, como calouro, procurava conhecer mais a Universidade e daí fomos lá para baixo, tem uns lugares lá que reciclam papel, parte da reciclagem de todo o lixo que é jogado aqui na UEFS nestas cestas, aí a gente conheceu esta parte da reciclagem, como é que funciona ${ }^{A 4}$. Só que eu nunca tive muita proximidade assim de ingressar no grupo, procurar saber realmente quais são os fundamentos deles. Mas em questão da organização da coleta seletiva eles trabalham muito bem ${ }^{A 6}$.

\section{DSC F}

Não sei muita coisa ${ }^{F l, F 5}$. O que eu sei do projeto de Educação Ambiental é que foi uma coisa maravilhosa que aconteceu aqui na UEFS porque, antes, o lixo era um absurdo, devido à quantidade de alunos, funcionários, muita gente e cada um com uma educação diferente, cada um com uma maneira. Daí, surgiu este programa de Educação Ambiental, então, foi reciclado o lixo. Não existe mais lixo na Universidade, foi separado, reciclado e o que eu sei é assim... ${ }^{F 4}$ sei que faz reciclagem de papel, quando eu arrumo os arquivos, eu separo os papéis e ligo para eles pegarem. Eu mesmo já recebi cadernos, rascunhos e outros objetos reciclados aqui na UEFS mesmo ${ }^{F l}$. Foi uma coisa maravilhosa e seria ótimo se fosse estendido para Feira e região, através de um órgão ou de um departamento que tivesse esta separação e sob a gerência da EEA, sob a administração da EEA. E quem conheceu a Universidade antes desse projeto de lixo, Ave Maria, hoje está uma maravilha, 
limpíssima ${ }^{F 4}$. É um projeto que vem sendo desenvolvido e vem trazendo grandes benefícios não só para a Universidade como também para a comunidade. Não só para a comunidade de Feira como também da região, da micro região de Feira. Os beneficios são para o meio ambiente, na preservação do meio ambiente ${ }^{F 3}$.

\section{Idéia Central: É um trabalho interdisciplinar e atua nas três missões da Universidade}

\section{DSC P}

Acho que eu sei menos que deveria saber, mas já sei que é um trabalho que existe há muito tempo, é um trabalho que tem para mim hoje, embora tenha demorado entender que era um trabalho interdisciplinar e vejo, como um dos poucos, onde as pessoas estão efetivamente trabalhando. Muitas vezes me serviu de espelho, de exemplo, me serviu de inspiração para fazer pesquisa. Ela não só se restringe a pesquisa mas faz extensão e ao meu ver de forma bem razoável, bem interessante ${ }^{P 2}$. Eu faço visitas com meus alunos e a avaliação que eles fazem é que é um começo, que é bom ${ }^{P l}$. O trabalho de educação, mesmo com relação às escolas, os alunos indo visitar, palestras, o trabalho da população mesmo e trabalhos outros que eu já tive conhecimento que vocês fazem em outras prefeituras, em outras cidades, levando essa parcela de contribuição no sentido da reciclagem do lixo, uma forma racional de trabalhar com essa questão ${ }^{P 4}$. Eu não sei como funciona a interdepartamentalidade na equipe. Eu sei que tem gente de outros departamentos, pois em alguma época participei de algumas coisas, de seminário junto com o pessoal de CHF e vi que vocês também fazem outras coisas, a questão da Educação Ambiental; a gente só conhece a parte da coleta seletiva, certamente porque é mais transparente, mais visível em todos os espaços da Universidade. Mas depois a gente vai descobrindo que tem toda aquela parte de Educação Ambiental mesmo, de reaproveitamento e tem a parte mais de Engenharia. Em termos de concepção eu acho muito interessante pois consegue trabalhar a interdisciplinaridade, multifuncionalidade e atua nas três missões da Universidade que é o ensino pesquisa e extensão. Eu acho isto muito interessante ${ }^{P 2}$.

Eu acho que faltava um pouco... ensino, talvez pela interdisciplinaridade não fica tão transparente para o ensino, embora na parte de pesquisa e extensão passe 
para mim uma imagem muito interessante. Agora com a pós-graduação deve ter dado um salto em termos de envolvimento nos trabalhos da equipe ${ }^{P 2}$.

\section{Idéia Central: Trabalha também com extensão}

\section{DSC A}

Sei que tem trabalho de extensão, que eles fazem visitas as feiras livres para ver a questão da educação desse pessoal que trabalha em feiras livres, da coleta, da destinação dos residuos e que ainda pretendem desenvolver projetos de esgotamento sanitário $^{A 8}$. Também de vez em quando a gente traz alunos da escola pública, eu leciono em escola pública, para a gente ter informações e fazemos algumas oficinas lá no $E E A^{A 1}$. Eu quando ensinei, na Feira e Cultura com meus alunos da $5^{a}$ série o tema foi este, coleta seletiva. A gente fez um trabalho de mostrar a reciclagem, mostramos o adubo que a gente conseguiu aqui da UEFS e fizemos reciclagem de papel, fizemos uma oficina e esclarecemos, fizemos lixeira ${ }^{A 9}$.

Eu estive lá para fazer um trabalho, um artigo sobre resíduos sólidos, eu estive lá na Educação Ambiental e também estive lá porque na minha cidade nós estávamos com problema de disposição de resíduos sólidos e procurei a área de Educação Ambiental, procurei pelos professores ${ }^{A 2}$.

\section{Idéia Central: No início tinha divulgação}

DSC P

A Coleta seletiva, no primeiro momento, me causou uma certa impressão, depois de um tempo parece que deu uma parada no entusiasmo. No primeiro momento, houve mobilização, depois arrefeceu este ânimo. Acho que ficou mais rotineira, o pessoal olhava, achava bonitinho, aquele negócio coloridinho mas não sentia o funcionamento na Universidade ${ }^{P 2}$. Houve uma desativação ou uma despreocupação, não sei, um desgaste, todo um processo de desgaste com relação a isso e não houve uma conservação desse processo informativo ${ }^{P 5}$. Semestralmente então saindo e entrando pessoas aqui que precisariam ser devidamente orientadas, devidamente esclarecidas para poder fazer com que esse processo de coleta seletiva 
pudesse funcionar ${ }^{P 5}$. Deveria ser um trabalho mais transparente, para que efetivamente envolva a comunidade. Tem um grande problema, essa comunidade é cíclica, tem sempre gente nova para orientar. Tem momentos em que o pessoal participa mais, tem momentos em que o pessoal participa menos e acho que depende muito das ações ${ }^{p 2}$ e, eu suponho que hoje não esteja acontecendo isso. Eu suponho, pelo que eu vejo das cestinhas e pela falta de informação e pelo próprio falar, as pessoas não falam mais nisso; é como se passasse despercebida a existência desse processo seletivo $^{P 5}$. De uns tempos para cá, acho que houve um momento que voltou a ficar mais forte, acho que melhorou, mas ainda falta, eu sei que é um trabalho difícil, um trabalho de conscientização é árduo, trabalho de mudança de cultura, mudança de hábito ${ }^{P 2}$.

Eu não sei o que acontece posteriormente a essa coleta seletiva. Eu acho que vi alguma coisa no restaurante, sobre como o material é reciclado lá embaixo e foi a única informação que eu tive. Soube também que no EEA eles reciclam papel e que eles vendem envelopes reciclados, eu estive inclusive há pouco tempo lá no EEA $e$ achei interessante a proposta, mas há pouca divulgação com relação ao trabalho desenvolvido lá. Primeiro pela localização ${ }^{P 5}$, a questão de isolamento, a localização no espaço geográfico da Universidade ${ }^{P 2}$ ela é praticamente desmembrada dos módulos $^{P 5}$, e acaba não tornando mais transparente todas as ações da equipe ${ }^{P 2}$. Então ir até lá é uma prática que acho que poucas pessoas têm. Na realidade, eu estive lá por acaso. Eu achei interessante a proposta desenvolvida pelo EEA. Eu acredito que a maior parte das pessoas que fazem parte da Universidade, que convivem em nosso ambiente universitário não tem conhecimento disso ${ }^{P 5}$.

\section{DSC A}

Eu acho um projeto muito legal, logo no inicio eu acompanhei este projeto, acho que tinha mais informação, ele aparecia mais. Hoje em dia, os calouros não têm informação sobre ele, as pessoas não sabem exatamente onde jogar, o que significam as cores. Apesar de estar escrito ali grandão, as pessoas fazem muita confusão. Chega e não fica sabendo o que é isto, para onde vai, o que se faz com o lixo, antes eu acompanhei boa parte do projeto, a compostagem ${ }^{\text {Al }}$. Nós sabemos que tem, quando eu entrei na Universidade houve maior divulgação. As pessoas saíam 
de sala em sala de aula, distribuíam adesivos, mas depois disto não vejo mais divulgação dentro da Universidade mesmo. Em termos de informação, eu acho meio deficitário ${ }^{A 2}$.

Foi por acaso que conheci esse projeto ${ }^{A 4}$ em visita ao prédio dessa equipe de Educação Ambiental; visitamos as oficinas de reciclagem de papel ${ }^{48}$ mas não que alguém explicasse que existe o projeto, como é feito, não ${ }^{A 4}$, além das cestas que tem escrito ali o que deve ser colocado. De lá para cá, eu não vi tanta divulgação em termos de coleta, acho que continua a mesma coisa, no mesmo ritmo, as pessoas que iam entrando, é o que eu suponho, recebiam esse tipo de esclarecimento, junto ao treinamento da biblioteca, que existia esse projeto e essa divulgação ${ }^{A 8}$.

Eu acho o projeto muito desvinculado da Universidade, como se fosse um órgão à parte, não sei se é a questão de distância, mas as pessoas não têm o costume de freqüientar a área ambiental ${ }^{\mathrm{A} 2}$.

\section{Idéia central: Ele dá visibilidade a UEFS}

\section{DSC F}

Desde o início, eu já ouvia falar desse projeto. Foi um projeto que foi bastante divulgado e a gente começou a ouvir falar dele. A gente ouve falar na Universidade e fora dela e, inclusive, a Universidade tem assim um destaque nesse trabalho, ele faz com que a Universidade seja conhecida também. A gente ouve em todos os lugares referência ao trabalho da Equipe de Educação Ambiental ${ }^{F 2}$. 


\subsubsection{O Discurso do Sujeito Coletivo sobre as mudanças no campus em função do projeto}

Para obter a representação sobre a percepção dos entrevistados sobre possíveis mudanças no campus, em função do projeto, foi aplicada a seguinte pergunta: "Na sua opinião, o projeto mudou alguma coisa na UEFS? Fale sobre isto". As idéias centrais obtidas dessa questão estão relacionadas no quadro 6.

Quadro 6 - Idéias Centrais expressas pelos professores, alunos e funcionários da UEFS referente a percepção sobre mudanças no campus em função do projeto.

\begin{tabular}{|c|l|}
\hline Sujeito & \multicolumn{1}{|c|}{ Idéia Central } \\
\hline $\begin{array}{c}\text { Professor } \\
(\mathbf{P})\end{array}$ & $\begin{array}{l}\text { 1. } \text { Mudou, principalmente na questão do lixo; } \\
\text { 2. Mudou só no início. }\end{array}$ \\
\hline $\begin{array}{c}\text { Aluno } \\
(\mathbf{A})\end{array}$ & $\begin{array}{l}\text { 1. } \text { Mudou, principalmente na questão do lixo; } \\
\text { 2. Eu não acredito que tenha mudado tanto. }\end{array}$ \\
\hline $\begin{array}{c}\text { Funcionário } \\
\text { (F) }\end{array}$ & 1. Mudou, principalmente na questão do lixo. \\
\hline
\end{tabular}

Idéia central: Mudou, principalmente na questão do lixo.

DSC P

Mudou, quando a gente vê os coletores de lixo já chama a atenção. A gente procura jogar no local certo, não deixando contaminar o ambiente. Quando a gente vai fazer, automaticamente se lembra de que existem lixeiras em cada módulo. A gente mudou o comportamento em relação a dar um destino final ao lixo, mudou o comportamento de alguns, precisa mudar mais ainda, mas já há uma mudança. A gente vê uma conscientização melhor dos alunos ${ }^{P 1}$. Embora eu não conhecia antes, com relação aos meus alunos, em todas as turmas eu tive, pelo menos um, aluno que se interessava pelo trabalho do ambiente e esteve envolvido com o núcleo de vocês, eles estão antenados com esse trabalho ${ }^{P 4}$. Então eu acho que mudou. A gente não fica sempre satisfeita com as coisas e acha que deveria mudar mais. Vejo que as pessoas têm outra postura na ocupação deste espaço público e a relação das pessoas 
com o espaço público que é a Universidade, é diferente da relação das pessoas em outro espaço público na cidade, como em Feira de Santana e mesmo em outros lugares. Eu acho que, se não tivesse o trabalho, as pessoas não se comportariam bem no sentido de ter esta preocupação, pois, mesmo com esta dificuldade de utilizar e participarem da coleta, para mim está muito claro: se não houvesse o programa, se fosse uma coisa nomal, como já vi em outras universidades, as pessoas, pelo menos, olham, têm uma certa preocupação em não descartar o lixo de forma aleatória de qualquer jeito. Acho que o trabalho tem levado as pessoas a se acostumarem com o colorido das lixeiras e acho que seria uma coisa muito estranha se não houvesse. As pessoas têm procurado colocar nas cestinhas. Eu pelo menos tenho olhado e vejo que está bom ${ }^{P 2}$.

\section{DSC A}

Mudou, mudou principalmente a questão do lixo. Antes do projeto, o lixo era espalhado, era queimado, e, inclusive, o esgoto também na parte do fundo aparecia, e o lixo ficava aí muito espalhado. Depois, com o projeto, houve um trabalho com os funcionários e mesmo nos próprios departamentos há uma seleção e a gente está vendo que tem um resultado ${ }^{A l}$. Desde que eu entrei aqui, foi o ano que começou a implantar esse projeto, ou já tinha implantado eu não sei, mas estava no começo ainda e essa questão do lixo era muito incômodo. A gente usava muitos baldes de lixo, era com o lanche misturado com vasos plásticos, ficava um horror, sem contar com tanta mosca, principalmente nas cantinas. Selecionaram vasos com tampões para lixo orgânico e esses vasos mais abertos que são diferenciados por cores para colocar vidros, papel seco e copos descartáveis. Então mudou bastante a questão da higiene $^{A 6}$ e também nesta questão de organização e de limpeza ${ }^{A 2}$.

Acho que mudou, sim, não para todo mundo mas para algumas pessoas criaram uma consciência maior ${ }^{A 5}$, principalmente na conscientização tanto do corpo discente, como do corpo docente e também dos demais funcionários dentro da instituição. A gente vê que o comportamento da maioria é de auxiliar, de prestar realmente solidariedade à natureza aqui e isso vem acontecendo ${ }^{A 7}$. Eu acho que, para algumas pessoas, provocou alguma mudança ${ }^{A 5}$. 
Então eu acho que o que ele tem de positivo é que acaba alertando as pessoas. No processo de coleta seletiva, primeiro podemos observar que ele alerta as pessoas por um lado, mas por outro lado não há o envolvimento das pessoas com o projeto. Então, mesmo tendo as cestas e mesmo todo mundo sabendo o que colocar em cada cesta, $\mathrm{eu}$, pelo menos, procuro fazer isto sempre que eu passo. Mas a gente observa, de maneira geral, e até pelo fato de vocês terem colocado aquele out-door, é que as pessoas não colaboram muito com o próprio projeto ${ }^{A 2}$

\section{DSC F}

Mudou pelo menos na seleção de lixo ${ }^{F 2}$, no aproveitamento de lixo para a reciclagem e que volta para dentro da UEFS, para a gente ter o material reciclado ${ }^{F 4}$. Isso melhorou bastante o ambiente da Universidade ${ }^{F 2}$. Antes, não tinha essa organização toda no caso do lixo, dos materiais que hoje são reciclados e no caso aqueles que não eram ${ }^{F l}$. As pessoas ficam mais conscientes na separação de lixo, embora seja pouco, deve amadurecer muita gente aqui dentro ${ }^{F 4}$. A Universidade era muita suja. Há 8 anos atrás, quem conheceu a Universidade não reconhece devido à limpeza e também à reforma que ela sofreu. Mas em relação a limpeza, você não vê lixo, até as folhas no jardim eles pegam para fazer o adubo orgânico $^{F 5}$ e tem economia de papel. As pessoas, antes, jogavam tudo fora e agora tem aproveitamento, não tem tanto desperdício ${ }^{F 4}$. Os papéis começaram a ser reciclados e aí vem trazendo beneficio para a Universidade, porque os papéis são reaproveitáveis e aí se faz outras coisa com esse papel, como papel machê e papel para a escolinha e para a creche ${ }^{F 2}$. Eu acho que tem sido válido este projeto ${ }^{F 2}$, só acrescenta nos trabalhos, no desenvolvimento e do jeito que o governo está incentivando a reciclagem e tudo eu acho que a Universidade tem que continuar ${ }^{F I}$.

A gente observa, claramente, o comportamento das pessoas que estão no dia a dia da Universidade, em relação à limpeza, à coleta de lixo. A gente percebe a diferença quando recebe um público novo, de outras comunidades, pessoas que participam de atividade durante um dia na UEFS e, até mesmo, da comunidade feirense, que naquele dia a limpeza da Universidade é diferente, as pessoas não têm aquele mesmo comportamento de deixar o lixo no lugar certo e é claramente 
perceptível quando tem um número grande de pessoas que não são da comunidade universitária ${ }^{F 3}$.

\section{Idéia central: Mudou só no início}

\section{DSC P}

Olha, para mim ele mudou quando foi implantado, no caso da coleta seletiva de lixo. Porque, realmente, as pessoas tinham uma preocupação em onde colocar o lixo. Hoje, pelo processo de desgaste, pela não preocupação em manter ativo esse processo, eu acredito que essas mudanças sejam incipientes. Eu, mesmo, ao saber que existia uma cestinha de uma cor e uma cestinha de outra cor e numa cestinha de uma cor colocava isso, na de outra cor, aquilo mas já tem tanto tempo que eu li essas informações que eu não as memorizei e aí, na dúvida, vai na que está mais próximo. Inclusive, a gente tem um resto de papel que poderia e deveria ser reciclado e a gente já entrou em contato varias vezes para virem buscar esse papel e até hoje o papel está aí. Então, hoje eu não acredito que tenha realmente uma mudança, que a gente possa perceber, detectar essa mudança ${ }^{P 5}$.

\section{Idéia central: Eu não acredito que tenha mudado tanto}

\section{DSC A}

Eu não acredito que tenha mudado tanto, mudaram as instalações do local, mas o projeto, eu não acompanhei essa mudança, essa evolução. Eu acho que continua, não sei se estava num patamar satisfatório já naquela época e aí se acomodou. Eu não sei se fazem também acompanhamento dessa entrada e saída de estudante, dessa demanda do campus. Eu vejo, ainda, um pouco desorganizadas as cantinas, a destinação dos papéis, eu não sei se conseguem separar suficientemente para fazer o trabalho, então eu não posso lhe dar uma resposta com relação a isso, porque eu não acompanho diretamente ${ }^{\text {A8 }}$. A sede é muito afastada da realidade dos alunos. Eu acho que a maioria das pessoas lá fora acha que a EEA só tem coleta seletiva, que a linica coisa que faz é só separar o lixo e muito estudante não sabe o que acontece com o lixo aqui dentro. É uma coisa assim, tem na UEFS coleta Seletiva, mas para quê? Ninguém é instruido para o que vai fazer, benefícios, nada 
disto ${ }^{A 9}$. Não sei até que ponto é feito essa reciclagem realmente. Então, a coisa aqui, na prática, aqui nesta parte dos estudantes jogarem o lixo na cesta não é realizada, mas lá em baixo eles podem até fazer a separação ${ }^{A 4}$. 
4.1.6.3 O Discurso do Sujeito Coletivo sobre as mudanças pessoais ocorridas em função do projeto

Para obter a representação sobre alguma mudança pessoal provocada pelo projeto, a pergunta foi: "Em você, o projeto provocou alguma mudança? O quadro 7 apresenta as idéias centrais observadas nas falas dos sujeitos entrevistados

Quadro 7 - Idéias Centrais expressas pelos professores, alunos e funcionários da UEFS referente a mudanças pessoais em função do projeto.

\begin{tabular}{|c|c|}
\hline Sujeito & Idéia Central \\
\hline $\begin{array}{l}\text { Professor } \\
\text { (P) }\end{array}$ & $\begin{array}{l}\text { 1. Mudou, principalmente em relação ao descarte do lixo; } \\
\text { 2. Eu já tinha preocupação com o lixo; } \\
\text { 3. Mudou só em determinado período. }\end{array}$ \\
\hline $\begin{array}{l}\text { Aluno } \\
\text { (A) }\end{array}$ & $\begin{array}{l}\text { 1. Mudou, de hábitos em relação ao descarte do lixo; } \\
\text { 2. Não mudou, eu já tinha preocupação com a questão ambiental; } \\
\text { 3. Não mudou. }\end{array}$ \\
\hline $\begin{array}{l}\text { Funcionário } \\
\text { (F) }\end{array}$ & $\begin{array}{l}\text { 1. Mudou, principalmente em relação ao descarte do lixo; } \\
\text { 2. Solidificou a consciência ambiental que eu já tinha. }\end{array}$ \\
\hline
\end{tabular}

Idéia Central: Mudou, principalmente em relação ao descarte do lixo

\section{DSC P}

É um projeto para a qual a gente tem que criar uma consciência nova: como a gente vai remover este lixo ${ }^{P I}$. Já existe a questão do hábito, mas o fato de ver aquilo ali já me induz, em outros lugares, a fazer. De certa forma a gente fica ligado pelo fato de ver as lixeirinhas aqui. Eu vou a qualquer lugar e não consigo mais jogar o lixo no chão. Eu não consigo mesmo, se tenho um lixo, ponho-o dentro do bolso da calça e depois descarto. Embora não tenha coleta seletiva, eu chego em algum lugar e descarto. De certa forma, fui influenciado, se não, estaríamos num patamar mais atrasado de jogar o lixo no chão. A mudança de hábito, que é um problema cultural, leva um bom tempo e já fiquei desesperado porque não achava uma lixeira ${ }^{P 2}$. 
Eu acredito que mudou sim, pois quando eu passo isto para os meus alunos, significa que eu já mudei em termos de achar que é um projeto bom. O projeto é uma referência dentro da Universidade, a gente está dando aula, convida alguém do EEA, esta pessoa vem e já traz informações práticas, não fica só na teoria. Eles realizam, realmente, esta prática de remoção adequada do lixo ${ }^{P 1}$. Qualquer trabalho que eu faça, exposição de painel eu uso papel reciclado de lá, e está sempre indicando o trabalho da $E E A^{P 4}$.

Em relação a outras questões ambientais, de certa forma me despertou interesse em saber o que as pessoas fazem, discutir o que fazem, até me aproximei un pouco da discussão de resíduos sólidos urbanos e que acho fundamental que tenha gente pesquisando ${ }^{P 2}$. Você pensar que tem um grupo de pessoas que são preocupadas com a questão do lixo! Acho que isso, em mim, despertou uma satisfação, por saber que tem pessoas que estão preocupadas com o lixo, que estão buscando e trazendo propostas para a solução do problema. Eu acho que o que mais me tocou foi isso, saber que existe isso este projeto ${ }^{P 3}$.

\section{DSC A}

Sim. A gente que está nesta área mais voltada para o meio ambiente acha muito interessante. Eu sempre me interessei pela a área da Educação Ambiental, a gente até tenta fazer em outros locais ${ }^{A 5}$, porque eu sou professora e trabalhei com meus alunos algumas coisas neste sentido; já utilizei, nas minhas turmas e sempre estou tentando fazer isto ${ }^{A 1}$. A gente tentou, sabe que é dificil em escolas de ensino médio é mais difícil, mas já tentei ${ }^{A 5}$. Quando entrei aqui, não conhecia, ou conhecia muito pouco de saneamento, conhecia as coisas básicas, educação doméstica que a gente tem, que é bom mas não tem uma visão global mais abrangente do que venha a ser o saneamento, a importância sanitária ${ }^{A 8}$ Esta consciência também me ajudou na separação do lixo, mas eu sinto falta de que este projeto se espalhe para a cidade. Por exemplo eu separo lata ou papel em casa mas não tem para onde levar. Algum papel eu faço doação, eu já fiz doação para a equipe. Mas a gente não tem para onde levar isto, então deveria expandir mais ${ }^{A l}$.

Eu não sei chegar na rua e jogar papel no chão, eu sempre procuro um local para jogar o papel, mesmo que não seja no local adequado, porque aqui é separado 
por cores, mesmo que não seja assim eu sempre procuro ${ }^{A 3}$. Aqui na UEFS eu estou esquecida que lixeira é, não tenho vergonha, leio, olho todas ${ }^{A 9}$ : é aqui? Não, anda mais um pouquinho e joga o lixo no lugar certo ${ }^{A 5, A 9}$. Então, para mim, é consciência, eu sei que começou aqui e tenho consciência na rua ${ }^{A 9}$. Eu, quando estou na rua, me envergonho de jogar o lixo no chão, fico com vergonha, fico procurando, só jogo em uiltimo caso. Então para mim mudou ${ }^{A 9}$.

O projeto fez pensar, porque eu acho que essa questão da separação do lixo é muito melhor, é muito legal. Eu acho que é uma questão de evitar até uma certa contaminação, a proliferação de mosca, de mosquito que traz maior prejuízo para a gente e de ratos também; é bem interessante ${ }^{A \sigma}$.

\section{DSC F}

O lixo, pelo menos na Universidade, melhorou muito e, se melhora o espaço fisico, melhoram também as pessoas que trabalham aqui ${ }^{F 2}$, então de qualquer forma educa as pessoas e você se sente melhor, em um ambiente limpo você se sente ótima, em ambiente desorganizado até você fica desorientada. A gente jogava uma ponta de cigarro fora, agora não joga mais, um palito de fósforo você já se retrai, você não faz mais isto, devido a quê? Você vê tudo limpinho você não vai sujar ${ }^{F 4}$. A gente tem assim na mente que os lixos devem ser aproveitados, inclusive aqui mesmo a gente separa assim papelão, papéis que não servem mais, essas coisas e até, às vezes, liga para a EEA e manda recolher tudo ${ }^{F l}$. Antes a gente jogava tudo fora e, agora, não, tem um setor ${ }^{F 5}$ e também aqui a gente tem o cuidado de colocar os lixos nas lixeiras adequadas e antes ninguém fazia isso e inclusive, orienta também as pessoas que às vezes jogam copinho plástico misturado com papeis e tudo ${ }^{F 1}$.

Em termos ambientais, eu sei que tem que reciclar, não se deve jogar fora, que prejudica a natureza ${ }^{F 5}$ só que nem todo o mundo tem a mesma concepção para isso. Ás vezes, tem comodismo de chegar numa lixeira correta para jogar o lixo nos lugares devidos ${ }^{F 1}$. 


\section{Idéia Central: Eu já tinha preocupação com o lixo}

\section{DSC P}

Olha, eu já tinha esse hábito, eu já tinha essa preocupação com o lixo. Eu acho que faço isso instintivamente, tecnicamente eu não jogo lixo na rua, eu sou daquelas que guardam o papel na bolsa, o pauzinho de picolé na bolsa e educo minha filha desta forma. Então em mim não teve mudança ${ }^{P 3}$.

\section{DSC A}

Essa preocupação com a questão ambiental é uma coisa que eu trago comigo há bastante tempo, e pela disciplina na área ambiental na nossa grade curricular, a gente já teve a nossa mentalidade bastante aguçada. Também essa preocupação da instituição com a questão ambiental veio contribuir para a gente realmente ter essa consciência contínua, não uma coisa que possa se perder com o tempo, mas solidificá-la ${ }^{A 7}$.

\section{DSC F}

O projeto só veio fortalecer aquilo que eu penso sobre o meio ambiente a importância que tem de a gente preservar o meio ambiente. Desde muito tempo, a gente no dia a dia, pensa que o meio ambiente é muito importante e que a gente tem que cuidar dele. Então, o projeto só veio solidificar essa consciência que eu já vinha adquirindo na minha experiência, ao longo da minha vida ${ }^{F 3}$.

\section{Idéia Central:Mudou só em determinado período}

\section{DSC P}

No período inicial, sim. Hoje eu ainda guardo resquícios, porque eu sei que existia a cestinha para cada coisa. Mas eu não lembro qual é a cestinha em que vai o quê, ou eu acho que estou colocando na cestinha certa. As cestinhas que sobraram aí e algumas foram removidas, desapareceram, poucas ficaram disso daí. Bom eu pessoalmente sinto falta disso. Em Montreal, eles têm uma coleta seletiva na cidade, então existe o dia de lixo orgânico e o dia de lixo seco e então, você, convivendo com aquilo, acaba se acostumando. É igual ao cinto de segurança, que a gente não 
usava, e você é obrigado a usar e quando você se acostuma com aquilo, com o uso do cinto você faz automaticamente. Então, aqui, eu acho que existem dificuldades. As dificuldades de se desenvolverem esses hábitos das pessoas fazerem sem pensar. E para que isso acontecesse, realmente, todo semestre, os alunos que chegam deveriam ser orientados. Antes nos MPs e nos MTs existiam as cestinhas entre os módulos e essas cestinhas não existem mais. Existem cestas de lixo só que não são seletivas. Tudo bem, as cestas estão lá, mas não são seletivas. Então, mudou em determinado período, a questão do meu comportamento. Hoje, eu tenho cuidado de não jogar lixo ónde não deve ser jogado, mas em selecionar o lixo, eu não posso mais assegurar que houve uma mudança, eu perdi isso ${ }^{P 5}$.

\section{Idéia Central: Não mudou}

\section{DSC A}

Não mudou. Quando eu entrei na Universidade, achei interessante, quando conheci, achei interessante. Achei interessante, também, o fato da Universidade ser arborizada, trabalhar nesta questão. Eles colocam animais silvestres, tem miquinhos, várias árvores, andam soltos, tem criatório de serpentes, tem biotério, tem vários animais, achei interessante. Para mim, pessoalmente, está meio distante, só se tiver mais próximo de cursos como biologia ou outros cursos que eles podem trabalhar ou não mais essa questão. ${ }^{A 4}$. Ele não influencia muito a vida da gente lá fora, é como se o projeto fosse da Universidade e não da comunidade, da sociedade. Essa percepção não vem só do projeto de Educação Ambiental, como dos projetos gerais da Universidade. Então, é uma característica geral da academia, da Universidade em relação à sociedade, não há integração ${ }^{A 2}$. 


\section{Análise dos discursos obtidos das questões 1, 2 e 3}

Vários aspectos podem ser retirados do discurso coletivo resultante da aplicação das entrevistas no ambiente universitário. Com relação à descrição do projeto e às mudanças provocadas com sua implementação no campus e nas próprias atitudes pessoais, destacam-se:

- A comunidade universitária tem conhecimento do programa de Educação Ambiental da UEFS e estabelece uma correlação forte do projeto com a coleta seletiva.

- Os acondicionadores de lixo coloridos e os adesivos explicativos chamaram a atenção e tiveram um impacto inicial importante, contudo, ao longo do tempo, mesmo reconhecidos como parte da paisagem do ambiente da Universidade, perderam o interesse da comunidade e, conseqüentemente, a função. Contudo, a segregação dos resíduos sólidos produzidos na fonte geradora não se tornou rotineira. SAWAIA (2001) chama a atenção para o fato de que as estratégias utilizadas para motivar a participação são homogeneizadoras e centradas em uma única necessidade ou questão social; tal processo, embora necessário para romper com o cotidiano alienador, deve ser utilizado com cuidado para não prolongá-lo, gerando o empobrecimento da percepção e das necessidades. Isso também é reforçado pela idéia central obtida de que o projeto "só mudou no início", sentimento expresso tanto por professores com mais de dez anos na UEFS, quanto por alunos com vivência menor que cinco anos.

- Os cartazes e, principalmente, o colorido das lixeiras são citados como a forma de conhecimento imediato sobre o projeto.

- A preocupação com a entrada de novos alunos a cada semestre é explicitada salientando-se a importância das informações sobre o projeto aos ingressantes. Contudo, observa-se que alguns professores, com muito tempo na UEFS, "perderam", ou não têm a prática da segregação dos resíduos na fonte. Conforme MOSER (2001, p.201), os efeitos induzidos nos sujeitos, no que se refere aos comportamentos pró-ambientais, têm, além da adaptação sob a forma de adoção transitória de um novo comportamento, uma forte tendência a voltar aos hábitos 
comportamentais anteriores. A exposição às pressões produz um desequilíbrio, induzindo à tendência de se reintegrarem comportamentos iniciais.

- Depreende-se, das falas, que há pouco envolvimento e "colaboração" com o projeto, dando a impressão de que a coleta seletiva não the diz respeito. SORRENTINO (1998) chama atenção sobre isto ao descrever sobre a quinta dimensão da participação, que é a subjetividade. Não há participação, sem que as pessoas se sintam envolvidas com aquela situação; as pessoas devem se sentir pertencentes ao local e sentir que tudo a sua volta lhe diz respeito.

- A importância atribuída, pelos participantes, à divulgação do destino dado aos resíduos sólidos após a coleta seletiva, e o retorno da informação sobre os resultados quantitativos: quantidade coletada de cada tipo de resíduo reciclável; montante dos recursos auferidos com a comercialização dos resíduos ou dos produtos reciclados; tipos de operações/transformações sofridas pelos resíduos, que resultam em diferentes produtos; entre outros. Esses resultados quantificáveis produzem os indicadores de desempenho do projeto, os quis devem ser levantados, comparados periodicamente e divulgados à comunidade, no sentido de, além de produzirem conhecimento e de servirem para a avaliação do trabalho, figurem como elementos de motivação para a continuidade das ações, um estímulo visível para que o mesmo não pare.

- A pouca visibilidade das ações desenvolvidas pela Equipe de Educação Ambiental e a localização da sede dessa equipe, a qual é isolada dos prédios onde se realizam as atividades administrativas e de ensino. No espaço dessa sede são desenvolvidas as principais atividades relacionadas à recuperação dos resíduos sólidos coletados: o armazenamento dos recicláveis, a fabricação de produtos de papel reciclado (embalagens, cartões, cestas...) por meio da oficina de papel, a compostagem dos resíduos orgânicos e as atividades promotoras da EA, no sentido da informação, divulgação e capacitação do público interno da Universidade e de visitantes externos. Essa unidade conta com acervo bibliográfico sobre questões ambientais - algumas publicações resultaram da ação da Equipe de Educação Ambiental - e com exposição permanente dos produtos ali produzidos, sendo inclusive comercializados. No entanto, essas ações não são conhecidas pela comunidade universitária como um todo. O conhecimento desse 
local e do trabalho aí desenvolvido, para algumas pessoas da comunidade universitária, resulta do acaso de oportunidade não socializada, não sendo, portanto, associadas ao projeto e ao seu alcance.

- O projeto influenciou na mudança de hábitos em relação ao descarte do lixo (não jogar o lixo no chão) e serviu para reforçar a consciência ambiental que algumas pessoas já possuíam, antes de entrar em contato com o mesmo.

- Especificamente em relação à não colocação do lixo na lixeira apropriada, afirma-se que há esquecimento, ao longo do tempo, da associação do tipo de material e a cor apropriada da lixeira, e que muitas destas foram removidas. Em observações realizadas no campus, constata-se que as lixeiras continuam espalhadas em todos os locais e todas são identificadas com os adesivos explicativos. Portanto, a infra-estrutura para se participar da segregação na fonte é oferecida. Resta apenas jogar o lixo no lugar certo, conforme concebido pelo projeto, ação que deve ser espontânea e sem caráter punitivo. Conforme DEMO (1998), “muitas desculpas são justificação do comodismo, já que participação supõe compromisso, envolvimento, presença em ações". Muitas vezes, esforço físico, como no caso, ler os adesivos afixados nas lixeiras para a identificação do tipo de lixo a ser descartado.

- A questão ambiental, como problema ligado à área de Biologia, é também apresentada. Isto pode estar relacionado com a prática do ensino formal, a qual limita a internalização das questões associadas ao meio ambiente aos seus aspectos naturais, não inserindo, neste contexto, os aspectos socioculturais.

- O caráter extensionista do projeto foi lembrado, tanto pelos alunos, como pelos professores. O espaço do projeto foi utilizado pelos alunos que já atuam como professores no ensino médio e fundamental como laboratório para suas atividades de classe e como fonte de consulta para trabalhos na área ambiental.

- A atitude dos usuários das cantinas, em relação ao descarte do lixo, e sua desorganização, chama a atenção da comunidade universitária. Esse fato pode ser um indicativo de que o espaço das cantinas deve ser um local estratégico para ações de sensibilização da comunidade e de implementação de práticas de mudança de hábito. 
- Foi observado, nos discursos, que a limpeza da UEFS muda para pior, quando há atividades para pessoas não pertencentes à comunidade universitária.

- A questão dos resíduos sólidos foi percebida como uma problemática, tanto relacionada à área educacional, como à tecnológica. A interdisciplinaridade do projeto chama a atenção pela possibilidade de trabalhos que agreguem professores e alunos dos diversos departamentos da UEFS.

- O curso de especialização em Educação Ambiental para a Sustentabilidade foi citado como forma de fortalecimento do ensino de graduação. 


\subsubsection{O Discurso do Sujeito Coletivo sobre a participação da comunidade universitária no projeto.}

Para saber se havia uma participação e de que forma esta participação se relacionava com o projeto de Educação Ambiental desenvolvido na Universidade, foi perguntado aos professores, funcionários e alunos: "Você participa, de alguma forma, deste projeto? Fale-me sobre isto". No quadro 8 estão as idéias centrais obtidas.

Quadro 8 - Idéias Centrais expressas pelos professores, alunos e funcionários da UEFS referentes à sua participação no projeto.

\begin{tabular}{|c|c|}
\hline Sujeito & Idéia Central \\
\hline $\begin{array}{l}\text { Professor } \\
\text { (P) }\end{array}$ & $\begin{array}{l}\text { 1. Participo indiretamente, colocando o lixo no seu devido local; } \\
\text { 2. Não participo por falta de informação. }\end{array}$ \\
\hline $\begin{array}{l}\text { Aluno } \\
\text { (A) }\end{array}$ & $\begin{array}{l}\text { 1. Participo indiretamente, colocando o lixo no seu devido local; } \\
\text { 2. Não participo, só no descarte do lixo. }\end{array}$ \\
\hline $\begin{array}{l}\text { Funcionário } \\
\text { (F) }\end{array}$ & $\begin{array}{l}\text { 1. Participo indiretamente, colocando o lixo no seu devido local; } \\
\text { 2. Participo na separação do lixo e na divulgação do projeto. }\end{array}$ \\
\hline
\end{tabular}

Idéia Central: Participo indiretamente, colocando o lixo no seu devido local.

\section{DSC P}

Minha participação é indireta ${ }^{P 1, P 4}$, não participo ativamente não tenho uma participação prática com a Equipe ${ }^{P 1}$, a não ser no descarte ${ }^{P 2}$. A gente tem o cuidado de ver onde está botando o lixo e o que é que vai botar no lixo, o que é que a gente pode aproveitar, tentar selecionar, de alguma forma, aqui dentro da instituição, mas, diretamente, nunca trabalhei, nunca fiz nenhum trabalho ${ }^{P 4}$. Minha participação é teórica, de conhecimento teórico, ${ }^{P 1}$ de ouvir as pessoas e saber o que está sendo feito pela equipe através das noticias que chegam ao departamento ${ }^{P 2}$ e levando os alunos para conhecer, ver o que desenvolvem neste projeto ${ }^{P 1}$. Quando tem pesquisas sobre a remoção adequada de resíduos sólidos, eles procuram uma referência que é 
a Equipe de Educação Ambiental ${ }^{p 1}$ e também participo, indiretamente, via alunos. Nas minhas aulas, quando a gente fala da questão das doenças e todos os meios pelos quais você pode adquiri-las,, vem o lixo, vem uma série de outras coisas. A gente está apontando que tem um trabalho aqui, tem uma reciclagem que é feita aqui, ai é importante que eles visitem ${ }^{P 4}$.

\section{DSC A}

Eu acho que a Universidade toda, de uma forma indireta, participa porque todo mundo ter que fazer isto, colocar o lixo no seu devido local ${ }^{\mathrm{A} 3}$, ou seja, a única participação que a gente tem é o fato de colaborar com a coleta seletiva ${ }^{A 2}$, jogando o papel na lixeira azul e o aterro no laranja ${ }^{A l}$. De qualquer forma, separa o que a gente consumiu ${ }^{A 4}$. Em parte, é como obrigação, sim, mas é uma questão de cidadania e para ajudar na limpeza ${ }^{A 3}$. Mas fora esta interação de usar e pedir informação, eu não me vejo participando mais. Eu sou um dos componentes lá da fase final do projeto, não me sinto mais integrada a ele ${ }^{A 1}$. Tirando isto, não existe nenhuma espécie de participação aqui, em termos mais intenso ${ }^{A 2}$.

\section{DSC F}

Participação direta eu não tenho, o que eu tenho é no meu trabalho do dia a dia, as atribuições do meu cargo fazem com que eu tenha a participação no sentido de dar o apoio, dar infra-estrutura para que ele possa ser desenvolvido, mantendo a rotina da coleta, fazendo com que as pessoas entendam que é muito importante a coleta e que respeitem as orientações da Equipe de Educação Ambiental. Isso eu tenho feito e acho que contribuo neste sentido ${ }^{F 3}$.

\section{Idéia Central: Eu participo na separação do lixo e na divulgação do projeto}

\section{DSC F}

Eu participo e acho que todos nós que trabalhamos aqui participamos. Porque, desde quando tem as lixeiras todas padronizadas e tem a preocupação de colocar o lixo na lixeira correta, eu acho que a gente já está participando ${ }^{F 1}$. Então, eu participo, sim, na seleção do lixo ${ }^{F 2}$, jogando o lixo no lugar certo, na separação do lixo ${ }^{F 4, F 5}$, separo papel e estas coisas ${ }^{F 5}$. 
A gente também procura incentivar, não só os alunos, mas os professores e funcionários para que procurem fazer um trabalho sério sobre o processo de seleção do lixo ${ }^{F 1}$. Divulgar que na Universidade existe um projeto ambiental e de que hoje, a Universidade, em termos de limpeza, é em consequiência desse projeto ${ }^{F 4}$. Eu informo as pessoas, quando têm muito papel, que na Educação Ambiental eles fazem seu recolhimento ${ }^{F 5}$.

\section{Idéia Central: Não participo por falta de informação.}

\section{DSC P}

Eu, pessoalmente, procuro, sempre que vejo meu aluno jogando lixo onde não deveria ser jogado, ou deixando sujo o local, orientar no sentido de se colocar o lixo no lugar certo. Mas, mais que isso acho que é impossivel fazer, justamente pela falta de informação, da parte informativa que não está aí para a gente poder chamar a atenção com relação a isso, então eu não teria como participar ${ }^{P 5}$.

\section{Idéia Central: Não participo, só no descarte do lixo.}

\section{DSC A}

Não tenho ligação nenhuma com o projeto de Educação Ambiental. Só nessa questão de utilizar corretamente o que eles propõe, mas eu nunca tive muito contato com eles, mesmo porque eu ficava restritamente no horário de aula ${ }^{A 6, A 8}$. Eu quis dar prioridade ao curso em detrimento do estágio ${ }^{A 8}$. Eu acho que, talvez, seja até uma falha desse projeto, do curso, da instituição não contar com o apoio permanente assim dos estudantes. A gente tem conhecimento de alguns acontecimentos que vão se apresentando, mas eu acredito que não há uma participação efetiva da grande maioria dos estudantes da UEFS ${ }^{A 7}$. Às vezes, a gente esclarece o aluno novo como é feito, já indiquei algumas pessoas para fazer a visita, depois que eu fiz a minha. As pessoas tinham interesse em saber onde é que é feito isso, indicar aos alunos novos do curso, mas o envolvimento efetivo no projeto não tive, eu não vou dizer que tive, só como produtor de lixo ${ }^{A 8}$.

O linico contato que tive foi quando entrei na Universidade. Fui esclarecida tive conhecimento do EEA. Também fui lá algumas vezes porque estou fazendo a 
disciplina com um professor que faz parte da Equipe. Vim outras vezes porque fiz a Feira de Cultura com meus alunos, então a gente tem que estar instruída, peguei material, aprendi a reciclar com o pessoal, busquei e levei material para os alunos, de qualquer jeito estudei, me envolvit ${ }^{\text {A9 }}$.

\section{Análise da questão 4}

Com exceção dos funcionários, que consideram como participação, a separação do lixo, os demais sujeitos consideram essa ação como "participação indireta". Também é considerado como participação indireta: ouvir e saber da equipe sobre suas atividades, levando informações aos alunos ou indicando as atividades do projeto a outras pessoas e, também, utilizando-as como fonte de informação e consulta sobre as questões ambientais.

Contudo, alguns alunos não consideram o descarte de lixo como participação no projeto. Esta atitude seria uma obrigação relacionada à cidadania, no sentido de cumprir um dever. A participação vai mais além e passa pelo envolvimento direto nas ações da equipe, atuando como estagiário, por exemplo. Os alunos que precisam trabalhar para se manter não têm condições de participar dos projetos de pesquisa $\mathrm{e}$ de extensão realizados pela Universidade. Logo, têm menores oportunidades de conhecer o projeto.

Os funcionários, como estão permanentemente presentes no dia a dia da Universidade, criaram o hábito de armazenar o papel dentro de seu setor de trabalho para posterior coleta do encarregado desse serviço, quando avisado previamente. Esta estratégia de comunicação prévia foi adotada desde o início do projeto, na qual o funcionário de coleta vai buscar, diretamente na fonte geradora, o papel acumulado. 


\subsubsection{O Discurso do Sujeito Coletivo na avaliação do projeto.}

Através da pergunta, "Em que aspecto o projeto poderia ser melhorado? Fale-me sobre isto", a comunidade universitária pôde avaliar e indicar possíveis melhorias para o melhor desempenho do projeto. As idéias centrais estão relacionadas no quadro 9.

Quadro 9 - Idéias Centrais expressas pelos professores, alunos e funcionários da UEFS sobre os aspectos em que o projeto poderia ser melhorado.

\begin{tabular}{|c|c|}
\hline Sujeito & Idéia Central \\
\hline $\begin{array}{l}\text { Professor } \\
\text { (P) }\end{array}$ & $\begin{array}{l}\text { 1. O projeto precisa ter mais visibilidade e uma maior } \\
\text { divulgação; } \\
\text { 2. O projeto tem que ser mais educativo; } \\
\text { 3. O projeto deve extrapolar os muros da Universidade. }\end{array}$ \\
\hline $\begin{array}{l}\text { Aluno } \\
\text { (A) }\end{array}$ & $\begin{array}{l}\text { 1. O projeto precisa ter mais visibilidade e uma maior } \\
\text { divulgação; } \\
\text { 2. O projeto deve extrapolar os muros da Universidade. }\end{array}$ \\
\hline $\begin{array}{l}\text { Funcionário } \\
\text { (F) }\end{array}$ & $\begin{array}{l}\text { 1. O projeto precisa ter mais visibilidade e uma maior } \\
\text { divulgação; } \\
\text { 2. O projeto deve extrapolar os muros da Universidade; } \\
\text { 3. Treinamento dos funcionários de limpeza. }\end{array}$ \\
\hline
\end{tabular}

Idéia Central: $O$ projeto precisa ter mais visibilidade e uma maior divulgação

\section{DSC P}

Depois de tudo que a gente falou sobre o processo, tem que ter paciência, ter metas conscientes, mudança de cultura, mudança de paradigma não é uma coisa que vai acontecer facilmente, é um processo bem lento, de mudança gradual e qualquer vitória tem que ser comemorada. Agora, o processo tem que ser mais transparente, as ações da EEA têm que ser mais transparentes ${ }^{P 2}$, têm que ter mais visibilidade ${ }^{P 3}$. 
Eu acho que são mais transparentes para fora do que para dentro da própria Universidade. Participam de Congresso, vem gente de fora buscar informação e, aqui dentro, não é tão valorizado como deveria, como é valorizado por outras Universidades, de outros centros e de locais que têm contato com o trabalho da $E E A^{P 2}$.

Alguns anos atrás, eu acho que tinha mais visibilidade e depois parou de ter. Então, ficou só a coisa da latinha. A latinha, eu acho que as pessoas não ligam muito, usam como lata de lixo e aí nem lêem o que está ali, nem sabem porque é colorido, nem nada ${ }^{P 3}$, então tem que se voltar a informar às pessoas. Os alunos entram e saem daqui semestralmente, então, todo o semestre esse aluno que chega deveria ser informado e ser devidamente orientado para isso. Eu acho que a EEA poderia, também, encontrar meios de atrair a população universitária para conhecer, inclusive, a estrutura do projeto, participar mais diretamente dele. Oferecer cursos, ateliês, divulgar o próprio material que é produzido no EEA, chamando a atenção dessa comunidade, para poder visitar o que é o processo. Isso faz parte também da comunicação, de uma boa campanha de divulgação, uma boa campanha de promoção, uma boa campanha de sedução, realmente, das pessoas que compõem a Universidade ${ }^{P 5}$.

$O$ aluno não conhece, o professor e o funcionário não conhecem a EEA, nem o próprio prédio da EEA. Pensei, também, no pessoal da noite. O pessoal do diurno já não tem acesso ou não tem a iniciativa de chegar lá para ver o que é e como funciona. Imagine o pessoal do notumo? Porque o prédio fica num local que não é estratégico $^{P 5}$. Acho que o grande pecado da EEA é não saber vender o peixe, acho que tem que pegar alguém de marketing e tornar mais transparentes suas ações, para aumentar o envolvimento das pessoas. Quem conhece um pouco se encanta com o projeto ${ }^{P 2}$.

\section{DSC A}

Eu acho que ele tem que voltar a fazer maior divulgação, fazer trabalhos na própria comunidade universitária, eu estou sentindo falta dele ${ }^{A 1}$. Eu acho que a divulgação é pouca, a equipe responsável está preocupada em melhorar, mas não há muita divulgação ${ }^{A 3}$. Eu não sei, por exemplo, como está a compostagem, como está 
se utilizando, isto é, nem mesmo os produtos que o pessoal tem feito, não tenho visto $^{A l}$. Eu acharia interessante a gente saber do projeto até o fim, para onde vão todos esses resíduos, o que é feito ${ }^{A 4}$. Eu acho que a primeira coisa que ele deveria fazer é tentar envolver os membros da própria academia, integrar de alguma forma, não sei se em forma de bolsa ou de desenvolvimento de projeto ${ }^{A 2}$. Está precisando mostrar o que está se fazendo para a gente e integrar mais as pessoas para que elas se sintam mais atuante como se fossem parte do projeto também ${ }^{A l}$. Eu acho que quando a gente se sente parte de qualquer idéia, pode trabalhar melhor, pode ajudar, caso contrário, talvez ele nem funcione, porque a coisa se torna assim inconsciente ${ }^{A I}$. Deveria ter mais palestras, informar mais aos estudantes, porque é importante para que a gente conheça mais a realidade, deixar a Universidade mais informada sobre o que é esse projeto de Educação Ambiental ${ }^{43}$. Eu acho muito limitado, não se tem informação de palestras que sejam promovidas e abertas para a comunidade junto com os DAS ${ }^{46}$. Geralmente, quem é mais ligado são os alunos que fazem biologia ${ }^{A 9}$. A Educação Ambiental também deveria ser aberta de uma forma que todos participassem e pudesse se inteirar mais sobre a questão do que é Educação Ambiental e que proposta eles têm aqui dentro da Universidade ${ }^{A 6}$. A educação tem que ser contínua. Eu não vejo uma continuidade, um esclarecimento. Os novos alunos que entram na faculdade, não sei se estão recebendo essa orientação, existe a TVU que eu nem sei como é que está, se está funcionando e que deveria estar constantemente falando sobre isso ${ }^{A 8}$.

O que poderia ser melhorado, é essa questão da participação; sem dúvida, é algo que deveria ser mais bem pensado. Quando eu falei na participação é no sentido de uma interação maior entre as pessoas que estão na organização, no gerenciamento desse programa com a comunidade. Como, por exemplo, com a apresentação de seminários ${ }^{A 7}$.

\section{DSC F}

Uma coisa em que o projeto poderia ser melhorado é em relação a programação visual. Eu acho que a programação visual para divulgar a coleta seletiva não foi muito bem assimilada. Eu não sei se é por conta dessa programação que não é eficiente, ou se falta alguma coisa ${ }^{F 3}$. Também tem que ter mais divulgação 
nos setores, tem muita gente nova ${ }^{F 5}$ e uma divulgação maior do que a EEA produz, sobre o adubo orgânico, uma divulgação e uma comercialização desses produtos ${ }^{F 4}$.

\section{Idéia Central: Tem que se mais educativo}

\section{DSC P}

Eu acho que o projeto tem que ser mais educativo ainda, eu acho que está sendo pouco educativo ${ }^{P 3}$, proporcionar uma conscientização maior dentro da Universidade, uma coisa maior, para se tornar bem mais ostensiva. Todo mundo está vendo que tem de separar, está vendo que tem que reciclar,mas você está vendo pessoas jogando a coisa do outro lado, até fora da lixeira está acontecendo ${ }^{P 4}$. Ele tem que provocar, nas pessoas, um certo constrangimento com o comportamento que cada um tem em a relação ao seu próprio lixo, ao lixo que ele próprio produz. Que provoque mais as pessoas a se tocarem mesmo e, a partir dai, mudar o comportamento, ou ter a curiosidade de saber porque que tem que reciclar, porque que tem que ter coleta seletiva, porque que tem que ter um depósito de lixo ou uma usina de beneficiamento de lixo. Porque é importante a relação disso com questão do meio ambiente. Eu acho que o meio ambiente, hoje, século XXI, é a nossa grande discussão daqui para frente. A gente está vendo cada vez mais a degradação das cidades $e$ isso está começando a atingir profundamente as pessoas, com as epidemias, endemias, doenças e mais doenças aí voltando, matando, dizimando e tal. Então eu acho que precisa ter alguma coisa dentro do projeto que faça isso aparecer mais, ter algumas coisas mais duras, mais incisivas, mais educativas, algumas coisas que envolvam mais a comunidade universitária e alguma coisa mais leve, mais lúdica através de teatro, dança, de alguma performance e que as pessoas se sintam parte integrante daquilo ali e acabe se envolvendo e gostando. Que aquilo fique registrado na memória dele e ele vai passando adiante, eu acho que é alguma coisa por $a i^{P 3}$.

\section{O projeto deve extrapolar os muros da Universidade}

DSC P 
A EEA poderia atuar de forma mais efetiva, não apenas na Universidade que é importante. Mas se toda essa produção de conhecimento extrapola os muros da Universidade, ganha a comunidade, ganha a própria Universidade, ganha todo mundo de um modo geral. Está evitando doença, a gente está fazendo uma série de coisas, trazendo benefícios $^{P 5}$. Pelo menos conscientizar o pessoal do bairro. Aqui o pessoal é privilegiado, tem conhecimento, poderia estender mais para a população feirense, para melhorar este destino de lixo a céu aberto que a gente vê muito, lixo em Feira Livre. Então, el acho que deveria estender mais esta educação permanente para a comunidade,para a população de maneira geral $^{P I}$.

$O$ projeto pode e deve necessariamente atingir as escolas de ensino médio e ensino fundamental, nas disciplinas de ciências, nas disciplinas de biologia onde trabalham com ecologia e com Educação Ambiental também. Até nas séries inicias e, então, a EEA poderia ser melhor aproveitada, não apenas na Universidade, mas na comunidade de Feira de Santana também, E promover essas mudanças. Toda essa discussão que a gente teve aqui com relação aos cestinhos, a separação do lixo, e sua reciclagem pode e deve ser desenvolvida na escola de ensino fundamental, do ensino médio ${ }^{P 5}$.

\section{DSC A}

Na UEFS, tem recipiente em todos os lugares e tem ampla divulgação. São vários cartazes, eu acho suficiente. Mas, poderia abranger mais a conscientização das pessoas. Na UEFS não circulam somente pessoas do mundo acadêmico, tem pessoas de outro local que não estão ligadas a este projeto. Pelo menos na comunidade perto, que freqüenta mais a UEFS, poderia ter uma divulgação um pouco maior ${ }^{A 5}$ e, acima de tudo, expandir e difundir isso aí pela região de Feira de Santana, extra-campus para não ficar só como projeto piloto. Já tem tempo suficiente para sair dessa fase de estudos e atingir a sociedade que é o alvo ${ }^{\text {A8 }}$.

\section{DSC F}

Aqui dentro da Universidade eu acho que não está faltando nada, mas deveria divulgar e também ensinar as pessoas nas comunidades, em cidades vizinhas, em bairros, a separação do lixo e fazer ali um núcleo de reciclagem desse 
lixo. Porque aí tem o adubo orgânico que venderia, a reciclagem do papel, latas, garrafas, plástico também, e aí pronto. Só falta divulgação e comercialização do $l_{i x o^{F 4}}$. Eu acho que deveria procurar as autoridades municipais, estaduais e, até, federais para que elas dessem um apoio para que esse projeto venha melhorar o município de Feira de Santana e a micro região de Feira ${ }^{F 2}$.

\section{Idéia Central: Treinamento das funcionárias de limpeza}

\section{DSC F}

Que as serventes sejam treinadas para que façam a seleção e recolham o lixo separado para não colocar tudo misturado quando forem fazer a limpeza nas salas,. O setor tem cuidado de separar os lixos e elas vêm colocam tudo em um saco sófl.

\section{Análise da questão 5}

Através da análise do discurso do sujeito coletivo sobre em que o projeto poderia ser melhorado, pode-se depreender:

- As ações da Equipe de Educação Ambiental devem ser mais visíveis através de informações contínuas sobre o destino de cada resíduo, para possibilitar o envolvimento da comunidade universitária com o projeto, sentindo-se parte do processo.

- Atrair as pessoas para conhecer o espaço onde o lixo é processado, oferecendo cursos e oficinas de reciclagem de lixo, divulgando o material que é produzido pela EEA.

- Promover palestras e seminários evolvendo os Diretórios Acadêmicos (DAS) com o objetivo de discutir o processo. Conforme CANIATO, citado por SORRENTINO (1998 p.31), "Entre as várias ações que devem ser estimuladas, uma, particularmente importante, é a discussão. A discussão ativa o pensamento crítico e desencadeia outras iniciativas...Uma boa discussão pode ser, portanto, uma ótima oportunidade para se iniciar um processo de renovação ativa na prática de uma educação mobilizadora...". 
- Utilizar, como instrumento de sensibilização e de reflexão das questões ambientais, expressões artísticas, como teatro, dança, etc.

- Repensar a programação visual da estrutura para a coleta seletiva, modificando-a periodicamente.

- As campanhas de sensibilização devem ser educativas, através de abordagens sobre a problemática do lixo e suas implicações no meio ambiente e na saúde pública.

- Treinamento do pessoal da limpeza dos setores para evitar que eles não misturem lixo previamente segregado, inviabilizando a recuperação dos resíduos.

Interessante observar que há uma preocupação geral dos sujeitos em relação aos alunos novos e muitas recomendações sobre a adoção de estratégias de informação que atendam a esse público. Contudo, não é percebido nos discursos dos professores e dos alunos, qualquer responsabilidade com isto, dando a impressão de que o projeto é da EEA ou da Universidade, e que não lhes pertence.

Um fato que chama a atenção é que, nos discursos onde os sujeitos percebem que a coleta seletiva está se realizando de forma adequada, há, por parte dessas pessoas, o desejo de que o projeto não se restrinja somente à Universidade e seja implantado em comunidades e escolas da região de Feira de Santana. 


\subsubsection{O Discurso do Sujeito Coletivos sobre a relação pessoal com o lixo}

"Lixo, você tem alguma coisa a ver com isto? Fale-me sobre isto". Esta pergunta foi feita aos entrevistados para observar a relação deles com o lixo.

Quadro 10 - Idéias Centrais expressas pelos professores, alunos e funcionários da UEFS sobre sua relação com o lixo.

\begin{tabular}{|c|c|}
\hline Sujeito & Idéia Central \\
\hline $\begin{array}{l}\text { Professor } \\
\text { (P) }\end{array}$ & $\begin{array}{l}\text { 1. Tenho, todo mundo tem a ver com o lixo. Eu produzo e devo } \\
\text { manuseá-lo adequadamente; } \\
\text { 2. Todo mundo tem a ver com o lixo. Lixo é uma questão de } \\
\text { cidadania. }\end{array}$ \\
\hline $\begin{array}{l}\text { Aluno } \\
\text { (A) }\end{array}$ & $\begin{array}{l}\text { 1. Tenho. Eu produzo e tenho que me preocupar com seu destino; } \\
\text { 2. Todo mundo tem a ver com o lixo. Lixo é uma questão de } \\
\text { cidadania; } \\
\text { 3. Lixo, como um dos problemas ambientais e de saúde. }\end{array}$ \\
\hline $\begin{array}{c}\text { Funcionário } \\
\text { (F) }\end{array}$ & 1. Todos nós temos a ver com o lixo \\
\hline
\end{tabular}

Idéia Central: Tenho, todo mundo tem a ver com o lixo. Eu produzo e devo manuseá-lo adequadamente

\section{DSC P}

Eu tenho tudo a ver com isso ${ }^{P 4}$, porque eu produzo lixo ${ }^{P 1, P 5}$ e, cada vez, se produz mais lixo. A própria indístria de consumo nos obriga a produzir mais lixo ${ }^{P I}$ e eu sou vítima do lixo que você produz ${ }^{P 5}$. Ambiente é o lugar onde a gente convive, então tem que se preocupar como vai ser removido este lixo. Se a gente está fazendo uma remoção adequada desses resíduos sólidos, também está melhorando, não só a parte estética, mas melhorando economicamente, porque está se aproveitando o lixo $^{P l}$, porque tudo é descartável, tudo você joga fora, quase nada é reaproveitável. Quando é reaproveitável tem até escrito lá na garrafinha e tal, é reciclável, mas você acaba jogando aquilo fora ${ }^{P 3}$. O que está indo para o lixo realmente, é para ir 
para o lixo? E onde a gente vai jogar esse lixo? ${ }^{P 4}$. O que é lixo para a gente é matéria prima para alguém: os catadores de lixo. A gente tem que pensar nisto também, não é uma coisa longe da gente ${ }^{P l}$.

Então, eu acho que todos nós somos completamente responsáveis para buscar soluções, não produzir tanto lixo, o que for produzido, ser o mínimo, poder reciclar o máximo, poder transformar o máximo, dar uma outra utilidade, reutilizar e aquele minimozinho que não tem jeito mesmo, aí, sim, seria aquele lixo descartado ${ }^{P 3}$. Eu acho que a gente poderia ter uma outra consciência, por exemplo existe lixo orgânico que eu produzo em minha casa e esse lixo orgânico poderia ser reciclado por mim mesmo dentro de casa porque aquele lixo orgânico que eu produzo é adubo. Diariamente, nós estamos produzindo e se nós tivéssemos uma informação maior, uma consciência maior, muitas vezes uma estrutura maior, você vê mesmo que no centro da cidade nós não temos uma estrutura que nos possibilite desfazer do lixo ${ }^{P 5}$.

\section{DSC A}

Acho que todos nós temos a ver com o lixo ${ }^{A 2}$, nós produzimos e somos responsáveis por esse lixo e deve haver uma grande preocupação de onde vai parar esse lixo ${ }^{A 6}$. Acho que o lixo é sempre tratado como se fosse um problema da prefeitura, como se nós não tivéssemos nada a ver. Só que nós vivemos em uma sociedade altamente consumista, produzimos quilos de lixo por ano, produzimos lixo $^{A 1}$ a cada segundo. Em qualquer lugar que a gente esteja, estamos produzindo lixo $^{A 2}$. A gente consome a coisa pronta, industrializada, produzida, limpa e pode descartar uma coisa contaminada, ruim, tóxica e está jogando no ambiente ${ }^{A 4}$. Nós somos produtores de lixo e não nos preocupamos com o destino final dele ${ }^{A 1, A 2}$. A gente não tem essa preocupação, é como se fosse algo que estivesse externo à nossa vida, basta fazer a limpeza da nossa porta e não interessa onde o lixo está; só queremos saber se a prefeitura tirou da nossa porta, se colocou adiante. Não interessa onde ele está sendo disposto, ninguém quer saber nada disto ${ }^{A 2}$. Então o lixo é parte integrante da nossa vida em todos os momentos e a gente não se preocupa muito com isto. 
Lixo é tudo que a gente gera e acha que não presta. Se as pessoas tomassem um pouquinho mais de consciência de que a maior parte do lixo pode ser reaproveitada, porque a maioria do lixo que produzimos é matéria orgânica e pode ser usada em inúmeras funções, se todo mundo pensasse assim, poderia ser melhorado o problema da fertilidade do solo, a eutrofização de lagos. A gente tem muito a ver com isto, tem muita responsabilidade com o lixo que produz ${ }^{A S}$ e tem que dar algum destino a ele. Eu sou consumidor e sou cidadão, eu tenho que olhar para a sociedade, no presente, principalmente, e no o futuro. Se a natureza não tem como decompor ou reciclar esse lixo com a mesma velocidade com que a gente produz, nós temos que dar nossa mãozinha de contribuição, temos que acelerar esse processo de reciclagem, ajudar a natureza a fazer e consertar, porque, afinal de contas, nós é que estamos produzindo, e em velocidade altíssima. Se a gente não pode evitar esse crescimento populacional como ele acontece, conseqüientemente gerando lixo em quantidades cada vez maiores, a gente tem que ter uma intervenção nisso aí, para poder manter esse equilíbrio, equilibrio homem-natureza, é isso que a gente tem a ver, eu só não, cada cidadão, cada ser humano ${ }^{A 8}$.

Eu acho que a gente poderia fazer muita coisa para diminuir esta quantidade de lixo. O que a gente puder fazer para diminuir, então temos muito a ver, podemos melhorar bastante. Agora, nem todo mundo tem consciência disto. Muita gente tem até boa vontade, mas o que vai fazer com este lixo todo? Aquela garrafa descartável que pode não ter significado, para outros tem ${ }^{A 9}$. Eu acho esse controle do lixo, hoje, muito importante. Então, você deve ter um lugar separado, um local adequado para armazenamento desse lixo, estocagem dele, seleção, eu não sei ${ }^{A 6}$.

\section{Idéia Central: Todo mundo tem a ver com o lixo. Lixo é uma questão de}

\section{cidadania}

\section{DSC P}

Todo mundo tem a ver com o lixo. Lixo é uma questão de cidadania. Acho que tem que ser discutido, debatido e só vai ser potencialmente resolvido quando houver um debate profundo sobre esta questão. $\grave{A}$ medida que aumenta o desenvolvimento da sociedade e a capacidade de consumo, a geração de lixo 
aumenta. É um debate que se tem nos países do primeiro mundo, pela cultura do modelo capitalista principalmente americano, que tem uma capacidade de gerar descartável, muito maior que a nossa, e que produz milhões e milhões de dólares em lixo. Eu acho que temos que estar atentos a isto e buscar um novo modelo. Para mim, a questão do lixo vinculou-se à questão de cidadania e, como tal, deve ser discutida e debatida com a sociedade, os estados, o governo municipal que estão mais ligados com os problemas do dia a dia, e o lixo está ligado às coisas do dia a dia. Não depende tanto de macro políticas, depende de ações mais localizadas, é uma coisa que envolve aquele espaço, tem que ter grandes diretrizes gerais, mas as ações, em si, são localizadas e o estado tem que saber interagir com a sociedade. Acho que tem que procurar um modelo de cidadania, de participação da sociedade, e só vai ser resolvido quando o lixo for incorporado como coisa cidadá. Como, realmente, o lixo tem a ver com seu dia a dia e você tem que assumir sua parcela de geração naquela comunidade, você não deve deixar o lixo como responsabilidade só do governo, o governo tem que tirar o lixo da rua ${ }^{P 2}$.

Aliás, a questão do lixo é um bom gancho para discutir, inclusive, outras questões do modo de vida, de fazer política no país. Você pode discutir outras questões como educação, como emprego e geração de renda, de ações de saneamento, tudo a partir da ótica da participação, pois é um problema que afeta todo mundo e no momento em que as pessoas se juntam para discutir o assunto, sobre o lixo, elas descobrem que podem discutir educação, moradia, segurança. $O$ lixo é um bom gancho e se ele está na sua porta e o aflige no dia a dia, ele tem um grande potencial de ser um catalisador para discutir as questões de cidadania ${ }^{P 2}$.

\section{DSC A}

Tenho tudo a ver com isso. Todo o mundo é cidadão, então todo o mundo tem a obrigação de contribuir para a limpeza do local em que vive. Lugar de lixo é no lixo. É uma questão de cidadania e até de limpeza pessoal, porque ninguém se sente feliz e bem em local sujo, em um local porco. Cidadania é o cumprimento de dever para exigir seus direitos. Se, então, é uma obrigação minha contribuir para a 
limpeza, eu devo contribuir e, se isto não tiver correndo bem, eu posso exigir para que seja tudo direitinho ${ }^{A 3}$.

\section{Idéia Central: Lixo como um dos problemas ambientais e de saúde}

\section{DSC A}

A questão do lixo é uma questão muito discutida hoje, principalmente em relação à degradação ambiental. A gente sabe que a questão do lixo é uma questão muito delicada e que deve ser tratada com mais responsabilidade, principalmente pelos administradores públicos. Sabemos que a realidade nossa é diferente da de países considerados desenvolvidos onde a questão da consciência com o lixo é mais forte. Mas sabemos, também, que lá a preocupação com o meio ambiente no seu aspecto geral, também não é permanente. Por exemplo, os Estados Unidos, se recusaram a aderir ao pacto de Quioto. Com certeza, tenho a ver com o lixo porque hoje, transitoriamente, faço parte da comunidade de Feira de Santana e tenho que dar a minha contribuição para com este ecossistema, que deve ser preservado. Isso é um papel que cabe a todos, não somente a um segmento especial da nossa sociedade $^{A 7}$.

Outra coisa que me tocou muito quando se fala em lixo: a gente fez uma visita ao aterro sanitário e vi aquelas pessoas que trabalham lá e se alimentam daquilo. A gente fica pensando na responsabilidade que se tem também com estas pessoas e com o próprio ambiente em que a gente vive e com o próprio planeta ${ }^{A 1}$. Em uma comunidade, o lixo era jogado em ruas, em terrenos baldios, então estava trazendo leptospirose por causa dos ratos e as crianças estavam contraindo ameba, certas doenças, por estarem em contato com esgotos abertos. Eu acho esse controle do lixo hoje muito importante ${ }^{A 6}$. Então, quando a gente tem uma alternativa que ele possa melhorar e não causar um dano tão grande ao ambiente, eu vivo tentando fazer isto. Lixo é uma coisa que me toca. É uma preocupação muito grande ${ }^{A l}$. 


\section{Idéia Central:Todos nós temos a ver com o lixo}

\section{DSC F}

Eu tenho ${ }^{F 2, F 3, F 4, F 5}$ eu acho que todo mundo tem a ver com o lixo ${ }^{F l, F 5}$ porque as pessoas têm que se educar, saber selecionar o lixo ${ }^{F I}$. Eu mesmo, em casa, faço a seleção, na hora de distribuir o lixo e botar na porta para o carro levar, eu sempre coloco em sacos diferentes ${ }^{F 2, F 5}$, porque nós, fazendo isso, estamos beneficiando a nós próprios ${ }^{F 2}$ e mais ainda, em saber que este lixo está sendo aproveitado, reaproveitado ${ }^{F 4}$. Também em relação à limpeza ${ }^{F 1}$, por você se sentir bem em lugar limpo ${ }^{F 4}$. Se a gente for uma pessoa suja, isso aí vai trazer doenças ${ }^{F 1}$ provenientes do lixo, a dengue está aí, de latinha sem uso ${ }^{F 4}$.

Eu tenho muito a ver por conta de manter a Universidade limpa eu sinto falta de não ter um aproveitamento melhor desse lixo e acho que a gente tem que caminhar para isto, a gente tem muito desperdicio dele. Embora tenha coleta seletiva a gente joga muito lixo fora, poderia ser muito mais aproveitado ${ }^{F 3}$

\section{Análise na questão 6}

Nos discursos sobre a responsabilidade dos indivíduos na questão do lixo, observa-se que a mesma está relacionada com:

- Remoção do lixo do ambiente para melhoria da estética e também para evitar doenças.

- Deve haver um conhecimento sobre o destino dado ao lixo gerado pela sociedade

- Sua geração está relacionada com a indústria de descartáveis e, conseqüentemente, com uma sociedade de consumo, obrigada a produzir cada vez mais lixo

- Lixo como conseqüência do crescimento populacional.

- Além do governo, a sociedade é responsável para buscar soluções sobre a problemática dos resíduos sólidos.

- A reciclagem, como solução do problema e como forma de ajudar a natureza

- A responsabilidade de todos no sentido de gerar o mínimo possível de lixo. 
- Diminuir o volume de lixo para coleta pública através da adoção da compostagem doméstica, embora não seja uma ação realizada pelos sujeitos.

- Sensibilização com relação às pessoas que vivem em lixões e, muitas vezes, se alimentando das sobras dos outros.

- Importância da informação, estrutura para recebimento do resíduo.

- Impotência frente à problemática que envolve os resíduos por não saber como evitar a geração deles.

O lixo foi lembrado como questão de cidadania tanto no seu sentido mais restrito de cumprir deveres e exigir direitos (responsabilidade sobre a limpeza do ambiente) como em sentido mais amplo, como um gancho para participar na solução do problema que envolve questões locais, isto é, como tema gerador de discussão de outras questões que afetam a sociedade. Acredita-se que esse deve ser o objetivo dos projetos de Educação Ambiental voltados para a problemática do lixo urbano, como pode ser extraído do DSC dos professores quando o relacionam com questão de cidadania: "o lixo é um bom gancho para discutir outras questões como o modo de vida, a política no país, a educação, o emprego e a geração de renda, de ações de saneamento, tudo a partir da ótica da participação, pois é um problema que afeta todo mundo e no momento em que as pessoas se juntam para discutir este assunto, elas descobrem que podem discutir educação, moradia, segurança. O lixo é um bom gancho e, se ele está na tua porta e ele te aflige no dia a dia, ele tem um grande potencial de ser um catalisador para discutir as questões de cidadania". 


\subsubsection{Conclusão}

Passados mais de 10 anos da implantação do Projeto Coleta Seletiva e Reaproveitamento do Lixo na Universidade Estadual de Feira de Santana, observa-se que a Educação Ambiental praticada na UEFS, tendo como eixo central a questão dos resíduos sólidos, se por um lado proporcionou a formação de hábitos responsáveis no descarte do lixo - não jogar o resíduo no chão - por outro, não conseguiu promover a compreensão das causas dos hábitos consumistas e de incorporar, de maneira geral, no dia a dia da comunidade universitária, a prática do seu descarte segregado. Os motivos principais apontados e observados são:

- As ações educacionais desenvolvidas são mais voltadas para a mudança de comportamento individual. Essa prática linear: informação = mudança de comportamento, é transitória, isto é, pode ter um impacto inicial sobre os indivíduos, contudo, ao longo do tempo, tende a uma acomodação, a uma volta ao comportamento inicial;

- A própria dinâmica das Universidades, que têm parte de sua população renovada, a cada semestre, pelo ingresso de novos alunos, necessita de estratégias educacionais contínuas, renovadas e criativas;

- Um dos espaços propícios para estimular a interlocução e o diálogo com a comunidade universitária é a sede da EEA, contudo sua localização é afastada dos locais de maior circulação de pessoas no campus;

- As campanhas de sensibilização realizadas na UEFS têm como foco principal o calouro. Como o processo educativo deve ser contínuo, as campanhas devem buscar atingir, mais fortemente, os alunos, independente do tempo de vivência na instituição;

- Os cursos noturnos são pouco contemplados com as atividades de sensibilização realizadas pela Equipe;

- A inexistência de parcerias entre a EEA e os Diretórios Acadêmicos para a promoção de discussões com os estudantes sobre as questões ambientais;

- Os cartazes são uma forma facilitadora de comunicação com a comunidade universitária, contudo deve-se ter o cuidado quanto ao caráter normativo dos 
conteúdos presentes na maioria dos utilizados na UEFS, para que a coleta seletiva não pareça uma imposição e, sim, permita a reflexão sobre a problemática dos resíduos sólidos no ambiente e na saúde, induzindo a comunidade a tomar consciência de seu papel frente ao problema;

- Pouco incentivo dado à estratégia de minimização dos resíduos no conteúdo dos materiais impressos, o que pode ter levado a comunidade universitária a incorporar valores no sentido de que a reciclagem é a solução, excluindo dela a responsabilidade no enfrentamento da problemática do lixo;

- Pouca renovação da programação visual dos coletores e adesivos explicativos, necessários à coleta seletiva;

- Pouca divulgação dos resultados da coleta seletiva, do processo de gerenciamento do lixo na UEFS e das ações da Equipe de Educação Ambiental, o que é fundamental como retroalimentador do processo;

- A Administração Superior da UEFS não contempla, no planejamento, nem nos projetos de novos prédios, a infra-estrutura para a coleta seletiva. Com isso, os locais, depois de construídos, ficam, por um período, sem os acondicionadores necessários para o descarte adequado dos resíduos;

- A desorganização da segregação dos resíduos nas cantinas provocada, tanto pelos seus usuários, como pelo locatário. Recentemente, na licitação para prestação de serviços nas cantinas, foram incluídos tópicos referentes às obrigações do locatário com o manejo do lixo, inclusive com previsão de multas;

- A inexistência de um programa de capacitação contínua direcionada aos funcionários de limpeza da UEFS. Esses funcionários são terceirizados e, devido a isso, há uma rotatividade dos mesmos dentro da UEFS;

- Pouca utilização dos dados obtidos na avaliação do projeto. Os dados quantitativos de segregação do lixo aterro e os proporcionados pelas pessoas como pensam e como agem - realizados por meio de entrevistas ao longo do projeto, foram pouco utilizados. Muitas das entrevistas não foram, sequer, compiladas e analisadas.

Os pontos positivos a serem destacados são a rotina de armazenamento diferenciado dos papéis, pelos funcionários administrativos da UEFS, e a 
comunicação com a EEA para viabilização da coleta desse resíduo. Observa-se, também, que as pessoas que se sentiram influenciadas pelo projeto, declararam que não conseguem mais jogar o "lixo no chão", ficando incomodadas com a falta de lixeiras em locais públicos, e que essa consciência se iniciou devido ao projeto desenvolvido na UEFS. Mesmo as pessoas que dizem já possuírem uma consciência ambiental afirmam que projetos dessa natureza são importantes para solidificá-la. Nesse contexto, a limpeza do campus é uma mudança positiva observado nos discursos, sendo creditado ao projeto de coleta seletiva desenvolvido na UEFS.

A criação da Equipe de Educação Ambiental e a implantação do projeto contribuíram para a visibilidade da Universidade à comunidade externa e a outras Universidades quanto às questões ambientais e ao manejo de resíduos sólidos urbanos em particular. Do trabalho inicial com o lixo, emergiram muitas demandas da sociedade, como o Curso de Especialização em Educação Ambiental que se iniciou no ano de 2000 e continua sendo oferecido, de forma regular, e também trabalhos de capacitação e mobilização comunitária. Essas novas ações devem ser mais divulgadas para atrair outros professores e alunos que tenham interesse em trabalhar com a questão dos resíduos sólidos e nas outras linhas de pesquisa e extensão desenvolvidas pela EEA. O projeto no campus chama a atenção do alunado e tem proporcionado a uma parcela de estudantes da UEFS, oriundos de diferentes cursos de graduação, estágios, tanto em pesquisa, como em extensão.

As atividades de extensão realizadas pela EEA foram lembradas como realizações positivas. A Equipe tem difundido as questões de resíduos sólidos para a comunidade externa da UEFS por meio de: palestras, consultorias, exposição de materiais reciclados e oficinas de papel artesanal em Feiras de Cultura nas escolas e em eventos ambientais nos municípios, nas indústrias e em eventos científicos, entre outros. Também, oferece no espaço de sua sede, a oportunidade de, in loco, observarem-se as principais atividades relacionadas à recuperação dos resíduos sólidos coletados: o armazenamento dos recicláveis, a fabricação de produtos de papel reciclado (embalagens, cartões, cestas,...) por meio da oficina de papel, a compostagem dos resíduos orgânicos e as atividades promotoras da Educação Ambiental, no sentido de informação, divulgação e capacitação do público interno da Universidade e de visitantes externos. Essa unidade conta com acervo bibliográfico 
sobre questões ambientais, sendo que algumas publicações resultaram da ação da Equipe de Educação Ambiental e apresenta exposição permanente dos produtos ali produzidos.

A continuidade do projeto, ao longo desses anos, foi possível pela dedicação de professores, funcionários e alunos estagiários que ainda acreditam na importância ambiental e educacional que o manejo adequado dos resíduos sólidos tem para a sociedade.

As representações do lixo observadas na Universidade foram:

- Representação do lixo como parte da vida dos seres humanos: os seres humanos são, por natureza, produtores de lixo, sendo cada vez mais incentivados a produzi-lo pela indústria de consumo;

- A Representação do lixo como fonte de renda: o lixo como fonte de renda para a população informal dos catadores, situação essa vista como uma condição humana degradante e como um problema social brasileiro;

- A Representação do lixo que não é lixo (que pode ser reaproveitado/reciclado): deve-se ter responsabilidade com a sua geração (minimização), reaproveitamento e reciclagem, tendo-se preocupação com o seu destino;

- Representação do lixo como questão de cidadania: cada um deve ser responsável pela parcela de lixo que gera e com a limpeza do ambiente, e, como o lixo faz parte do dia a dia dos seres humanos, ele pode ser um bom gancho para se discutir o modo de vida, a educação, a renda, entre outras questões, que afetam a sociedade;

- Representação do lixo como problema ambiental e de saúde pública: o lixo é uma das causas da degradação ambiental e de problemas de saúde. 


\subsection{PROJETO DE EDUCAÇÃO AMBIENTAL NO ARRAIAL DE SÃO FRANCISCO DA MOMBAÇA - BAHIA}

\subsubsection{Caracterização do Arraial de São Francisco da Mombaça}

O Arraial de São Francisco da Mombaça pertence ao município de Conceição do Almeida, do qual está a uma distância de $4 \mathrm{~km}$. Este município dista $170 \mathrm{~km}$ de Salvador, ocupa uma área de $262 \mathrm{~km}^{2}$ e está localizado no Recôncavo Baiano, tendo como limites os municípios de São Felipe, Varzedo, Dom Macedo Costa, Sapeaçu, Castro Alves e Santo Antônio de Jesus (ACASFMombaça 2000).

A população do município de Conceição do Almeida é de 18.865 habitantes, sendo 9.265 homens e 9.600 mulheres. Da população total, 8.293 vivem na zona urbana e 10.572 na zona rural (SEI 2002).

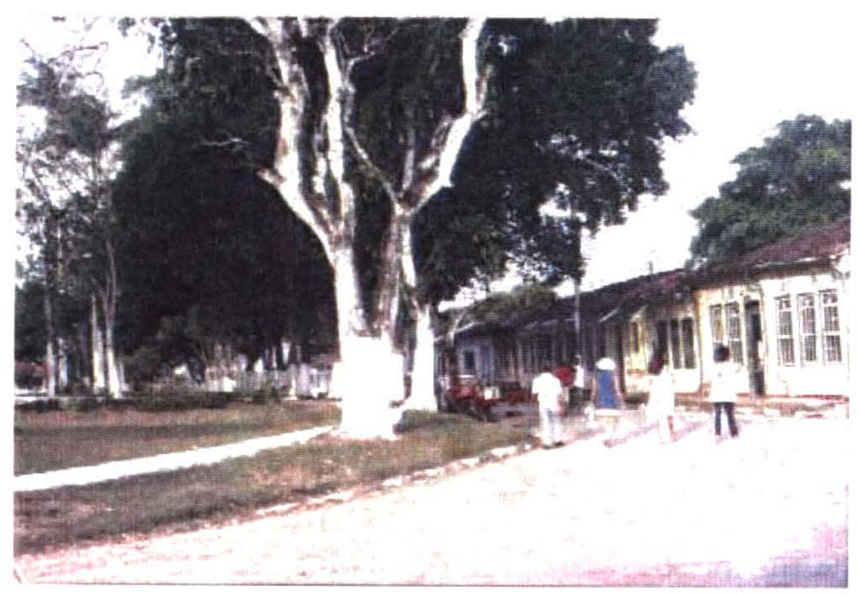

Figura 9 - Vista parcial do Arraial de São Francisco de Mombaça.

No Arraial de São Francisco da Mombaça vive uma população estimada de 850 pessoas. O acesso ao Arraial é feito pela rodovia estadual asfaltada BA-242 que liga Conceição do Almeida a São Felipe. A comunidade do Arraial é servida por uma escola pública municipal, que funciona em três turnos com 200 estudantes matriculados e, até dezembro de 2001, era servida também por uma creche. O serviço de água é fornecido pela Empresa Baiana de Águas e Saneamento S.A. 
(EMBASA); além deste serviço, a comunidade utiliza um chafariz público para o abastecimento de água. O tratamento e disposição dos esgotos sanitários é realizado com a utilização de fossa séptica e sumidouro (ACASFMombaça 2000). Inexistem, no local, serviços de correio e os telefones públicos foram instalados em 2002.

A economia local teve momentos de glória na década de 50 a 70 , quando a cultura do café e do fumo gerava um número grande de empregos no seu beneficiamento, o qual era realizado de forma artesanal. No entanto, nos anos 70 , auge desta produção, o beneficiamento passou a ser mecanizado e toda a produção foi retirada do município e transferida para a cidade de Conceição do Jacuípe e Cruz das Almas. Como conseqüência, veio o desemprego e a substituição da cultura do café e do fumo pela pecuária e as pequenas propriedades foram integradas às fazendas com maior extensão de terra, que demandam pouca mão de obra para o trabalho (ACASFMombaça 2001).

\subsubsection{Descrição do projeto desenvolvido no Arraial de São Francisco da Mombaça}

Selma Nascimento, farmacêutica bioquímica, depois de se aposentar como Professora da Universidade Federal da Bahia, começou a participar da Rede de Leitura - BA, comitê Salvador, que desenvolvia ações junto ao PROLER (Programa Nacional de Incentivo à Leitura). "O encontro com a leitura mudou minha vida" e a incentivou a conhecer melhor o Arraial de São Francisco da Mombaça, lugar em que viveram seus avós e onde costumava passar suas férias durante a infância e juventude. Atualmente, sua família possui uma propriedade rural e a antiga casa onde seus avós moraram, permanecendo, até hoje, uma forte ligação com o Arraial. Durante o ano de 1996, como resultado de conversas com as "vizinhas", foi se formando aos poucos uma "roda de conversas". "Desde o início, pela oralidade, criou-se o hábito de reflexão em rodas - conversas fiadas à sombra de uma jaqueira. Assim, através das Práticas Leitoras, as metas foram sendo traçadas para o projeto que se esboçava" (Relatório de Atividades: $2^{a}$ etapa, 1999). Entendem-se como Práticas Leitoras as atividades em torno da leitura e que, segundo YUNES (1994), 
tem como princípios pedagógicos a oralidade através de contação de histórias (estímulo à leitura através do resgate de histórias orais e da leitura em voz alta), leituras de textos e outras linguagens (música, vídeo, artes plásticas, dramatização, etc), seminários, entre outros, com o objetivo de incentivar a leitura, cujo papel é a formação da cidadania plena; "a capacidade de ler o contexto como texto, interagir com ele, refletindo e participando, qualifica os indivíduos para práticas sociais mais conscientes e valorizadoras de sua condição de cidadão. A leitura é uma atividade permanente na condição humana, quer se tenha ou não consciência dela. Lemos o mundo desde que nascemos e nossas ações decorrem desta leitura; a leitura tem, portanto, uma dimensão semiótica".

Da "roda de conversas", muitas lembranças do Arraial emergiram: as festas, as cantigas de roda, as brincadeiras junto à jaqueira da praça e também questões referentes à degradação ambiental, preocupação com o rio, com as fontes, com o desmatamento e com o lixo acumulado e exposto em vários locais (NASCIMENTO et al. 1998).

Paralelamente à "roda de conversas", algumas ações coletivas começaram a surgir, como o replantio de matas ciliares do Rio Pilão e, individualmente, com a assessoria de um técnico da Universidade do Estado da Bahia (UNEB), Selma iniciou a compostagem no fundo de seu quintal bem como a implantação de um biodigestor e um minhocário. "Oportuna foi esta experiência que se antecipou ao Projeto À Sombra de uma Jaqueira. Com essa experiência foram sendo introduzidos os princípios da coleta seletiva e a compostagem que passaram a ser práticas contínuas”, (Relatório de Atividades: $2^{2}$ etapa, 1999).

\subsubsection{Projeto Terra Viva - O que Queremos?}

...nós ousamos construir essas idéias, arrumá-las, organizá-las, criar um projeto, criar um programa Terra Viva - o que queremos, sempre há uma pergunta no fim de semana: o que queremos? Nós queremos uma terra viva, mas viva como? Nesse conceito de viva aparecia a palavra limpa, misturava, limpa de quê? Então, a gente teve que ralar um pouquinho para entender lum pouco dessas questões de vida, de morte, de 
adubo, de composto, de compostagem e tudo isso vira uma coisa que tem sentido: a morte, a vida e o renascer. Aí fomos construindo esse projeto...(depoimento da coordenadora do projeto)

O primeiro projeto foi denominado "Projeto Terra Viva - O que Queremos?" e foi realizado com a assessoria voluntária de integrantes da Rede de Leitura/BA, comitê Salvador, apoiando, principalmente, a capacitação de recursos humanos. O projeto foi desenvolvido durante o período de agosto de 1996 a abril de 1997 e teve como objetivo responder àquelas preocupações que emergiram durante a "roda de conversas". O projeto "Terra Viva - o que queremos?" foi enquadrado na temática Educação Ambiental definida como "atividade eminentemente empírica que busca a conscientização do que está em volta do homem, na sua casa, na escola, no trabalho, no lazer: do que se é, onde se está, por quê e para quê. Ela surge como uma proposta pedagógica de libertação das rotinas tradicionais, apontando para a preocupação de se incentivar uma política de conservação ambiental através de projetos educacionais dentro e fora da escola". A proposta foi de estabelecer um vínculo entre escola, arraial e moradores para a formação de nova mentalidade no sentido do cidadão fazer uma leitura crítica de sua comunidade e reconhecer o Arraial enquanto valor patrimonial, cultural e enquanto espaço de vida. Para o embasamento das práticas a serem desenvolvidas, articularam-se parcerias com a Rede de Leitura/BA, comitê Salvador, com a UNEB/Santo Antônio de Jesus e com a Equipe de Educação Ambiental da UEFS.

O público alvo constituiu-se de alunos, professores e pais de alunos da Escola Rural Nicolau Coni, localizada no Arraial e da comunidade local como um todo. Para atender aos objetivos propostos: propiciar à comunidade condições para a compreensão da importância da leitura como instrumento fundamental ao exercício da cidadania, e desenvolver o pensamento crítico diante de um olhar mais apurado na região, como também identificar os problemas ambientais locais. Para isso, utilizaram-se atividades desenvolvidas nas oficinas de Práticas Leitoras. Nesse período, foram proporcionadas à comunidade, aos professores e aos alunos da escola local visitas à sede da Equipe de Educação Ambiental da UEFS e ao Projeto Verde Vale da UNEB, em Santo Antônio de Jesus. Essas visitas tiveram como objetivo 
mostrar à comunidade experiências sobre o manejo do lixo urbano e sobre o plantio de matas ciliares, respectivamente.

Durante esse processo, emergiu, de um grupo da comunidade, a decisão de dar continuidade aos encontros de leitura, passando esse grupo a reunir-se periodicamente.

Para sistematizar melhor as ações e para concretizar soluções para as demandas apresentadas, um novo projeto foi escrito e submetido à aprovação da Fundação ABRINQ a fim de obter recursos financeiros e possibilitar a continuidade das atividades despertadas na comunidade. O projeto teve como título "À Sombra de uma Jaqueira. Projeto - Escola/Comunidade Rural/Cidadania”. A escola local sediou tal projeto, considerando-se que trabalhar com escolas era uma das condições de elegibilidade para a aprovação do projeto.

\subsubsection{2 À Sombra de uma jaqueira. Projeto - Escola/Comunidade Rural/Cidadania"}

Esse projeto foi desenvolvido durante o período de agosto de 1997 à julho de 1998. Para entender o processo que culminou com a escrita do Projeto À Sombra de uma Jaqueira, transcreve-se abaixo a visão de sua coordenadora, obtida da entrevista realizada com ela em abril de 2002.

"Começamos a notar que a natureza "sentia" e resolvemos verificar isso, saber o porquê disto, quais eram suas origens. Daí, começou um trabalho que a gente chama hoje de projeto, que acabou ficando com o nome de "projeto". Outros trabalhos aconteceram e vêm acontecendo, mas ficou marcado com o nome de "projeto". Na medida em que as pessoas da comunidade começaram a se interessar pela idéia, começaram as lembranças de como eram os prazeres de antigamente. Começamos a levantar alguns escritos, as pessoas escreviam e me entregavam, eu lia, arrumava. Começanos a ver também a questão das mudanças de hábito, dos costumes e da própria natureza, porque a fonte do Birreiro é uma bica "de nada", a tal da fonte a que se referiam tinha histórias, tinha lembranças. Então, nós começamos a ligar que havia uma ação danosa do homem e começamos a procurar entender um pouquinho sobre isso e, nesse processo, acabaram rolando umas visitas 
que um grupo da comunidade começou a fazer em centros de referências de estudos do meio ambiente e dessa questão da Educação Ambiental. Fizemos uma primeira visita ao Centro de Educação Ambiental da UEFS e lá fomos muito bem recebidos e, até hoje, mantemos essa relação e com isto também, a gente começou a se deslumbrar com um saber novo. Tivemos, também um contato com a UNEB de Santo Antônio de Jesus. Naquela época, o professor Rubens desenvolvia um projeto que era de replantio de matas ciliares, o Projeto Verde Vale. Nós nunca tínhamos ouvido falar nesse nome, matas ciliares e, aí, começamos a despertar para isso, e o despertar significou uma ação, uma prática. Voltamos para Mombaça pensando até que ponto poderíanos cuidar melhor do Rio dos Pilóes. Rio dos Pilóes que, durante certos períodos no verão, começava a secar, não ter água; não passava água, daí deixava de ser rio e a gente via as pedras no fundo do riacho. Então, começamos a pensar numa ação de plantar coisas da região mesmo, árvores que começaram a ser sacrificadas durante muito tempo, a Jaqueira é uma delas. Assim, começamos a fazer o replantio na beira do Rio dos Pilóes. Ficamos sabendo além, não só o que era mata ciliar, mas também participando dessa recomposição, desse replantio e pensando em ampliar isto, em ações que foram descobertas. Começamos a compreender melhor essa questão: porque a fonte do Birreiro não existia mais como era antigamente? Vimos que o que existia de sombra deixou de existir, o que existia de proteção deixou de existir, então, o papo mudou. Quer dizer, aquelas mulheres não tinham mais o mesmo prazer de ir para a fonte do Birreiro lavar sua roupa $e$ ficar ali, transformando aquele dia num programa, um programa gostoso. Então são lembranças prazerosas que elas tinham e se referiam desse jeito. Ao lado disso, com a UEFS, na EEA, a gente viu, pela primeira vez, a prática da reciclagem do papel artesanal, depois tivemos uma visita do grupo da UEFS até Mombaça e, então, o pessoal começou a fazer isto. Foram atos novos, novas culturas que foram sendo introduzidas nessa idéia do "Projeto à Sombra de uma Jaqueira" que começamos a desenvolver. Mas, para isto, para chegar ao projeto "À Sombra de uma Jaqueira", passamos por todas as conversas que antecederam essas lembranças e essas lembranças foram subsídios para a construção dos trabalhos".

Então, lembrar de um marceneiro fantástico que tinha na Mombaça, o marceneiro chamava Tecou. Ele fazia coisas lindas, até hoje ninguém se esquece da 
figura de Tecou e das coisas que ainda existem lá na casa grande, móveis feitos por ele. Então o "Projeto À Sombra de uma Jaqueira" foi se construindo diante dessas memórias, dessas lembranças e dessa falta, dessa ausência que eu acho fundamental. Foi nessa ausência que o projeto se inspirou, em cima da ausência que veio alimentar todos esses desejos de uma transformação. E coisas outras também, que eram conhecidas, como o gosto, a comida, o sabor das comidinhas gostosas da cozinha das pessoas, isso também foram coisas relembradas e o projeto tentou tocar nesses pontos, sem falar na própria cultura, na arte e na mísica" (Coordenadora do projeto).

\section{Objetivo e atividades do Projeto À Sombra de uma Jaqueira.}

O objetivo do projeto foi:

"Realizar oficinas de práticas leitoras, visando à formação do leitor e do sercidadão na criança, dentro da escola, numa constante interação com a comunidade e a partir desta experiência, gerar um agente multiplicador do processo de enriquecimento escolar, na região".

Para atingir o objetivo proposto, foram programadas e realizadas oficinas de ambiência de leitura, reciclagem de papel, compostagem, construção de brinquedos, musicalização, confecção de roupas e de bonecas, com também oficinas de expressão corporal. Todas elas tiveram como base reflexiva a utilização de textos escritos, servindo para despertar a criação da linguagem específica. Foram realizadas oficinas com alunos, professores e a comunidade, envolvidos no universo da escola local.

Além dos parceiros conquistados no Projeto Terra Viva, outros foram incorporados. Para a gestão dos recursos financeiros, o parceiro foi a Associação de Desenvolvimento Comunitário do Povoado de Pau Cedro. A Prefeitura Municipal de Conceição do Almeida apoiou com transporte e alimentação dos oficineiros.

Após o término de cada atividade, procedia-se à avaliação entre professores e alunos (na sala de aula); o professor avaliando-se na escola, através de questionários, desenhos ou através da escrita de uma carta endereçada a um amigo onde deveria relatar suas impressões sobre o vivenciado no dia; entre professores, representantes 
da comunidade, oficineiros e membros da coordenação, através da oralidade e reflexões.

\section{Resultados}

Alguns resultados obtidos, conforme descritos nos Relatórios de Atividades da $1^{\mathrm{a}}$ e da $2^{\mathrm{a}}$ etapa, foram:

- Valorização e preservação de "acervos" da natureza, pessoal e social tais como tradição, histórias, festas, música da comunidade local.

- Criação do coral Terra Viva com encontros sistemáticos para a construção de repertórios.

- Irradiação das oficinas de reciclagem de papel e brinquedos para outros locais.

- Participação do coral em festejos nas comunidades vizinhas.

- Envolvimento do grupo local nos encontros de avaliação e planejamento do projeto, bem como em Encontros e Feiras de Saúde.

- Preservação da cultura de trabalhos manuais onde antigas costureiras (bordadeiras) relembram e repassam seus pontos para as crianças.

- Criação da Associação Comunitária do Arraial de São Francisco da Mombaça ACASFMombaça, em 14 de fevereiro de 1998.

- Criação de oportunidades de geração de renda, sendo viabilizado curso de Fabricação de Doces e Processamento de Vegetais e de Leite com apoio do Serviço Nacional de Aprendizagem Rural (SENAR).

- A presença do grupo local em Feiras de Saúde despertou nos agentes comunitários de saúde da região, interesse pelo aprendizado

- ACASFMombaça recorre ao Curso de Engenharia de Alimentos do Departamento de Tecnologia da UEFS, assessoria técnica para aperfeiçoamento na produção e comercialização de doces e à EEA/UEFS para resolver a problemática do lixo local.

A figura 10 ilustra parte desses resultados obtidos com o projeto. 
$\mathbf{A}$

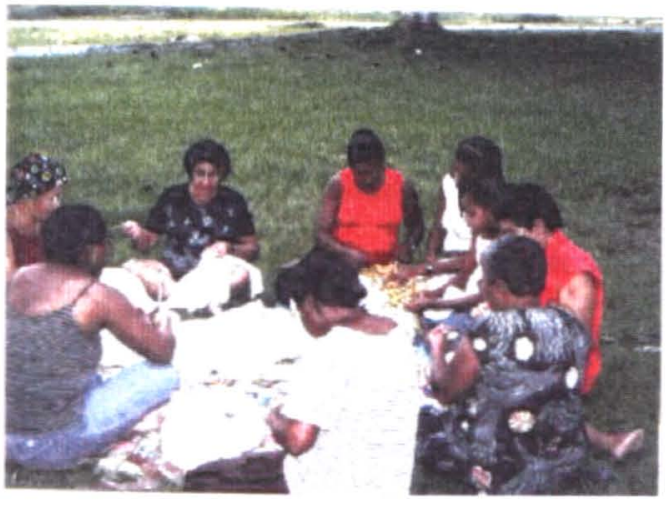

C

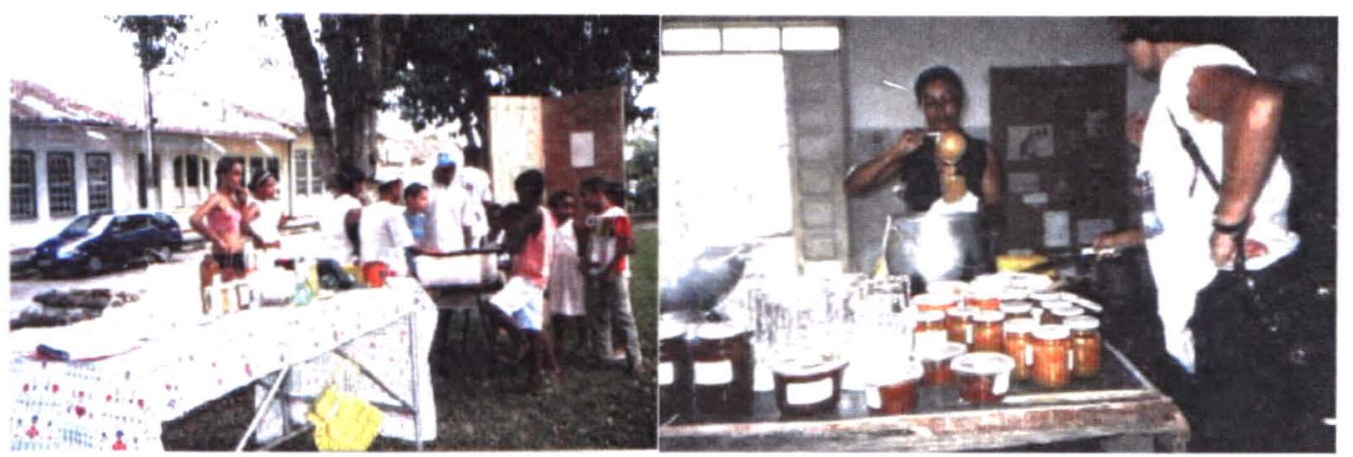

B

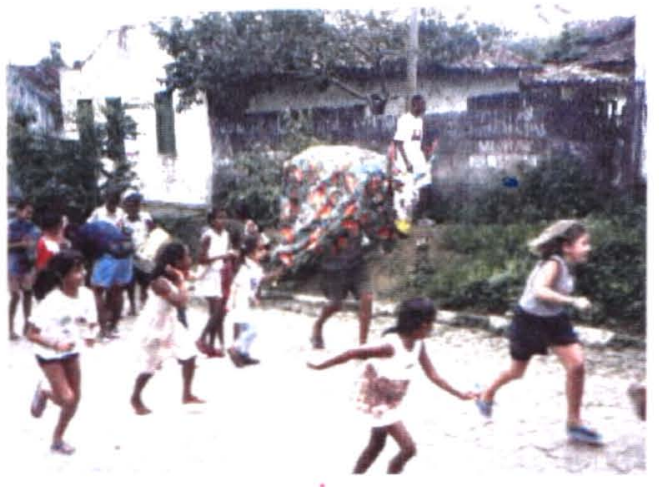

D

Figura 10 - Resultados do projeto desenvolvido no Arraial de São Francisco da Mombaça. (A) Roda de Bordado; (B) Resgate da Cultura Local (bumba-meu-boi);

(C) Materiais produzidos em oficinas de papel e de brinquedos de sucata; (D) Fabricação de doces caseiros "Sabores da Terra".

\subsubsection{O lixo no Arraial}

"Às onze horas, numa noite enluarada de verão, me lembro - eu e Selma sentadas no banquinho, na praça da igreja, aqui no Arraial da Mombaça, em conversa, buscando o fio de uma meada para costurar lembranças passadas; de repente, um clarão, chamou a nossa atenção. Juntas, fomos ver o que estava acontecendo e, no local, adiante, vimos um monte de lixo sendo queimado. A fumaça saia preta e se espalhava no ar. Acompanhamos com os olhos e lamentamos com a consciência, o mal que aquela fumaça poderia causar às pessoas que estavam dormindo $e$ 
respirando aquela fumaça, com aquele odor desagradável. Voltamos, cada uma foi para sua casa, levando uma inquietação.

Na manhã seguinte, com uma máquina, fomos fotografar o local. Encontramos restos de lixo de todo o tipo. Falamos uma para a outra - temos que buscar uma saída...." (Anatólia, pessoa da comunidade).

O serviço de coleta de lixo da Prefeitura de Conceição do Almeida não atendia satisfatoriamente o Arraial de São Francisco da Mombaça. A coleta do lixo não era realizada porta a porta, sendo comum ser executada em intervalos superiores a 15 dias. Com isso a comunidade, buscando uma alternativa para a ineficiência da coleta, depositava seu lixo em terrenos baldios. O principal ponto de descarte de lixo do Arraial era um terreno em frente à escola municipal e ao lado do salão paroquial. Muitos moradores sentiam-se incomodados com a situação e, com o desenvolvimento dos projetos, a vontade de resolver esse problema emergiu inúmeras vezes. Para ajudá-los na resolução da questão, a ACASFMombaça propôs uma parceria com a EEA/UEFS no sentido de realizar um trabalho de Educação Ambiental para resolução do problema do lixo no Arraial.

Em reuniões com a comunidade, observou-se que apenas exigir do poder público a frequiência da coleta não seria suficiente para a solução da questão da destinação adequada do lixo na localidade. Isto porque o manejo do lixo da cidade de Conceição do Almeida, naquela época, também era inadequado, coletado e disposto a céu aberto em local não confinado e visível para os moradores da Mombaça quando se deslocavam para a sede do município. Por outro lado, muito dos moradores de Mombaça haviam incorporado a importância da compostagem e do uso do composto em seus quintais. Outro fator que ajudou a definir o gerenciamento do lixo foi o anseio da ACASFMombaça de possuir uma sede própria, tendo a Prefeitura sinalizado a possibilidade de adquirir um terreno para esse fim.

A idéia era que nesse terreno fosse construída a sede da ACASFMombaça que abrigaria uma oficina artesanal de papel e embalagens e uma cozinha para a fabricação de doces com as frutas da região. $O$ terreno teria, também, uma estrutura para receber o lixo coletado seletivamente e com mercado na região. A fração 
orgânica proveniente da coleta na comunidade e da cozinha industrial sofreria o processo de compostagem. O restante dos resíduos que não pudesse ser reaproveitado seria depositado em um aterro manual, preparado no terreno. $\mathrm{O}$ composto produzido seria utilizado como insumo em uma sementeira para produção de mudas de plantas nativas para recomposição de matas ciliares, plantio de árvores frutíferas e uma horta comunitária com plantas medicinais e comestíveis sediada no próprio terreno da Associação, tendo-se com essas atividades a possibilidade de geração de emprego e renda para a comunidade local.

Com esta concepção, foram realizados estudos técnicos para avaliação de dois terrenos pré-selecionados, bem como foi executada a caracterização do lixo produzido no Arraial.

Para realizar a caracterização quantitativa do lixo, os jovens do Coral Terra Viva levantaram os pontos de lixo existentes no Arraial e confeccionaram um mapa contendo o arruamento e a identificação dos imóveis, tornando possível traçar o plano de amostragem para as duas caracterizações que foram feitas em dois dias diferentes (19/03/1999, Sexta-feira e 10/04/1999, Sábado). O plano contemplou a sensibilização dos moradores, a forma da coleta e a pesagem.

Para o sucesso do trabalho de caracterização física dos resíduos sólidos, era necessária a participação dos moradores na segregação do lixo e na sua apresentação para a coleta de forma separada. Inicialmente, foi distribuída uma carta aberta em todos os domicílios, a qual continha as instruções para separação do lixo nos dias estabelecidos para a amostragem. Para cada domicílio, foram doados dois sacos plásticos: um deveria conter o lixo úmido (resíduo orgânico, papel engordurado) e no outro saco, o lixo seco (plástico, papel, metal, papel e vidro). Os sacos foram distribuídos no dia anterior à amostragem juntamente com a carta que explicava o objetivo do trabalho e a forma de separação. Esta tarefa ficou a cargo de integrantes da Associação, contando com o apoio da Prefeitura Municipal de Conceição do Almeida. Para a divulgação, utilizou-se também um carro de som nos dias que antecederam à coleta.

A coleta foi realizada por um trator com caçamba aberta acoplada. Foram recolhidos os sacos dispostos na calçada, em frente às residências. De forma aleatória, foram marcados os sacos para a amostragem, que deveriam totalizar $100 \mathrm{~kg}$ 
aproximadamente. Os geradores desse lixo foram entrevistados a fim de se obter o número de residentes no domicílio e também dados sobre a percepção das pessoas em relação à questão do lixo. A coleta foi acompanhada por alunos da escola local e por membros da Associação.

A pesagens foram realizadas em locais públicos, sendo a primeira caracterização realizada em frente à escola e a segunda, na praça principal do Arraial.

A figura 11 ilustra a atividade de caracterização dos resíduos sólidos no Arraial e o resultado da caracterização encontra-se na tabela 8 .

A

B

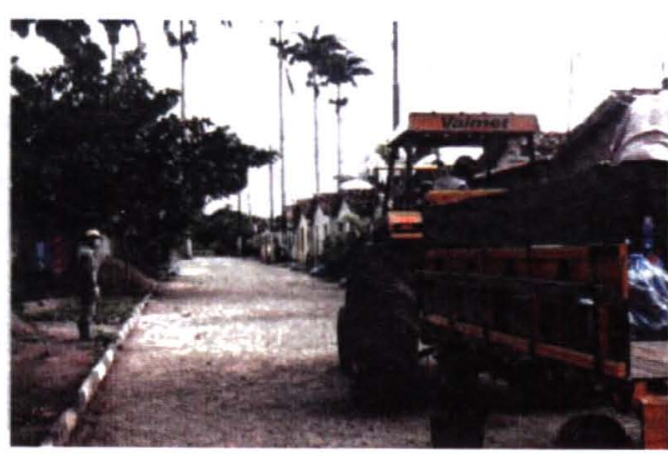

C

D

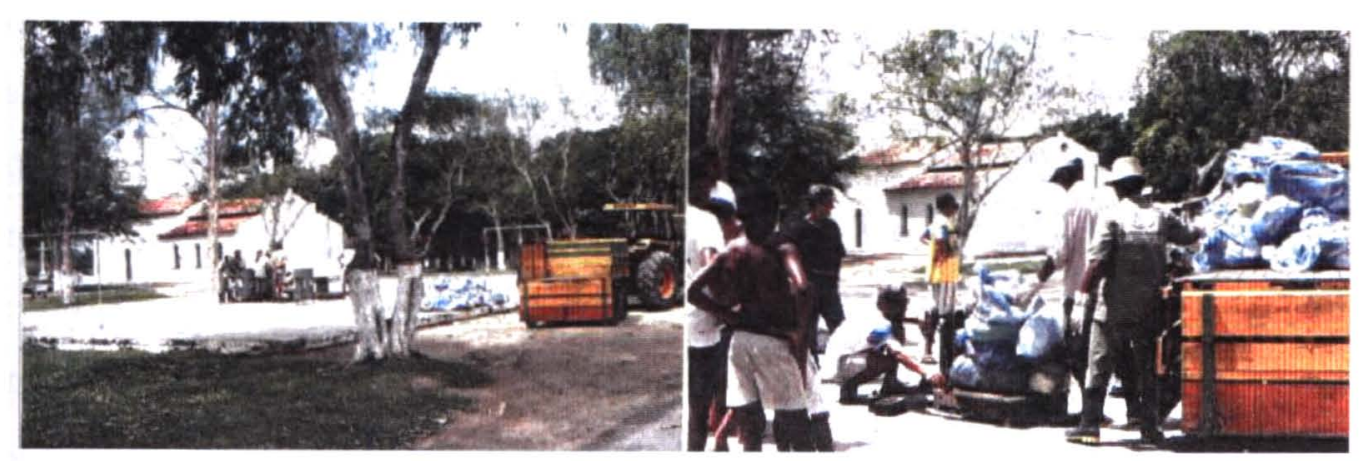

Figura 11 - Caracterização do lixo gerado no Arraial de São Francisco da Mombaça (A) e (B) Coleta do lixo segregado; (C) Lixo coletado para a caracterização; (D) Pesagem do lixo. 
Tabela 8 - Composição gravimétrica do lixo produzido no Arraial de São Francisco da Mombaça, segundo duas caracterizações realizadas.

\begin{tabular}{|c|c|c|c|}
\hline \multirow[t]{2}{*}{ Componentes } & $\begin{array}{r}1^{\mathrm{a}} \text { Caracterização } \\
19 / 03 / 1999\end{array}$ & $\begin{array}{c}2^{\mathfrak{a}} \text { Caracterização } \\
10 / 04 / 1999\end{array}$ & \multirow[t]{2}{*}{$\begin{array}{c}\text { Média } \\
(\%)\end{array}$} \\
\hline & $\%$ & $\%$ & \\
\hline Orgânico & 76,1 & 68,4 & 72,2 \\
\hline Plástico & 8,1 & 8,1 & 8,1 \\
\hline Ferroso & 2,7 & 4,9 & 3,8 \\
\hline Não Ferroso & 0,1 & 0,1 & 0,1 \\
\hline Pano, borracha, madeira & 5,2 & 3,2 & 4,2 \\
\hline Papel/Papelão & 3,2 & 4,5 & 3,9 \\
\hline Vidro & 2,3 & 9,7 & 6,0 \\
\hline Inerte & 2,3 & 1,1 & 1,7 \\
\hline TOTAL & 100,0 & 100,0 & 100,0 \\
\hline
\end{tabular}

Fonte: DIAS et al. 2000

Como resultado da entrevista com os moradores, verificou-se que a maioria deles separara o lixo nos dias solicitados, conforme instruções contidas na carta aberta e não achou difícil esta separação. Perguntados sobre a coleta seletiva, $64 \%$ dos entrevistados responderam que separariam o lixo caso fosse implantado rotineiramente o sistema; $18 \%$ acharam trabalhosa a separação; e $18 \%$ não compreenderam a forma de separação. Algumas pessoas não colocaram o lixo na porta, justificando que não produziram lixo, não entenderam o processo de separação, acharam mais fácil jogar no ponto de lixo próximo e até mesmo porque utilizaram o saco para armazenar seus utensílios domésticos (DIAS et al. 2000).

Quanto ao destino dado ao lixo pelos moradores de Mombaça, a maioria (63\%) pratica a queima ao ar livre, $6 \%$ depositam em seu quintal e $31 \%$ levam até os pontos clandestinos de deposição do lixo.

O laudo técnico sobre os dois terrenos pré-selecionados concluiu que ambos poderiam ser utilizados para a implantação do aterro manual e da usina de compostagem. O relatório com os dados levantados foi encaminhado à Prefeitura de Conceição do Almeida para os devidos direcionamentos. 
Esta primeira concepção de gerenciamento foi, posteriormente, abandonada em função da falta de empenho do poder público na aquisição do terreno para implantar a usina de compostagem e a sede da ACASFMombaça, agravado pelo fato de ambos os locais estarem com problemas na documentação.

\section{Segunda proposta para o gerenciamento do lixo}

“Estamos com um problema muito sério, que é o lixo. O lixo está sendo depositado no lugar onde não é adequado, em frente da escola. Estanos com o plano de fazer um jardim no lugar onde o lixo se encontra." (Josué, componente do coral, morador do Arraial, Relatório de Atividade $2^{\mathrm{a}}$ etapa)

Diversos setores da comunidade do Arraial, a exemplo de integrantes da ACASFMombaça, da Escola e do Coral Terra Viva, continuavam incomodados com o lixo depositado a céu aberto em vários pontos da localidade e estavam dispostos a agir de forma a proporcionar um manejo adequado dos resíduos. Já havia surgido a idéia de transformar os pontos de depósito de lixo em praças, contudo questionavase: o que fazer com o lixo? A partir daquela idéia, e buscando responder a esse questionamento, os integrantes do projeto propuseram a um grupo de jovens do Arraial, a discussão dessa questão. Durante as oficinas de "Práticas Leitoras", os jovens idealizaram a praça, a qual foi expressa em imagens e desenhos. O resultado das oficinas foi a concepção e a implantação da praça e a permanência do lixo no mesmo local, de forma organizada.

Com a proposta esboçada, coube à EEA/UEFS a construção de uma maquete contendo alguns equipamentos, inclusive as baias de armazenamento do lixo, para ser trabalhada com o grupo e com os alunos da Escola. Também foi elaborado um texto pela EEA para ser discutido e ilustrado pelos participantes em oficinas, denominadas de "Sonhar com Dias Melhores". Este trabalho teve, como produto, uma cartilha de divulgação sobre a forma de recebimento do lixo na praça. Os meninos do coral e os monitores do Projeto foram responsáveis pela divulgação da proposta junto aos usuários daquele ponto de lixo e pela construção das baias de 
bambu para o recebimento do lixo, as quais foram dimensionadas a partir da realização da caracterização do lixo, determinando-se o intervalo de coleta do lixo encaminhado à praça, de 15 em 15 dias.

O processo idealizado para solucionar o descarte do lixo foi o de incentivar os moradores a levarem seus resíduos até o local, de forma separada: orgânico e seco. $\mathrm{O}$ material orgânico deveria ser descartado em uma composteira coletiva e o seco em uma baia, ambas construídas no terreno. Também foram realizados programas educacionais para incentivar práticas de minimização de resíduos no próprio domicílio, a exemplo da compostagem doméstica, já utilizada por muitos moradores. Como o lixo ficou confinado em pequeno espaço, foi utilizado o restante do terreno para a implantação de uma praça planejada e implementada pelas pessoas da própria comunidade (Figura 12).

A

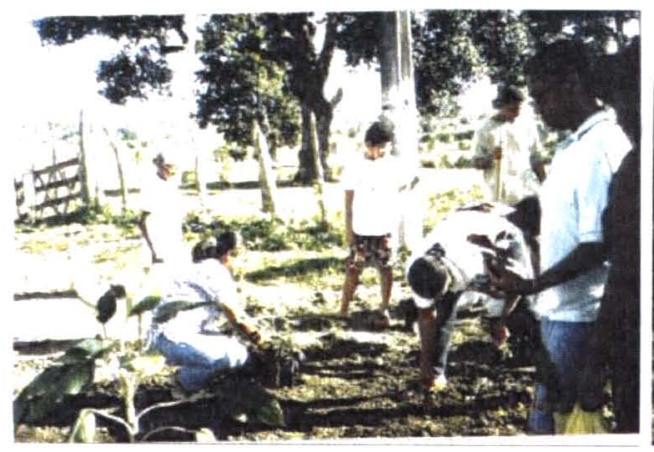

C

$\mathbf{B}$
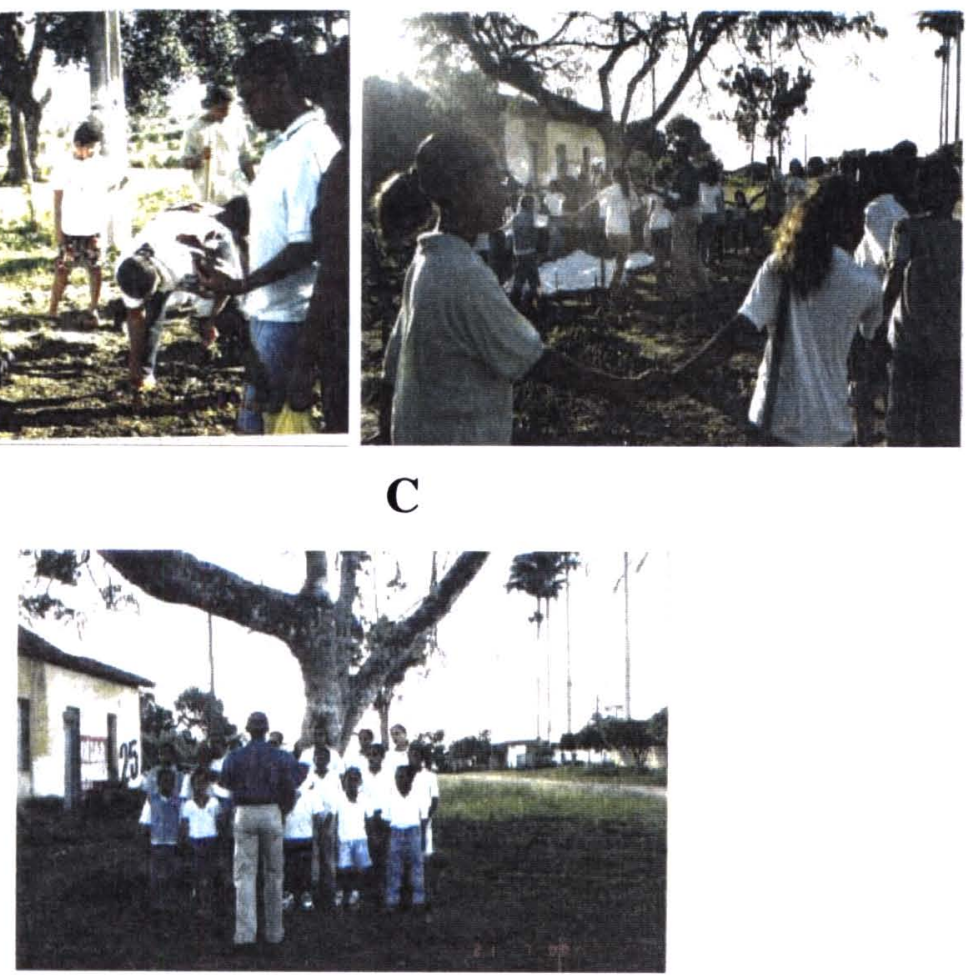

Figura 12 - Implementação da Praça Terra Viva: (A) Plantação das mudas de plantas pela comunidade; (B) Abraçando a Praça; (C) Apresentação do Coral Terra Viva.

Para a implementação da praça, foi realizada a preparação do terreno pelo serviço de limpeza municipal de Conceição do Almeida juntamente com a 
comunidade. Em junho de 2000, foi, oficialmente, implantada a "Praça Terra Viva", através do plantio das mudas que foram cedidas pela Prefeitura Municipal de Conceição do Almeida e pela UEFS, como também de mudas retiradas dos quintais dos próprios moradores da comunidade. A Figura 13 ilustra o terreno antes e depois da implementação da praça.

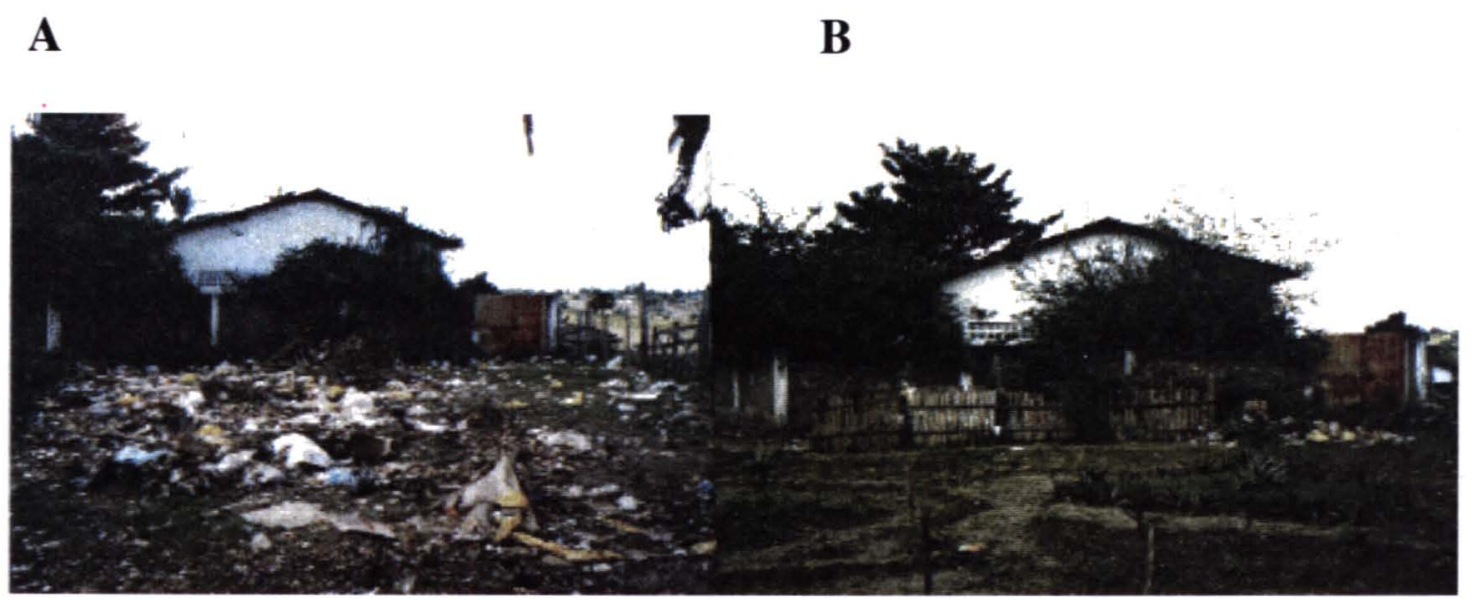

Figura 13 - (A) Vista do terreno com o lixo; (B) Praça implementada, vendose ao fundo as baias de armazenamento do lixo.

O manejo do lixo, proposto, funcionou satisfatoriamente por parte dos usuários pois eles já tinham o hábito de deslocar-se até o local para a disposição dos resíduos e se propuseram a trazê-los de forma separada.

TRAJBER E MANZOCHI (1996 p 33) observam que as soluções para os problemas ambientais não se constituem em receitas simples. Elas precisam passar pela reflexão individual, a incorporação de mudanças de visão de mundo e de comportamento em seu cotidiano, pela organização da sociedade por meio da participação da comunidade e pela articulação desta com o Poder Público. Foi este último ponto o elo fraco observado no Arraial de São Francisco da Mombaça.

Embora a ACASFMombaça procurasse sempre buscar a articulação com a Prefeitura de Conceição do Almeida, isto não aconteceu de forma satisfatória. Duas falhas ocorreram por parte do poder público: a primeira foi o de não fazer a sua parte no processo de gerenciamento do lixo, proposto (coletar o lixo de $15 \mathrm{em} 15$ dias) e a 
outra, deve-se ao modelo político observado em muitas prefeituras do interior da Bahia que, em período de eleição e na troca da administração, dificultam a continuidade de projetos comunitários. Dentro do manejo proposto e aceito pela Prefeitura Municipal, estava o compromisso de coletar o lixo seco com freqüência quinzenal e de forma manual. Ocorreu que a freqüência de coleta não teve essa regularidade, permanecendo o lixo por mais de trinta dias depositado, ocasionando o seu transbordamento. Para a coleta, a Prefeitura utilizava uma máquina retroescavadeira que, além do lixo, levava junto as baias construídas com bambu, sendo necessária sua reconstrução após cada coleta municipal. Não houve a designação de um funcionário contratado pelo município para trabalhar no local, tanto para a conservação do espaço, como para a manipulação, de forma adequada, do material proveniente da poda, sendo que este papel foi exercido, muitas vezes, pela comunidade.

“....se pudesse haver um encontro entre essa iniciativa do projeto e o governo do município e que este compreendesse esse investimento privilegiado que o povoado está apresentando, dando um pouco da sua contribuição, mesmo pequena, o projeto daria um salto muito grande, pois seria a soma. o ideal é isto, que o projeto não estivesse ocupando espaço do governo, ocupando espaço de atuaçâo de selıs governantes, mas, sim, que estejamos contribuindo, estejamos ali como base, como pessoas pensantes e que estão recebendo aquilo que estão demandando e, não, recebendo porque o outro está querendo dar. Há uma diferença muito grande nisto." (Coordenadora do projeto)

A comunidade não desistiu e continua firme no propósito da resolução da questão de seu lixo através de novas articulações com a atual administração do município. Atualmente, a Prefeitura do município de Conceição do Almeida está coletando o lixo duas vezes por semana, contudo, observa-se no discurso de muitos membros da comunidade, que esta não é a forma que eles desejariam para o manejo do lixo do Arraial. A praça continua recebendo o lixo de forma inadequada, depositado onde foram construídas as baias, e os integrantes da Associação fizeram um novo projeto para o local, o qual já foi encaminhado à Prefeitura Municipal. 


\subsubsection{O Discurso do Sujeito Coletivo}

A grande maioria dos entrevistados gosta de morar no Arraial de São Francisco da Mombaça por ser um lugar calmo e sem violência.

"Se é uma coisa que eu adoro é verde, é trabalhar na roça. Mombaça faz parte da minha vida, eu não consigo, acho que não consigo viver em outro lugar assim, para ter a mesma liberdade, viver ao ar livre, a mesma alegria que eu tenho. Cada pedacinho aqui da Mombaça faz parte de mim. Para mim, eu acho que não tem lugar igual para morar, a gente sai correndo o mundo; vai num lugar e vai no outro, mas Mombaça para mim é um dos melhores lugares que existem. Eu gosto daqui porque não é violento, é calmo, é bom de morar".

Pessoas relataram que, em Mombaça, não existe oportunidade de emprego e, por isto, não gostam do lugar.

"Eu não gosto daqui, eu não gosto. É um lugar muito parado. Eu gosto de trabalhar, esse negócio de ficar parado não dá, não. A pessoa tem sua profissão, não pode exercer nenhuma porque aqui não tem como fazer mesmo, aí, pronto, eu não gosto. Aqui é um lugar calmo para se viver, mas negócio de trabalho não tem nada. O problema todo é esse, o trabalho. É o filho que não pode trabalhar fora, aqui também não acha trabalho, o meu filho mais velho chegou, isso tudo esquenta minha cabeça".

A seguir, são apresentados os discursos dos sujeitos coletivos (DSC) referentes a cada idéia central. No anexo 2 são relacionadas às expressões-chave referente a cada idéia central expressa pelos diferentes sujeitos.

\subsubsection{Discurso do sujeito coletivo sobre o projeto.}

Foi perguntado aos moradores do Arraial: o que você sabe sobre o projeto de Educação Ambiental realizado em Mombaça? Fale-me sobre ele. As respostas obtidas permitiram que os discursos fossem construídos de forma que todo o processo de desenvolvimento do projeto fosse descrito em uma seqüência lógica. Essa seqüência constituiu-se das idéias centrais para a composição dos discursos do 
sujeito coletivo, a saber: sentimento sobre o projeto, como ele surgiu, as atividades realizadas, o que o projeto proporcionou a Mombaça, o projeto na escola e as frustrações sentidas pelos sujeitos. Também se obteve o discurso cuja idéia central foi o desconhecimento do projeto.

\section{Idéia Central: Sentimento sobre o projeto}

\section{DSC 1}

No início,' esse projeto foi como uma bomba, foi uma coisa de que eu jamais esperava que fosse participar e com que pudesse me relacionar, conhecer pessoas novas e descobrir coisas novas ${ }^{51}$. Ele foi um acontecimento que chegou aqui aos poucos, foi se alojando e foi tomando conta da gente, da imaginação da gente, da vida, das noites de sono. Para mim esse projeto desenvolvido aqui é como o primeiro namorado que a gente vê e aí bate aquela coisa forte dentro da gente, mas sem explicação. Então, o projeto, para mim, foi isso, ele começou e eu não estava entendendo direito o que era. Aos poucos, eu fui conhecendo, fui vivendo, participando, falando sobre tudo isso, e cada vez mais, ele ia tomando um lugar dentro de mim, da minha consciência e foi se desenvolvendo e foi ficando cada vez mais bonito, o entusiasmo foi crescendo, a vontade de desenvolver e de ver as coisa acontecerem $^{S 3}$. Eu aprendi muito com esse projeto. Esse projeto veio a calhar na vida de muita gente ${ }^{S 1}$, veio enriquecer a Mombaça, veio dar uma experiência a mais para a gente ${ }^{59}$, até a forma de se relacionar com as pessoas, que é uma coisa que a gente tem sempre pavor ${ }^{S 1}$, porque hoje eu sei muita coisa através do projeto inclusive sobre o lixo, e hoje a gente tá conseguindo se relacionar até com ele ${ }^{S 1}$.

Para mim, é uma coisa boa, é uma coisa de que eu gosto, me interessa e que eu gostaria de ver continuar andando ${ }^{\text {sII. }}$.

\section{Idéia Central: $\mathbf{O}$ início do projeto}

\section{DSC 2}

O projeto de Educação Ambiental começou quando as pessoas foram ao rio e quando lá chegaram, viram que estava tudo secando. Aí D. Selma começou a 
conversar, então é mesmo? Vamos embora descer para ver. E aí, com isso, ela desceu com a turma para olhar ${ }^{S 2}$. Então, o projeto de Educação Ambiental, pelo que eu me lembro, surgiu até antes do Projeto À Sombra de uma Jaqueira. D. Selma começou a falar na questão ambiental daqui do Arraial, onde quando se aproximou, também, da UNEB, em Santo Antônio de Jesus através do professor Rubens ${ }^{S 4}$. A partir daí surgiu o Projeto À Sombra de uma Jaqueira" e junto com esse projeto surgiu o projeto Terra Viva. Terra Viva: O Que Queremos?, que era o título desse projeto de Educação Ambiental.

Tinha também o lixo, que era horrivel, ali na frente da escola ${ }^{S 2}$. O projeto, ele começou com a inquietação do pessoal sobre esse amontoado de lixo, o cheiro que causava mal quando a gente passava, ele ia se arrastando. A coleta não era feita no tempo devido, crianças no meio brincando, catando coisas e não tinha aquele cuidado de lavar as mãos e muitas pessoas queixando, falando que o cheiro era desagradável $^{\text {s8 }}$. Já veio outra preocupação, a gente vai ter que dar providência nesse lixo. Então, com o Projeto À Sombra de uma Jaqueira, abriu-se uma linha para atender toda essa preocupação da comunidade e da escola e resolveu-se, em vez de fazer um trabalho só com práticas leitoras, a gente saiu da escola para a comunidade $^{s 9}$.

\section{Idéia Central: Atividades realizadas}

\section{DSC 3}

Quando começou o inverno, o professor Rubens, da UNEB, mandou mudas e aí começou aquela empolgação, todo mundo, crianças, velhos, jovens, todo mundo a descer para fazer o replantio. Plantou também na fonte, porque ele deixou bem claro, se a fonte não tiver árvores, ela seca ${ }^{s 2}$. E nisso começaram a aparecer pessoas falando sobre a questão ambiental, dando palestras $e$ a gente começou a enxergar esse outro lado. Além de fazer o plantio de matas ciliares, começou a ver também as experiências de outros profissionais na área de Educação Ambiental ${ }^{\text {S3 }}$. A gente saiu daqui para outros lugares, para conhecer as áreas ambientais como o DDF de Santo Antonio de Jesus e o Projeto Verde Vale, da UNEB que mostrou 
alguns vídeos de meio ambiente. Foram três professores daqui para tomar esse curso de Educação Ambiental juntamente com o pessoal da UNEB ${ }^{S 3}$.

Depois disto, começamos a discutir a questão do lixo da frente da escola, que era uma coisa que estava incomodando e a gente não sabia a solução ${ }^{\text {s4 }}$. Selma, também como coordenadora do projeto, foi até Feira para ver como é que se fazia o trabalho lá, eu fui junto para ver como eles trabalhavam e daí, vem o pessoal da UEFS e começaram também a mostrar para a gente como se faz a coleta seletiva. A gente não sabia o que era coleta seletiva, não sabia como separar, não sabia que tudo ali poderia ter um valor ou não ter valor nenhum ${ }^{s 4}$. Começamos com a escola, conscientizando os alunos, do que era necessário fazer, o que poderia se aproveitar desse lixo, o que não poderia, as pessoas da comunidade nos seus fundos de quintal como deveriam limpar, como deveriam selecionar, o que poderia servir, ser útil para o próprio solo, para a própria terra que eles plantassem e correndo atrás da prefeitura para poder também nos ajudar, juntamente com a Secretária de Saúde na

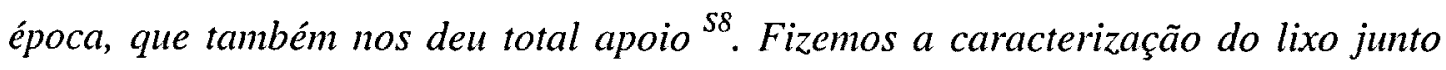
com especialistas da UEFS, fomos para as ruas fazer essa conscientização, e tudo foi a parte agradável, onde a gente conseguiu fazer a transformada ${ }^{54}$. A Selma com o trator e o pessoal da comunidade, saímos pegando o lixo, aquilo era uma forma de mostrar que a gente queria uma coisa diferente, que a gente não queria o lixo naquele espaço ${ }^{S 8}$. E aí foi tendo aquela experiência toda da coleta, de pesar, com a comunidade toda envolvida $^{S 2}$, e aí fez aquela cartilhazinha que foi distribuída nas casas $^{52,58}$, teve reuniões na escola e no salão várias vezes ${ }^{58}$ e também teve algumas oficinas de reciclagem de papel, brinquedos, práticas leitoras, roda de costura $e$ como lidar com o lixo ${ }^{59}$.

Começamos a fazer desenhos e imaginar de que forma a gente queria ver a frente da escola, que era uma coisa que estava incomodando ${ }^{54}$. Daí fez um jardim para mostrar que aquele espaço poderia ser utilizado para outras coisas e não para aquela coisa horrivel que prejudicava ${ }^{58}$. Enfim, foi uma alegria tremenda, poder desenvolver todas essas atividades do plantio da beira do rio ${ }^{\text {S3,S10 }}$, a formação do jardim em frente à escola que não foi realizado ainda mas que talvez ainda venha a se tornar uma realidade, de preservar os jardins, a limpeza, de se preocupar com a limpeza da rua, a questão do lixo, da coleta seletiva, da compostagem ${ }^{\text {S3,S10 }}$. 


\section{Idéia Central:O projeto proporcionou a Mombaça}

\section{DSC 4}

Eu acho que valorizou muito aqui a comunidade com esses projeto e com essa Associação ${ }^{s 3}$. Os meninos já estão sabendo que não devem jogar lixo no chão, que não devem estar destruindo, e a escola também envolvida com esse processo. Tanto é que você vê a Mombaça antes e hoje, a gente já nota uma diferença, e todo mundo tem aquela preocupação de ter seu jardinzinho ${ }^{\text {ș }}$. Um planta um aqui e outro planta acolá, ai todo mundo começou a querer fazer um jardinzinho. Antigamente era assim, você plantava hoje, quando fosse no outro dia podia ir lá que estava

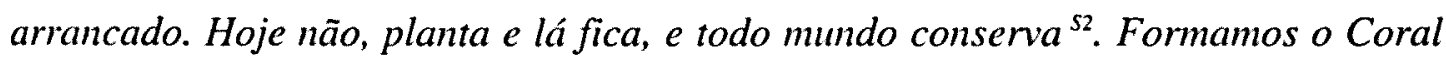
Terra Viva. e nesse coral, a gente envolveu não só o canto lídico, mas também o canto do meio ambiente, o canto da gente aqui que é Mombaça ${ }^{\text {s4 }}$.

E o lixo também, eu estou achando que ele está mudando, porque o pessoal tem u'm novo olhar. Hoje em dia, na rua mesmo, em que eu moro todo mundo já coloca o seu lixo separado, o que é entulho bota numa vasilha e o que é para ser reciclado em outra e, aí, quando a caçamba passa já pega ${ }^{52}$. Acho que com a coleta seletiva ajudou muito a gente a conhecer cada espaço, o valor de cada material e também a origem daqueles materiais ${ }^{\mathrm{S4}}$.

Criamos a praça, criamos a compostagem, um dos espaços de compostagem e espaço do material reciclável ${ }^{\text {st }}$. A comunidade foi bem beneficiada com o projeto. As pessoas têm uma outra conscientização sobre o lixo ${ }^{\text {sto }}$. Mas o trabalho de conscientização acho que fica para cada um, o trabalho de conscientização não fica exposto só fica exposto quando ele tem esta interação. Mas o que cada um aprendeu está dentro de cada um. Eu acho que quem está fazendo compostagem hoje no fundo do quintal, está fazendo porque teve um aprendizado em cima do que foi captado e os outros que faziam e não estāo fazendo mais foi porque desacreditaram ${ }^{\text {st }}$. Todo mundo pode ter compostagem no fundo do quintal e daquilo tirar alguma renda e aí é que dá o resultado, fazer as mudas de planta também é outra coisa que dá resultado e a reciclagem de papel que esta sendo uma das coisas mais fortes que estamos tendo diante desta parte ambiental ${ }^{\text {s4 }}$. 
Para mim, esse projeto foi muito útil, porque me deu condições de rever a minha vida toda e começar de novo de onde eu parei, tentando aprimorar $e$ melhorar cada vez mais o meu conhecimento. Eu trouxe de volta através desse projeto, os meus escritos, pois eu gostava muito de fazer versos, de escrever pensamento, e teve uma época em que eu deixei, parei tudo isso, e com esse projeto eu me senti assim revitalizada ${ }^{s 3}$.

Devido ao trabalho da Mombaça que foi apresentado na jomada pedagógica com os professores, São Felipe já está querendo implantar também a coleta seletiva, a usina de lixo, já está olhando também para esse lado ambiental e a vontade também de lidar com essa área ambiental ${ }^{\text {s4 }}$.

\section{Idéia Central: Projeto na Escola}

\section{DSC 5}

Antes, o trabalho de Educação Ambiental em nossa comunidade não era aquela coisa aberta para o público em geral da nossa comunidade. Depois que o projeto começou a atuar, os professores juntamente com os alunos e a família deles se conscientizaram a respeito do que é um trabalho sobre o lixo, do que é um trabalho sobre a preservação da natureza e hoje a gente já vê a coisa tocando não no total desejo, mas já aceitando a proposta de como trabalhar com a Educação Ambiental ${ }^{\text {s7. }}$. Todo jardim que tem aqui na frente da casa de algum estudante, pode ter certeza que ele já tem aquela preocupação ${ }^{52}$.

Os trabalhos na escola chegaram com os técnicos de outras cidades e até com os de Feira de Santana, fazendo o trabalho da coleta seletiva porque a gente não sabia trabalhar com o lixo selecionado e dai já foi deixando aberto como se trabalhar na escola com a compostagem. $O$ próprio lixo orgânico que era retirado da merenda escolar de que se fazia uso, já se botava, assim, na composteira e também a limpeza na área da escola. Na área interna da escola, as crianças não jogavam mais o plástico à toa, já tinha seu lugar selecionado e também a conservação do meio ambiente da escola. Já não se depredavam mais as árvores, não acabavam mais com a jardinagem que era feita na própria praça ${ }^{S 7}$. 
Ontem, eu pedi para os meninos fazerem uma pesquisa na escola sobre a nossa comunidade e o que é que tem nesse lixo que a gente passa todo o dia em frente à escola, o que pode ser reciclado e o que não pode ser reciclado. Então, eles souberam responder, qual a utilidade do vidro, se o lugar do vidro era ali e eles já sabiam que não. Os alunos já têm lıma consciência, embora eles não saibam reivindicar ou pedir para ser diferente. Mas eles já sabem o que pode ser transformado, que o lixo pode causar doenças. Falamos da dengue, então essa consciência eles têm. A maioria dos pais falam: para que isso? eu sempre joguei lixo ali. Então eles já criam, a coisa boa é isso, porque já vai se criando neles essa visão nova, que os pais deles não tinham ${ }^{\text {s8 }}$.

\section{Idéia Central: Frustrações}

\section{DSC 6}

O que mais frustrou, na questão ambiental, foi o entrosamento com o poder público ${ }^{52.54}$, porque a prefeitura deixou o jardim em frente da escola virar um montante ${ }^{S 2}$, quer dizer os garis vieram, pegaram as baias que tinham sido feitas no espaço, separando o lixo orgânico, do lixo seco, levaram tudo junto e acabou aquele espaço ${ }^{s 4}$.

Tivemos, na gestão passada, até um certo apoio, fornecendo as mudas de plantas, algumas vezes trazendo até os garis para que agissem com a gente nesta questão. Acho que o entendimento do poder público era errado, eles achavam que aquilo poderia ser um absurdo para eles investirem na parte ambiental daqui, no lixo da comunidade. Eles achavam que botando a caçamba e carregando de qualquer jeito era a forma correta ${ }^{54}$.

A gente deixou a praça bonita, todo mundo participando numa boa, cantando, fazendo mudas, plantando, daqui a pouco pelo simples fato de não recolher o lixo, a comunidade começou a desacreditar que aquilo poderia ser viável, que tudo só poderia se conseguir através do poder público e isso foi que deixou que a pracinha voltasse ao lixão de sempre ${ }^{s 4}$.

Então, para mim, hoje, a gente passa na Mombaça e vê a caçamba passando e pegando o lixo nas portas, chegando nos mesmos locais onde tem os lixões, 
fazendo a coleta da mesma maneira que antes, porque não faz a coleta de maneira que a gente tinha conscientizado o povo? Então, para a gente reabilitar essa ação novamente vai ser começar tudo do zero ${ }^{\text {s4 }}$.

\section{Idéia Central: Conheço pouco sobre o projeto}

\section{DSC 7}

Eu conheci o projeto através de D. Selma ${ }^{55}$, eu não participo ${ }^{54,56}$. Eu fui dar uma olhada ali no jardim, eu não participei, que nem me convidaram, eu fui olhar e gostei $^{\text {ss }}$.

Às vezes, também, quando tem qualquer coisa eu nem sei. Às vezes D. Selma, quando está aí, me chama, me avisa. Quando eu venho saber já terminou e, às vezes, eu também não posso ir ${ }^{\text {s6. }}$.

Sei que o projeto faz negócio de doce, artesanato, um bocado de coisa. Tudo que vem na cabeça do povo, o povo faz. Minha menina sempre quando está aí, participa de reunião, mas eu, é difícil ir lá, no lado de baixo da rua. Para ser franca eu queria que tivesse um negócio para dar um trabalho à gente. Para a gente ter um trabalho ali para dizer, eu estou trabalhando, eu estou recebendo. É bom, porque os que elas estão fazendo é bom. Se acontecesse de fazer isso que elas tão planejando ai era uma boa aqui para o lugar, que é um lugar pequeno, mas por enquanto. $O$ negócio do lixo agora é que está melhor, não está acumulando, isso aí já é uma vantagem. Já está fazendo coisa aí, mas aí eu não sei explicar quase nada desse projeto, porque eu não estou participando. Eu fui convidada e tudo, andei lá um dia ensinando um crochê também e tudo, mas eu parei. Participar é para eu estar constante com as outras, negócio de doce tudo que elas fazem e tudo. A minha menina é que aprendeu um bocado, a minha menina tern até o diplomazinho que trouxe de Feira, meu menino também participou em Feira ${ }^{\text {s6 }}$. 


\section{Análise da questão 1}

Através dos seis discursos inicias apresentados pelos moradores do Arraial de São Francisco da Mombaça sobre os seus conhecimentos em relação ao projeto é possível visualizar como foi o desenvolvimento do mesmo.

Uma situação problema observada, inicialmente, por alguns moradores locais o "Rio dos Pilões está secando", questionada em conversas informais, desencadeou todo um processo. A busca de informações sobre o problema e a formação de parcerias desencadearam uma ação coletiva que foi o plantio de mata ciliar nas margens do rio local. Importante observar que, através do conhecimento, houve a percepção das pessoas da interdependência entre a ação humana e a degradação do ambiente (transformação da lavoura em áreas de pastagens para a criação de gado) tendo como conseqüência, a degradação do rio.

Essa ação coletiva entre jovens, adultos e idosos para o plantio de árvores às margens do rio foi muito lembrada como um exemplo para a realização de outras ações. Também, a construção da praça no terreno onde era depositado o lixo seguiu este modelo e foi comentada inclusive, por moradores, que dizem não participar do projeto.

A situação problema inicial suscitou outras, a partir do olhar crítico despertado pelo conhecimento adquirido e pela mobilização da comunidade. $O$ lixo, que não chamava atenção, passou a ser um problema e esse fato conseguiu agrupar pessoas da comunidade para a busca de resolução. O processo para a solução do problema do lixo depositado no terreno em frente à escola levou em torno de dois anos. Cada passo foi planejado e executado participativamente, desde a pesagem do lixo, ação com objetivo técnico e, até, a concepção da praça, a qual foi baseada em desenhos resultante das oficinas realizadas durante o projeto "À Sombra de Uma Jaqueira". O papel da Educação Ambiental, como estimuladora da consciência crítica sobre a problemática ambiental, foi fundamental, na medida em que propiciou a ocupação do espaço público, antes usado somente para receber o lixo, para espaço de todos, inclusive do lixo, através de uma solução criativa diferente da tradicional. 
As oficinas utilizadas como atividades educacionais e realizadas durante o desenvolvimento dos projetos "Terra Viva - o queremos? E "À Sombra de uma Jaqueira" procuraram resgatar e valorizar a memória cultural do lugar. O incentivo à leitura de textos e do contexto despertou a capacidade de contar e escrever histórias e a valorização pessoal dos participantes. Conforme DEMO (1999), “a identificação cultural apresenta, talvez, a motivação mais imediata à participação”. Inspirou uma nova sensibilidade, uma vez que se precisa do lugar onde se vive e do relacionamento interpessoal. E, segundo a coordenadora do projeto, foi inspiração para o novo:

“... a memória está tendo esta importância, de pegar os saberes de antigamente e trazer à tona, como, por exemplo, o repertório do coral que traz, nas músicas, as cantorias dos tempos em que se colhiam café. Há muito tempo que não se colhe café em Mombaça, não existe mais a produção de café, mas o canto foi relembrado pelas pessoas mais antigas e isso veio para as vozes dos meninos do coral e isto está presente no repertório deles. Agora, é importante que a gente não fique só lá atrás, lembrando, lembrando, que pena, que esse tempo já passou, mas que bom que esse tempo, embora tenha passado, a gente possa hoje estar alimentando as novas gerações e, ao mesmo tempo, enxertando isto com coisas novas, fazendo novas composições" (Coordenadora do projeto).

As parcerias conseguidas durante esses anos de desenvolvimento do projeto foram excelentes oportunidades que as pessoas da comunidade tiveram de entrar em contato com outras experiências, tanto fora do espaço local, como no contato, durante as oficinas na escola. É importante salientar a importância da coordenadora do projeto na articulação para a formação dessas parcerias entre a comunidade e a rede de Leitura (comitê de Salvador), Universidades e a Prefeitura. "Ninguém se emancipa sem a ajuda dos outros mas o processo de emancipação implica em dispensar essa ajuda" (Carr et al., 1998 citado por DEMO 2001).

Nota-se a grande frustração em relação à não cooperação do poder público no manuseio do lixo, conforme combinado, e na forma atual pela qual o resíduo está sendo coletado, diferente do concebido pelo projeto, isto é, sem segregação na fonte.

As pessoas que dizem não conhecer o projeto, têm consciência de que é devido a sua participação. As alegações que levaram os sujeitos a não participarem 
do projeto foram a falta de tempo e a falta de convite com antecedência. Também alegam que o projeto deveria gerar emprego e renda. Esta preocupação também está presente nas pessoas ativas da comunidade e da Associação. A formação da Associação foi um produto importante obtido pelo projeto.

\subsubsection{Discurso do sujeito coletivo sobre mudanças ocorridas no Arraial em função do projeto}

A representação das mudanças ocorridas em Mombaça em função do projeto está alicerçada em três idéias centrais básicas. Mombaça mudou:

a) em relação ao lixo;

b) em relação às pessoas da comunidade;

c) em relação às áreas verdes.

Há um discurso em que o sujeito afirma que não estava vendo mudança porque não houve geração de emprego.

\section{Idéia Central: Mudou em relação ao lixo}

\section{DSC 1}

Mudou, mudou em relação aos professores, mudou em relação à comunidade O pessoal, antigamente, não tinha consciência, eu queria dizer, vivia o lixo muito à toa. Hoje, eles já estão deixando na porta de casa o lixo amarradinho e a prefeitura já manda o carro pegar, pelo menos duas ou três vezes na semana, apesar de que tem aqueles que ainda colocam no mesmo lugar de antigamente, mas são poucos, porque é difícil a gente conscientizar uma comunidade inteira em pouco tempo. Eu acho que é uma coisa longa de acontecer ${ }^{S 1}$. Então além da consciência dos adultos,

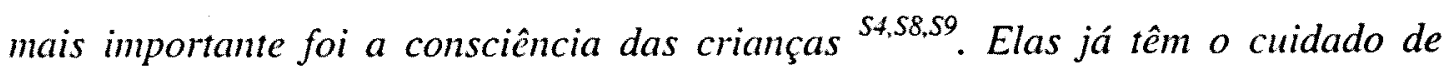
quando jogam o lixo, sabem que aquilo é desagradável, que aquilo pode causar doenças ${ }^{\text {SI,S4,S9 }}$, através de vários insetos transmissores e, também, o vento pode levar aquelas coisas todas ${ }^{58}$. Eu mesmo fui uma das pessoas que mudei junto com o projeto, porque eu gostava do plantio e via no meio ambiente pouco resíduo sólido, gostava mesmo do replantio. Mas não tinha muito olhar para esta questão do lixo. 
Então, em cima disto, fui criando novos hábitos em relação ao meio ambiente e à própria coleta que eu não conhecia, em relação mesmo à compostagem ${ }^{54}$ que já serve como adubo para as minhas plantas. Outras pessoas daqui conseguiram, no fundo do quintal, fazer sua compostagem ${ }^{58,59}$. A compostagem veio em boa hora porque antes a gente jogava o lixo orgânico na rua e no próprio lixão e, agora, o povo está sabendo como aproveitar o lixo. Eu estou lidando agora com biodigestor ${ }^{59}$.

Hoje, também, para muitas pessoas fica claro o que é lixo seco, o que é lixo molhado. O molhado é orgânico e o seco, inorgânico. Veja bem, eu mesmo, aqui em casa, antes pegava o lixo, tinha um buraco enorme, nesse buraco ia tudo. Era escavado bem fundo, quando enchia, comparava gasolina e botava fogo e ele ia baixando, e a gente continuava jogando. Quando não era possível mais jogar, fechava e abria-se outro, então mudou. Aqui mesmo separa-se o que é orgânico e inorgânico e se queima só papel do sanitário, o papel higiênico ainda se queima ${ }^{S 8}$.

A gente sente que as pessoas não têm dificuldades em assimilar o que se propõe. Agora tem que estar acoplado a outro assunto: econômico ou a qualquer outro. Porque o lugar é carente; se não fosse carente, a comunicação seria mais fácil. Agora, o que tornou a comunicação satisfatória foi justamente o lugar pequeno e o pessoal de uma hora para outra viu que o lixo é um problema. Foi se criando um lixão aqui, outro ali, e o pessoal via que estava se criando lixo. Antigamente, tinha pouco detrito inorgânico e ele imediatamente se decompunha sem criar problema. Mas quando começou a ter muita lata, muito plástico, o pessoal viu que aquilo era um problema, que crescia de uma maneira que a pessoa não imaginava que o crescimento era aquele ${ }^{S 11}$. O povo sabe que o lixo é um problema muito grande no Brasil e no mundo inteiro, então eles estão se conscientizando bastante. Antes a quantidade de lixo na Mombaça era grande mesmo, agora é pouca, já reduziu bastante a quantidade de lixo ${ }^{59}$.

Foram abrindo também novos campos para a comercialização e para o emprego, porque a gente aprendeu com o pessoal da UEFS e com outras pessoas que também passaram por aqui sobre a reciclagem, a parte de Educação Ambiental. Aprendeu como se recicla o papel, o papel que ia ser jogado fora pode se reciclar $e$ ter um valor comercial, podendo dar sobrevivência a algumas pessoas através disso. 
O adubo orgânico, da mesma forma, pode ser comercializado. Até os mais novos aprenderem a confecção de brinquedos criativos com sucata, com o plástico mesmo. A maioria não sabia nem qual era a origem do plástico, de onde se tirava o plástico, hoje já tem essa noção. Hoje, aqui não tem mais campo de fumo e as pessoas ficam lamentando, quer dizer, hoje o fumo não pode dar resultado, mas o papel a gente está vendo que está dando resultado, começando, no mínimo, a achar que dá resultado ${ }^{S 4}$.

\section{Palavra Chave: Mudou em relação às pessoas da comunidade}

\section{DSC 2}

Mudou, eu acredito que mudou, a começar pelas crianças. As crianças de agora estão valorizando mais as coisas, estão mais consciente do seu valor dentro da escola, na sua criatividade. Estão mais participantes, prestam mais atenção quando a gente fala ${ }^{S 3}$. Um bocado de menino que não sabia nada, fazer crochê $e$ bordar, que não bordava, fazer pintura, brincar de fazer arte, de fazer toda semana arte, um bocado de coisa ${ }^{\text {S5. }}$.

Mudou também em relação aos professores, mudou em relação à comunidade, mudou a consciência das pessoas, mudou o jeito assim do estudante ver e criou ânimo, que até as pessoas idosas voltaram a estudar ${ }^{S 1}$. A gente sabe que quando as pessoas estudam tem possibilidade de ver as coisas com outros olhos, mudou o olhar das pessoas, mudou muito mesmo. Até em mim mudou e fui buscar a aprender algo para poder sobreviver. Quantas pessoas aprenderam a fazer crochê durante o primeiro periodo do projeto, fazer colchinha de retalho e a se aperfeiçoar? Quantas professoras estão querendo ai estudar mesmo para fazer vestibular, querendo aumentar o grau de conhecimento ${ }^{S 2}$ ? Mudou, o projeto foi assim como uma gota d'água no oceano, foi uma maravilha, criou uma nova expectativa de vida nas pessoas daqui. As pessoas daqui aprenderam a ter esperança, acreditar que o que sabem, mesmo não tendo nível superior, o que sabem é capaz de mudar a história ${ }^{\text {S2. }}$.

Eu acho que mudou muito também a respeito da visão local ${ }^{S 3}$. As pessoas já têm um ponto de referência dentro da comunidade que é a Associação 
Comunitária $^{S 3}$. Isso valorizou muito aqui a comunidade. Aos poucos as pessoas estão tentando se organizar melhor, porque antes era mais difícil a comunicação ${ }^{S 3}$. Agora a gente já tem uma facilidade, já tem o ponto de referência que é o salão paroquial onde a gente se encontra e, desenvolveu bastante, até a própria linguagem $^{S 3}$ que com todo esse conhecimento que nós tivemos, com toda essa vivência durante o projeto com as pessoas que vinham de fora e que desenvolviam as oficinas aqui, a gente está mais desinibida, a gente também aprendeu a conversar mais claramente ${ }^{S 3}$, isso nos ajudou muito. Eu acho que a capacidade de raciocínio das pessoas que freqüentam, que participam da associação agora aumentou, estão tendo uma visão bem mais ampla do que tinham antes ${ }^{S 3}$. Mudou no sentido da conscientização da população, da conservação do solo, mudou tudo no sentido geral, o povo está muito mais consciente ${ }^{\text {S10 }}$.

\section{Idéia central: Mudou em relação às áreas verdes}

\section{DSC 3}

Mudou. A visão do povo não é mais a visão do passado, já sabe mais ou menos o que é uma Educação Ambiental, o que é plantar, o que é deixar para conservar, não é derrubar por derrubar; hoje já se tem consciência ${ }^{57}$. Antes, eu achava que a própria prefeitura se incumbia de fazer o trabalho de podação, de plantação de canteiros de jardins na pequena praça que nós temos na comunidade, mas, hoje, os próprios moradores, depois desse trabalho, eles mesmos já vão lá e preparam seu canteiro ${ }^{S 7}$.

Hoje, Mombaça tem muito verde que não tinha antes, já surgiram mais jardins, você vê que na porta de casa, de cada casa já tem um pequeno jardim feito pelas próprias crianças da comunidade, então isto é muito importante ${ }^{S I}$.

\section{Idéia Central: Não estou vendo mudança}

\section{DSC 4}

Para ser franca, eu não estou vendo nada ainda de mudança, a não ser $o$ negócio do lixo, que, pelo menos, deram em cima e estão tirando. Nada tem feito, ainda, não tem um local de trabalho para ninguém ${ }^{\text {S6. }}$. 


\subsubsection{O Discurso do Sujeito Coletivo sobre as mudanças pessoais ocorridas em}

função do projeto

Três idéias centrais foram obtidas nas respostas dos entrevistados à pergunta: $\mathrm{O}$ projeto mudou você?:

a) Mudou porque eu não sou a mesma pessoa;

b) Mudou minha atitude em relação ao lixo;

c) O projeto não provocou mudança.

\section{Idéia central: Mudou porque eu não sou a mesma pessoa.}

\section{DSC 1}

Olha, eu acredito, que principalmente dentro de mim, mudou muito. Eu nasci aqui, eu nasci cuidando da terra e achei que sabia tudo e, através do projeto, eu descobri que nada eu sabia, ${ }^{\text {sI }}$ eu tive a oportunidade de aprender muita coisa e a cada dia que passa, eu aprendo mais ${ }^{S 2}$. Eu, antes, era uma pessoa comum, agora eu não sou mais uma pessoa comum porque desde que o projeto iniciou minha vida já mudou bastante ${ }^{59}$, tomei consciência de mais coisa que não tinha, não só do meio ambiente mas o convívio com outras pessoas também me ensinou bastante coisa ${ }^{\text {S10 }}$. Antigamente, pelo fato de ser menos esclarecida, a gente ficava assim sem falar, ele vai responder mal e eu não vou gostar. Hoje, a gente já tem um preparo, mesmo que as pessoas nos respondam mal, a gente vai persistindo naquilo e tem um preparo psicológico para não se aborrecer por tudo ${ }^{510}$. Então, mudou muito dentro de mim, eu consigo me relacionar melhor até com as pessoas através desse projeto ${ }^{\text {S1 }}$. Mudou porque aprendi muita coisa e as minhas críticas não são tão ferrenhas porque sei que as coisas não são fáceis. Antes, eu criticava muito e a gente tem que ver que esses problemas de Educação Ambiental são coisas sérias ${ }^{s 8}$.

Para mim, isso foi uma abertura muito grande, me beneficiou muito e continua me beneficiando, porque até os estudos eu voltei a retomar ${ }^{53,510}$, através desse projeto. Eu senti a necessidade de ter um desenvolvimento maior, de 
aprimorar mais a minha cultura também e me ajudou muito porque hoje eu já levo coisas do projeto para dentro da minha escola ${ }^{\text {SI }}$. Hoje eu sou procurado, tenho esse reconhecimento, não só aqui mas até a nível nacional ${ }^{S 4}$ e estou sobrevivendo hoje também em cima do que aprendi. Hoje estou dando aula de canto porque o projeto proporcionou a vinda de um especialista em música. Hoje posso chegar, falar de compostagem, do material orgânico, porque teve especialista que veio para mim Hoje eu posso repassar esse aprendizado. eu posso falar também no replantio, porque teve pessoas que vieram repassar isso ${ }^{\mathrm{S}}$.

Eu gostaria muito de falar também sobre a leitura. Hoje eu aprendi a ler, antes eu lia por ler e também acredito que nem sabia ler. Eu aprendi a ler, a fazer a leitura visualizada, é aquela coisa de você, só de você olhar, você sabe ler. Hoje eu tenho prazer em pegar um livro, ler e escrever sobre ele, sobre o que eu li, é uma coisa que aprendi dentro do projeto ${ }^{\text {sI }}$.

\section{Idéia central: Mudou minha atitude em relação ao lixo}

\section{DSC 2}

Claro, dentro de mim eu já estou totalmente inspirada nessa visão, já gostava da natureza antes e, agora, mais ainda. Hoje já sei plantar na minha casa, já sei preparar o meu adubo orgânico no meu próprio quintal, você pode chegar lá e ver tudo arrumadinho, as plantinhas: no caso alface, hortelã, coentrinho, temos semeado e com o nosso próprio adubo feito em casa ${ }^{S 7}$. Antes, a primeira coisa que a gente faria era comer uma banana e jogar a casca, não importa onde ela caia, $e$ depois, através do projeto, a gente começou a se conscientizar, eu principalmente, sofri muito no início porque eu tenho três filhas e o marido, e meu marido era o primeiro a dizer assim: deixa de ser boba, menina, não coloca no lixo não, joga aí mesmo. Para mim, foi difícil no início, mas, graças a Deus, hoje eu já o conscientizei de que a gente tem uma compostagem de que ali é que se deve colocar. Para mim é muito gratificante, antes eu achava que dentro de casa estando limpo, fora não precisava estar muito e hoje já mudou muito; hoje você já encontra, na minha casa, uma compostagem, já encontra mais plantas que não tinha, mais árvores e mais 
verde ${ }^{S 1}$. Embora antes eu já fazia alguma coisa lá no fundo do quintal, mas procurei fazer de uma maneira mais organizada ${ }^{\text {SII }}$

Antes eu não pensava quando via uma lata comum no lixo. Não sabia que podia se transformar em brinquedo de sucata, não sabia que os restos de comida, essa coisa orgânica, se transformava em adubo para as plantas, então isto é uma transformação que veio em boa hora para eu me conscientizar mais das coisas ${ }^{\text {s9. }}$.

\section{Idéia central: Não mudou}

\section{DSC 3}

Não, porque eu nunca participei dessas coisas. Quem participa mais é o jovem que faz essas coisas. Tem negócio de canto, assim os jovens que faz para cantar, aí nunca me chamaram. Também não tenho voz ${ }^{S 5}$. Então, a minha vida tá no mesmo. Porque aqui, que nem eu digo, deveria ter um trabalho, fosse abrir uma fabricazinha, qualquer coisa para o pessoal trabalhar, porque aqui não tem trabalho. Onde tinha trabalho era num campo que tinha aqui, era até meu marido que tomava conta, mas depois que acabou esse trabalho... quem trabalha fora, trabalha. Aqui só é o lugar dos aposentados, quem não é, está mal ${ }^{56}$.

\section{Análise dos discursos do sujeito coletivo obtido das questões sobre as mudanças ocorridas tanto no Arraial como em termos pessoais.}

A representação dos moradores locais em relação às mudanças ocorridas no Arraial devido ao projeto foi, em termos objetivos: diminuição do lixo pela realização da compostagem e a organização dos resíduos nos próprios quintais; a colocação do lixo em sacos para apresentação à coleta pela prefeitura; e os vários jardins em frente às casas que começaram a aparecer e sendo efetuados pelos alunos da escola. Também a conquista do espaço do salão paroquial para a realização das reuniões, da oficina de papel e de outras atividades da Associação tornando-se um ponto de referência para os encontros com a comunidade. Há, na comunidade, uma nova percepção sobre o lixo no sentido de sua valorização, tanto em atividades 
artísticas como para sua utilização em hortas domésticas o que, antes do projeto, para muitos, era algo desprezível ou nem percebido.

É muito forte a mudança subjetiva em relação ao aprendizado, o despertar para a questão do lixo que estava se acumulando e trazendo problemas ambientais e de saúde, o desenvolvimento da linguagem e a percepção de que cada um pode ser um agente de mudança, não interessando o nível de escolaridade e, sim, mediante o saber individual. O projeto incentivou a volta aos estudos, permitiu uma melhor comunicação e a possibilidade de aumento da renda para alguns. Em resumo, uma importante área de mudança observada está relacionada ao empoderamento individual em termos de educação, relacionamento interpessoal, capacidade de expressar seus pontos de vista e de reivindicar, conscientização, prática ambiental e até a satisfação da mãe com as novas práticas na escola.

Segundo a coordenadora do projeto, não existe uma obra física resultante do projeto. O que é muito forte é a valorização da pessoa da comunidade e do desenvolvimento da consciência crítica.

"No tempo em que a gente pensa no projeto, a gente pensa numa coisa que passou e não deixou nada, porque não há nenhum marco, não há nenhum monumento, não há uma coisa física que marque a existência desse projeto $\grave{A}$ Sombra de uma Jaqueira. Se a gente chega no Arraial hoje, ele continua sendo aquele mesmo Arraial, cono há 5 ou 10 anos atrás. A gente não vê nenhum marco que se diga: aqui houve um investimento, a gente gastou grana para fazer esse marco. Mas existe outra coisa que, se a gente quiser, a gente enxerga: os jardins de frente do povoado, as flores que estão ali e que aparecem, o zelo é do próprio grupo da comunidade, não é da prefeitura, pelo contrário, não é uma questão puíblica que está zelando desses jardins, são os moradores que estão construindo. Hoje, a gente já sabe o que quer, já sabe também o que não quer, então isto é um salto que faz parte do patrimônio visivel do projeto que é a consciência e o sentido de cidadania. A gente diz que o "papel" do artesão da Mombaça é o papel do cidadão, porque à medida em que ele vai fazendo seu papel, ele vai tendo consciência de sua própria prática de cidadania. A gente diz que o canto do Coral Terra Viva, do grupo Cantação é um canto da cidadania porque cada ação está sustentada por um conhecimento, de que a gente passou a acreditar que cada pessoa é capaz. Cada um 
tem o direito de ser feliz, cada pessoa tem o seu merecimento, não é por ser um povoado, um lugar pequeno que vamos deixar para lá. Então, acho que é um trabalho que tem uma repercussão bonita, porque é uma descoberta, há uma valorização de cada pessoa, de cada indivíduo, desde a criança, podendo ser valorizadas".

Importante o discurso das pessoas que percebem que o projeto não provocou mudança, nem em termos pessoais, nem como no Arraial. Segundo estes sujeitos, o grande problema da localidade é a falta de emprego e renda e o projeto não preencheu esta lacuna. Tentativas, realizadas pela Associação, para absorver as potencialidades locais como fabricação de doces, costura e artesanato tem sofrido entraves devido à falta de capacitação dos membros da Associação, na comercialização e na gestão empresarial que envolvem questões como formação de custos para o produto, sua colocação no mercado, entre outros. Iniciaram-se, no presente ano, oficinas com o intuito de capacitação para o cooperativismo, padronização dos produtos e busca de mercado para os que venham a ser produzidos.

Segundo Demo (1996 p. 85-87), a microprodução não tem apenas importância social (absorção da mão de obra), mas, igualmente, econômica e as políticas sociais e econômicas devem contemplar investimentos em produção que correspondam às reais vocações econômicas, fundadas em matéria prima existente, comercialização garantida e mão de obra disponível. Também devem dar apoio a estratégias de marketing (feiras), para que a produção tenha acesso ao mercado, consiga viabilizar-se em termos econômicos e financeiros, além de avançar na qualidade dos produtos. Investimento de caráter coletivo é importante para fomentar manifestações pertinentes a uma cidadania organizada e pode ocupar espaços significativos no comércio.

“... precisamos ir mais adiante, precisamos aperfeiçoar e verificar um pouco mais onde nós podemos suprir as falhas, as deficiências e crescer mais para chegarmos a encarar esse desafio que é essa coisa da busca de uma geração de emprego, de trabalho, uma coisa digna para as pessoas" (Coordenadora do projeto). 
4.2.2.4 Discurso do sujeito coletivo sobre a participação da comunidade no projeto

Três idéias centrais foram obtidas das entrevistas:

a) Eu participo de várias formas;

b) Às vezes me recuso a participar;

c) Não participo.

\section{Idéia Central: Eu participo}

\section{DSC 1}

Olha, eu acho que falar da minha participação do projeto, eu acho que é o espaço mais difícil, porque de tudo eu participo ${ }^{54}$. Eu me envolvo, eu tenho me envolvido no processo desde o primeiro momento em que ele apareceu, talvez não tenha participado de tudo por falta de oportunidade ${ }^{S 1}$. Eu participo na Associação da Mombaça ${ }^{S 11}$, eu já participei assim ajudando no coral, ell participo em reuniões ${ }^{S I, S 2, S 4}$ eu adoro dar opinião, se precisa ir, agir, eu faço mobilização, se tem assim alguma ação para divulgar, eu estou aí. Eu me envolvo em qualquer circunstância, para viajar, para fazer alguma coisa ${ }^{S 2}$. Eu adoro entender, aprender, eu sinto como uma troca, eu levando o que eu sei para passar e também recebendo aprendizagem $^{S 1}$. Se estou brincando, eu estou falando do projeto; se eu estou dando minhas aulas, estou falando do projeto. Se eu estou junto com a comunidade, eu estou falando do projeto ${ }^{54}$. A minha atuação tem a visão de conservação do meio ambiente e atuo, também, como pessoa, conservando, plantando, colhendo ${ }^{S 7}$.

Eu participei do projeto de duas formas: primeiro como coordenadora da creche recebendo o pessoal de fora que vinha para as oficinas, na época ${ }^{58}$, como professora da escola ${ }^{S 7, S 8,510}$ e, também, como pessoa da comunidade ${ }^{S 7, S 9}$. Eu acho que a gente tem que crescer cada dia mais e ajudar o próximo. Se a gente aprende uma coisa boa, tem que passar aquilo, por exemplo, dentro de minha casa ${ }^{\text {S10,S11 }}$ conscientizando como devem ser as coisas. Eu participo dessa forma na comunidade em geral ${ }^{10}$ pois temos que ajudar o outro; participei de algumas oficinas de leitura, de reciclagem de papel, das latinhas e da reciclagem do lixo na escola ${ }^{58}$. 


\section{Idéia Central: Às vezes eu me recuso a participar}

\section{DSC 2}

Às vezes eu me recuso a participar porque eu me chateio, às vezes, quando a gente fala a verdade, cria certo tipo de problemas. Eu me chateio com as coisas erradas que a gente vê. Associação quer dizer associar, então, se tem uma venda, tem uma prestação de conta, se está na hora da reunião dos problemas e se tem um passeio, eu acho que todo mundo tem de ser comunicado e, às vezes, isso não acontece. Às vezes acontece de o projeto pagar um passeio e a gente não fica sabendo,agora se é um passeio para tirar dinheiro da gente, aí vem na porta convidar. Eu acho isso muito chato, eu acho isso muito irregular ${ }^{\text {S1. }}$.

\section{Idéia Central: Não participo}

\section{$\operatorname{DSC} 3$}

Não participo, não tenho nenhuma participação, não vou às reuniões ${ }^{\text {S5,S6 }}$.

\section{Análise da questão 4}

Para alguns sujeitos a participação é o envolvimento total com as atividades do projeto. Conforme SAWAIA (2001 p. 125), a participação, como potência, trata da passagem da passividade à atividade e adota, como indicador da eficiência da participação, a idéia de potência de ação. Potência de ação é a capacidade de ser afetado pelo outro, num processo de possibilidades infinitas de criação e de entrelaçamento nos bons e maus encontros, visando dar força ao sujeito. É o que se observa nessa comunidade, a vontade de que o projeto ande para que seus benefícios sejam distribuídos a todos.

Pelos discursos apresentados, o sentido de participação é representado pela:

- Conscientização e orientação de outras pessoas tanto no ambiente doméstico como na escola.

- Organização dos eventos realizados na escola e na comunidade. 
- Participação nas atividades proporcionadas pelo projeto (coral, oficinas, viagens, entre outras).

- Participação nas reuniões da Associação Comunitária, ou como associado da mesma Associação.

- Mobilização comunitária (impacto sobre as capacidades das partes interessadas em saber e agir).

O discurso construído a partir da idéia central "não participo" é justificado pela não presença em reuniões e nas atividades proporcionadas pelo projeto. A falha na comunicação também é citada como responsável pela não participação. Por convicção os sujeitos deixam de participar em alguns momentos porque a Associação não socializa as atividades programadas com todos, o que, para eles, é um desvio do objetivo do associativismo, que é a luta pelas questões de interesse coletivo e, não, dos interesses particulares de cada um.

\subsubsection{Discurso do sujeito coletivo sobre a avaliação do projeto.}

As idéias centrais que representam as respostas da comunidade são:

a) Proporcionar trabalho para jovens e adultos (geração de renda);

b) Desenvolvimento comunitário/envolver toda a comunidade através de um projeto de interesse geral;

c) Buscar apoio dos órgãos públicos e instituições;

d) Ter sede própria;

e) Melhorar a comunicação e realizar reuniões prévias. 
Idéia Central: Proporcionar trabalho para jovens e adultos (geração de renda)

\section{DSC 1}

É que nem eu estou dizendo, para melhorar Mombaça só trabalho, só trabalho. Se pudesse abrir uma fábrica de costura, porque costura hoje é que dá. Porque, aqui, para melhorar, só trabalho mesmo. Para mim, o melhor que podia ter aqui era o trabalho ${ }^{56}$. Também deveria ensinar os meninos a desenhar, fazer negócio de pintura porque tem um bocado de menino na rua, tudo vadiando. Eu queria arrumar um trabalho, eu gosto de cozinhar. Eu queria aprender a fazer doce. Eu não participei dos cursos de doces porque não me chamaram. Eu sou mais de idade e aí não chamaram ${ }^{55}$. O desejo da gente mesmo é que, no caso em que se fala tanto da fabricação de doce, tivesse tipo uma fábrica onde tivesse mais emprego e as pessoas pudessem ficar aqui e trabalhar, fazer seus doces aqui mesmo, ver sair e ser comercializado $^{S 1, S 10}$ lá fora, ter mais emprego porque aqui é uma carência total ${ }^{S 10}$. As famílias devem ter um meio de sobrevivência, uma renda financeira onde possam sobreviver, que tenha mais crescimento e que possa se sentir como cidadão mesmo, tenha uma vida digna, possa dar a seus filhos uma condição melhor de vida, uma educação melhor, uma saúde melhor, porque o sentido de trabalhar em comunidade é isso, que todos sejam beneficiados de uma maneira ou de outra. A gente já beneficiou uma parte nessa coisa de coleta seletiva, porque já tirou o acúmulo de lixo dos quintais, que isso causava muitas doenças; na rua já não está ficando mais esse acúmulo de lixo, provocando tanta doença nas crianças. Então, está na hora da gente buscar melhoria financeira, a parte econômica.... para desenvolver melhor ${ }^{\text {S2 }}$.

\section{Idéia Central: Desenvolvimento comunitário/envolver toda a comunidade através de um projeto de interesse geral}

\section{DSC 2}

Olha, o que eu acho que falta no projeto é desenvolver a parte comunitária, porque o projeto que nós tivemos ele foi mais voltado para a escola ${ }^{S 2,58}$, apesar da comunidade participar também, mas o vínculo maior foi com a escola ${ }^{S 2}$ e ele não podia ficar só em práticas leitoras, sem olhar as coisas que estavam ao nosso redor. 
A gente teria que dar uma chance para as pessoas, para compreender, entender $o$ que estava se passando dentro da escola ${ }^{58}$. É preciso que a gente desenvolva um projeto aqui para que a comunidade possa participar, independente do ponto de vista de cada um, sem exceção e que traga também atividades para o pessoal local, que eles possam sentir que eles também têm compromisso e têm uma atividade a desenvolver dentro da comunidade ${ }^{S 3}$. Trabalhar junto, como a gente fez no plantio das árvores na beira do rio que foi uma participação coletivas ${ }^{S 3}$, porque isso aí vai dar mais um incentivo às pessoas, as pessoas vão se sentir importantes ${ }^{S 3}$, porque quando eu estou lá dentro desenvolvendo junto com o pessoal aquela atividade eu vou saber que eu sou litil e que as pessoas precisam de mim, que a minha participação é muito importante, porque eu estou também ali dentro, fazendo parte daquele grupo. Então, eu acho que isso é que está faltando aqui, que venha um projeto para a escola, que venha um projeto para a comunidade e que possa desenvolver para poder dar crescimento, principalmente às famílias ${ }^{S 2}$. O projeto fica muita na parte teórica a parte prática fica um pouquinho a desejar. A gente vê mas o pessoal lá fora fica difícil de entender ${ }^{510}$. Então, o que está faltando no projeto é a interação da comunidade, o desenvolvimento da comunidade, juntamente com o grupo da Associação, porque muitas pessoas, às vezes, perguntam: o que é que a Associação está fazendo? O que a gente responde não agrada na maioria das vezes, porque ouviu falar que em tal lugar a Associação conseguiu uma casa de farinha, que conseguiu um poço artesiano e que aqui a gente não mostrou nada disso ainda. Mas eu acho que o nosso objetivo não é trazer uma receita pronta, mas trazer um trabalho de base, onde as pessoas possam estudar aquilo, ver de que forma pode ser feita para daqui a pouco estar fazendo qualquer coisa e ter pouco sucesso ${ }^{\text {S4 }}$.

Quando teve o projeto daquela pracinha, foi um sonho para todo mundo porque aquela pracinha, se tivesse sido colocada em prática, seria uma grande realização, mas ficou só o desejo, o sonho, e aí parou ${ }^{\text {sio }}$. Então, o importante é você fazer um trabalho que mostre os resultados o mais breve possivel porque é a única maneira de você convencer a população do que você está fazendo ${ }^{\text {SII }}$. O que está faltando para nós, aqui, é isso, o reconhecimento da comunidade em relação à educação e as ações que a gente está desenvolvendo, atrair a comunidade para a Associação ${ }^{54}$ e fortalecer mais as bases, as pessoas que sustentam ter mais 
envolvimento e aumentar a participação. Porque já tem um monte de gente participando, mas precisaria de mais pessoas ${ }^{\text {s2 }}$.

\section{Idéia Central: Buscar apoio dos órgãos públicos e instituições}

\section{DSC 3}

Eu acho que faltou um pouco também dos órgãos públicos. Eu acho que os órgãos públicos não se direcionaram, porque a nossa força era muito mais forte, nosso desejo de atuação era muito mais forte e eles ficaram meios dispersos, não por nós não convidar, o projeto não chegar até eles, porque como o trabalho era de Educação Ambiental, então faltou interesse dos órgão públicos ${ }^{57}$. Não só depende de estar com o pessoal da escola e da comunidade, porque o trabalho para ser tocado em melhores condições, eu acho que a prefeitura devia estar incumbida de alguma coisa $^{S 7}$. Há dez anos atrás, você não via esse problema do lixo na Mombaça e depois quando começou a se criar lixões e como aqui é um lugar pequeno chamou a atenção e isto foi bom porque despertou interesse nas pessoas em quererem resolver o problema. Para isso, chegou Selma, depois a Associação, depois chegou o pessoal da Universidade de Feira que deu aquele apoio para desenvolver o trabalho e quando chegou na hora $H$, o apoio oficial que precisava mesmo não foi recebido. $O$ que se fez ficou parecendo como se nada tivesse sido feito e quem estava fazendo ficou parecendo que não sabia fazer. Mas não foi pelas pessoas que fizeram, foi pela divisão política. Então, embora não ficasse bem para o projeto, não ficasse bem para a Associação e para outras pessoas envolvidas, ruim mesmo ficou para quem não soube aproveitar, que foram os órgãos oficiais ${ }^{\text {S11 }}$. A coleta do lixo, não posso dizer que não está fazendo coletivamente no meio da semana duas, três vezes na semana, mas faltou alguma outra coisa. Porque o que realmente a gente quer é que tenha um destino correto para o lixo da nossa comunidade ${ }^{S 7,58}$.

Para seguir o projeto, também eu acredito que precisa de apoio, de alguma entidade que esteja disposta a dar continuidade ao trabalho que já está começado, que já está conscientizado e que a gente precisa de pessoas que mobilizem esses empresários, porque o problema não é só nosso, mas deles também, mais do que nosso, porque quem fabrica as garrrafinhas, os sacos plásticos não somos nós. 
Então, que apareça alguma entidade que esteja disposta a trabalhar, que o pessoal daqui tem boa vontade ${ }^{S 8}$.

\section{Idéia Central: Sede Própria}

\section{DSC 4}

Eu acho assim, só o que falta no projeto é a sede própria. Hoje, a gente trabalha no salão paroquial e aí o pessoal não entende que tá ali emprestado para a Associação por um período. Mas tudo o que a gente tem que fazer lá tem que pedir a permissão do padre, então eu acho assim o que falta é, um dia, ter sede própria ${ }^{S 2}$, ter uma casa que abrigasse a Associação que a gente trabalhasse com mais segurança e com equipamentos certos ${ }^{s 9}$.

\section{Idéia Central: Falta de comunicações e reuniões antecipadas}

\section{DSC 5}

O que está faltando é o grupo se unir mais, falta união no grupo, falta comunicação. Nós não nos reunimos como deveríamos, por exemplo, se tem alguma coisa para acontecer, nós só vamos reunir com a coordenadora no sábado, então seria gratificante até para ela se a gente se reunisse sexta, discutisse o problema e quando ela chegasse, a gente já tivesse alguma coisa mais objetiva para entregar a ela. No entanto, nós ficamos esperando ela chegar no sábado e, se tem algum problema maior, a gente vai tentar discutir aos sábados, quando ela volta já é 15 dias depois, então tudo dificulta. Acho que o que falta mesmo é união, enquanto o grupo não tiver uma união melhor, não vai muito a frente, é isso que tá faltando ${ }^{\text {s1. }}$

\section{Análise da questão 5}

Depreende-se dos discursos do sujeito coletivo que é fundamental que os próximos projetos contemplem também a comunidade como um todo, que não fique apenas no âmbito da escola e que proporcione trabalho para jovens e adultos (geração de renda). A comunidade cansa quando entra no gargalo comum da 
discussão infinita, da reunião constante. Maior será a desmotivação quando se acaba por perceber que ainda não melhorou em nada. Emancipar-se é algo certamente político que demanda organização política, mas não sobrevive apenas com ideais, compromissos, ideologias e mobilização. Ao lado disto é mister saber resolver a questão da sobrevivência (DEMO p 125).

Observa-se que a visão do futuro e do coletivo está presente nos discursos dos sujeitos que se consideram participantes do projeto. Segundo TASSARA (2001, p.213), a participação é condição para definição do futuro. A questão da sobrevivência deve estar incluída nesse futuro.

A visão assistencialista encontrada em alguns moradores e sentida pelos sujeitos, está representada no DSC 2, quando comenta que outras Associações conseguem trazer melhorias, trazer "benefícios" para suas localidades, muitas vezes através de políticos oportunistas. Contudo, na visão dos participantes do projeto os benefícios devem vir através da decisão participativa dos moradores locais. SHERER-WARREN (2001, p. 47), referindo-se ao novo associativismo brasileiro, fala que "motivações para a participação nas organizações não são predominantemente para a conquista de interesses materiais objetivados, mas, sim, para conquistas mais amplas no terreno da cidadania (alguma forma de mudança social, participar de ambiente coletivo ou fortalecer a organização)".

Há clareza que, para execução de projetos, há necessidade do apoio financeiro e político de instituições públicas e privadas e que a construção de uma sede própria seria um referencial importante para a comunidade. Atualmente, a sede está localizada no salão paroquial e isso pode ser um empecilho para que indivíduos não católicos da comunidade sejam atraídos para as reuniões e atividades que se desenvolvam nesse espaço.

A circulação das informações referentes às atividades do projeto e da Associação devem ser melhoradas. E que as reuniões se realizem mesmo sem a presença da coordenadora do projeto, que não mora permanentemente no Arraial. Isso é um bom indicativo do desejo de emancipação. Segundo informações obtidas junto aos associados, no final do ano de 2002, a Associação elegeu a nova diretoria, sendo composta exclusivamente de moradores locais. 


\subsubsection{O Discurso do Sujeito Coletivo sobre a relação pessoal com o lixo}

Duas idéias centrais foram obtidas como resposta à pergunta: "Lixo: o que você tem a ver com isso? A primeira idéia central foi: "tenho tudo a ver, pois minha relação com o lixo mudou" e, a segunda, "não tenho nada a ver com o lixo".

\section{Idéia Central: Tenho tudo a ver pois minha relação com o lixo mudou}

\section{DSC 1}

Ah! Eu tenho, tenho muito, ${ }^{S 2, S 4, S 7, S 8, S 9}$ agora lixo, o lixo é que nem se diz uma frase, o lixo virou um luxo ${ }^{S 2}$, o lixo hoje não é o lixo ${ }^{S 1, S 3}$, eu já vejo o lixo como uma coisa boa ${ }^{S 1}$. O lixo, hoje, já não é lixo porque do jeito que a gente está tratando o lixo, a gente nem pode dizer mais que o lixo é lixo. Já tem tanta coisa hoje aproveitável dentro do lixo, que pode reciclar. O línico problema, ainda, do lixo é o plástico, porque ainda não se tem um destino certo para ele. Mas quase que hoje, o lixo que existe mesmo é o vidro, o plástico, a lata, o flandre, porque também é outro que a gente não tem um destino certo para ele, ainda não se encontrou o ponto de comercialização e fica difícil da gente acumular ele no quintal, porque chega um momento em que a gente não tem mais condições de ter aquele acúmulo e tem que botar fora mesmo ${ }^{S 3}$. Então, eu acho que eu tenho tudo a ver com isso, tanto na parte de conscientizar como na parte também de atuar nessa área ${ }^{S 4}$, porque a todo canto que eu vou, eu falo. Falo e se vejo: Ah! Não joga no chão não! Os meninos de casa, da escola, da creche, já sabem. Se você for na escola você não vê lixo à toa. $\mathrm{Na}$ creche, a mesma coisa, porque uma cidade limpa não é benefício para quem está na prefeitura, é um benefício para a gente própria, que a gente vai se tornar cidadãos organizados, tenho feito propaganda ${ }^{52}$. Hoje, até um papelzinho de bombom eu não consigo mais jogar na rua, porque eu fui sensibilizado com isso. Hoje, perto da minha casa, tem um lixão onde eu não jogo mais meu lixo, já fica a parte orgânica no meu quintal ${ }^{S 1, S 4}$ fazendo a compostagem e, no saquinho plástico, vai o que não pode ser reciclado. Porque aqui não tem como a gente reciclar esse outro lixo, a não ser o papel ${ }^{\text {S4 }}$. 
Eu acho que o lixo é uma questão mundial. O mundo todo se preocupa com a questão do lixo, mas dentro da minha comunidade, uma comunidade de 800 a 900 habitantes o povo já sabe o que significa o lixo, já tem uma consciência de como separar ${ }^{S 7}$ e a comunidade, aqui mesmo, já está se sentindo bem mais beneficiada com isso, porque já tem uma visão mais bonita, os quintais mais limpos, a rua também mais limpa e o aproveitamento que a gente faz também está vendo resultado nas plantas, no adubo, na compostagem, o huimus. A gente já não vai comprar adubo para colocar nas plantas, ou nas roças, na plantação da lavoura porque quem mora na roça pode fazer a compostagem e já tirar dali para fazer o plantio. Nós mesmos, quando começamos com esse trabalho da compostagem, a gente tinha assim um plano de poder fazer uma horta comunitária, onde a gente pudesse ter, não só frutas, como verduras, todos com produtos orgânicos para o desenvolvimento da fábrica de doce Sabores da Terra. Mas isso ainda não foi possível, e a vontade da gente, o nosso sonho é esse para o futuro, a gente conseguir depois da...sede própria, da associação a gente ter um local onde possa desenvolver essa horticultura ${ }^{S 3}$.

Eu tenho a ver com o lixo, eu sou dona de casa, sou professora, eu amasso papel, eu descasco verduras, tenho tudo a ver com issoss. Todos produzem lixo agora saber produzir e também saber como usar aquele lixo para não ser prejudicado e nem prejudicar a comunidade e usar o lixo como uma coisa agradável, fazendo a reciclagem, não colocar o lixo orgânico na rua. Aqui, hoje, graças a Deus, o pessoal que colocava o lixo em qualquer canto, com a conscientização está melhor, procurando botar em lugar determinado ${ }^{\text {S10 }}$. Então, eu tenho a ver com o lixo no geral, porque a gente vê que o lixo também pode gerar emprego. Lixo pode gerar também inquietação à proporção que você conscientize o homem de que também pode ser um meio para sustentar sua própria família. Antes da consciência, o lixo é lixo, mas depois que se conscientiza, ele pode saber que é ım meio de sustento para a sua família ${ }^{57}$ e, se a gente não tomar cuidado, ele vai estar por cima da gente. Tem tudo a ver ${ }^{58}$.

Eu estou procurando uma definição para o lixo e não achei. Eu procuro porque existe a parte do lixo em que a lata velha se transforma em lata nova, o alumínio se transforma em alumínio, o vidro se transforma em vidro e a parte orgânica se transforma em adubo. Então, quando a gente diz é lixo, parece que você 
mistura tudo e nada serve, a não ser para transformar qualquer parte do ambiente natural em ambiente feio. Então, até hoje eu procuro esta palavra realmente para me comunicar melhor e não achei, deve ser lixo organizado mesmo ${ }^{\text {sil }}$. Lixeiros são aqueles que não trabalham com o lixo, mas, sim, aqueles que lidam com o lixo no bom sentido. Não que viva do lixo mas que tire do lixo aquelas coisas boas, as coisas que prestam para fazer brinquedo, para tirar do lixo o composto orgânico e até tirar do lixo o próprio gás, agora a gente está fazendo que é o biodigestor. Então, o lixo antes era meu inimigo agora é meu amigo porque eu me dou com o lixo e sei como lidar com ele $e^{s g}$.

\section{Idéia Central: Não tenho nada a ver com o lixo}

\section{DSC 2}

O lixo ficava acumulando em frente ao colégio, era uma coisa triste junto do chafariz. Na verdade, eu não pego água lá, mas achava uma coisa ruim aquilo ali. Jogavam bicho morto, tudo ali era muito fedendo mesmo. Agora, o negócio do lixo devia ter um lugar reservado só para o lixo mesmo. Que nem estão fazendo agora tirando toda a semana, aí fica tudo limpo, a não ser isso, para mim tá tudo... Não tenho nada a ver com o lixo, o problema daqui é coisa daqui mesmo, eu queimo tudo aí, e aí não posso falar nada sobre o lixo ${ }^{S 6}$. O meu, é cavado aqui mesmo, porque meu terreno é grande eu queimo por aqui mesmo, nem jogo para lá, eu queimo aqui mesmo.

\section{Análise da questão 6}

Pode-se perceber, dos discursos, que o lixo é causa de inquietação para as pessoas que têm informações sobre sua problemática. É também uma possibilidade de geração de renda, a exemplo da reciclagem de papel, da compostagem, da confecção de brinquedos. O trabalho com o lixo impulsionou o desejo da construção de uma horta comunitária cuja produção seria utilizada na confecção dos doces "Sabores da Terra". Atualmente, algumas mulheres da comunidade fabricam doces em suas casas com a etiqueta "Sabores da Terra", atividade idealizada pela 
Associação. Percebe-se que a solução de um problema, no caso o lixo, durante o processo de sua resolução participativa, suscitou, nas pessoas, o desejo de discutir outras questões relacionadas ao seu modo de vida, à cidadania, à pobreza, entre outras que influenciam na qualidade de vida da comunidade.

Segundo a coordenadora do projeto, em resposta à pergunta aqui em análise:

"Acho que o lixo foi a nossa grande inspiração. Se não foi "a", foi uma "das". Pensar no lixo defronte da escola, aquela vergonha, aquele convívio, a cada mês ali no salão paroquial conviver com aquele lixo ao lado, aquilo é muito vergonhoso. É vergonhoso mas muito desafiador. Então, ao mesmo tempo em que ele nos provoca, ele nos desafia, esse foi um ponto central. Entender como aquele lixo foi gerado, ele não cai do céu, ele aparece na casa da gente, no local de trabalho da gente, enfim. Comecei a olhar o lixo de outra forma. Com um olhar de querer viver esse desafio e assim tem sido. Quem dera esse desafio transformar-se nesse sonho que sonhamos muito, o papel não ir para o lixão, o lixo orgânico ir para a compostagem e a gente começar a decompor cada coisa no seu lugar, esvaziando, chegando a um ponto em que só a "carcaça" mesmo é que será apanhada pelo caminhão que passa a cada sábado recolhendo o lixo ali na comunidade. Então estou me referindo à comunidade, mas o lixo faz parte da minha vida, do meu dia a dia e eu pude vivenciar isto dentro de minha casa. Fazendo o papel reciclado, fazendo a compostagem no fundo do quintal, passei por cada uma dessas etapas. Que possamos chegar a uma outra que seja mais possivel, mais viável e que a gente possa tirar o saber que ele oferece, como desafio. Então, continua sendo uma perseguição".

Percebe-se, nos discursos, que o lixo é considerado uma coisa boa devido à forma como é manuseado pelas pessoas atualmente, isto é, não traz problema ambiental e de saúde pública. O manuseio relatado é a compostagem doméstica do resíduo orgânico e muitos guardam o papel para encaminhar à oficina de papel da Associação.

O comportamento no descarte do lixo e a limpeza do ambiente escolar e dos quintais foram relatados. Em observações no local, percebe-se que os moradores que fazem compostagem doméstica, geralmente, têm horta e jardim. 
Nos discursos, não houve observações sobre o consumo, nem sobre o modelo de desenvolvimento na produção de descartáveis que, conseqüentemente, gera mais lixo. Em discursos anteriores, há menção sobre a responsabilidade das indústrias em relação aos seus produtos colocados no mercado. Também fazem a que, o lixo não era percebido no ambiente por possuir característica de lixo orgânico sofrendo, portanto, decomposição.

O discurso que se posiciona como não tendo nada a ver com o lixo está fundamentado no manuseio que é realizado, a queima do lixo. Esse é um hábito antigo observado em comunidades rurais. Atualmente, devido ao resíduo plástico encontrado no lixo, essa prática deve ser abandonada, pois gases produzidos na queima incompleta de tais resíduos liberam compostos que apresentam riscos à saúde da população quando inalados. Contudo, o lixo amontoado no terreno junto à escola, e próximo ao chafariz, chama a atenção pelo cheiro e pela possibilidade de contaminação da fonte de abastecimento de água. 


\subsubsection{Conclusão}

O projeto de Educação Ambiental desenvolvido no Arraial de São Francisco da Mombaça está inserido no contexto da chamada "sociedade sustentável". O projeto iniciou-se informalmente, por meio de conversas entre moradores locais e desencadeou várias ações, entre elas, a resolução do problema do lixo que, até então, era descartado a céu aberto em terrenos baldios.

As várias atividades do projeto proporcionaram mudanças significativas na localidade e nas pessoas da comunidade, pois a sua prática foi voltada para o desenvolvimento da sensibilidade, através da leitura crítica do contexto e da ação para a resolução de problemas locais. A prática também contempla os valores que a Agenda 21 promove, ou seja: parceria, solidariedade e a utilização de metodologias participativas.

O projeto foi construído, e as atividades realizadas de acordo com as demandas sentidas pelos membros da comunidade, apresentando características, como a formação de parcerias, tanto locais (escola, creche, associação), como externa ao Arraial (universidades, prefeitura, rede de leitura/comitê Salvador, Fundação ABRINQ). Essa rede de relações sociais permitiu uma permuta de saberes e de experiências durante o desenvolvimento das atividades do projeto, dando inclusive, um caráter interdisciplinar ao mesmo.

Outra característica que chamou a atenção foi a promoção da identidade comunitária, através do resgate da cultura local por meio da inclusão de pessoas idosas da comunidade nas atividades do projeto, as quais, ao interagirem com as novas gerações, contribuíram, com suas lembranças e experiências do passado para alimentar novas realizações.

Essas características, além de levar à participação, proporcionam a valorização pessoal dos indivíduos participantes do projeto, retiram-nos do isolamento. Essa valorização pessoal é representada pelos sentimentos expressos no discurso, cuja idéia central foi "o projeto mudou porque eu não sou a mesma pessoa". Muitas pessoas voltaram a estudar, foram despertados para a escrita, para a 
leitura de textos e contextos, e também declaram estar se relacionando melhor com os outros e difundindo o trabalho para outros locais.

Também foram citadas as mudanças ocorridas nas crianças da localidade, tanto em relação à visão sobre o ambiente, quanto ao modo de agir na escola, estando mais participativas e concentradas.

Em relação a mudanças ocorridas no Arraial destaca-se a limpeza dos quintais, nos quais, as pessoas envolvidas pelo projeto, organizaram o seu lixo realizando a compostagem doméstica e a segregação do papel, plástico e vidros. $\mathrm{O}$ adubo produzido na compostagem incentivou o surgimento de jardins e hortas. Essas novas atitudes podem levar a diminuição de doenças relacionadas a má disposição dos resíduos sólidos.

Deve-se destacar a importância os membros da comunidade, participantes do projeto, deram às atividades em torno de um projeto de interesse geral e com os benefícios compartilhados entre todos. As atividades do projeto para a resolução do problema local do lixo foram citadas como exemplo. Todas as etapas foram planejadas e executadas de forma a incluir o maior número de pessoas possível. A caracterização física dos resíduos sólidos é um exemplo: todos os moradores foram instigados a separar o lixo no dia da realização da atividade, sendo todos, previamente esclarecidos sobre os objetivos dessa ação. A concepção da praça, o plantio, a construção das baias para armazenamento dos resíduos sólidos foram executadas por moradores locais. Essa dinâmica de pensar e agir vai envolvendo a comunidade, motivando sua participação. Observa-se uma frustração em torno da interrupção da coleta seletiva na localidade, devido à falta de apoio da prefeitura, podendo levar a comunidade à percepção de que o atendimento das necessidades locais só acontecem através do Poder Público. Contudo, a idéia da retomada está presente nos discursos do sujeito coletivo.

A transformação do lixo em composto orgânico suscitou, nos moradores, a possibilidade da execução de uma horta, onde seria utilizado o composto orgânico na produção da matéria prima para uma fábrica de doces caseiros, com o objetivo de geração de renda. A reciclagem do papel também é citada como uma das possibilidades de geração de emprego e renda. A organização dos quintais, através 
do plantio de flores e de temperos, utilizando o composto orgânico, foi realizada conforme declarado nos discursos.

Na população local, há uma consciência de que a participação em reuniões e em atividades do projeto leva ao conhecimento sobre o mesmo. Para isto, é sugerido que a comunicação deve circular de forma mais eficiente na comunidade, bem como devem ser socializadas e divulgadas, a toda a população, as atividades programadas de interesse coletivo. A conquista de uma sede própria é um objetivo da Associação, pois, com isso, teriam um endereço, um referencial dentro da comunidade, e um local com mais segurança para abrigar os equipamentos da oficina de papel, já conquistados ao longo do projeto.

Está presente nos discursos a visão de que o apoio financeiro é importante para o andamento dos trabalhos, inclusive foi sugerido que as empresas que fabricam produtos embalados em plástico, vidro etc, deveriam ser as possíveis financiadoras dos projetos de gerenciamento dos resíduos sólidos.

As representações sobre o lixo em Mombaça podem ser sintetizadas como:

- A Representação do lixo que não é lixo: as pessoas têm a percepção de que no lixo tem "coisas boas" que podem ser transformadas. A idéia da reciclagem está presente. O termo "lixo" não representa essa idéia.

- Representação do lixo como fonte de renda: comercialização do adubo proveniente da compostagem e, também, sua utilização em horticultura. A reciclagem artesanal de papel e a confecção de brinquedos de sucata.

- Representação do lixo como uma inquietação: isto acontece quando há informação e conhecimento sobre os problemas ambientais e sanitários causado pelos resíduos sólidos.

- Representação do lixo que não é problema: essa representação acontece quando os sujeitos eliminam os seus resíduos no âmbito de suas residências com a prática da queima. 


\title{
4.3 PROGRAMA DE EDUCAÇÃO AMBIENTAL NO MUNICÍPIO DE MUCUGÊ
}

\author{
"Um morador antigo de Mucugê contou que, há 80 anos atrás, \\ existiu um homem conhecido como José Onça que, após ter \\ cortado um dos pés com um vidro passou a catar, até sua \\ morte, todos os cacos de vidro por onde passava e juntá-los em \\ pontos estratégicos da cidade. Um desses pontos é uma grande \\ pedra no cemitério. Neste período, a cidade de Mucugê \\ presenciou o início da coleta seletiva de um material inerte -o \\ vidro" (SEPLANTEC, 1999 p. 3).
}

\subsubsection{Caracterização do Município}

O termo "Mucugê" tem origem indígena e refere-se a uma fruta adocicada, leitosa e de sabor muito apreciado na região. A árvore, que pode ter até 10 metros de altura, cresce entre rochas, "daí o nome dado ao rio (Rio Mucugê) em cujas imediações cresce a referida planta. O mesmo nome foi dado à fazenda de criação de gado, Riachão de Mucugê, onde se desenvolveu o primeiro povoado - Mucugê da Chapada Diamantina, que mais tarde foi elevado à categoria de Vila com o nome de Santa Isabel de Paraguaçu" (MEDRADO 1998 p 7,8). Em 1890, a vila foi elevada à categoria de cidade com o nome de São João de Paraguaçu. A Lei Estadual n 1.226, de 1917, modificou o nome do município para Mucugê, o qual inclui os distritos de Guiné, Ibicoara e João Correia.

O município de Mucugê situa-se na região da Chapada Diamantina, ocupa uma área de $2491,8 \mathrm{~km}^{2}$, sendo 50\% inserida dentro do Parque Nacional da Chapada Diamantina, criado em 17 de setembro de 1985. O Parque é definido como "áreas extensas, dotadas de atributos excepcionais da natureza, de paisagem natural ou de valor científico ou histórico, objeto de preservação permanente, postas à disposição da população". Dentro do Parque, está em funcionamento um Programa Ambiental 
de preservação da "Sempre Viva", uma flor muito utilizada em arranjos e cuja extração de forma desordenada ameaçava sua extinção (Figura 15).

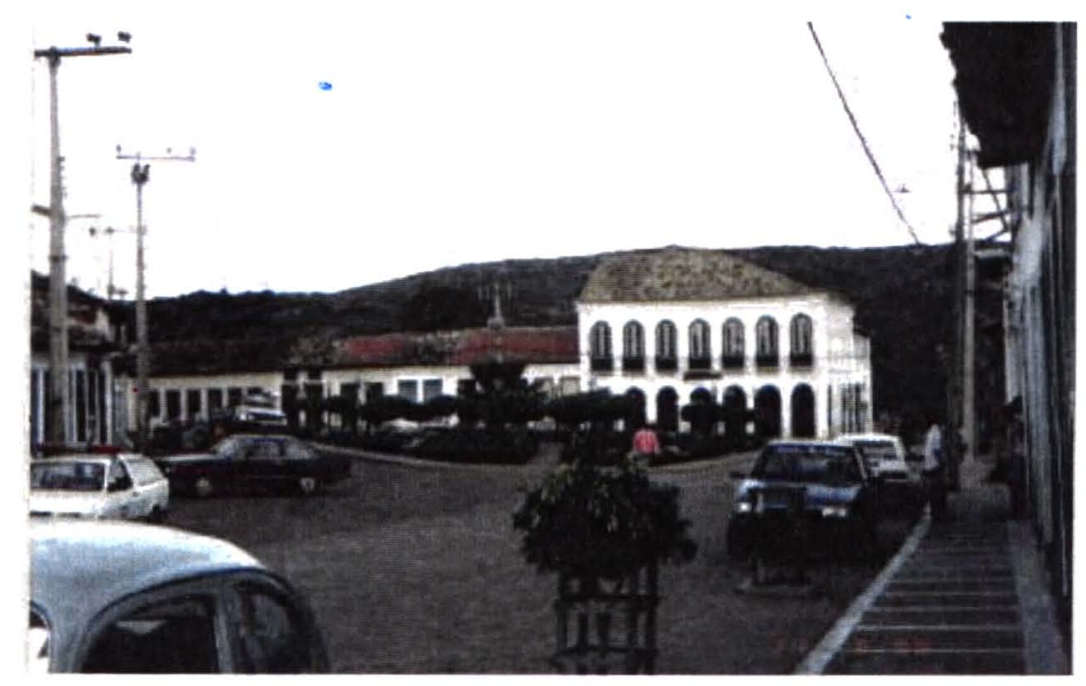

Figura 14 - Vista parcial da cidade de Mucugê - Bahia

$\mathrm{O}$ município de Mucugê pertence à Macro Região Geográfica e Administrativa de Seabra, à Região de Planejamento de Paraguaçu e à Região Econômica da Chapada Diamantina.

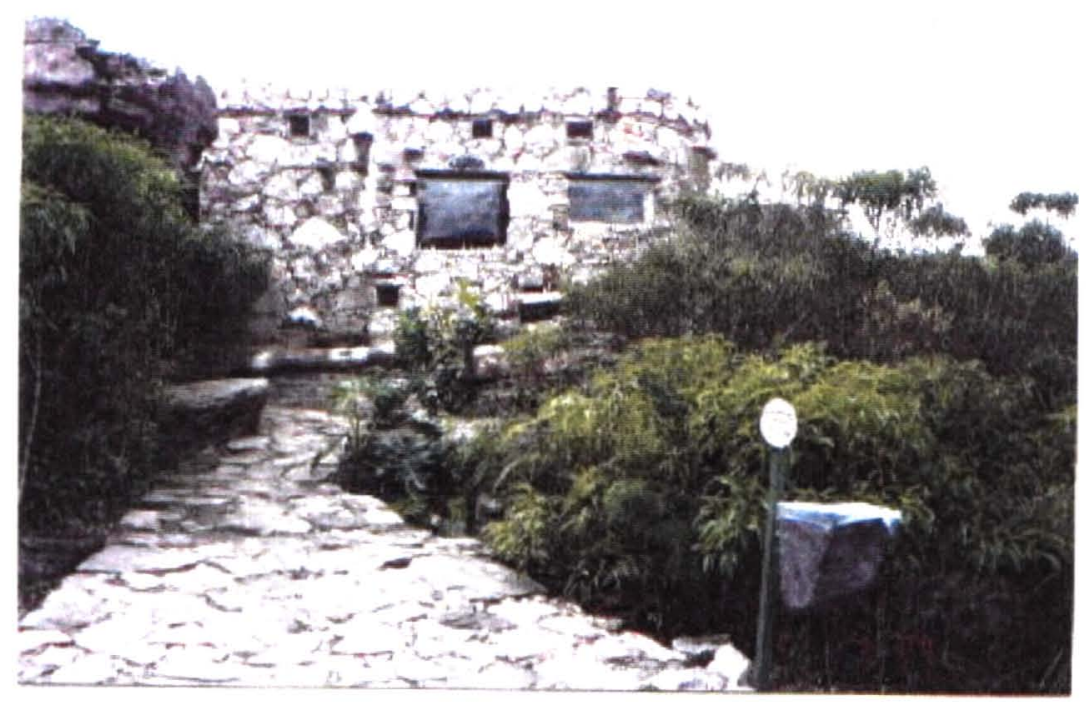

Figura 15 - Entrada do local da sede do Projeto Sempre Viva, situado no Parque Nacional da Chapada Diamantina. 
Mucugê possui população de 13.637 habitantes sendo que 9.989 habitantes $(73,2 \%)$ concentrados na zona rural e 3.048 habitantes $(26,8 \%)$ na zona urbana, apresentando uma densidade demográfica de $5,47 \mathrm{hab} / \mathrm{Km}^{2}$. Em relação ao sexo 6.442 habitantes são do sexo masculino e 6.596 habitantes do sexo feminino.

A sede do Município apresenta 827 domicílios. Destes, $98,8 \%$ estão ligados a rede geral de água e $1,2 \%$ são abastecidos por poços ou de outra forma. $O$ tratamento e disposição dos esgotos sanitários é realizado com a utilização de fossa séptica em 0,36\% dos domicílios; $44,74 \%$ dos domicílios estão ligados à rede geral de esgotamento sanitário ou pluvial. O restante, $51,03 \%$ dos domicílios despejam seu esgoto sanitário de outra forma (fossa rudimentar, vala, rio, lago).

O Município tem como atividade econômica, além do turismo devido à beleza natural exuberante, presente na região, a agricultura de tomate e café, entre outras. 


\subsubsection{Descrição do projeto}

Dois projetos foram realizados para implantar o gerenciamento dos resíduos sólidos urbanos no município de Mucugê: o projeto da Usina Simplificada de Reciclagem e Compostagem de Lixo e o projeto de Educação Ambiental.

\subsubsection{Coleta Seletiva e Usina Simplificada de Reciclagem e Compostagem de Lixo.}

Segundo a Secretária de Administração e Finanças da Prefeitura Municipal de Mucugê, gestão 1997/2000, no início da referida gestão, a forma de gerenciamento do lixo era coleta e transporte até um lixão. "O lixo coletado é destinado a um lixão, situado a $13 \mathrm{~km}$ da sede, depositado em valas, sendo, uma vez por semana, queimado, compactado e recoberto com material da própria escavação" (CAR/SEPLANTEC 1998a p.4). Preocupados com essa questão, a administração municipal resolveu implantar, no município, um aterro simplificado, "igual ao do município de Lençóis, projetado pelo Centro de Recursos Ambientais (CRA)". O aterro contava com três células e, na época da informação (21/09/2000), era utilizado somente em casos de emergência - quando havia grande fluxo de turistas, ou problemas na Central de Reciclagem e Compostagem do município.

Em 1998, a Prefeitura, com recursos da Companhia de Desenvolvimento e Ação Regional (CAR), adquiriu um veículo coletor, tipo Baú, para a realização da coleta. Também foi da CAR a idéia do Projeto e Implantação da Central de Reciclagem e Compostagem, justificada pelas "preocupações da CAR, enquanto instituição pública, com a estratégia de desenvolvimento sustentável para o Estado e, especificamente, para a Chapada Diamantina, o coração da Bahia" (SEPLANTEC 1998b). Segundo a Secretária, a escolha da instalação da Central em Mucugê deveuse ao fato de o município:

- receber muitos turistas;

- ter 50\% de sua área inserida no Parque Nacional da Chapada Diamantina;

- ter o veículo coletor. 
As razões da implantação da Usina em Mucugê, segundo a Técnica da CAR, coordenadora do projeto da Usina de Reciclagem e Compostagem de Mucugê, foram:

"A CAR, como uma empresa ligada ao governo do Estado da Bahia, tem, como ocupação, resolver questões básicas de saneamento, mais especificamente, a questão dos resíduos sólidos, por ser a que mais visivelmente chama atenção. Incomodava muito ao próprio secretário o fato de que, todas as vezes em que ele estava entrando nas cidades, principalmente de pequeno e médio porte, as prefeituras não estavam cuidando de seus lixos. Então veio esta preocupação e dentro do PRODUR (Programa de Desenvolvimento Urbano), que é um programa destinado a atender áreas urbanas, sendo lançado a parte de resíduos sólidos em convênio com prefeituras. A elaboração de planos de gestão de limpeza urbana é uma outra vertente. Com a gente, ficou, especificamente, trabalhar com municípios de pequeno porte e entrar com soluções alternativas. A CAR entra diretamente com o projeto, a implantação, o acompanhamento e com os recursos. Existiam duas cidades da Chapada Diamantina, Mucugê e Lençóis, às quais a CAR já tinha feito doação de um veículo coletor para o lixo. Nós fomos a essas duas cidades e analisamos em qual das duas seria mais interessante fazer o piloto. Por algumas questões, foi escolhida Mucugê.",

Para a elaboração do projeto, foi realizado o "Estudo para a Implantação de Usina Simplificada de Reciclagem e Compostagem do Lixo - município de Mucugê, BA", (SEPLANTEC, 1998b)", no qual, além do quadro atual da limpeza urbana do município, foram realizados os estudos gravimétricos. "Nós começamos no início de 1998 quando foi feita toda a parte de diagnóstico. Nós fizemos algumas viagens para conhecer usinas no estado de Minas e São Paulo e o início da construção foi em meados de 1999, sendo inaugurada no dia 7 de outubro de 1999" (Coordenadora do projeto).

$\mathrm{Na}$ avaliação da produção de resíduos foi considerada uma população fixa, na sede do município, de 3.600 habitantes e produção per capita de resíduos sólidos de $0,6 \mathrm{~kg} / \mathrm{dia}$. O quadro 11 resume as estimativas realizadas no estudo. 
Quadro 11 - Estimativa da produção de lixo em Mucugê, para os anos de 1998 e 2008.

\begin{tabular}{|c|ccc|ccc|}
\hline & \multicolumn{3}{|c|}{ População } & \multicolumn{3}{c|}{ Produção diária de lixo (kg) } \\
\cline { 2 - 7 } ANO & Fixa & Flutuante & Total & Fixa & Flutuante & Total \\
\hline 1998 & 3.600 & 1.800 & 5.400 & 2.160 & 1.080 & 3.240 \\
2008 & 5.920 & 2.960 & 8.880 & 3.552 & 1.776 & 5.328 \\
\hline
\end{tabular}

Fonte: SEPLANTEC, 1998a.

Conforme o estudo, a composição dos resíduos sólidos domiciliares encontrada foi:

- Matéria Orgânica - 69,80\%;

- Resíduo Inerte - 17,87\%;

- Rejeito - $12,33 \%$.

O estudo concluiu que, em face destes resultados, justifica-se a implantação da Usina Simplificada de Reciclagem e Compostagem de Lixo no município de Mucugê, BA. "A Usina foi escolhida como alternativa de destino final dos resíduos sólidos dentro da visão de gerenciamento integrado e utiliza tecnologias ambientalmente seguras e compatíveis com a realidade local" (SEPLANTEC, 1998a).

Com os dados obtidos, foram elaborados os projetos executivos e o treinamento dos recursos humanos necessários. Foi elaborado, também, o Projeto de Educação Ambiental, "pois o projeto não se encerra na instalação física da usina, mas promove, através do programa de Educação Ambiental nele inserido, a mudança dos conceitos de cidadania e preservação ambiental" (SEPLANTEC 1998b). Este projeto, elaborado pela CAR, envolveu em sua execução, a Secretaria Municipal de Saúde, através dos Agentes Comunitários de Saúde, a Secretaria Municipal de Educação e a Secretaria Municipal de Meio Ambiente.

O lançamento da coleta seletiva ocorreu no dia 5 de junho de 1999 e a implantação da Usina Simplificada de Reciclagem e Compostagem de Lixo, no dia 7 de outubro daquele mesmo ano. A partir dessa data, o sistema de gerenciamento de resíduos sólidos do município passou a envolver as etapas de coleta diferenciada e transporte até a usina (Figura 16). Na Usina Simplificada de Reciclagem e Compostagem de Lixo são realizadas as operações de: triagem dos materiais recicláveis, prensagem de lata, papel e plástico, armazenamento diferenciado do lixo 
chamado inerte (papel, vidro, plástico e metal) e a compostagem do resíduo orgânico (Figura 16 A,B,C,D e E). O rejeito que não é separado durante a catação é enterrado em valas localizadas no mesmo terreno da usina (Figura $16 \mathrm{~F}$ ).

A coleta do lixo orgânico tem frequiência diária e o lixo reciclável (inorgânico) é coletado duas vezes por semana, às segundas e quintas feiras. O lixo, após descarregado na usina, é colocado, manualmente, na mesa de catação fixa, onde dois funcionários fazem uma nova triagem, retirando, da massa do lixo os resíduos recicláveis (metais, vidro, papel, papelão e plástico), depositando-os, separadamente, em tonéis, sendo, 'após, prensado e armazenado para posterior comercialização.

Entre as atividades do programa de Educação Ambiental e a inauguração da Usina Simplificada de Reciclagem e Compostagem de Lixo houve uma defasagem de quatro meses devido à demora da Prefeitura Municipal em definir o gerente da usina, o que, operacionalmente, seria importante. Houve, também, demora na instalação dos pontos de entrega voluntária nos distritos. Devido a isto, no início da operação da usina, houve grande quantidade de rejeitos e o lixo orgânico previsto de $69,80 \%$ caiu para $22,75 \%$, havendo sobrecarga nas valas. Isto foi um indicador de que a população não estava respondendo à separação do seu lixo no domicílio como desejado e que a segregação na Usina não estava sendo realizada corretamente. Para minimizar o problema, foi realizada uma campanha na rádio local para divulgar as atribuições e as atividades necessárias à coleta seletiva. 

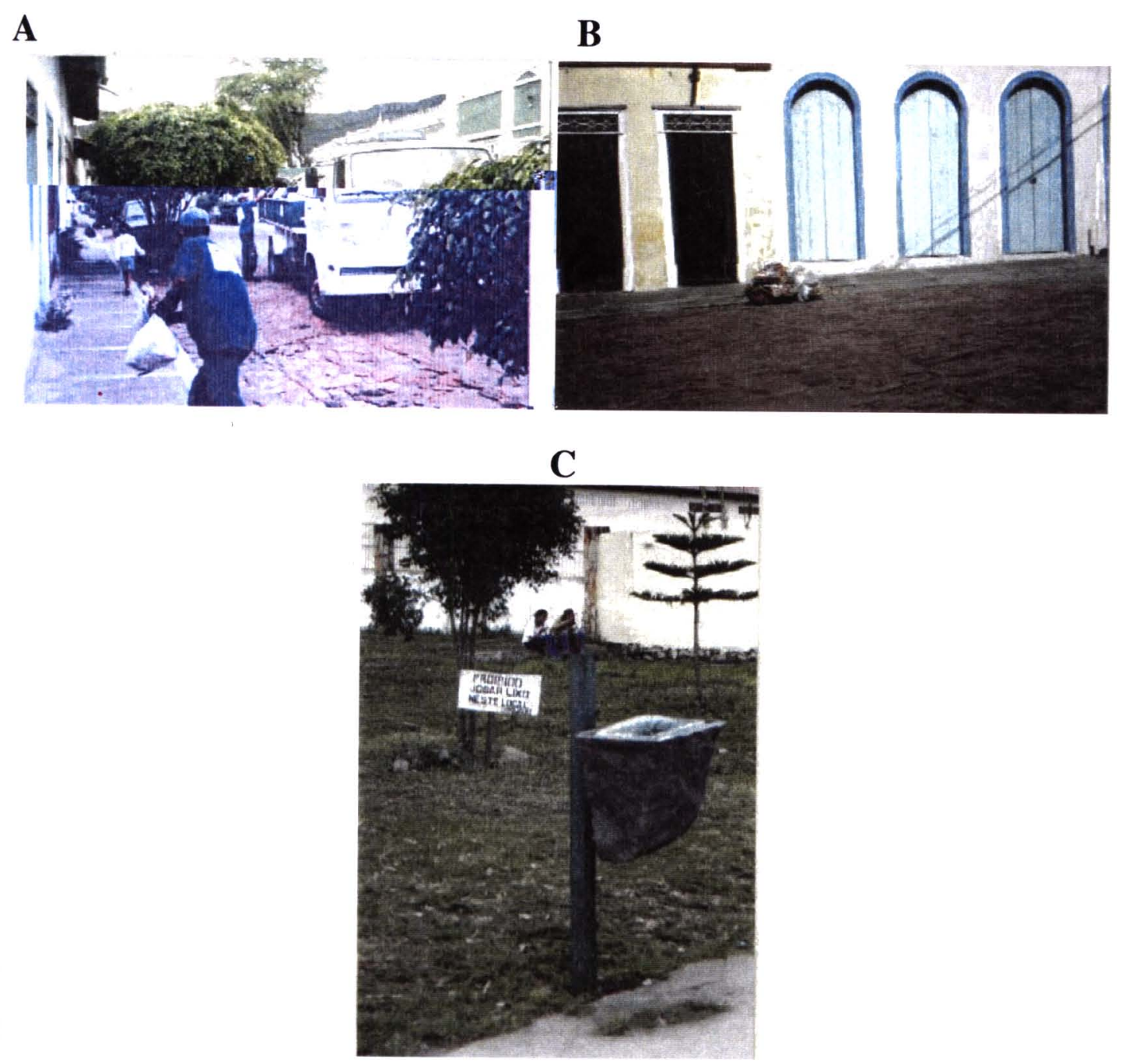

Figura 16 - Acondicionamento e coleta em Mucugê. (A) Coleta pública de resíduos. (B) Lixo segregado a espera da coleta pública. (C) Lixeira pública. 
A

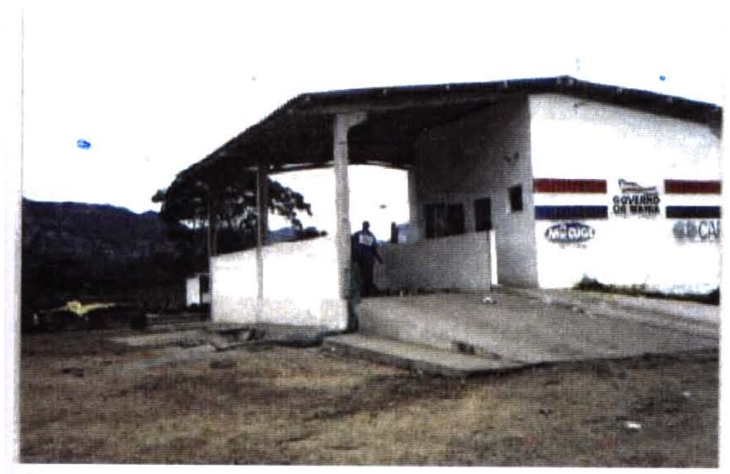

C

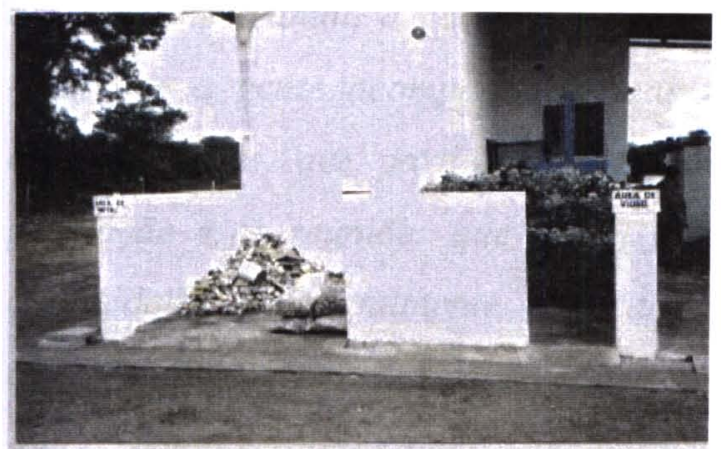

$\mathbf{E}$

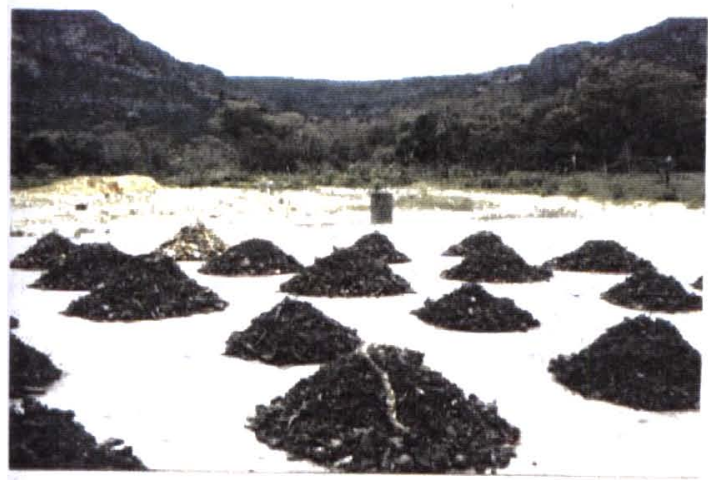

B

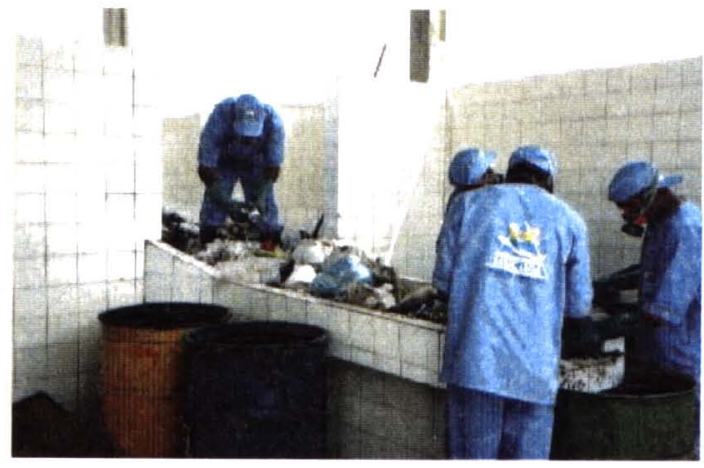

D

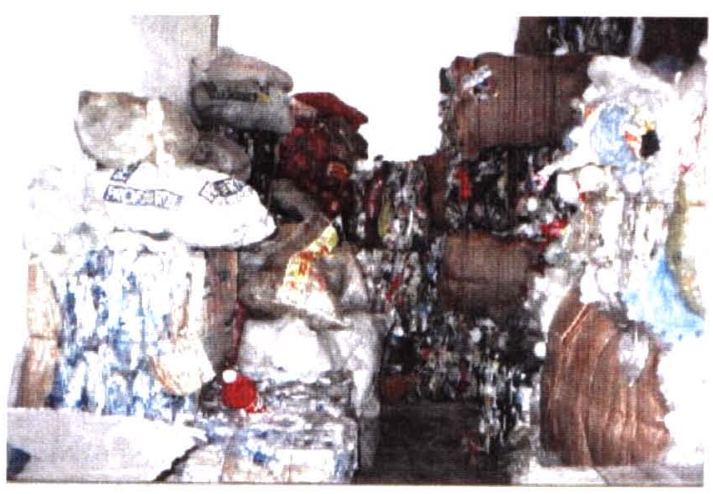

$\mathbf{F}$

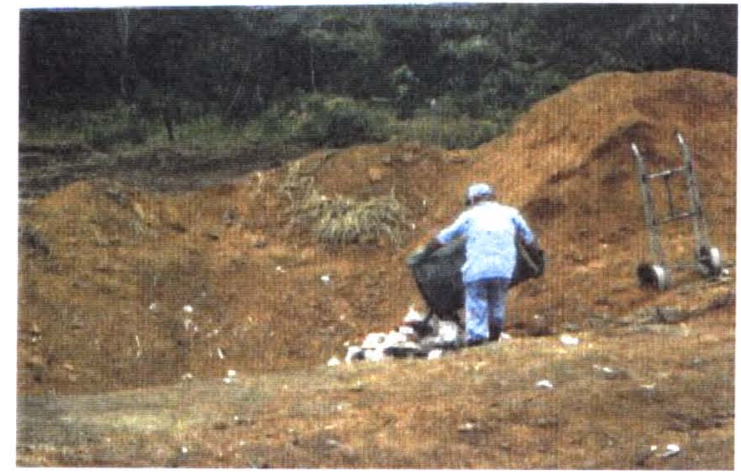

Figura 17 - Operações realizadas na Usina Simplificada de Reciclagem e Compostagem de Lixo de Mucugê. (A) Vista da Usina. (B) Triagem dos materiais recicláveis, (C) Baias para armazenamento de lata e vidro. (D) Resíduos papel e plástico prensado e armazenado. (E) Compostagem do resíduo orgânico. (F) Enterramento do rejeito (após o relançamento da usina). 


\subsubsection{Projeto de Educação Ambiental}

Paralelamente ao projeto da Usina Simplificada de Reciclagem e Compostagem foi desenvolvido o projeto de Educação Ambiental em Mucugê.

"Eu tenho ciência de que uma coisa não é independente da outra, um trabalho técnico operacional não entra, se a questão educacional não estiver trabalhada, se a comunidade não estiver envolvida, isto está bem claro. Como a minha parte é mais técnica e operacional, nós contratamos uma consultoria para trabalhar a questão ambiental e foram envolvidos três profissionais para trabalhar, basicamente, a questão educacional, a conscientização, esse trabalho de Educação Ambiental. $E$ claro que a gente acompanhava, mas não amilide. Então, foram desenvolvidas algumas idéias, que partiram do seguinte: primeiro, um contato inicial com a população e as reuniões que foram feitas, onde participaram todas as fatias da comunidade, principalmente focando o estudante. Depois desses encontros, começou-se a levar informação sobre os resíduos sólidos. Informações específicas sobre resíduos sólidos dentro da cidade de Mucugê, o que se pretendia fazer, a importância da participação da comunidade neste projeto, e entramos com outra fase, que foi a fase dos mutirões. Fizemos um "faxinão", um mutirão ecológico. Houve uma série de questões para estimular a população estudantil, alguns concursos como a melhor poesia, a melhor frase, o melhor objeto construído com o lixo reciclável e a gente premiou esses estudantes. Foi muito interessante, a população participou muito. Independente de a gente estar fazendo este trabalho já existia uma história em Mucugê: há dois anos antes, mais ou menos em 96, começou-se a trabalhar a questão da consciência ambiental por conta do projeto Sempre Viva. Então, isto foi um dos pontos que fez com que a gente focasse Mucugê como piloto. Para a população, já era familiar a preservação e dessa consciência ecológica, facilitando o trabalho." (Coordenadora geral do projeto)

Os objetivos do Projeto de Educação Ambiental proposto pela CAR foram:

1. Envolver a população no processo de construção de alternativas de solução para os impactos causados pelo lixo, em relação ao meio ambiente. 
2. Criar as bases para a implantação da Usina Simplificada de Reciclagem e Compostagem de Lixo.

3. Melhorar a qualidade de vida da população.

A clientela atingida pelo projeto foi a comunidade da sede do município e dos Distritos de João Correia e Guiné, Fazenda Horácionópolis, Fazenda Sol do Paraguaçu e Povoado do Brejo de Cima.

A metodologia proposta no projeto consta de duas etapas. A primeira, objetiva, através de palestras, informar e sensibilizar: a) lideranças da cidade, vereadores e pessoas ligadas às Secretarias Municipais de Saúde, Educação, Administração, Finanças e Obras, diretores e professores, Associações de bairros, Igrejas e outros grupos; b) Moradores da sede e alunos das escola públicas; c) Moradores dos Distritos, Fazendas e Povoados vizinhos. As palestras visaram repassar informações sobre o programa a ser implantado, sobre o lixo versus saúde pública e sobre a proteção do meio ambiente. Também deveriam ser abordadas questões referentes às conseqüências positivas do tratamento adequado do lixo, como incremento do turismo e a conseqüente melhoria da qualidade de vida da população. Questões sobre redução, reutilização, reciclagem e coleta seletiva deveriam ser enfocadas. Seriam também repassadas à população, nessa atividade, informações sobre o Projeto da Usina Simplificada de Reciclagem e Compostagem do Lixo e sobre a segunda etapa do projeto de Educação Ambiental.

A segunda etapa propôs ações de sensibilização através do concurso "Preserve o Meio Ambiente" e do "Mutirão de Limpeza" (Dia da Faxina). Os concursos previstos foram de melhor frase, melhor cartaz para afixar em pontos turísticos, melhor reutilização de sucata e melhor canção, sendo abertos à participação de todos os moradores da região.

O "Dia da Faxina" foi programado para ser realizado em dois dias. No primeiro, a faxina seria efetuada nas residências, onde os moradores deveriam "expurgar entulhos e objetos inservíveis de grande e pequeno porte". No segundo, foram propostos, no projeto, três atividades: a primeira, um mutirão de limpeza em pontos turísticos da sede do município (Cruzeiro, Rio Mucugê, Rio Paraguaçu, Rio Preto e Lapa do Caboclo). A segunda atividade seria uma simulação da coleta seletiva e a terceira, a realização de uma festa para a premiação dos vencedores do 
concurso "Preserve o Meio Ambiente" e a instalação oficial do Projeto "Mucugê de Cara Nova". A escola local foi a grande parceira no encaminhamento dessas atividades.

"A nossa é a línica escola de $5^{a}$ a $8^{a}$ série de ensino fundamental e de $1^{\circ}$ a $3^{\circ}$ ano e de ensino médio da cidade. A escola, como em todo interior, todo mundo tem um parente dentro da escola, um filho, um neto, um sobrinho, então a melhor forma que se tem de levar educação para dentro desses lares é educando as próprias crianças. Foi aí que a gente entrou como parceiro. Fomos convidados para fazer parte do projeto e abraçamos a causa. A gente mostrou para as pessoas, começamos a fazer campanhas, fizemos mutirões de limpeza na cidade logo na inauguração da usina. O nosso papel, o nosso trabalho foi esse, fazer um mutirão de limpeza. Nós limpamos todos os pontos da cidade porque os becos, leitos dos rios que passam em torno da cidade, a pista de automóvel, a rodovia também, as laterais são sujas. Então nós, numa distância de mais ou menos $6 \mathrm{~km}$ em cada uma das entradas da cidade, fomos até lá com as equipes, com os alunos todos e com a comunidade catando esse lixo. Se não me engano, nós recolhemos com as crianças naquele dia do mutirão, o dia $D$ que a gente chamou, conseguimos trazer aqui para a praça, deixando amontoado ali no meio da praça de Mucugê, cerca de 4 a 5 mil quilos de lixo.. Isto aí foi um susto, era um lixo que até aquele momento era quase invisível. As pessoas passavam e pensavam que não tinha, que a cidade era limpa, e no entanto a gente pôde constatar a quantidade de coisas que uma pessoa joga: uma latinha na beira da estrada, um maço de cigarro, uma coisa assim e isso vai aglomerando. Cada um joga um pouquinho e dá nisso. A gente conseguiu fazer isto e despertar. Tiramos fotos, foi filmado no dia, foi um grande evento. Logo em seguida, o carro do lixo já ia levando e a gente já ia colhendo separadamente, isso só foi o lixo reciclável o material que não se consome e esse lixo foi todo para a usina para sero primeiro lixo separado, foi esse o lixo que a gente conseguiu pegar. A gente entrou de corpo e alma neste projeto. A partir disto, tivemos apoio da prefeitura também em todos os momentos em que íamos trabalhar num projeto relacionado dentro da escola. A prefeitura sempre apoiava porque a nossa escola é do Estado e fica meio longe da Secretaria de Educação". (Coordenador do projeto na escola). 
Os resultados esperados e descritos no projeto eram que, "ao final do Programa, a clientela deveria apresentar uma nova mentalidade ecológica e crítica para reconhecer as distorções e erros praticados ao longo do tempo, reduzindo o volume de lixo produzido, participando ativamente da coleta seletiva, preservando, assim, o meio ambiente e tornando-se cada vez mais cidadã, contribuidora de seus deveres".

A avaliação dos resultados do trabalho, sugerida no projeto, seria "estabelecimento de comparativos da situação atual, na época com a posterior, utilizando como parâmetros a quantidade de lixo produzido, adesão à coleta seletiva, descarte do lixo, identificação de doenças provocadas por tratamento inadequado do lixo, dentre outros". A responsabilidade por essa avaliação "deveria ser feita pelos profissionais responsáveis pelo projeto técnico".

\subsubsection{Avaliação pela CAR do Projeto de Educação Ambiental desenvolvido em Mucugê}

A avaliação realizada pela equipe da CAR apoiou-se em um questionário aplicado ao público envolvido nas palestras, durante o período de 22 a 26 de março de 1999. Foram preenchidos 300 formulários que continham seis perguntas objetivas e uma questão aberta para comentários e sugestões (CAR, 1999).

$\mathrm{Na}$ análise dos resultados, observou-se que todas as pessoas gostaram da programação realizada e $89,3 \%$ aprovaram o conteúdo e a duração das atividades. Perguntados se o evento ampliou seus conhecimentos, $99 \%$ responderam que sim. A maioria $(91 \%)$ respondeu satisfatoriamente à pergunta se a metodologia utilizada estimulou a participação do grupo: $3,7 \%$ responderam que não e $5,3 \%$ não responderam a questão. Quanto à pergunta para avaliar o desempenho dos facilitadores, $99 \%$ responderam que o desempenho destes possibilitou a compreensão dos assuntos tratados e somente uma pessoa não respondeu a essa questão. A última pergunta objetiva perguntar se as atividades desenvolvidas mobilizaram seu interesse e envolvimento nas questões relacionadas ao meio ambiente: $98 \%$ responderam sim, $0,7 \%$ responderam não e $1,3 \%$ não responderam. 
Nessa avaliação, 21 pessoas fizeram algum tipo de comentário e/ou sugestão. Os comentários, em geral, foram positivos "gostei e foi esclarecedor. Para todos nós da comunidade, a educação ambiental é muito importante, é bom para a educação e para a orientação da comunidade, abre a mente das pessoas, ajudou a conhecer o meio ambiente e deu informações sobre o lixo que não conhecíamos. Evita doenças, ajuda o ambiente, diminui a quantidade de lixo a céu aberto". Algumas pessoas vislumbram o projeto como fator positivo para o município: "o projeto está sendo muito bom para Mucugê, ajudará no desenvolvimento da comunidade em vários setores, vai gerar empregos para muitas pessoas e trará mais visitantes para o lugar. Alguém lembrou que é importante que o projeto "não fique só na teoria".

Dentre as sugestões apresentadas, além de sugerir que o projeto fosse colocado em prática o mais rápido possível e que atendesse a outros municípios da região, observou-se a preocupação com os coletores públicos de lixo e com em relação à divulgação e à sensibilização da população. "Aproveitar as feiras semanais na sede para colocar coletores seletivos no sentido de sensibilizar a população quanto à necessidade e aos benefícios do projeto, colocar mais lixeiras nas escolas, nas ruas e placas nos pontos turísticos" e, também, "mudanças de hábitos ocorrem através de muita divulgação permanente, pois demora muito tempo para acontecer. Utilizar o rádio e propagandas para mostrar o projeto para a população".

Houve também sugestões em relação aos distritos no sentido de que "todo o distrito deve reciclar o lixo" e que houvesse um retorno financeiro para o local "pagar um percentual para os distritos vizinhos reciclarem seu lixo".

No relatório de avaliação, também estão colocados comentários dos técnicos da CAR. Observou-se neles que não há considerações sobre as atividades de Educação Ambiental realizadas. Além de comentários sobre o potencial turístico devido à natureza local, há observações sobre a avidez da população em receber novos conhecimentos e que, por ser o município de pequeno porte e contar com "valores sociais não contaminados", tais aspectos favorecem positivamente os resultados do programa. 


\subsection{4 - Materiais de sensibilização e informação sobre a coleta seletiva}

Resgataram-se dois folhetos (folder) utilizados nas campanhas de sensibilização e informação: o primeiro, com o título "Mucugê na era da reciclagem. Garimpando o lixo", utilizado no lançamento da usina e o segundo, "Separe o seu lixo vamos reciclar - programa de coleta seletiva em Mucugê" distribuídos no relançamento da usina. Também, resgatou-se, através de um morador local, o jingle veiculado pelo carro de som ao circular pelas ruas da sede do município.

Basicamente, o conteúdo de ambos os folhetos foi:

1. Normativo: com informações sobre a coleta seletiva, a forma de segregação dos resíduos e o destino destes.

- Definição da coleta seletiva: definida como a coleta realizada em dias e horários diferentes, para o lixo orgânico e para o lixo inorgânico. Os horários de coleta são explicitados.

- Como separar o lixo: nesse item é explicado que o lixo deve ser separado em sacos diferentes, de acordo com suas características (orgânico e inorgânico), bem como a forma de colocá-los no interior dos sacos, para evitar acidentes com o pessoal da coleta e para melhor aproveitamento dos materiais inorgânicos, pela lavagem dos vasilhames antes do descarte.

No segundo folder, houve uma alteração quanto à forma de segregação do lixo. Foi solicitado aos moradores que, além da segregação do orgânico e do inorgânico, houvesse a separação, em outro saco, do resíduo chamado de rejeito (papel higiênico, guardanapo, absorvente, fralda descartável, ponta de cigarro, chiclete, papel carbono, isopor, espumas e trapos).

- O manuseio do lixo na usina: nesse item, são explicitadas as formas de processamento dos resíduos sólidos segregados pelos moradores. Prensagem, enfardamento e armazenagem para a comercialização dos resíduos inorgânicos e a compostagem do resíduo orgânico.

2. Não-normativos: são os conteúdos nos quais se observam solicitações à comunidade para colaborarem com o projeto. 
Do folheto: "Mucugê na era da reciclagem. Garimpando o lixo" encontram-se os seguintes textos:

- "O que você fizer pelo ambiente estará fazendo por você. Colabore: reduzindo as coisas que você joga fora; reutilizando os objetos; não jogando lixo nas ruas, nos terrenos baldios, rios, etc; colocando o lixo ensacado; separando o lixo".

- "Sua participação é muito importante para o sucesso desse projeto. Colabore, separando o material reciclável, antes de colocar o lixo para a coleta. Desta forma você estará exercendo sua cidadania e também preservando a natureza e sua cidade".

O folheto "Separe o seu lixo vamos reciclar - programa de coleta seletiva em Mucugê" distribuído à comunidade durante o relançamento da usina inicia, explicando que está sendo relançada a coleta seletiva com o "objetivo de reaproveitar ao máximo o lixo produzido, preservando a natureza". Apresenta também o seguinte texto "não normativo":

- "Como você deve contribuir: separando o lixo em sua residência ou estabelecimento comercial ou público, obedecendo a classificação, dias e horário de coleta. Assim, você estará sendo responsável pelo que produz, contribuindo com sua comunidade e cuidando da natureza".

Nesse folheto, não foram incluídos conteúdos sobre a minimização dos resíduos sólidos. Contudo, é registrado um convite para que a comunidade visite a usina para observar a contribuição de cada um no processo de gerenciamento.

Os folhetos distribuídos à comunidade de Mucugê têm caráter basicamente normativo, isto é, informam como a população poderia participar do gerenciamento dos resíduos sólidos urbanos proposto com a instalação da Usina Simplificada de Reciclagem e Compostagem.

Nos conteúdos "não normativos" não é explorada a problemática dos resíduos sólidos, tais como: as conseqüências, para a saúde e para o ambiente, do lixo jogado em terrenos baldios, rios e na rua, e a importância da minimização dos resíduos para o ambiente. O título do primeiro folder - "Mucugê na era da reciclagem" - também pode sugerir a "riqueza do lixo" ao associá-lo com o garimpo e, a reciclagem, como solução para a questão do lixo. 
Como o material impresso utilizado nas campanhas de sensibilização da UEFS, e os utilizado nos folhetos distribuídos em Mucugê não apresentaram uma organização textual "ideal": contextualização histórica e social do discurso; abordagem dos efeitos provocados por decisões e atitudes; reflexão que leve a uma consciência do problema; e apresentação de propostas e soluções” (TRAJBER e MANZOCHI, 1996 p. 32).

O jingle veiculado pelo carro de som em Mucugê foi elaborado com o seguinte texto:

"Só bote o lixo na porta, pertinho da hora do caminhão passar. Sua rua mais cheirosa e mais bonita, fica mais fácil da prefeitura trabalhar. Pare para pensar: a prefeitura acaba com o lixo se você colaborar".

No texto, observa-se um incentivo para a colocação do lixo na porta, respeitando os horários de coleta. Isto é importante para manter a limpeza da cidade ao se evitar que os sacos acondicionadores de lixo sejam depredados por animais. Contudo, a parte final do texto sugere que o problema do lixo termina com a sua coleta, eximindo a população de sua responsabilidade em relação ao destino que é dado após a essa etapa.

\subsubsection{Indicadores de geração de resíduos sólidos urbanos em Mucugê}

Os dados da produção de lixo em Mucugê e os segregados na Usina são, diariamente, anotados em planilhas específicas. Para se ter uma idéia da evolução da produção do lixo em Mucugê, tomou-se como exemplo o mês de abril dos anos de 2000 a 2002. O mês de abril foi escolhido, para essa ilustração, por ser o mês posterior à reativação da usina, obtendo-se, portanto, uma série de dados. Esses dados estão descritos na tabela 9.

Considerando-se a geração total de Resíduos Sólidos do mês de abril do período de 2000 a 2002, os dados e a população urbana de Mucugê, foi calculada a geração per capita média diária, durante os anos de 2000 a 2002, valores apresentados na tabela 10. Os dados populacionais foram estimados considerando-se uma taxa de crescimento médio geométrico da população urbana de 4,5\% (SEI 
2002). A tabela 11 mostra o acréscimo da geração de lixo em Mucugê e do valor do per capita médio diário durante o período estudado.

Observando-se os dados relacionados na tabela 11, verifica-se que a geração mensal de lixo em Mucugê, tomando-se por base o mês de abril, teve um incremento de $15,9 \%$, entre os anos de 2000 para 2001 e de 15,3\% entre os anos de 2001 e 2002. O valor do incremento do per capita diário foi de 14,3\% (entre 2000 e 2001) e de $8,3 \%$ (entre 2001 e 2002).

Observa-se, também, que a fração orgânica, dentre os resíduos segregados e possíveis de serem valorizados, apresenta-se em maior quantidade, variando de $40 \%$ a $54,7 \%$. Esses valores são inferiores aos encontrados no estudo inicial para a implantação da usina $(69,8 \%)$, como também aos de localidades do interior da Bahia, conforme ilustrado no gráfico 1. Da mesma forma, o rejeito que foi estimado em $12,33 \%$ no estudo inicial é bem abaixo dos valores encontrados nos meses estudados e descritos na tabela 9, (32,9 a 52,4\%). Este quadro sugere que a segregação, tanto por parte dos moradores, como pelos funcionários da usina, não está sendo realizada de forma satisfatória (Figura 18).

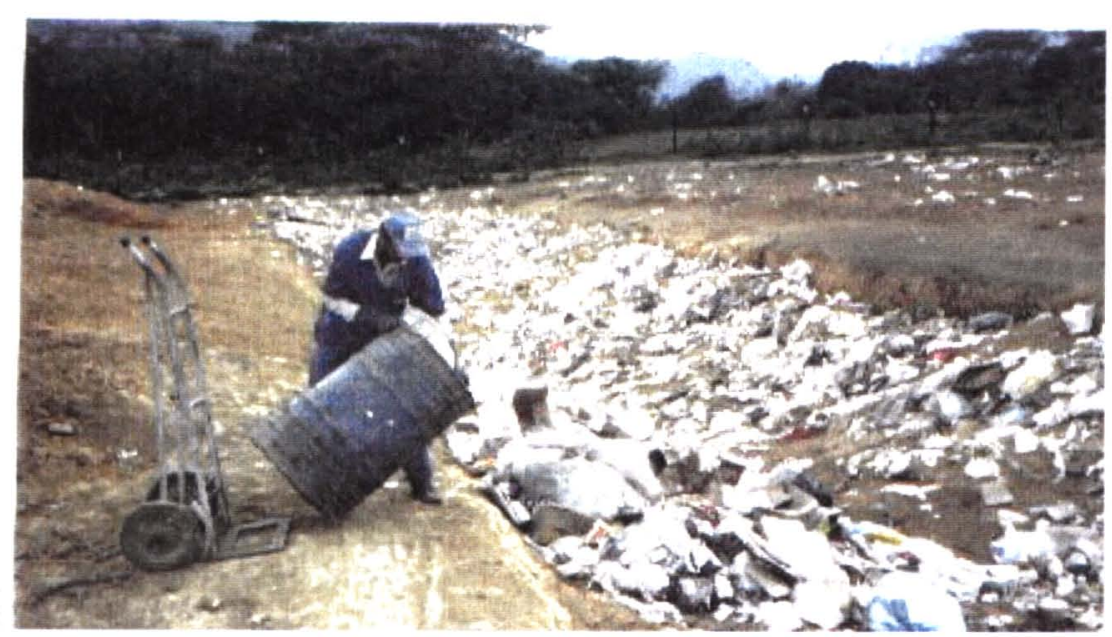

Figura 18 - Descarga do rejeito gerado na usina, observando-se uma quantidade significativa de resíduo reciclável sendo enterrado. 
Tabela 9 - Resíduo segregado na Usina de Reciclagem e Compostagem de Mucugê proveniente da coleta pública municipal, durante os meses de abril de 2000, 2001 e 2002.

\begin{tabular}{|c|c|c|c|c|c|c|}
\hline \multirow{4}{*}{$\begin{array}{l}\text { Tipo de } \\
\text { Resíduo }\end{array}$} & \multicolumn{6}{|c|}{$M \hat{E} S / A N O$} \\
\hline & \multicolumn{2}{|c|}{ Abril 2000} & \multicolumn{2}{|c|}{ Abril 2001} & \multicolumn{2}{|c|}{ Abril 2002} \\
\hline & \multicolumn{2}{|c|}{ Quantidade } & \multicolumn{2}{|c|}{ Quantidade } & \multicolumn{2}{|c|}{ Quantidade } \\
\hline & $\mathrm{kg}$ & $\%$ & $\mathrm{~kg}$ & $\%$ & $\mathrm{~kg}$ & $\%$ \\
\hline Orgânico & 8.479 & 40,0 & 13.459 & 54,7 & 14.047 & 49,5 \\
\hline Poda & n.q & - & n.q & - & 178 & 0,6 \\
\hline Papel/Papelão & 491 & 2,3 & 831 & 3,4 & 938 & 3,3 \\
\hline Vidro & 126 & 0,6 & 225 & 0,9 & 195 & 0,7 \\
\hline Alumínio & 60 & 0,3 & 61 & 0,3 & 36 & 0,2 \\
\hline Ferro & 175 & 0,8 & 524 & 2,1 & 484 & 1,7 \\
\hline Plástico & 196 & 0,9 & 600 & 2,4 & 775 & 2,7 \\
\hline Hospitalar & 580 & 2,7 & 809 & 3,3 & 860 & 3,0 \\
\hline Rejeito & 11.112 & 52,4 & 8.093 & 32,9 & 10.848 & 38,3 \\
\hline TOTAL & 21.219 & 100 & 24.602 & 100 & 28.361 & 100 \\
\hline
\end{tabular}
n.q - não quantificado

Tabela10 - Evolução per capita médio diário da geração de lixo em Mucugê.

\begin{tabular}{c|c|c|c}
\hline \multirow{2}{*}{ Indicador } & \multicolumn{3}{|c}{ ANO } \\
\cline { 2 - 4 } & $\mathbf{2 0 0 0}$ & $\mathbf{2 0 0 1}$ & $\mathbf{2 0 0 2}$ \\
\hline População urbana & 3.317 & 3.466 & 3.622 \\
\hline Per capita (kg/hab.dia) & 0,21 & 0,24 & 0,26 \\
\hline
\end{tabular}

Tabela 11 - Acréscimo anual da geração de lixo em Mucugê e do valor do per capita médio diário durante os anos de 2000 a 2002.

\begin{tabular}{c|c|c|c}
\hline \multirow{2}{*}{ Indicador } & \multicolumn{3}{|c}{ ANO } \\
\cline { 2 - 4 } & $\mathbf{2 0 0 0}$ & $\mathbf{2 0 0 1}$ & $\mathbf{2 0 0 2}$ \\
\hline $\begin{array}{c}\text { Acréscimo na geração } \\
\text { do mês de abril (\%) }\end{array}$ & - & 15,9 & 15,3 \\
\hline $\begin{array}{c}\text { Acréscimo no valor do } \\
\text { per capita }(\%)\end{array}$ & - & 14,3 & 8,3 \\
\hline
\end{tabular}




\subsubsection{Relançamento do projeto}

A descontinuidade administrativa presente em muitos municípios da Bahia, da qual Mucugê não foi exceção, fez com que a Usina Simplificada de Reciclagem e Compostagem parasse de funcionar no final do ano 2001. "Houve a troca de prefeito na cidade de Mucugê e isto fez com que o funcionamento da usina sofresse uma interrupção. Ela ficou parada por cerca de 4 meses e depois da nova prefeita, nós retornamos e estamos relançando, agora, o projeto" (Coordenadora geral do projeto).

Este fato também pode ser um indicativo de que o programa de educação ambiental não conseguiu construir o "desejo do novo" na comunidade, isto é, aquilo que era esperado pelos técnicos da CAR e da prefeitura naquele momento. SPOSSATI, comentando sobre a descontinuidade de projetos na prefeitura de São Paulo, observa que é fundamental, na atuação em comunidade, a construção da subjetividade coletiva pois, quando esse processo não ocorre, a alteração pretendida não alcança o imaginário coletivo, o desejo da sociedade e, conseqüentemente, tornase descartável"(SPOSSATI 2001, p. 25).

Foram as seguintes as dificuldades encontradas ao longo da operação da Usina Simplificada de Reciclagem e Compostagem, segundo a coordenadora geral do projeto:

"A primeira delas, quando se implanta um projeto que tem toda uma base científica, a gente acha que aquilo vai acontecer de acordo com o previsto. E não deixamos espaço para o imprevisível. Então, assim nesta falta de espaço aconteceram algumas questões de ordem de gestão desse projeto que fizeram com que ele tomasse um rumo um pouco diferenciado da concepção. A CAR tem como objetivo, em todos os projetos em que ela se envolve, financiar, construir e entregar. Ela não acompanha, ela não executa. É uma característica da empresa. Nós demos acompanhamento a este projeto durante seis meses, contratamos uma bióloga para acompanhar a compostagem; essa bióloga foi depois contratada mais seis meses pela prefeitura mas, mesmo assim, faltou o gerenciamento da usina por parte da Prefeitura Municipal de Mucugê. Não houve uma preocupação de destinar um profissional que pudesse, de fato, acompanhar aquilo ali, um projeto daquela 
importância. E também, por questões de ordem política, inclusive, foram colocadas pessoas que não tinham perfil para este tipo de acompanhamento e a gente não conseguia monitorar da forma que deveria ser monitorado. Nós, apesar de termos implantado vários formulários de controle, não recebiamos as informações, o que fazia com que não tivéssemos material para trabalhar. E como a gente não tinha deixado espaço para esta questão e como a gente tinha pensado, calculado dentro do que foi projetado, iria continuar a funcionar dentro daquilo que foi projetado. Mas isso não aconteceu".

A Usina voltou a funcionar no dia 13 de março de 2002. Para isto, os técnicos da CAR realizaram, no período de 27 a 30 de novembro de 2001, um "Programa de Mobilização e Aprendizagem para a Coleta Seletiva de Mucugê. Relançamento" (CAR, 2001). Esse programa foi realizado por uma equipe de profissionais ligados diretamente à CAR.

O objetivo do Programa foi capacitar pessoas sobre a importância da coleta seletiva em todos os locais do município, para o funcionamento da usina, e conscientizá-las no sentido de "valorizar a natureza, em vez de destruí-la". A proposta foi trabalhar, individualmente, grupos constituídos de donas de casa e domésticas, comerciantes e donos de pousadas, pessoal ligado à área de saúde, funcionários da limpeza urbana e estudantes. A ênfase da atividade foi "trabalhar a auto-estima da comunidade, levando-a a repensar suas responsabilidades para atingir um objetivo comum", através de oficinas de aprendizagem, dinâmicas de grupo, dramatização e partilhas de vivência (CAR, 2001).

Não houve avaliação por parte dos responsáveis sobre as atividades realizadas. Segundo informação da coordenadora do programa de Mobilização e Aprendizagem, a idéia é que os grupos capacitados formem uma rede local para levar adiante o programa.

“....Então, desta vez, no relançamento nós tentamos fazer um trabalho em que a comunidade toda fosse envolvida em um trabalho de autoconhecimento. Não só a questão do lixo, mas o que elas estão fazendo com os "lixos internos". Teve um módulo em que nós trabalhamos com os "lixos internos", foi um trabalho bonito, a gente trabalhou com uma rede, a gente chamou de rede de mobilização da cidade de Mucugê. Envolvemos todas as Secretarias, todos os comerciantes, todos os feirantes, 
guias turísticos, mestres, enfermeiras, escolas, varredores, todos os segmentos da comunidade de Mucugê. Nós formamos grupos independentes, por exemplo, os comerciantes, as mães, donas de casa, as domésticas, e trabalhávamos aquele grupo sobre auto-conhecimento, integração e, depois, a questão do lixo. A parte técnica era dada por outra pessoa - a questão da coleta, da separação, da compostagem, como todo esse processo era feito - e trabalhamos com vídeos, com cartilhas, em grupo, com desenhos, muisica, dramatização. Foi um trabalho que envolveu toda a cidade. Depois a gente começou a interagir esses grupos, por exemplo: a varredora falava com os estudantes, então eles começaram a ver aquele papel, como elas estavam trabalhando, o que sentiam, como estava a auto-estima delas, pois o pessoal que trabalha com o lixo tem uma auto-estima muito baixa e as pessoas não estão nem ai, passam e continuam jogando seu lixo. Esse trabalho de relançamento começou em dezembro de 2001.

Na fase anterior da implantação, eu participei em todas as fases, mas não atuei dentro dos grupos, eu participei fora, na coordenação da implantação da educação ambiental e da usina como um todo. Nós contratamos um grupo para fazer o trabalho de educação ambiental e eu observei todo o processo. E nesta observação, verificamos que o trabalho deveria envolver toda a comunidade.

Outra atividade, para a mobilização da comunidade, foi realizada no dia 13 de março de 2002, dia do relançamento da coleta seletiva. Essa atividade realizou-se em praça pública e constou de oficinas de compostagem, reciclagem de papel, oficina de brinquedos e cestaria. Observou-se que, neste dia, a maioria do público presente às oficinas foram estudantes das escolas da sede e dos distritos que transferiram suas atividades em sala de aula para a praça pública (Figura 19). Houve, também, apresentação de um musical sobre o tema lixo com chamada para que as pessoas aprendessem a cuidar bem de seus resíduos.

Segundo o professor que coordenou os trabalhos desenvolvidos pela escola no projeto de Educação Ambiental, as deficiências do projeto são devidas principalmente à falta de comunicação:

"Hoje eu sinto muita deficiência no projeto ainda. A gente vê que está faltando um pouco de cada um. Eu digo que não falta, apenas, a vontade da CAR, não falta vontade da Prefeitura, não falta vontade da gente, eu acho que está 
faltando mais integração por parte de todos. Eu acho que a gente pode melhorar isto, pode melhorar na questão de comunicação; como eu disse, o nosso grande aliado foi a rádio que tinha $\mathrm{cm}$ Mucugê e que foi fechada, uma rádio comunitária que não era legalizada e que acabou sendo fechada por denúncia. Faz uma falta muito grande, se tivesse a rádio, hoje, o nosso processo de coleta seletiva estaria muito melhor. Da mesma forma falta o carro de som sair mais vezes. Antigamente, ele saia toda semana, hoje, sai de mês em mês. O espaço de tempo está muito longo para se falar e quando sai, muitas vezes, não toca no assunto dessa questão do lixo especificamente. Então, acontece, a gente precisa estar escutando para se educar. As pessoas têm que estar ali todo o dia para não esquecer a sua função como cidadão $e$ nada melhor que os meios de comunicação para estar lembrando isto. Então, falta um pouquinho isto aí, pode ser corrigido, é coisa pequena que pode ser corrigida. Na escola, temos nossas deficiências, com essa correria do dia a dia a gente implantou novos projetos aqui na escola como a regularização do fluxo e a gente tem que estar dando as aulas. Nas aulas, todo dia tem que estar fazendo o relatório delas e muitas vezes, não se pode desviar a atenção para outro assunto. Aqui na escola, precisamos trabalhar mais isto no dia a dia da sala de aula, eles só trabalham quando eu reúno e converso: essa semana vai ser para isto, um sábado para aquele outro. Então, está precisando trabalhar mais o dia a dia e estar, diariamente, tocando nesse assunto de novo para despertar esta consciência". 
B

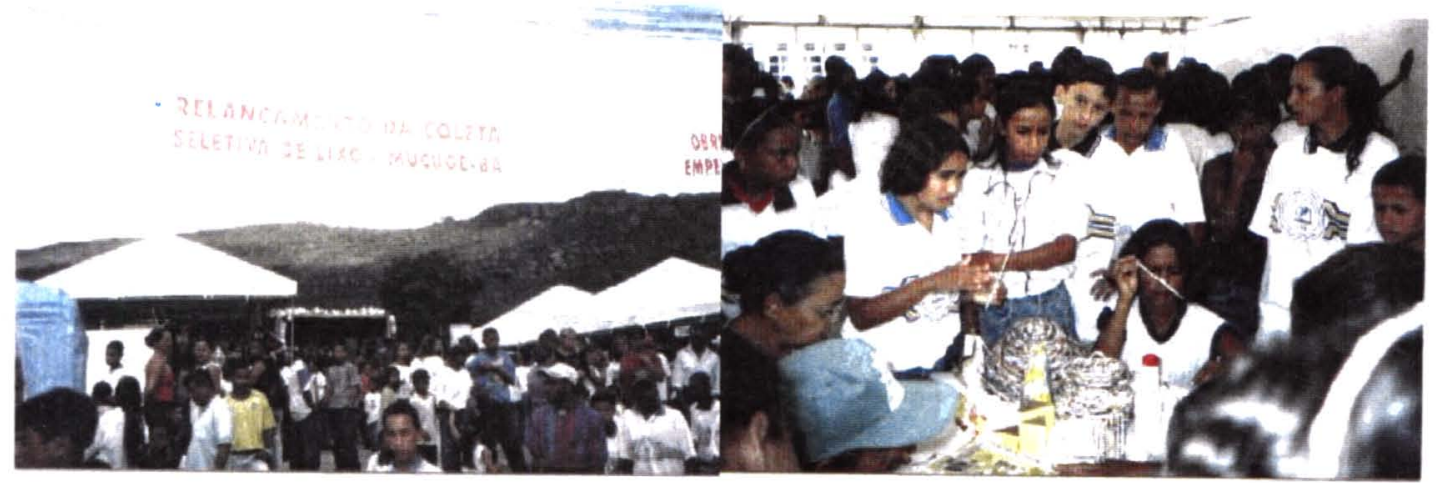

C

D
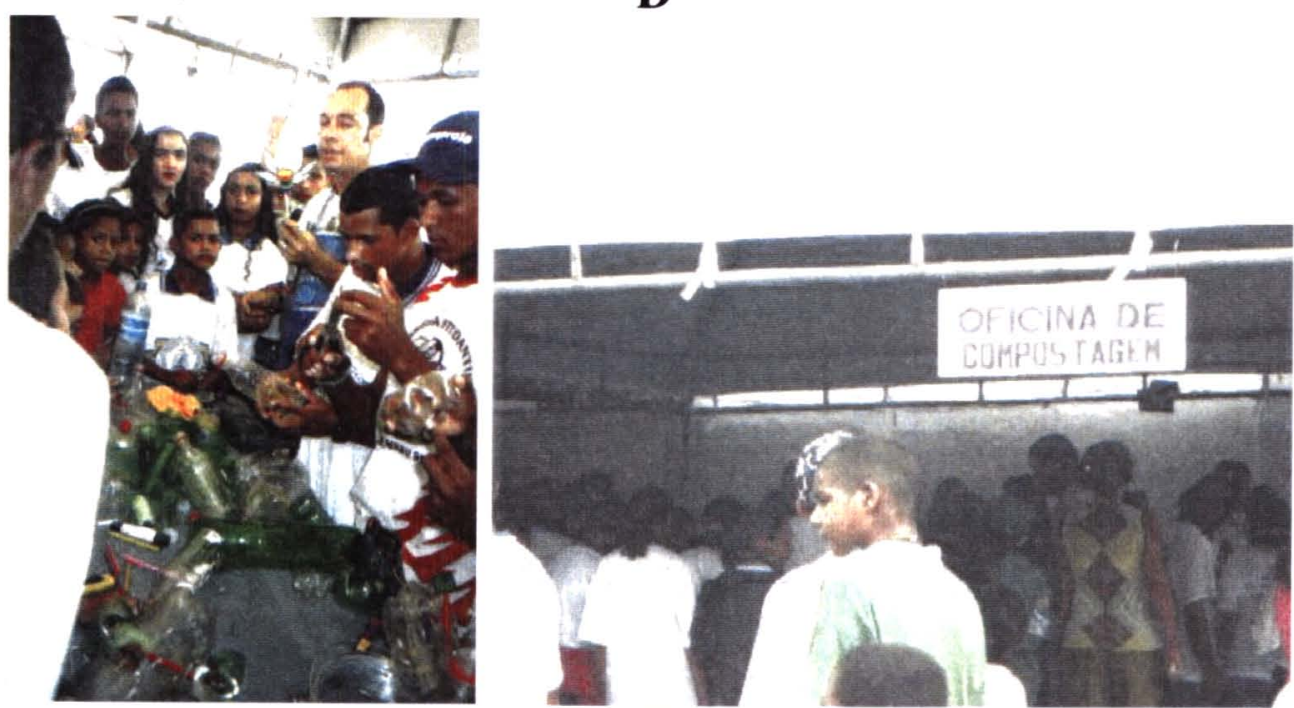

$\mathbf{E}$

$\mathbf{F}$
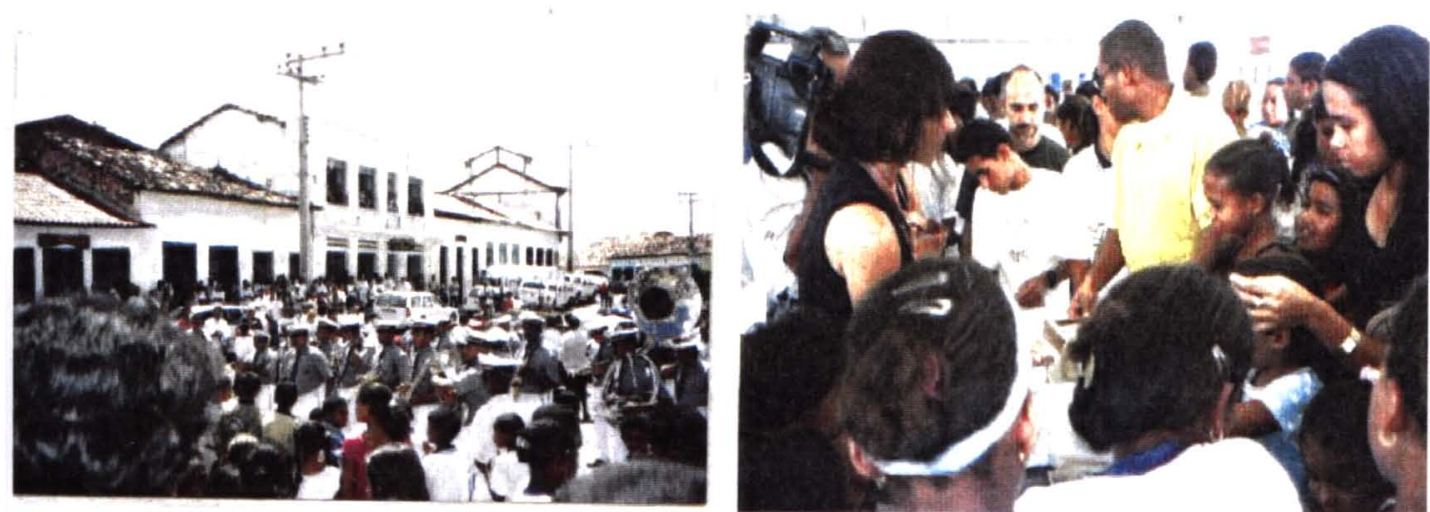

Figura 19 - Atividades realizadas em Mucugê para o relançamento da Usina Simplificada de Reciclagem e Compostagem. (A) Vista do local da realização das oficinas. (B) Oficina de cestaria. (C) Oficina de brinquedos de sucata. (D) Oficina de compostagem (E) Apresentação da banda de música local. (F) Oficina de papel. 


\subsubsection{O Discurso do sujeito coletivo}

A maioria dos sujeitos entrevistados nasceu no município de Mucugê. O sossego, a tranqüilidade e a paisagem são os motivos mais citados pelos entrevistados para estarem morando em Mucugê. Outros vieram para estudar e, também, devido à oportunidade de trabalho. A seguir, são apresentados os discursos dos sujeitos coletivos (DSC) referente a cada idéia central. No anexo 3 são relacionadas os grupos de expressões-chave referente a cada idéia central, expressa pelos diferentes sujeitos.

\subsubsection{O Discurso do sujeito sobre o projeto de Educação Ambiental desenvolvido aqui em Mucugê}

Sobre o projeto de Educação Ambiental desenvolvido em Mucugê obtiveramse dos discursos dos entrevistados, quatro idéias centrais. As expressões-chave referentes às atividades de sensibilização, presentes nos discursos, foram retiradas das entrevistas e colocadas agrupadas como uma idéia central para permitir uma maior visualização dessas atividades. São as seguintes as quatro idéias centrais obtidas:

a. Projeto relacionado à Usina de Reciclagem, acertos e desacertos (o início, a desativação e o retorno);

b. Atividades de sensibilização;

c. Projeto relacionado somente à usina que proporcionou melhoria da questão do lixo na cidade;

d. Projeto relacionado à usina e a outros projetos e necessidades;

e. Eu sei pouco sobre o projeto. 


\section{Idéia Central: Projeto relacionado à Usina de Reciclagem, acertos e desacertos}

\section{(o início, a desativação e o retorno).}

\section{DSC 1}

Este projeto começou em $98^{S 14}$ com o pessoal da CAR ${ }^{\text {S11,S14 }}$. O projeto foi desenvolvido para cuidar do ambiente da região por ser um local onde nós temos o Parque Nacional da Chapada Diamantina e hoje, tanto o governo do Estado como a prefeitura estão investindo no turismo ${ }^{514}$. Na gestão do outro prefeito foi que tivemos a oportunidade de ganhar essa usina de reciclagem ${ }^{54}$. Esse é um dos primeiros projetos da Bahia, este projeto de educação ambiental que é a usina de reciclagem ${ }^{S S, S 15}$ para recolher o lixo da cidade ${ }^{S 3}$. Para isto, houve um processo de conscientização ${ }^{S 1}$ para trabalhar principalmente com o lixo, como deveria ser usado o lixo orgânico para transformar em adubo para a própria cidade ${ }^{53, S 14}$. Daí, todo mundo selecionava seu lixo e deixava o saquinho na porta quando o carro passava $^{\text {SI }}$. Neste período, as coisas andaram muito $\mathrm{bem}^{S 1}$, o pessoal começou colaborando e acabou não colaborando mais. Pediam para separar o orgânico $e$ inorgânico e acabou misturando o lixo mesmo e o projeto parou ${ }^{\text {s11 }}$. Houve mudança de prefeito ${ }^{S 5}$, passou um tempo com negócio da política, a usina quebrou uma peça $^{S 15}$, a profissional responsável pela continuidade da usina foi dispensada ${ }^{S 1}$ e daí teve uma recaida ${ }^{S 5, S 11}$, começou todo o serviço caindo. O lixo, ninguém mais importava, ninguém exigia que o lixo fosse selecionado e foi bagunçando, caindo mesmo ${ }^{S I}$.

No segundo semestre de 2001, veio de novo toda a vontade e a preocupação de atuar de novo quando foi buscado, pela administração, contato de novo com Fátima, a engenheira responsável por este projeto ${ }^{S I}$ e daí, após este contato, começou a ter reuniões. Agora voltou a melhorar, o prefeito está empenhado, fazendo novas reuniões, o pessoal está selecionando o lixo direitinho, acho que está legal $^{55}$. O pessoal acha que o lixo deve ser jogado assim de qualquer jeito, mas não é assim, tem a reciclagem de lixo e tem dias alternados em que eles pegam o lixo. Todos os dias, pela manhã, eles pegam os detritos, restos de verduras e, uma vez na semana, eles pegam latas, garrafas, coisas que são recicláveis ${ }^{515}$. 


\section{Idéia Central: Atividades de sensibilização}

\section{DSC 2}

A Bahia é um Estado muito grande para Mucugê ser escolhida a cidade da reciclagem. Eu adorei ${ }^{s \sigma}$. Quando a usina inaugurou da primeira vez, há três anos atrás, a CAR pediu apoio do colégio e fomos aos pontos turísticos da cidade, ao redor da cidade recolhendo o lixo que tinha e fizemos um mutirão, teve festa ${ }^{\text {s3 }}$, teve gincana com o título de Reciclagem. Também, sem influência dos professores, os alunos tiveram que criar uma peça, eles só davam o tema e a duração da peça ${ }^{\text {s2 }}$. Teve ainda passeatas nas ruas ${ }^{56, S 7}$, organizamos e recolhemos todo o lixo que, depois de recolhido, foi levado para a praça. Daí surgiu a idéia da usina de reciclagem, para ajudar a população a separar o lixo e não ter muito lixo na rua ${ }^{S 2}$. Logo depois, o diretor do colégio pediu aos alunos da minha turma para sair de casa em casa distribuindo os folhetos e explicando ao pessoal como se fazia com o lixo dentro de casa para não prejudicar o pessoal que trabalhava na Usina ${ }^{\text {S2,S3,S6. }}$.

Teve um dia, que o colégio liberou para a gente fazer a limpeza dos rios, dividiu a sala em equipe, tendo uma professora responsável por uma turma e aí fazia limpeza e trazia e colocava na praça de eventos e a tarde foi pesar o lixo. Foi maravilhoso, pelo menos na beira do rio... porque o povo daqui não faz muita sujeira já pegou o hábito da limpeza ${ }^{56}$. Aqui a gente tem os professores que trabalham muito neste sentido, a gente já fez catação de lixo nos arredores uma, duas três vezes no dia Nacional de Meio Ambiente. Também há o interesse dos prefeitos neste sentido ${ }^{\text {S16. }}$.

Agora, o pessoal parou de separar, só que está voltando de novo e estão separando o lixo, colocando nos seus devidos lugares. O projeto parou porque não teve a influência da escola ${ }^{S 2}$.

Por isto, a técnica da CAR foi chamada e ela veio e procurou saber o que tinha dado errado, porque estava assim, o que levou a bagunçar tudo de novo. A comunidade tinha uma consciência boazinha e as coisas desandaram. Nas reuniões ia sendo colocado porque deu errado, o que está errado ali e o que a gente pode fazer para que melhore. Para a reunião, foram convocados os representantes da comunidade de vários setores, educação, saúde, meio ambiente, comércio, pessoal da justiça, todos os setores da sociedade estavam ali representados. Ali começou 
todo mundo se mobilizando e com vontade de contribuir para que a coisa voltasse a funcionar como era antes. Daí passou essa primeira reunião, a segunda, a terceira então, cada um que estava ali presente, começou a se comprometer a formar grupos, formar comissões ${ }^{S 1}$. Nós já tínhamos diagnosticado que o maior problema de selecionar o lixo em casa eram as empregadas domésticas ${ }^{S 1, S 5}$, visto que a mulher, dona da casa, está sempre fora trabalhando e quem mais lida dentro de casa e faz as tarefas domésticas é a empregada doméstica e ela não tem compromisso, ela quer se livrar de qualquer jeito e ensaca e põe o lixo de qualquer jeito lá na porta ${ }^{\text {st }}$. Para melhorar este problema, vamos realizar um seminário com as empregadas domésticas onde vamos ensinar tudo minuciosamente, muito simples, muito prático, do dia a dia sobre o que elas têm que fazer para selecionar o lixo em casa. Tentar sensibilizá-las que o pessoal que trabalha lá na usina são pessoas iguais a nós, que ficam recebendo esse lixo de qualquer jeito e se eles forem receber esse lixo melhor vai ser melhor para todo mundo, inclusive para a saúde deles e para o melhor aproveitamento do próprio lixo. Que tem lixo que vai muito sujo, como saco plástico melado e misturado com coisas sujas e daí não vai aproveitar nada ${ }^{S 1}$.

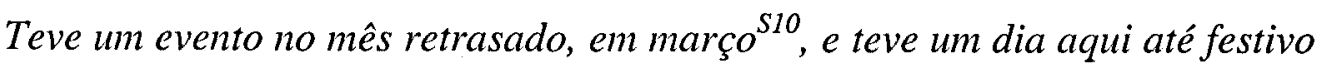
onde a CAR junto com Fátima e toda a administração da prefeitura fez um dia mostrando como é que o lixo pode ser reaproveitado ${ }^{S I}$. Neste dia, eles reimplantaram a usina de lixo, porque ficou um tempo parada. Teve o mutirão para todo mundo pegar o lixo e, depois disto, eles resolveram fazer um outro na reimplantação porque tinha parado tudo, ninguém estava separando, aquela coisa desorganizada. Então, eles reimplantaram, foi o maior evento, trouxe um monte de gente, inclusive eles ensinaram muitas pessoas a usar o lixo como trabalho educativo, fazer brinquedos, cartões, foi muito bom ${ }^{s 10}$. Várias vasilhas foram transformadas em brinquedo plástico, garrafa de guaraná, água mineral, tampinhas, várias coisas que a gente joga no lixo e pensa que não serve de nada foi transformado em brinquedos e também teve a reciclagem de papel. A população teve uma participação muito boa, o alunado todo esteve presente, o pessoal com a mão na massa mesmo aprendendo e fazendo. Também esteve presente uma banda de música. Depois, houve a exposição desses brinquedos todos, o papel depois de reciclado foi reaproveitado, então foi uma boa sensibilizada esta parte al ${ }^{S 1}$. 


\section{Idéia Central: Projeto relacionado à Usina que proporcionou melhoria da questão do lixo na cidade.}

\section{DSC 3}

Antigamente aqui era horrivel. Em todo o canto que você passava tinha lixo. Só depois de uns tempos para cá é que começou a se organizar. Antigamente, não tinha como transportar o lixo, o pessoal carregava o lixo numa carrocinha, uma carrocinha com um burrinho. Depois, arrumaram o carro e construíram a usina $^{59, S 17}$. Acho que melhorou muito, começou a reciclar. Eles começaram a tirar o lixo, no fundo do quintal ${ }^{59}$. No fundo da minha casa, era um lixão, aí, com este projeto, limparam a rua toda e, como tem a usina, tem a separação do lixo e a coleta do lixo todos os dias ${ }^{S 17}$,

Eu acho ótimo o projeto. As coisas correm bem, nunca faltou nada, educação. Sobre a coleta do lixo, é ótimo também. Aqui em casa, eles mandam separar eu estou fazendo; eles pediram para fazer a nossa parte que eles estão fazendo a deles ${ }^{S 8}$. Eu acho interessante porque vai para a usina, para fazer reciclagem ${ }^{S 8, S 16}$. Nossa cidade é uma das mais limpas da região e todo mundo está pronto para reclamar se alguma coisa não está direito. Estes dias, colocaram um balde para recolhimento de lixo e a gente reclamou para não deixar a vasilha parada naquele local, porque cada pessoa deve botar o lixo no horário correto para o carro pegar. O lixo é levado para uma usina, separado, as partes que podem ser recicladas são levadas para outra usina, não sei se é em Feira ou em Salvador, mas é aqui mesmo na Bahia. O lixo orgânico é transformado em adubo orgânico aqui na cidade mesmo, lá na parte da Fazenda Aracinópolis ${ }^{\text {s16. }}$.

Eu achei um trabalho muito bonito porque foi bem explicado com várias reuniões, horário de colocar o lixo, a separação do lixo, então foi uma coisa muito bem feita e está funcionando ${ }^{\text {S16. }}$. 


\section{Idéia Central: Projeto relacionado à usina e a outros projetos e necessidades}

\section{DSC 4}

$O$ projeto de Educação Ambiental foi iniciado na gestão do prefeito Fernando Medrado em que houve uma conscientização da população, principalmente dos alunos, por técnicos de Salvador e da Católica, que vieram aqui dar cursos, seminários para que houvesse essa conscientização e daí podermos trabalhar com os alunos para haver uma reprodução do que era, na verdade, o objetivo deste projeto. Foi iniciada na gestão de Fernando Medrado, praticamente, a conscientização. $\mathrm{Na}$ gestão do outro prefeito foi que tivemos a oportunidade de ganhar essa usina ${ }^{S 3,54}$ de reciclagem em que houve outro processo de conscientização trabalhando principalmente com o lixo, como deveria ser usado o lixo orgânico e o inorgânico. Daí, neste período, as coisas andaram muito bem, a cidade teve um crescimento muito rápido e hoje há a necessidade de uma reconscientização porque vieram muitas pessoas morar aqui que não estão inteiradas sobre este processo. Há necessidade de novos projetos para chamar a atenção da população para que se encaixem neste grupo que já está conscientizado ${ }^{S 4}$.

Além da Usina, tem o projeto Sempre Viva. Esse projeto é que gerencia o parque e eles plantam a Sempre Viva para ela não acabar ${ }^{53}$. Também se fala muito das queimadas; há cursos em Lençóis e em outros locais e o pessoal daqui vai sempre para saber como lidar com as queinadas que prejudicam muito. Temos também a questão da água que é essencial para a saúde e que necessita ser de qualidade, que nós não temos; temos água em quantidade mas não em qualidade. $O$ saneamento e a saúde estão ligados e nós não temos ainda a rede de esgoto, estamos procurando, mas como é um investimento caro até hoje não foi possível ter em Mucugê. A conscientização da preservação de toda esta natureza, de toda esta beleza, de todos estes mananciais que temos aí, devemos ter consciência disto $e$ fiscalizar também para que as pessoas que venham de fora não possam destruir ${ }^{\text {S4. }}$. 


\section{Idéia Central: Eu sei pouco sobre o projeto}

\section{DSC 5}

Eu sei muito pouco sobre o projeto ${ }^{S 13}$. Eu não participo de quase nada ${ }^{S 13}$, nem vou a reunião ${ }^{S 12, S 13}$ na cidade principalmente ambiental, devido ao tempo. Os horários das reuniões são sempre na parte da manhã e é um horário em que eu não posso frequentar ${ }^{\text {S12 }}$. Sei que eles gostam de conservar muito, mas não sei muita coisa não ${ }^{S 13}$. Então, eu faço do meu jeito, separo lixo de casa, lixo de cozinha, banheiro separado, plástico separado, vidro separado, cada um numa sacolinha separada. $\mathrm{Na}$ minha casa é assim ${ }^{S 12}$. 


\section{Análise da questão 1}

O projeto de Educação Ambiental, conforme os discursos obtidos, está relacionado à implantação da Usina de Reciclagem e Compostagem, para parte da comunidade, enquanto para outra, relaciona-se com outras questões ambientais como o Projeto Sempre Viva e com as queimadas que ocorrem eventualmente no local. $\mathrm{O}$ discurso referente ao pouco conhecimento sobre o projeto está ligado à coleta seletiva.

Para as pessoas que relacionam o projeto de Educação Ambiental com a implantação da Usina de Reciclagem, há uma percepção de que o processo funciona de forma adequada. Neste contexto, o projeto proporcionou a retirada do lixo dos quintais e ruas tornando a cidade mais limpa.

Para alguns moradores, ficou claro a descontinuidade do projeto, apontando os seguintes motivos: mudança do prefeito, questões políticas, dispensa do funcionário responsável pela Usina de Reciclagem e quebra de uma peça de reposição. Esse último motivo apresentado não procede uma vez que a Usina de Reciclagem é operada manualmente, tendo como único equipamento mecânico que poderia necessitar de peças de reposição uma prensa para a compactação mecânica do papel/papelão, plástico e latas.

Assim, percebe-se que não há uma clareza, na comunidade, quanto ao real motivo da interrupção da coleta seletiva na cidade. Da afirmação "ninguém exigia que o lixo fosse selecionado", pode-se inferir que a coleta seletiva não foi incorporada como uma nova atitude, mas, sim, como algo imposto por alguém e, no momento em que não há a cobrança, o lixo deixa de ser segregado na fonte geradora.

Quanto ao processo de sensibilização, realizado para levar a comunidade a participar da coleta seletiva, percebe-se que as atividades realizadas pela escola através de gincanas, mutirões de limpeza, visitas às residências, ficaram marcadas nos moradores. Segundo o professor que coordenou estas atividades, a escola, no interior consegue, por meio de atividades educacionais, abranger um grande número de pessoas da comunidade através dos alunos porque a maioria das famílias possui um de seus membros freqüentando a escola. Pelas características de Mucugê, cidade turística devido a suas belezas naturais, a escola criou as disciplinas Turismo e 
Jornalismo, além daquelas do núcleo comum. Essas disciplinas têm como objetivo envolver o aluno em atividades de interesse local:

“Além de fazer gincanas, conseguimos fazer outros mutirões, conseguimos realizar campanhas diversas nos lares das pessoas, levando-lhes panfletos explicativos. Cada equipe de sala de aula ficou responsável por conversar com as donas de casa de uma rua para ensinar a separar o lixo; isto foi na primeira fase do projeto, onde aprenderam a coletar o lixo de maneira correta. E aí nós conseguimos, nós tínhamos uma rádio local que deu muito apoio, a rádio do Projeto Sempre Viva, que, infelizmente, foi fechada. A escola montou um programa nessa rádio, um rádio jornal informativo, que ia ao ar três vezes por semana com os próprios alunos sendo as cabeças e um ou dois professores ajudando na organização. Sempre um recadinho na hora da notícia, aquele recadinho não deixava de ter um incentivo para os moradores não esquecerem a coleta. Nós tínhamos um horário bom que era durante o meio dia".

$\mathrm{Na}$ parte das disciplinas diversificadas, nós colocamos duas no currículo, também voltadas para isto: turismo e jornalismo escolar, em virtude desse rádio jornal que a gente abriu. A matéria Turismo iria abranger, não apenas esta questão do lixo, mas a questão ambiental como um todo, como receber o turista e tudo. Essas matérias estão no nosso currículo até hoje e nós continuamos a trabalhar isso no ensino fundamental. Também no ensino médio, nós temos, no primeiro ano, a disciplina Turismo que surgiu em função disto. Porque antes, a gente não tinha atentado ainda para essa questão e, em virtude desse projeto, desse programa todo, a gente sabe que todas as disciplinas trabalham a questão ambiental. Isso ai é multidisciplinar, mas sei que a gente tem que ter uma atenção mais especial, então o foco mais especial é dado exatamente nessas disciplinas que a gente criou”. (Professor coordenador das atividades educacionais realizadas pela escola).

Sobre o projeto de Educação Ambiental realizado para o relançamento da Usina Simplificada de Reciclagem e Compostagem, há pouca referência sobre a idéia de formação de grupos para a criação da rede local de mobilização. A atividade de sensibilização que emerge dos discursos são as oficinas de reaproveitamento de lixo realizadas em praça pública no dia do relançamento da usina. 
Apenas foi lembrada a formação do grupo das empregadas domésticas, por serem elas as que manuseiam, dentro das residências, os resíduos gerados diariamente. Esse grupo ainda não tinha passado pelo processo de capacitação previsto no projeto.

\subsubsection{O Discurso do Sujeito Coletivo sobre as mudanças ocorridas em Mucugê em função do projeto.}

Das respostas obtidas à questão sobre as possíveis mudanças ocorridas na cidade em função do projeto obteve-se três idéias centrais:
a. Mudou a consciência das pessoas;
b. Mudou a cidade;
c. Não mudou muito.

\section{Idéia Central: Mudou a consciência das pessoas}

\section{DSC 1}

Mudou, na limpeza geral da cidade. As pessoas se conscientizaram, nem todos, mas boa parte das pessoas, a maioria delas tem consciência e estão começando a separação do lixo e ajudando no projeto $^{S 1, S 3, S 4, S 10,517}$, porque, além de ajudar a comunidade, o projeto ia trazer grande benefício, porque ia gastar bem menos, porque iam pagar menos pessoas para separar o lixos1. Antes era ruim, agora está melhor. Antes, não pedia para separar, ninguém separava, misturava tudo, depois que surgiu isto aí, achei muito bom ${ }^{S 7}$, pois o pessoal tem mais conhecimento sobre o lixo, sobre o meio ambiente e onde deve ser colocado o lixo ${ }^{510}$. Só que à proporção em que mais pessoas vieram morar em Mucugê, ele não foi divulgado para chegar a estas pessoas, então nós moradores mais antigos já estamos conscientes do nosso papel mas essas outras pessoas que estão chegando não estão. Então além de fiscalizar, nós temos a obrigação de conscientizar ${ }^{\text {S3 }}$. 


\section{Idéia Central: Mudou a cidade}

\section{DSC 2}

Eu acho que sim porque em 1995 a cidade não tinha nem coleta de lixo ${ }^{S 14}$, o lixo era espalhado, jogavam o lixo em qualquer lugar e também as pessoas jogavam o lixo nos fundo das casas ${ }^{S 4, S 16}$. O lixo era jogado perto desse morro alto, logo depois do cemitério, mas era fedido, era ruim de passar ${ }^{\text {S16 }}$ e aí se começou a fazer a coleta de lixo com uma carrocinha puxada por uma mula, depois entrou uma Toyota. Até então os becós da nossa cidade, aquelas transversais eram todas tomadas pelo lixo, a cidade tinha muito rato, muito inseto, a gente vivia constantemente colocando remédio no quintal para matar os bichos ${ }^{514}$ e agora o lixo tem um local para ser

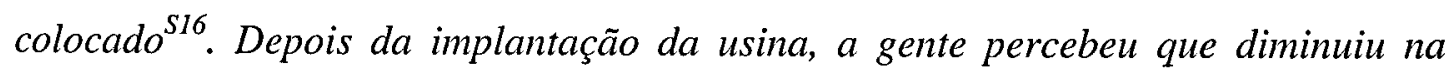
quantidade de inseto na cidade, os ratos não se proliferam mais. Então, eu acho que a usina mudou a vida da população para melhor, porque hoje a população vive num

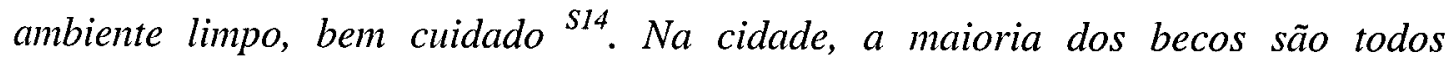
limpinhos, capinadinhos pode ser de chão batido, que é tudo limpo, as ruas são muito bem varridas ${ }^{514}$.

Então a cidade mudou, ainda não tanto, resultados concretos ainda não se está tendo, mas pelo processo que está vindo aí vai ter um bom resultado. Primeiro um resultado ambiental, porque já que parou de jogar lixo no lixão, este lixo está tendo outro destino $^{\text {s13 }}$. O lixo hospitalar mesmo está tendo um aterrozinho sanitário e esse lixo todo está sendo direcionado para este aterro sanitário, e claro que os benefícios são muito grandes. Também tem o benefício comercial de rentabilidade ${ }^{S 13}$ e uma cidade turística não deve ficar suja. Hoje em dia a cidade é limpa, tudo é reaproveitado ${ }^{56}$. Em relação a limpeza ${ }^{S 5, S 6, S 11}$, hoje em dia você anda nas ruas e não vê aquela quantidade de lixo que incomodava. Até quando chovia o cheiro era insuportável $^{S 8}$, ficou limpa, e a própria conscientização do povo ${ }^{S 4, S 9}$. O pessoal ficou bem educado com este negócio de lixo e você pode reparar, a cidade não tem papel, não tem copo, não tem lata jogada. O pessoal é super educado, todo mundo joga no lixo certinho, a cidade é muito limpa ${ }^{S 9}$, então quem entrar aqui vai sempre notar que é uma cidade educada com relação ao lixo ${ }^{S 9}$. Antigamente, não era tão sujo ${ }^{S 9, S 11}$, mas o pessoal não tinha educação porque sempre teve quem varresse a rua, nunca 
deixaram a rua suja, mas se encontrava papel de bala, o jardim estava sempre com papel e hoje, você não vê isto pois está tudo muito limpinho e quem vem aqui diz: oh! vocês têm uma cidade muito bem educada em relação ao lixo porque todo o mundo joga no lugar certo e antes não era assim ${ }^{59}$. Se uma pessoa joga uma lata de refrigerante na rua, eu vou lá e pego, eu fico até com vergonha, mas eu faço isto: eu vou lá e pego e jogo no lixo ${ }^{s 5}$.

\section{Idéia Central: Não mudou muito}

\section{$\operatorname{DSC} 3$}

Conscientizou um pouco a população, mas estou achando que agora está um pouco esquecido este negócio da coleta, porque têm famílias que não sabem quais os horários em que vai passar para coletar o lixo reciclável, o horário para pegar o lixo não reciclável. Mudou um pouco, aí esqueceu. Na época, em que tinha a rádio que divulgava, o pessoal colocava o lixo separadinho, agora não, nem todas as casas separam o lixo, está um pouco esquecido. Não mudou muito não $o^{52}$, está parado, antes era bem mais desenvolvido ${ }^{\text {S12 }}$.

\section{Análise da questão 2}

Os discursos das pessoas que percebem mudanças na cidade de Mucugê com a implantação do projeto, relacionam essas mudanças, principalmente, com a limpeza da cidade, e conseqüentemente, com a diminuição de insetos que proliferam no lixo. Também o projeto trouxe conhecimento em relação ao lixo e a sua separação, e uma melhoria ambiental, uma vez que, a partir da implantação da Usina Simplificada de Reciclagem e Compostagem, o lixo deixou de ser jogado em lixões e nas ruas, e passou a ter um destino adequado.

Há também percepção de que em Mucugê, por ser uma cidade turística, o manuseio correto do lixo traz ganhos econômicos, porque uma cidade limpa atrai turistas. Também há um ganho econômico no momento em que as pessoas separam seu lixo e, com isso, há uma menor necessidade de mão de obra na usina. 
Nota-se uma preocupação com a divulgação do projeto aos novos moradores da cidade para que eles tenham conhecimento da forma de gerenciamento do lixo, incentivando seu engajamento no processo. Também se percebe que, para algumas pessoas, o projeto não está tão bem quanto no seu início, devido à falta de divulgação dos horários de coleta e pela menor participação dos moradores na segregação do lixo na fonte geradora. 


\subsubsection{O Discurso do Sujeito Coletivo mudança pessoal em função do projeto.}

Dos discursos do sujeito coletivo, resultantes das respostas às entrevistas sobre a questão relacionada à mudança pessoal em função do projeto de Educação Ambiental realizado em Mucugê, emergiram quatro idéias centrais:
a. Mudou na separação do lixo;
b. Mudou porque eu vivo disto;
c. Não mudou;
d. Já era educado sobre isto.

\section{Idéia central: Mudou na separação do lixo.}

\section{DSC 1}

Mudou $^{52,56,58,59,511,515,516,517}$ sim. Mudou e eu acho muito bom, porque viver numa cidade igual à que a gente vivia, eu acho que nenhum ser humano gostaria de viver $^{S 8}$. A diferença de jogar um lixo em qualquer lugar e jogar no lugar certo $e$ saber como ele vai ser deteriorado, muda porque, se você jogar este lixo em qualquer lugar, além do mau cheiro, ia sujar o local, nâo ia dar certo. A pessoa ia passar e ver aquele monte de lixo como tem em algumas cidades em que se joga no lixão, no buraco e queimam tudo, mas, mesmo queimando, fica porque os animais carregam para outro lugar ${ }^{59}$. Antes, eu jogava o lixo fora, no meio da rua, o pessoal pegava e jogava no lixãos ${ }^{S 6}$, não tinha usina, jogavam no lixão, queimavam e estava prejudicando o meio ambiente ${ }^{S 6}$, eu não sabia de nada. Depois que veio este projeto e o pessoal começou a ensinar na escola, daí eu fui botar na minha cabeça que estava prejudicando o meio ambiente ${ }^{S, S \sigma}$. Provocou bastante mudança no geral porque, na verdade, a gente tinha a teoria mas não fazia a prática, sabia o que era certo, mas não fazia e, a partir dessa participação, desse projeto, desses cursos, desses seminários, nós começamos a por em prática que é o importante, porque saber, todo mundo sabe, mas fazer é que é o importante ${ }^{S 3}$. A gente aprendeu muita coisa com este projeto, a separação do lixo: às vezes, eu ficava na dúvida do que era orgânico e o que era inorgânico, coleta de lixo, separação do lixo, como era feita, como eles faziam lá na usina, que o lixo orgânico eles utilizavam para fazer adubo. 
Isso é muito bom e o pessoal de casa fica sabendo disto e não vai jogar os restos de comida e de verduras que servem como adubo também, então é muito bom ${ }^{517}$.

A gente não mistura mais o lixo porque aqui em casa a gente fiscaliza ${ }^{S 16}$. Em casa eu acabo separando o lixo ${ }^{S 2, S 10}$, a gente vê onde está colocando a garrafa, onde está colocando o lixo orgânico ${ }^{S 16}$, resto de comida ${ }^{S 10}$, onde está colocando o papel higiênico porque a gente separa e hoje a gente usa isto para educar os menores. Se for uma garrafa, um copo que partiu, também sabe onde colocar, então ajudou também em casa a manter o asseio e o cuidado, achei muito bom ${ }^{\text {SI6 }}$. Se hoje quebra uma lâmpada em casa ou um copo, eu enrolo num jornal coloco num saco e daí jogo no lixo, porque quando chegar lá, eles vão pegar, eles podem cortar a mão como aconteceu muitos vezes aqui. A partir do momento em que começou a reciclagem, eu já faço isto direto, os meninos que trabalham no lixo dizem que é um dos lixos melhores de Mucugê $\hat{e}^{S 5}$.

Também, quando eu estou em qualquer lugar e descasco uma bala e se não vejo onde jogar, automaticamente guardo na bolsa ou no bolso. Quando vou para a minha cidade natal, lá não tem esse processo e quando estou fazendo alguma coisa lá eu separo as coisas na cozinha. e fico com aquele desejo de que, em todo lugar, esteja acontecendo isto. A gente vê que muitas doenças surgem do lixo, do acúmulo de lixo, muitos insetos, microorganismos proliferam a partir dali ${ }^{S 13}$, principalmente porque aqui chove muito e isso tudo vai acabar dentro da água e vai contaminar as pessoas $^{\text {s11. }}$.

Então, esse projeto vem em benefício da natureza e nós somos um dos poucos privilegiados com a natureza que temos, ar puro, rios para tomar banho, apesar do Rio Mugugê, infelizmente, está proibido para o banho ${ }^{S 15}$.

\section{Idéia central: Mudou porque eu vivo disto}

\section{DSC 2}

Para mim, foi bom porque participo diretamente do projeto. Eu começo na coleta, depois venho para a separação, pesagem, prensagem, venda de material, recepção de visitante. Então, para mim, melhorou porque hoje eu tenho um trabalho 
seguro, desde que feito direitinho, participo de tudo isso aí e tenho um padrão de vida muito bom também ${ }^{\text {SI4 }}$.

\section{Idéia Central: Não Mudou}

\section{DSC 3}

Também não mudou ${ }^{S 12}$, acho que não ${ }^{S 1}$.

\section{Idéia Central: Já era educado sobre isto}

\section{DSC 4}

Com esta questão de ser guia, eu sempre defendi o meio ambiente, fui um pouco educado em relação a isto, houve alguns cursos com os guias ${ }^{\text {s4 }}$.

\section{Análise da questão 3}

As mudanças pessoais descritas nos discursos são fortemente relacionadas ao conhecimento sobre a problemática do lixo a partir da sua geração. Dentre os problemas apontados destacam-se:

- O lixo prejudica o meio ambiente.

- O lixo com características cortantes (vidros quebrados) pode causar danos à saúde do pessoal da coleta e da usina.

- Doenças relacionadas ao acúmulo de lixo através de vetores e microorganismos que se proliferam a partir do lixo.

- Contaminação do Rio Mucugê, cuja qualidade das águas está imprópria para o banho.

O projeto trouxe conhecimento sobre os tipos de lixo gerado, sobre a possibilidade de seu reaproveitamento e sobre o processo de compostagem. A implantação do projeto permitiu que os conhecimentos teóricos fossem praticados, inclusive, percebe-se, no discurso, um desconforto pessoal quando do manuseio do lixo em outras localidades que não possuem a segregação na fonte para a coleta seletiva. Percebe-se, também, a mudança de hábitos no sentido de não se jogar lixo na rua. 
Interessante a colocação de um morador, ao dizer, "o pessoal da usina diz que o meu lixo é um dos melhores de Mucugê" no sentido de que a segregação é bem feita, inclusive, apresentando as embalagens limpas e lavadas. Como a cidade é pequena, há possibilidade de identificar o lixo por casa e, neste contexto, pode haver uma intervenção direta em locais onde a segregação não está sendo realizada de modo satisfatório.

Percebe-se que há um sentimento de valorização da natureza local, pelo ar puro, rios para banhar-se e pela beleza natural comum em muitos municípios da Chapada Diamantina. Esse fato incentiva a parte subjetiva de muitos moradores com um sentimento de orgulho de pertencer àquele local.

Não houve argumentação por parte das pessoas que afirmaram que o projeto não trouxe mudança pessoal.

\subsubsection{O Discurso do Sujeito Coletivo sobre a participação da comunidade no projeto}

As representações da comunidade sobre a participação no projeto foram agrupadas em quatro idéias centrais:

a. Não participo do projeto, só em casa, como cidadão fazendo a minha parte;

b. Participo na separação do lixo da minha casa e/ou da empresa;

c. Participo de várias formas;

d. Participo através do nosso trabalho. 
Idéia Central: Não participo do projeto, só como cidadã fazendo a minha parte

\section{DSC 1}

Eu não tenho participação ${ }^{S 4, S 7, S 12, S 16}$ nenhuma. Para mim é normal ${ }^{S 5}$. Eu fui lá na reciclagem e vi o trabalho deles na usina: eles põem a mão naquele lixo podre, cheio de bicho. Então eu faço a minha parte em casa, separo sempre o lixo ${ }^{54, S 12}$ como eles sempre avisaram para separar. Em casa, a gente separa o papel coloca em uma sacola, verdura a gente coloca em outra, tudo separado em sacola ${ }^{55,58}$. $O$ papel higiênico eu separo, as latas, restos de alimentos, cascas de verduras e tudo eu sempre procuro fazer a minha parte $e^{S 5, S 12}$. Eu já lavava o meu lixo, uma lata de manteiga eu jogo água fervendo, vou lavo, nunca jogo sujo eu sempre faço isto ${ }^{5 S}$. Não deixo as crianças jogarem o lixo na rua ${ }^{S 12}$, eu fiscalizo de modo geral os visitantes. Se o povo daqui joga lixo no chão, a gente vai lá e pega ${ }^{54}$. Faço porque é bom para a comunidade, só que muitos não fazem isto. Desde que começou a reciclagem, eu faço e continuo fazendo e se isto acabar eu vou continuar fazendo porque para mim não pesa, não dá trabalho de separar o lixo da gente todos os dias em sacolinhas.

Se eu vejo uma coisa na rua fora eu chamo o fiscal e falo com ele, sempre estou atenta a isto. Às vezes, o córrego ali está obstruindo, porque passa um córrego ali, é um esgoto a céu aberto, então qualquer problema, eu vou lá e falo com ele que está entupindo, é só dando um jeito, eu sempre falo. Tem este problema de colocar o lixo fora de hora, eu falo com o próprio morador, falo com o fiscal e ele vem vai direto na casa e chama atenção. Então eu participo assim, não faço parte do grupo e da associação mas eu faço a minha parte ${ }^{\text {Sl6 }}$.

\section{Idéia Central: Participo na separação do lixo da minha casa e/ou da empresa}

\section{DSC 2}

Participo assim através da separação do lixo, a participação é só em casa

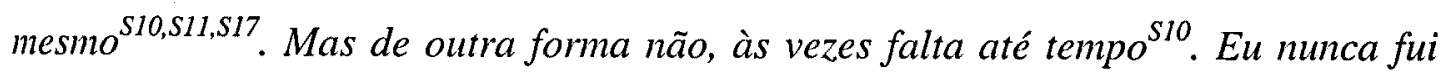
em reunião, estava ocupada, foi anunciado no carro de som mas eu nunca fui ${ }^{\text {sll }}$. Aqui na loja, como o lixo é inorgânico a gente separa tudo, as vezes tem uma coisa 
orgânica como casca de fruta essas coisa então eu ponho dentro de uma sacola e não ponho no lixo aqui da loja, que é inorgânico, levo os dois separados ${ }^{\text {SI7 }}$.

Aqui na pousada, as cascas de verduras tem um rapaz que joga para os porcos. A parte que a gente mais separa é lata, restos de plásticos, papel, caixas, temos as vasilhas e tudo está separadinho. Agora o projeto ficou meio bagunçado,eu não sei se a usina está reativada, o pessoal de casa não estão conscientizado, porque antes tinha rádio e tinha avisos tudo certinho e todos tinham que separar o lixo, contudo eu acredito que hoje não estão separando como antes. Mas este trabalho que eles fizeram no mês de março foi para reiniciar e botar tudo para funcionar novamente ${ }^{s 9}$.

Eu participei desse evento de relançamento, deste último que teve aqui na praça. Eu não sabia uma parte do que eles falaram que tinha que lavar as vasilhas de catchup e refrigerante. Então, se não tivesse tido esse evento eu não poderia saber. Teve também aquelas garrafas de refrigerante de 2 litros que você pode fazer tanta coisa com ela, o papel então, se não tivesse tido, eu vejo muitos alunos no colégio que fazem umas cestinhas de revistas e jornais. Então, hoje, eu vejo que muitas crianças fazem aquela cestinha porque aprenderam naquele tempo, nesse evento que teve. Então, educando as pessoas e mostrando que, além de jogar fora, ele pode servir como um brinquedo, um porta jóia, um cartão, a pessoa vai vendo reciclar, aprende e não vai mais jogar no lixo. Só esse evento não serve, porque eu acredito que deve ter mais, pois eu vejo que muitas pessoas vão lá e aprendem, mas tem muitas pessoas que não se interessam de ir ou, talvez, não pode sair na hora para ir. Então, devia ter outra coisa, um aviso, não sei como deveria ser trabalhado isso, além de eventos, deveria ter algo mais para incentivar isso e não esquecer nunca de separar, não esquecer nunca dessa regra, deve incluir isto na vida ${ }^{s 9}$.

\section{Idéia Central: Participo de várias formas}

\section{DSC 3}

Participo como cidadão ajudando a alertar o pessoal que não entende do projeto $^{S 6}$. Eu participei explicando para as pessoas ${ }^{s 1}$, participei do mutirão $e$ participo dentro de casa separando o lixo ${ }^{51, S 2}$. Eu ajudei a distribuir os folhetinhos $e$ 
também participei do concurso de melhor frase melhor cartaz e fiquei em terceiro ligar, a frase era "A ferramenta adequada para acabar com o lixo somos nós mesmos".

Eu participo desde que surgiu esta vontade de se engajar mais diretamente. Antes eu já participava como dona de casa, como mulher, como cidadã e hoje eu participo como profissional ${ }^{\$ 13 . S 15}$ mesmo, como colaboradora mais direta $e$ desejando que este projeto venha dar certo ${ }^{\text {S13 }}$. Além de participar como profissional, aqui em casa eu separo, garrafas, potinho de manteiga, eu geralmente os reutilizo, eu lavo também e jogo sempre limpinho, garrafa de leite de coco eu lavo, massa de tomate em lata eu lavo, cascas de alimento eu jogo no quintal para adubar porque o solo é arenoso ${ }^{515}$. A gente tem que ter nossa parcela de contribuição para o que a gente quer que dê certo, a gente tem que contribuir, não pode ficar sentada esperando ${ }^{\text {S13 }}$.

Participo diretamente. Eu fui treinado pelo pessoal da CAR, por Fátima Gutierres, por Millena que é da Faculdade de Feira de Santana, que foi a primeira bióloga que esteve aqui e nos ensinou o processo de compostagem. Eu participo diretamente, fui treinado para poder ajudar o pessoal, primeiro para fazer a coleta, depois fazer a seleção do material e tenho orgulho disto de participar porque é um projeto piloto e hoje, pelo que nós sabemos, vai ser copiado para mais 10 municípios do Estado da Bahia, porque este aqui deu certo, apesar de ter algumas deficiências, ele deu certo ${ }^{\text {S14 }}$.

\section{Idéia Central:Participo através do meu trabalho}

\section{DSC 4}

Através da aula, eu procuro sempre que posso, se estou trabalhando com um texto, abrange esse assunto, já que sou professora de língua portuguesa. Procuro mostrar aos alunos e direcionar para que eles se conscientizem disto. Diretamente no projeto eu não trabalho, até porque não tenho tempo ${ }^{S 3}$. No nosso trabalho a gente orienta as donas de casa sobre o lixo como separar, que não deve colocar comida junto com lata, vidro depois de ser usado lavar e deixar escorrer a água para não dá mosca. Fizemos um trabalho de conscientização das famílias sobre a dengue, passamos de casa em casa, olhamos os quintais, plantas. A gente está assim sempre 
batendo na mesma tecla, as pessoas não aprendem de um dia para o outro tem que estar renovando, buscando, falando, mas, graças a Deu,s em Mucugê está bom ${ }^{S I S}$.

\section{Análise da questão 4}

Como observado no campus da UEFS, a separação do lixo na fonte é, para alguns, uma forma de participação no projeto, enquanto, para outros, é uma atitude normal de fazer a sua parte. Esses últimos consideram que separar o lixo não dá trabalho, dando a entender que a participação no projeto vai mais além, como fazer parte do grupo ou da associação.

Parte da comunidade relata que participa de várias formas, como em atividades de sensibilização, divulgação e orientação sobre o projeto, além de separar o lixo em sua casa. Essas pessoas demonstram orgulho de participar do projeto e pensam, positivamente, no êxito do mesmo.

Parte dos sujeitos entrevistados afirma que participa do projeto em função de seu trabalho. A professora, por meio de sua disciplina, direciona o conteúdo de suas aulas para as questões ambientais, enquanto que o pessoal ligado à saúde orienta a comunidade sobre como proceder quanto a separação do lixo e na prevenção de doenças a ele relacionadas.

\subsubsection{O Discurso do Sujeito Coletivo sobre a avaliação do projeto.}

Quanto a melhorias no projeto, os entrevistados se posicionaram dentro de quatro três centrais. Houve um grupo de pessoas que consideram que o projeto está bem e que não precisa de melhorias. As quatro idéias centrais obtidas:
a. Não precisa de melhorias;
b. Melhorar a divulgação/conscientização e mobilização;
c. O projeto deveria tratar de emprego;
d. Aumentar os vasilhames nas ruas e melhorar a parte operacional da usina. 


\section{Idéia central:Não precisa de melhorias}

\section{DSC 1}

Por enquanto está bom, agora se eles pudessem melhorar, por exemplo, chegar em outros municípios e passar isto para frente seria muito bom, não só para a gente como para a natureza também, porque tem muitas coisas agressivas para a natureza como o vidro, o plástico que a terra não decompõe $e^{S 17}$. Eu acho que se continuar igual estão fazendo, eu não tenho o que dizer, nãoss. Agora, para Mucugê ficar bom mesmo é começar por saneamento básico: esgoto e tratamento de água. Sem saneamento básico, fica impossível. Que não adianta, limpar a casa e jogar o lixo na porta. Não adianta, você entra na casa é uma maravilha, limpinha mas joga o lixo na porta. Para Mucugê ficar bom mesmo é começar por saneamento básico, esgoto e tratamento de água ${ }^{515}$.

\section{Idéia Central: Divulgação/conscientização e mobilização}

\section{DSC 2}

Eu acho que para melhorar só precisa mesmo da colaboração total da população, fazendo a seleção prévia em suas casas. O esquema que foi feito pela CAR é um esquema certo, um esquema lógico da coisa funcionar. Se não funciona melhor, é por falta de colaboração de alguns ${ }^{S 14}$. Assim, o projeto tem necessidade de modificar algumas coisas: conscientização total das pessoas ${ }^{53}$, deveria divulgar mais o projeto ${ }^{S 2, S 10}$ em ruas, residencias e nessa parte comercial ${ }^{S 10}$, porque às vezes a gente até esquece que tem a usina de reciclagem na cidade ${ }^{S 2}$. Está faltando organização, planejamento mais adequado ${ }^{S 2}$.

A divulgação poderia ser através de programas, de peças de teatro em praça pública, que é uma coisa a que todo mundo tem acesso, criar ações de jingles para colocar no carro de som para que a cidade toda fique ouvindo e aí, vai dando o estalo do que dever ser feito. Ter mais propaganda, cartazes, colocasse mais pessoas para orientar o pessoal na rua ${ }^{S 3, S 6}$ estas coisas, para que esteja sempre presente no cotidiano das pessoas e não pensem que o projeto acabou ${ }^{S 3}$. Então, deveria fazer mais campanhas ${ }^{56}$, tivesse uma reunião para explicar as pessoas como deveria ser, pois muita gente não sabe ${ }^{\text {shl }}$, pelo jeito ninguém está entendendo sobre o projeto ${ }^{\text {s6 }}$. 
Para mobilizar a população, é a pesquisa de corpo a corpo, usando os alunos da escola. Este trabalho tem que começar dentro da escola, conscientizando as crianças a fazer este processo dentro da escola. Daí, cle leva para casa dele e vai cobrar do pai, da mãe, da empregada, eu acho que aí dá certo ${ }^{\text {S14. }}$.

Também, deveria haver mais reuniões com as donas de casa, mais participação delas, daí melhorava mais ${ }^{55}$. E até para o próprio turista, porque tem muito turista educado mas, também, tem muito turista mal educado. Eu moro ali na praça e vejo direto. Eles chegam, bebem refrigerante. jogam a lata na rua, bebem IIm iogurte e jogam na rua, comem biscoito e jogam o papel na rua. Então, para eles também, se tiver uma coisa mais estampada, mais vista até repreende, eu acho que deveria ser feito isto. Porque aqui vem muito turista conscientizado, porque quando está dentro do projeto Sempre Viva, ele já entra receoso, mas ele esquece e quando chega na rua faz. Chega ali adiante não está a fiscalização e faz. Se tivesse em todos os locais estampado para ele ver, despertaria mais e se policiava mais ${ }^{S 3}$.

O projeto deveria também mostrar a reciclagem, a gente não vê o reciclado, eles reclamam, mas a reciclagem a gente não vê quase nada do que fizeram, do que estão reciclando. Eu acho que deveria ter mais atividade até para vender, ter oficinas de arte, de reciclagem e aqui não tem ${ }^{\text {SI2 }}$. Inclusive, poderia ter um trabalho, tipo incentivar o pessoal de alguma forma, com prêmio, alguma coisa assim, porque o pessoal está muito desanimado. Talvez, incentivando, dando uma gratificação, qualquer coisa que incentivasse tipo: ele recebeu um prêmio eu também vou lutar, vou fazer a mesma coisa para receber, vou separar o meu lixo, acho que precisa de um incentivo porque o pessoal está meio desanimado com essa separação do lixo. Também acho bom a pessoa estar sempre em casa avisando. Se o rapaz do lixo está sabendo qual o lixo que não está vindo separado, então ele podia passar isto para o gerente da usina e ele ter uma conversa com essa pessoa de uma forma educativa para ele separar esse lixo. Se o pessoal está ficando fraco, tem que vir alguém para reforçá-los ${ }^{\text {s9 }}$ 


\section{Idéia Central: O projeto deveria tratar de emprego}

\section{DSC 3}

$\mathrm{Na}$ cidade tem muito pouco trabalho, tem muita gente que precisa de emprego e não tem. O projeto deveria tratar desse assunto ${ }^{57}$.

\section{Idéia Central: Aumentar os vasilhames nas ruas e melhorar a parte operacional da Usina}

\section{DSC 4}

Eu acho que deveria ter mais vasilha para o lixo na rua porque tem pouco aqui, na cidade, na minha opinião deveria ter bem mais. Só colocam aquela vasilhas grandes na rua quando vai ter festa ou exposição, depois disto, tiram e não colocam mais $^{S I}$. Também na questão de comportar o lixo da cidade. O número de habitantes cresceu muito, é um absurdo o que vai de lixo por dia para a usina, é mais de 2 a 3 toneladas e não foi projetada para isto. Tem uma parte que eles não separam por não ser papel, orgânico, vidro, lata de óleo, que é o papel higiênico e o jornal velho que estão jogando aí e está ficando feio. O que poderia melhorar era a estrutura, o depósito de lixo, não sei se é uma valeta que fosse maior para comportar todo esse lixo, já que temos uma usina, que fosse todo o lixo para lá, é a parte que eu vejo que poderia ser melhorado, no mais está tudo muito bem ${ }^{S 16}$.

A minha crítica é a falta de um profissional dessa área mesmo, para estar acompanhando essa usina, estar supervisionando e tomando conta desse processo de perto. Quanto aos funcionários que estão lá, esse pessoal de apoio são profissionais muito comprometidos, gostam muito do trabalho. Tudo é favorável a acontecer: a comunidade está começando a participar, sensibilizando, os setores da sociedade estão mobilizados, agora, se não houver o contrato de um profissional corre o risco de novamente desabar este projeto, é como se fosse um hospital sem médico ${ }^{513}$. 


\section{Análise da questão 5}

As melhorias relacionadas nos discursos do sujeito coletivo, obtidas das entrevistas, referem-se tanto à sensibilização, como às questões operacionais da usina e da infra-estrutura para o manejo dos resíduos sólidos. Além dessas, foi abordada a questão do emprego, havendo uma cobrança no sentido de que o projeto deveria também se preocupar com isso.

Quanto à sensibilização da comunidade para a coleta seletiva, foram abordados os seguintes aspectos:

- Divulgar mais o projeto nas ruas, residências e no comércio para que ninguém esqueça que existe a Usina Simplificada de Reciclagem e Compostagem, em Mucugê. A divulgação poderia ser através de peças de teatro em praça pública e a criação de jingles para ser veiculado pelo carro de som.

- Colocar cartazes na rua para que a coleta seletiva esteja sempre presente no cotidiano das pessoas.

- Reuniões com a comunidade em geral e, especificamente, com as donas de casa.

- Utilizar os alunos da escola para mobilizar a população.

- Campanhas de divulgação do projeto junto aos turistas.

- Promover exposição dos materiais reciclados.

- Oficinas de arte com material proveniente do lixo promovendo sua comercialização.

- Distribuir prêmios entre as pessoas que participam de forma adequada na coleta seletiva.

Em relação à questão operacional, há um destaque para a falta de um gerente com capacitação adequada para gerir todo o processo. A própria técnica da CAR, em sua entrevista, chama atenção sobre este ponto, uma vez que o profissional para preencher esse cargo é nomeado pela administração municipal e, muitas vezes, se dá por indicação política, não atendendo ao perfil técnico adequado. 
Pelas observações realizadas, e pelos relatos de diversas pessoas com conhecimento sobre o projeto da Usina de Reciclagem e Compostagem, esta comporta a produção do lixo da cidade. Houve um problema inicial na Usina quando as valas projetadas para receber o refugo não suportaram sua produção devido a má segregação dos resíduos na mesa de catação, e por parte da comunidade.

Quanto à questão dos recipientes para receber o lixo seletivo, observa-se que, na cidade, apenas no local onde se realiza a feira semanal há um conjunto de acondicionadores para a coleta seletiva. Nas escolas do município, não foi observada a presença desse tipo de coletor, havendo reclamação dos professores sobre esse fato.

Para alguns sujeitos, o projeto está caminhando satisfatoriamente, e há recomendações para que ele seja estendido para outras cidades.

\subsubsection{O Discurso do Sujeito Coletivo sobre a relação pessoal com o lixo}

Da pergunta "lixo, você tem alguma coisa a ver com isto?" foi possível observar três idéias centrais, a saber:

a. Eu tenho a ver com o lixo porque o lixo vem da gente (eu produzo);

b. Tenho e devo manejá-lo adequadamente;

c. Não tenho nada a ver com o lixo.

\section{Idéia Central: Eu tenho a ver com o lixo porque o lixo vem da gente (eu} produzo)

\section{DSC 1}

Acho que todo mundo tem a ver com o lixo, lixo não vai nascer, não é planta para nascer, então vem da gente ${ }^{S 2}$. Lixo é aquilo que não serve mais para a gente, não tem utilidade nenhuma. Nem sempre... tem as coisas que jogam no lixo que tem utilidade para outras pessoas ${ }^{55}$. Como todo mundo, eu também uso as coisas que preciso e as que não preciso vou jogar no lixo ${ }^{51}$; a gente sempre tem a ver, nós somos consumidores ${ }^{517}$. A gente mexe com isto o tempo todo, tem papel e tem que retirar a sujeira de casa e a gente sempre tem a ver com o lixo por causa disto ${ }^{58}$. A gente, no dia a dia, acaba produzindo muito lixo, não deveria, mas o consumo 
humano, ultimamente, tem sido exagerado, apesar de que hoje eu tento diminuir ele. Por exemplo: as sacolas que vêm do mercado se transformam em sacola para colocar o próprio lixo. Muitas vezes, o lixo sofre uma transformação e pode até voltar para a minha casa. Sai umas latinhas, papel, papelão como lixo mas, de repente, olha eu lá na frente trazendo ele de volta transformado, podendo me servir ainda e a outras pessoas ${ }^{S 13}$. Então, eu tenho muito a ver com o lixo e tenho que aprender muito mais a lidar com o lixo e a nâo produzir tanto ${ }^{513}$. Se tiver lixo a gente tem que fazer alguma coisa, se a gente não jogasse o lixo na rua, se a gente separasse o lixo, se a gente não jogasse nos pontos turisticos quando a gente fosse passear não teria lixo. Então todos têm a ver um pouquinho com issos2.

\section{Idéia Central: Tenho e devo manejá-lo adequadamente}

\section{DSC 2}

Todos nós temos ${ }^{S 3, S 6, S 9, S 14, S 15, S 16}$. No meu trabalho e em casa ${ }^{S 6}$, o lixo faz parte da nossa vida ${ }^{S 3}$, somos produtores de lixo ${ }^{\text {SI4 }}$. Na nossa casa, todo dia nós temos lixo, mas sabendo utilizá-lo, reutilizá-lo, organizá-lo e colocar este lixo no lugar certo e direcionar o que não poder ser utilizado, ele nunca vai nos aborrecer, nos atrapalhar ${ }^{516}$. Então, o lixo faz parte do nosso dia a dia ${ }^{S 3}$. Se não tem como separar, então é saber trabalhá-lo e colocá-lo em local adequado ${ }^{53}$, mas para isto, nós temos que educar os outros a fazerem a mesma coisa ${ }^{\text {sib }}$, orientar as pessoas sobre o lixo, sobre a separação ${ }^{S 15}$. Aqui é muito lixo, inclusive o pessoal estava reclamando que a gente não está separando, mas a gente produz bastante. Mas no caso, o erro é da gente, porque quem tem que estar separando e deixando tudo organizado é a gente ${ }^{S 9}$. A gente olha os quintais, nas ruas, quando a gente vê lixo a gente entra em contato com a prefeitura porque nesse ponto eles apóiam a gente ${ }^{S 15}$. Então, eu tenho muito a ver porque não adianta a gente reclamar, a gente, quando troca de pessoa que mora com a gente, vê que ela descasca uma laranja e joga no quintal, então lixo é lixo e tem que ser posto no lixo para dar certo ${ }^{\text {sl6 }}$. Reciclando o

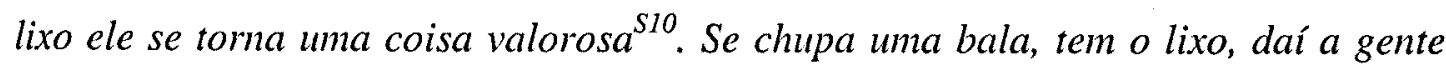
tem que procurar uma lixeira para não sujar a cidade, para não poluir o ambiente. O melhor é a gente recorrer a uma lixeira mais próxima e até mesmo colocando no 
bolso para não sujar a rua e manter a cidade limpa. Aqui, muitas pessoas fazem isto. Às vezes, chega em casa e está com o bolso cheio de lixo para não jogar na rua e ajudar na limpeza da cidade ${ }^{S 17}$.

Hoje se você passa aqui e joga uma latinha todo mundo fica de olho, vai lá e pega ou diz que tem uma lixeira logo ali. Eu ajudo no que puder: não jogo lixo no chão, não abro a porta do carro para jogar lixo no chãost. Porque vamos supor,se eu não faço, não posso cobrar de meu vizinho. Mas o lixo, em si, a gente faz a seleção da melhor maneira possível e eu, como um dos produtores de lixo, cobro da minha esposa è dos meus filhos para que façam direito, para ver isto ir para a frente $^{S 14}$.

\section{Idéia Central: Não tenho nada a ver com o lixo}

\section{DSC 3}

Não, o que gera aqui é muito pouco e pode ser reaproveitado.

\section{Análise da questão}

Percebe-se, nos discursos referentes à relação das pessoas entrevistadas com o lixo, que o ser humano é responsável pela geração do lixo e que está vinculado com o consumo de cada um. As pessoas, que dizem ter a ver com o lixo, demonstram um senso de responsabilidade quanto à diminuição da produção de resíduos e à possibilidade de seu reaproveitamento.

No entanto, para um grupo de pessoas, o lixo depois de gerado e descartado em uma lixeira (separado ou não), deixa de ser um problema. Neste contexto, a questão dos resíduos sólidos é solucionada apenas pelo seu manuseio correto. Há pessoas que consideram que não tem nada a ver com o lixo pelo fato de sua produção ser pequena e, também, porque os resíduos podem ser reaproveitados. Para este grupo, a resolução da problemática do lixo é simplista, basta manejá-lo adequadamente após sua geração, não passa pela reflexão sobre o consumo e sobre o desperdício. 


\subsection{Conclusão}

Os projetos de Educação Ambiental e da Usina Simplificada de Reciclagem e Compostagem de Mucugê foram concebidos e implementados por um órgão do Governo do Estado da Bahia (CAR). Foi implantado como um projeto piloto devido às características locais: cidade turística, inserida dentro do Parque Nacional da Chapada Diamantina e que possuía um veículo coletor de lixo.

A prática de Educação Ambiental realizada como suporte para a implantação do projeto de coleta seletiva foi baseada na mudança de comportamento e na corrente do "desenvolvimento sustentável". A participação da comunidade no projeto deu-se por meio da separação do lixo na fonte geradora, e na aquisição de hábitos para a conservação da limpeza da cidade. No projeto e na construção da usina, não houve participação da comunidade e esse fato está representado nos discursos pela fala: "nós ganhamos a usina".

No projeto inicial de Educação Ambiental, foram utilizadas, para a sensibilização da comunidade, palestras e reuniões com segmentos da sociedade local, e também atividades realizadas por professores e alunos da escola estadual, técnicas que tiveram repercussão positiva junto aos moradores de Mucugê.

A concepção da formação de uma rede de mobilização e interação entre grupos representativos da comunidade, como objetivo do projeto de Educação Ambiental para o relançamento da coleta seletiva, é interessante. Contudo, observase que essa idéia foi lembrada, apenas, por um dos grupos da rede e, mesmo esse grupo não estava em atividade na época das entrevistas. Supõe-se que o motivo se encontra na dificuldade de formação de líderes de grupo para o seguimento do trabalho de mobilização. Para isto, o projeto deveria ter previsto um curso de Educação Ambiental para a formação de educadores ambientais locais com a tarefa de mobilização, a longo prazo, não só voltado para a questão dos resíduos sólidos, como para outros problemas ambientais locais. Observa-se também que os moradores valorizam sua cidade, dando ênfase maior à sua beleza natural e à sua limpeza. Esse fato deve ser incentivado e ser contemplado pelas atividades de Educação Ambiental para promover a subjetividade coletiva e tornar pertencentes à comunidade local projetos que visem à melhoria das questões ambientais. A mostra 
de reciclagem de resíduos (de papel reciclado, de compostagem e de confecção de brinquedos) chamou a atenção, contudo foi uma atividade pontual e não se observou sua continuidade, com grupos locais trabalhando diretamente nessas atividades.

A implantação da Usina Simplificada de Reciclagem e Compostagem foi percebida como um fator importante na limpeza da cidade e na diminuição da proliferação de vetores do lixo, entendida como uma alternativa de destino adequado para os resíduos sólidos urbanos gerados pela comunidade.

Os motivos da interrupção do funcionamento da usina, após 13 meses, não são claros para a população. Infere-se que foi devido à mudança da administração municipal em virtude da realização de novas. Não foi observada uma cobrança por parte da comunidade pela sua continuidade. Segundo os moradores, antes da parada da usina, o lixo já não estava sendo segregado corretamente, pois ninguém exigia mais essa prática.

Dos discursos analisados, dois fatores foram apontados como importantes, para o sucesso do gerenciamento do lixo: primeiro, a sensibilização da comunidade para a coleta seletiva e o segundo, relacionado com a operação da Usina. Em relação ao primeiro é indicado que a mesma deve ser assumida por pessoas com qualificação técnica em manejo de resíduos sólidos; na sensibilização é dada importância da rádio para informação e divulgação de assuntos locais e que não está mais em funcionamento. Também o carro de som é pouco utilizado na informação da coleta seletiva. Como a usina fica afastada do centro da cidade as pessoas "esquecem que tem a usina" e portanto a promoção de visitas à usina que poderia ser utilizada como uma atividade de sensibilização da comunidade, não é explorada.

A Escola foi lembrada como fator importante no processo educacional realizado na primeira fase do projeto. Foi a Escola quem planejou e executou, através de seus professores e alunos, a "gincana" e o "dia da faxina". Também foram os alunos que distribuíram, porta a porta, os panfletos explicativos do projeto. Outro fator relatado, segundo o coordenador local do projeto de Educação Ambiental, foi que o projeto suscitou a ofertas das disciplinas diversificadas Turismo e Jornalismo, no ensino médio e fundamental, contemplando as questões ambientais. Os alunos dessas disciplinas foram responsáveis por programas na rádio comunitária local, que, 
na época das entrevistas, tinha sido fechada estava fechada por estar ilegal junto à Agência Nacional de Telecomunicações.

Para atingir as turistas que se deslocam até a cidade de Mucugê, devem ser desenvolvidas atividades educacionais e informações sobre a forma de manejo do lixo nesta cidade.

Observa-se em Mucugê, que o lixo tem as seguintes representações:

- Representação do lixo como parte da vida dos seres humanos: as pessoas percebem que não existe a possibilidade de geração zero, pois é um dos subprodutos das atividades humanas.

- Representação do Lixo que não é lixo: essa representação indica que o lixo pode ser reaproveitado/reciclado. Também, se o mesmo for manuseado corretamente, não haverá lixo, nem aborrecimentos. Mas, para isto, é preciso de educação. 


\section{CONSIDERAÇÕES FINAIS E RECOMENDAÇÕES}

No desenvolvimento da pesquisa, procurou-se registrar os métodos utilizados e cruzar os dados obtidos pelas observações de campo, pelos documentos escritos e por meio de depoimentos de pessoas responsáveis pelos projetos, com os dados obtidos nos Discursos do Sujeito Coletivo (DSC), para assegurar que, na análise e interpretação dos resultados da pesquisa fossem minimizados as tendências do pesquisador. Contudo, conforme ROCHE (2002), "é cada vez mais aceito, tanto dentro como fora do laboratório, que o ato em si da medição pode modificar o resultado pois é extremamente difícil para o pesquisador permanecer distante ou independente do processo a qual está pesquisando". Algumas questões que podem ter sofrido a influência do pesquisador estão relacionadas à amostragem, à coleta de dados através das entrevistas e na própria formação e interpretação dos DSC.

No caso da amostragem (amostra intencional), procurou-se incluir no universo dos sujeitos entrevistados, diferentes grupos de pessoas que pudessem informar sobre o fenômeno estudado. Foram incluídas pessoas com amplo conhecimento sobre o projeto e também sujeitos que, a priori, julgou-se terem pouco conhecimento ou pouca participação nos projetos avaliados. Entretanto, pode ter ocorrido a exclusão de sujeitos com ponto de vista diferente daqueles encontrados na pesquisa. Do ponto de vista do processo de representações sociais, "um sujeito é um sujeito social, sendo assim, não é o indivíduo isolado que é tomado em consideração mas sim as respostas individuais enquanto manifestações de tendências do grupo de pertença ou de afiliação na qual os indivíduos participam" (SPINK 1995, p.120).

Quanto à utilização da entrevista como uma das formas de coleta de dados algumas questões podem ser levantadas, conforme ROCHE (2002), GIL (1991) e TRIVINOS (1987): a falta de motivação do entrevistado para responder as perguntas formuladas; a inadequada compreensão dos significado das perguntas; o fornecimento de respostas falsas, determinadas por razões conscientes ou inconscientes; e a influência exercida pelo aspecto pessoal do entrevistador sobre o entrevistado.

Esse último aspecto pode ter influenciado nas respostas dos professores e funcionários da UEFS, bem como no Arraial de São Francisco da Mombaça devido 
ao fato de a pesquisadora ter um envolvimento direto nos projetos desenvolvidos nesses locais. Neste contexto, o entrevistado pode ter se sentido pouco à ao responder as questões propostas. Da mesma forma em Mucugê, os indivíduos entrevistados, talvez, sentiram-se "fiscalizados" pelo Poder Público, uma vez que o projeto é desenvolvido pela prefeitura municipal, mesmo tendo-se assegurado o anonimato através da assinatura do termo de consentimento.

A interpretação dos Discursos do Sujeito Coletivo foi, segundo SPINK (1995), "o olhar possível" da pesquisadora, a luz de seu conhecimento teórico e de sua experiência profissional e de vida. "A interpretação é regida, sem dúvida por opções teóricas que antecedem e mesmo determinam as interpretações. Já a validade pertence à esfera da intersubjetividade; não na busca do consenso acalentador mas na busca constante da contradição criativa" (SPINK 1995, p.142).

Neste sentido, levando em conta essas limitações, pode-se inferir que as comunidades dos locais onde foram desenvolvidos os projetos de Educação Ambiental, tendo como foco o gerenciamento dos resíduos sólidos urbanos, têm conhecimento sobre esses projetos. No município de Mucugê e na Universidade Estadual de Feira de Santana, a prática de Educação Ambiental realizada como suporte para a implantação do projeto de coleta seletiva foi baseada na mudança de comportamento e na corrente do "desenvolvimento sustentável". A participação da comunidade, no projeto, deu-se por meio da separação do lixo na fonte geradora. No projeto e na construção da Usina Simplificada de Reciclagem e Compostagem, não houve participação da comunidade e esse fato está representado nos discursos pela fala: "nós ganhamos a usina". Tanto em Mucugê, como na UEFS, as ações educacionais desenvolvidas são mais voltadas para a mudança de comportamento individual.

O projeto de Educação Ambiental desenvolvido no Arraial de São Francisco da Mombaça está inserido no contexto da chamada "sociedade sustentável". Isso porque, ao longo do processo, houve a formação de parcerias, tanto local com a criação da Associação Comunitária do Arraial de São Francisco da Mombaça, como com Universidades, com a Rede de Leitura (Comitê de Salvador) e com Prefeituras. Também houve a valorização da identidade comunitária, através do resgate da cultura local. 
Percebeu-se que a sustentabilidade dos projetos, ao longo do tempo, foi um problema nas três experiências estudadas. Na UEFS, embora o processo não tenha sofrido descontinuidade, houve uma redução na quantidade dos resíduos recicláveis coletados, sendo que o impacto inicial do projeto, tanto para professores com mais de dez anos na UEFS, quanto para alunos com vivência menor que cinco anos, enfraqueceu ao longo do tempo, e a adoção de um novo comportamento foi transitória, voltando ao inicial. A explicação para isso pode estar na forma como se realizaram as ações educacionais, que se tornaram rotineiras, levando ao empobrecimento da percepção e da necessidade de participação. Também essas ações não conseguiram envolver a comunidade universitária de forma a perceber que o projeto, também lhe pertence.

Em Mucugê, o projeto da Usina Simplificada de Reciclagem e Compostagem de Lixo parou de funcionar após dois anos da implantação do projeto. Pelo observado, não houve protesto da população, uma vez que a coleta (não seletiva) continuou sendo realizada. Nesse contexto, o lixo produzido nas residências não causou transtornos, e o tratamento e a destinação dada ao resíduo não preocuparam as pessoas. Observou-se que não existiu clareza, na comunidade, quanto ao real motivo da paralisação da Usina, podendo-se inferir que a coleta seletiva não foi incorporada como uma nova atitude, mas, sim, como algo imposto por alguém e, no momento em que não houve cobrança, o lixo deixou de ser segregado na fonte geradora. Este fato também pode ser um indicativo de que o programa de educação ambiental não conseguiu construir o "desejo do novo" na comunidade, isto é, aquilo que era esperado pelos técnicos da CAR e pela prefeitura naquele momento. Spossati, comentando sobre a descontinuidade de projetos na prefeitura de São Paulo, observa que "é fundamental, na atuação em comunidade, a construção da subjetividade coletiva, pois, quando esse processo não ocorre, a alteração pretendida não alcança o imaginário coletivo, o desejo da sociedade e, conseqüentemente, tornase descartável” (SPOSSATI 2001, p. 25).

Portanto, a prática educacional baseada na mudança de comportamento (prática linear: informação = mudança de comportamento) e observada nos projetos de Educação Ambiental desenvolvidos, tanto na UEFS, como em Mucugê, pode ter ser sido transitória, não atingindo a subjetividade dos moradores. 
O projeto desenvolvido no Arraial de São Francisco da Mombaça para resolução do problema do lixo local foi planejado e executado, participativamente, pela articulação da Associação com universidades e Poder Público. Neste caso, a interrupção do processo da coleta seletiva aconteceu pela fragilidade do elo entre a Associação Comunitária local e a Prefeitura. Esta não cumpriu a sua parte, que era a de coletar os resíduos nos períodos e forma determinados pelo projeto. Esse fato é uma das frustrações observadas na comunidade e, conforme apresentado em discurso, pode passar a idéia de que as necessidades da comunidade "só podem ser satisfeitas através do Poder Público". Contudo, observa-se que a idéia concebida para a resolução do lixo local continua presente nos discursos dos sujeitos da localidade.

Pelas implicações ambientais e de saúde que o manejo inadequado dos resíduos sólidos promove, a resolução desse problema deve ser uma preocupação dos diversos setores da sociedade. Nesse sentido, a Constituição Federal, no seu artigo 25, diz que todos tem direito ao Meio Ambiente ecologicamente equilibrado e que impõe-se ao Poder Público e a coletividade o dever de defendê-lo e preservá-lo para as presentes e futuras gerações. É dito também, que a efetividade desse direito é assegurada pelo Poder Público por meio de várias incumbências, entre as quais a promoção da Educação Ambiental e a exigência do prévio Estudo de Impacto Ambiental de atividades de significativa degradação do Meio Ambiente.

Em relação às competências, cabe à União e ao Estado traçar diretrizes gerais sobre resíduos sólidos e ao município legislar sobre assuntos de interesse local, e a questão dos resíduos sólidos é assunto de interesse local. Nesse contexto, o município, além de legislar, é responsável pela execução dos serviços de limpeza pública, dentre os quais estão: coleta, tratamento e disposição final dos resíduos sólidos. Além disso, cabe ao Poder Público Municipal informar adequadamente a população sobre suas atividades de limpeza pública, promover a participação da comunidade na tomada de decisões sobre a gestão dos resíduos sólidos urbanos, a Educação Ambiental e os estudos de Impacto Ambiental. À população cabe fiscalizar as atividades públicas, minimizar e acondicionar adequadamente seus resíduos sólidos, como também a conservação dos logradouros e terrenos baldios e facilitar a execução dos serviços de limpeza pública. 
Com referência às mudanças proporcionadas pelos projetos, os sujeitos declararam, nas três experiências avaliadas, que foram influenciados pelo projeto na mudança de hábitos no descarte do lixo (não jogar lixo no chão) e que sentem incomodados com a ausência de lixeiras em locais de circulação pública. Os projetos serviram, também para solidificar a consciência ambiental que algumas pessoas já possuíam antes de entrar em contato com os mesmos. Também percebe-se nos discursos do sujeito coletivo que houve melhoria na limpeza e na beleza das localidades em estudo. Em Mombaça, há observações no sentido do embelezamento da cidade pela construção e manutenção de jardins pelas próprias pessoas da localidade. As mudanças observadas relacionadas à limpeza e a estética local, em função do gerenciamento adequado do lixo urbano, são importantes indicadores da salubridade ambiental e que interferem positivamente na saúde pública

No Arraial de São Francisco da Mombaça, as mudanças pessoais observadas nos sujeitos foram mais além daquelas citadas acima, pois aconteceram, também, no campo do empoderamento individual, pois muitos deles relatam que voltaram a estudar, melhoraram no relacionamento interpessoal, sentem-se mais à vontade em expressar seus pontos de vista. A frase presente em um dos discursos ilustra esse fato: "As pessoas aprenderam a ter esperança, acreditar que o que sabe, mesmo não tendo nível superior, é capaz de mudar a história".

$\mathrm{O}$ discurso dos sujeitos que declaram que o projeto não lhes proporcionou mudanças (Mombaça e Mucugê) está alicerçado no argumento de que o mesmo deveria gerar trabalho e renda. Em Mombaça, houve, por parte da Associação, tentativas nesse sentido, ao se encaminhar pessoas da comunidade para cursos de capacitação, contemplando as potencialidades locais, como a fabricação de doces caseiros. Alguns entraves têm sido observados, como a comercialização, a padronização e a qualidade desses produtos para que possam atender o mercado. Algumas pessoas da comunidade têm obtido recursos financeiros através da comercialização do papel reciclado e do adubo proveniente da compostagem. Em Mucugê, não emergiu do projeto qualquer atividade que contemplasse essa questão.

Interessante observar os discursos sobre a participação dos sujeitos nos projetos. Para determinadas pessoas, sua participação significa segregar e acondicionar os resíduos sólidos conforme determinado pelo projeto. Essa forma de 
pensar está relacionada com a concepção de cidadania, no sentido de cumprir deveres e exigir direitos. Contudo, se considerarmos a participação, conforme SAWAIA (2001), como potência de ação, em termos de se passar da passividade, para a atividade, e de ser afetado pelo outro, a participação deveria ir mais além e ser como percebida nos discursos das pessoas que declaram que deve haver um envolvimento maior com o projeto, ou seja: fazer parte de um grupo ou associação, participar de reuniões e discussões, promover a sensibilização, a divulgação e a orientação, entre outros citados. "Participar é estar constante com os outros" conforme discurso de uma pessoa da comunidade que diz não ter participado do projeto. As pessoas envolvidas demonstram um sentimento de orgulho e declaram sentimentos positivos para que o projeto tenha êxito.

As formas de sensibilização dos projetos de Educação Ambiental desenvolvidos nos locais analisados foram as mais diversas. Na UEFS, pelas características especiais, onde é renovada parte da população a cada semestre letivo pelo ingresso de novos alunos, bem como pela rotatividade dos funcionários responsáveis pela limpeza do campus, há uma preocupação em informar esse público sobre a forma de gerenciamento do lixo desenvolvido na Universidade, através de palestras, informações em salas de aula, distribuição de material informativo e com cartazes espalhados pelo campus, sendo esta última, a forma de conhecimento sobre o projeto mais citada pelos entrevistados, além dos acondicionadores coloridos instalados em locais de circulação no campus. Observou-se que as mensagens contidas na maioria do material informativo utilizado, tanto na UEFS como em Mucugê, têm caráter normativo e, embora devam ser utilizados, não levam as pessoas a refletir sobre a problemática dos resíduos sólidos urbanos no contexto do modelo desenvolvimentista adotado nos países capitalistas, quanto à degradação ambiental e à saúde pública. Também não cria, segundo VIEZZER (1996), uma relação empática tão necessária ao aprendizado podendo ser percebido como uma imposição conforme o declarado por um sujeito - "parece uma lavagem cerebral" ou, "a coleta seletiva não deve ser imposta".

Observou-se que, nos discursos dos indivíduos de Mucugê e do Arraial de São Francisco da Mombaça, estão referências às atividades educativas mobilizadoras que permitiram a participação de muitas pessoas, como "mutirões de limpeza" e 
gincanas realizadas em Mucugê ou a caracterização dos resíduos e implantação da praça Terra Viva realizadas, respectivamente, nessas localidades.

A tentativa de mobilizar a comunidade de Mucugê por meio de formação de redes locais, é uma idéia interessante, contudo foi pouco lembrada nos discursos. Supõe-se que o motivo para a sua não viabilização esteja na dificuldade de formação de líderes locais para dar seguimento ao trabalho.

O lixo, enquanto resultado de todas as atividades humanas, é uma problemática presente em todos os segmentos sociais. Porém, a forma de percebê-lo no ambiente e a ação em torno dele são diferenciadas. Dos projetos analisados, nesta pesquisa, observam-se as seguintes representações:

- A representação do lixo que não é lixo: as pessoas têm a percepção de que, no lixo, tem "coisas boas" que podem ser transformadas. A idéia da reciclagem está fortemente presente como solução do problema. Infere-se que essa forma de pensar está relacionada com os programas veiculados pela mídia em geral e, também, com as atividades de educação ambiental que utilizam a reciclagem como forma de sensibilização quanto à questão dos resíduos sólidos.

- Representação do lixo como fonte de renda: a população observa que é possível obter emprego e renda através da comercialização direta do material possível de ser reciclado (vidro, metal, plástico, papel e outros com demanda de mercado), pela comercialização do composto orgânico proveniente da compostagem dos resíduos orgânicos e, também, pela sua utilização em horticultura. Bem como com a comercialização de papel proveniente da reciclagem artesanal e com a confecção de brinquedos de sucata. Inclui-se, também, nessa representação, o lixo como fonte de renda para a população informal dos catadores, visto como uma condição humana degradante e como um problema social no Brasil.

- Representação do lixo que não é problema: essa representação acontece quando os sujeitos eliminam os seus resíduos no âmbito de suas residências com a prática da queima ou do enterramento.

- Representação do lixo como parte da vida dos seres humanos: os sujeitos percebem que não existe a possibilidade de geração zero de resíduos, pois os 
mesmos são subprodutos das atividades humanas. Sentem-se incentivados a consumir e gerar resíduos devido à indústria de consumo. Para muitos, o acondicionamento e a coleta dos resíduos sólidos gerados são a solução para o problema.

- Representação do lixo como questão de cidadania: cada um deve ser responsável pela parcela de lixo que gera e pela limpeza do ambiente. Como o lixo faz parte do dia a dia dos seres humanos e é causador da degradação ambiental e de problemas de saúde, pode ser um bom gancho para se discutir o modo de vida da população, e temas que afetam a sociedade, relacionados a educação, ao saneamento, a pobreza.

$\mathrm{Na}$ maioria das representações sobre o lixo, observa-se, pouco, a questão da minimização dos resíduos, estando muito presente a questão de sua reciclagem. Nesse contexto, é importante que, nos programas de Educação Ambiental, sejam observados esses aspectos e suscite, no público alvo, a representação do lixo como questão de cidadania, para que a reciclagem não seja apresentada como a única solução do problema.

Além disso, quando do desenvolvimento dos temas, sustentabilidade, participação, Educação Ambiental, chegou-se à conclusão de que o gerenciamento de resíduos sólidos urbanos para sociedades sustentáveis deve estar baseado nos seguintes princípios:

- Princípio de precaução;

- Princípio da responsabilidade social;

- Princípio da inclusão social;

- Princípio da participação popular;

- Princípio de responsabilidade política;

- Princípio de utilização de tecnologias apropriadas;

- Princípio da sustentabilidade ecológica e ambiental;

- Princípio da universalidade e eqüidade dos serviços públicos de coleta, tratamento e disposição final dos resíduos não evitáveis;

- Princípio da cooperação;

- Princípio da sustentabilidade financeira;

- Princípio do conhecimento. 
Para se incorporarem esses princípios aos projetos de Educação Ambiental voltados para o gerenciamento de resíduos sólidos urbanos, sua prática deve estar alicerçada nos valores que promovidos pela Agenda 21: parceria, solidariedade e cooperação entre diferentes segmentos sociais. Devem, também, ter como objetivo a mudança de sensibilidade da sociedade, promovendo o pensamento sistêmico e uma abordagem holística dos problemas (CRESPO, 1997) para a construção de sociedades sustentáveis (SORRENTINO, 1995; DIEGUES, 1996).

Para isso, e levando-se em conta que, "desde o início da construção de um projeto, o mesmo seja estrategicamente pensado sob a vertente do impacto do conhecimento voltado não para o fim, mas para a continuidade e para o processo que poderá desencadear" (SPOSSATI, 2000 p. 13), acredita-se que os projetos de Educação Ambiental voltados para o gerenciamento dos resíduos sólidos urbanos devem levar em conta os seguintes subsídios metodológicos:

Campanhas de sensibilização: levadas por meio de palestras, reuniões, apresentação de vídeos e material impresso e debates com a comunidade abordando os aspectos da realidade local e global, legislação pertinente, as causas da geração dos resíduos sólidos, como também as conseqüências de seu manejo inadequado para a saúde e para o ambiente. Os textos utilizados devem contemplar: "a contextualização histórica e social do discurso; sobre os efeitos provocados por decisões e atitudes; promover a reflexão que leve a uma consciência do problema; e à apresentação de propostas e soluções" (TRAJBER e MANZOCHI, 1996 p. 32).

Planejamento participativo: sendo um dos instrumentos de participação, será importante para detectar problemas, propor soluções. Esses aspectos são facilitadores da autopromoção para direcionar políticas sociais centradas nos próprios interesses e na satisfação de suas necessidades DEMO (1999). Importante observar que a prática da solução proposta deve ser incentivada e viabilizada para dar maior credibilidade ao processo e conquistar mais a participação comunitária.

Incentivo à formação de parcerias: entre os diversos setores da sociedade tanto local como estadual, nacional e global. A formação de parcerias permite que a comunidade entre em contato com outras experiências e vivências vislumbrando as possibilidades de mudança. Mombaça é um exemplo disto: através das parcerias 
conquistadas, houve promoção de viagens de intercâmbio, cursos, e possibilidade de conhecer novas tecnologias para a resolução dos problemas demandados.

Promoção da identidade comunitária: através do resgate da cultura local e estimulo à organização social. A promoção da identidade permite ao grupo sentir-se comunidade e ter vida própria, sendo um agente facilitador da participação. Esse fato foi observado em Mombaça onde, através de oficinas, houve o resgate de cantigas antigas trazidas pelos moradores mais velhos, as quais, atualmente integram o repertório do Coral formado por jovens da comunidade. Esse fator também contribuiu para a interação entre jovens e adultos e, conseqüientemente, a participação de pessoas de todas as faixas etárias nas ações do projeto.

Utilização de instrumento de marketing: tanto para divulgar informações, como para compor a parte visual da infra-estrutura de coleta seletiva (acondicionadores, adesivos etc.). Utilizar os meios de comunicação adequados de acordo com a realidade local. Neste sentido, é importante observar como as lixeiras coloridas espalhadas no campus da UEFS chamam a atenção da comunidade universitária, e como a rádio comunitária de Mucugê foi lembrada como um importante meio de comunicação na divulgação do projeto.

Também é importante ressaltar que, nos projetos de Educação Ambiental para o gerenciamento de resíduos sólidos, devem ser previstos recursos financeiros para que o mesmo se mantenha por muito tempo, uma vez que mudança de paradigma é um processo longo.

Neste contexto, para a incorporação dos princípios de gerenciamento de resíduos sólidos para sociedades sustentáveis nas localidades estudadas devem ser observadas algumas questões. No caso do campus da Universidade Estadual de Feira de Santana, recomenda-se que o projeto de Educação Ambiental utilize as seguintes estratégias operacionais e educacionais:

- Estimular a inclusão da dimensão ambiental nos diversos cursos de graduação oferecidos pela UEFS;

- Proporcionar à comunidade universitária encontros sobre questões ambientais relevantes aos grupos envolvidos, preferencialmente no espaço da sede da EEA; 
- Realizar ações de sensibilização contínuas, renovadas e criativas dirigidas aos alunos ingressantes nos cursos de graduação;

- Atrair professores e alunos dos cursos noturnos oferecidos pela UEFS para que haja maior mobilização e participação desse público;

- Promover cursos e oficinas de capacitação de forma continuada para o pessoal responsável pela limpeza da UEFS;

- Desenvolver parcerias entre a EEA e os Diretórios Acadêmicos na promoção de discussões com os estudantes de todos os semestres sobre as questões ambientais;

- Incentivar a minimização de resíduos nos departamentos e setores administrativos (substituição de copos descartáveis, por exemplo);

- Reformular os conteúdos do material impresso, incentivando a reflexão sobre a problemática dos resíduos sólidos;

- Renovar a programação visual dos coletores e dos adesivos explicativos, necessários à coleta seletiva;

- Divulgar os resultados da coleta seletiva, do processo de gerenciamento do lixo na UEFS e das ações da Equipe de Educação Ambiental;

- Utilizar o espaço das cantinas para exposições do material reciclado confeccionado pela EEA e realizar oficinas de reciclagem de papel, nesses locais, semestralmente;

- Estimular visitas à sede da EEA para observação, in loco, das principais atividades relacionadas à recuperação dos resíduos sólidos coletados: o armazenamento dos recicláveis, a oficina de papel, a compostagem dos resíduos orgânicos;

- Cobrar, da Administração Superior, sua responsabilidade em relação à infraestrutura para a coleta seletiva;

- Incentivar a aquisição, pela UEFS, de materiais em que o fornecedor assuma a responsabilidade sobre os resíduos sólidos gerados após sua utilização ("toner" utilizado nas máquinas copiadoras, lâmpadas fluorescentes, reagentes para laboratórios, entre outros);

- Promover cursos de extensão universitária sobre gerenciamento de resíduos sólidos para sociedades sustentáveis abertos à comunidade em geral; 
- Desenvolver uma metodologia adequada para a caracterização do lixo aterro, de forma que seja um indicador da eficiência da segregação na fonte, por parte da comunidade universitária, para que, prontamente estratégias educacionais (mobilização, informação) sejam colocadas em práticas.

- Contemplar no gerenciamento do lixo os resíduos gerados nos laboratório e considerados perigosos, envolvendo todos os geradores no processo.

Sobre o projeto de Educação Ambiental desenvolvido em Mombaça, observase que o mesmo já apresenta certas características importantes quanto ao apregoado para a formação de sociedades sustentáveis. Para solidificar essas características, recomenda-se:

- Conceber um projeto de interesse da comunidade a fim de buscar recursos financeiros para sua implementação.

- Retomar o projeto de transformação dos locais utilizados para depósito de lixo em jardins.

- Promover encontros para a discussão do tema resíduos sólidos, com o enfoque sistêmico e com caráter histórico e social de sua produção, relacionando-os com o atual modelo de desenvolvimento.

- Fazer gestões junto à Prefeitura de Conceição do Almeida quanto à doação de terreno para a Associação, para construção de sua sede e, conseqüentemente, abrigar a oficina de papel e outras atividades do projeto.

- Promover cursos de capacitação em economia solidária.

- Escolher locais estratégicos para divulgação, por escrito, dos encontros da Associação Comunitária do Arraial e das atividades do projeto. Utilizar, também, o espaço das igrejas locais para essa divulgação.

- Incentivar a prática da compostagem doméstica.

Para o projeto de Educação Ambiental desenvolvido em Mucugê, recomendase:

- Promover um curso de Educação Ambiental para formação de educadores ambientais locais, para a sustentabilidade, com a tarefa de consolidar a rede de mobilização comunitária prevista no projeto de relançamento da usina. 
- Incentivar o resgate da cultura local. Observa-se, também, que os moradores valorizam sua cidade, dando ênfase maior à sua beleza natural e à sua limpeza. Esse fato deve ser incentivado, e contemplado nas atividades de Educação Ambiental para promover a subjetividade coletiva para tornar pertencentes à comunidade local projetos que visam à melhoria das questões ambientais.

- Incentivar a criação de oficinas de reciclagem (de papel reciclado, de compostagem e de confecção de brinquedos), inclusive, como forma de geração de emprego e renda.

- Contratar técnico especializado para o gerenciamento da Usina Simplificada de Reciclagem e Compostagem.

- Realizar campanhas de sensibilização rotineira para a comunidade em geral e para turistas.

Em geral, recomenda-se, para Programas de Educação Ambiental voltados para o Gerenciamento de Resíduos Sólidos para Sociedades Sustentáveis:

- A abordagem de assuntos referentes à reciclagem de materiais do lixo, embora importante, deve ser feita com cautela, pois enfatiza a solução após a geração do resíduo, contribuindo assim para consolidar o modelo de desenvolvimento atual (sociedade de produção e de consumo).

- As Escolas inseridas nas comunidades onde são desenvolvidos projetos de Educação Ambiental voltados para o tema Resíduos Sólidos podem ser parceiras importantes no processo de mobilização. Pois, além de difundir os objetivos do projeto, podem trabalhar o tema de forma transversal, suscitando trabalhos interdisciplinares.

- O acompanhamento, ao longo do tempo, da produção de resíduos (qualiquantitativamente), através da caracterização física dos mesmos, deve ser utilizada como um indicador do andamento da coleta seletiva. Também devese utilizar o cálculo da geração per capita e do índice de material reciclável segregado, como indicadores para subsidiar ações em torno da minimização de resíduos sólidos. 
- Observar a infra-estrutura para a coleta seletiva de lixo. Deve-se planejar e dimensionar adequadamente os coletores para o recebimento do lixo, promover uma coleta eficiente para que os resíduos segregados tenham uma destinação adequada, bem como mercado para absorvê-los.

- Prever para os projetos de Educação Ambiental para o gerenciamento de resíduos sólidos recursos financeiros para manter as atividades previstas.

- Promover atividades educativas mobilizadoras que permitiram a participação de muitas pessoas.

- Utilizar mensagens, no material informativo, que levem a comunidade a refletir sobre a problemática dos resíduos sólidos urbanos nos seus deferentes aspectos.

- Capacitar o pessoal envolvido nos programas em temas que levem em conta os princípio de sustentabilidade.

Recomenda-se também, que estudos sobre custos de coleta seletiva e Educação Ambiental incluindo todos os aspectos ambientais, ecológicos, sociais e econômicos sejam realizados.

Os projetos de Educação Ambiental voltados para o gerenciamento de resíduos sólidos urbanos devem ser incentivados. O tema "resíduos sólidos" pode promover o pensamento sistêmico ao mostrar interdependência entre a ação humana e a degradação do ambiente, e entre o caráter histórico e o social da produção de resíduos, relacionando-os com o atual modelo de desenvolvimento. Como também com os efeitos dos dois lados da cadeia produtiva (dos recursos naturais e o dos resíduos) observando-se a reciclagem nesse ciclo produtivo. Também, sendo o lixo inerente às atividades humanas pode suscitar, na discussão de sua problemática, outras questões que afetam a qualidade de vida das comunidades. A mobilização para a resolução do problema imediato - o lixo - pode ser uma forma de percepção do futuro. SANTOS (2000), ao discorrer sobre a neo comunidade afirma que: "neo comunidade transforma o local numa forma de percepção do global, e o imediato, numa forma de percepção do futuro". 


\section{REFERÊNCIAS BIBLIOGRÁFICAS}

1. ABNT, Associação Brasileira de Normas Técnicas. NBR 10.004. Resíduos Sólidos - Classificação. 1987.

2. ABNT, Associação Brasileira de Normas Técnicas. NBR 8.419. Apresentação de projetos de aterros sanitários de resíduos sólidos urbanos. 1992.

3. ABNT, Associação Brasileira de Normas Técnicas. NBR 8.848. Apresentação de projetos de aterros controlados de resíduos sólidos urbanos. 1985.

4. [Anonymus]. Comitê solicita correções dos resultados da PNSB. ABES Informa. 2002 set/out. Ano 9, n 09/10, p.4.

5. [Anonymus]. Todo processo educacional deve voltar-se para a realidade do público ao qual se destina. Ação Ambiental 1999 out/nov. Ano II, n 8:5-7.

6. ACASFMombaça, Associação Comunitária do Arraial de São Francisco da Mombaça. Os fios de nossa teia. 2000.

7. Almeida E S, Castro C G J, Vieira C A L. Distritos Sanitários: Concepção e Organização. São Paulo: Faculdade de Saúde Pública da Universidade de São Paulo; 1998.v.1, (Série Saúde e Cidadania).

8. Agenda 21. [documento on line]. Disponível em http://www.mma.gov.br [1997 Set 25].

9. Aguiar A. As parcerias em Programas de coleta seletiva de Resíduos Sólidos Domésticos. São Paulo; 1999. [Tese de Mestrado - Faculdade de Saúde Pública da USP].

10. Aragão I, Campos A C. Feira de Santana; 2002. Colégio Estadual Edvaldo Machado Boaventura: uma nova visão sobre os resíduos sólidos. [Monografia de Especialização do Curso de Especialização em Educação Ambiental para a Sustentabilidade da Universidade Estadual de Feira de Santana] 
11. Akutsu J. Resíduos de Serviços de Saúde: proposições de metodologias para análise de alternativa de sistemas de tratamento. São Carlos; 1992.[Tese de Doutorado - Universidade de São Carlos].

12. Barros R T. et al. Manual de Saneamento e Proteção Ambiental para os Municípios. Belo Horizonte:Escola de Engenharia da UFMG;1995.v.2.

13. Boff L. Saber cuidar. Ética do humano-compaixão pela terra. Petrópolis: Vozes; 1999.

14. Buarque C. Teoria Econômica e Meio Ambiente. In: Textos Básicos. $46^{\mathrm{a}}$ Semana Oficial da Engenharia, da Arquitetura e da Agronomia;1989 Nov 21-25; Salvador, Brasil;1989. p.65-80

15. BRASIL. Lei N. 9.795 , de 27 de abril de 1999. Dispõe sobre a educação ambiental. Institui a Política Nacional de Educação Ambiental e dá outras providências. Diário Oficial. (28/04/1999) Brasília, DF.

16. BRASIL. Portaria $n^{\circ}$. 53, de 1 de março de 1979. Estabelece normas aos projetos específicos de tratamento e disposição de resíduos sólidos, bem como a fiscalização de sua implantação, operação e manutenção. Ministério do Interior; Brasília.

17. Capra F. A Teia da Vida: uma nova compreensão científica dos sistemas vivos. São Paulo:Cultrix; 1997.

18. CAR, Companhia de Desenvolvimento e Ação Regional. "Programa de Mobilização e Aprendizagem para a Coleta Seletiva de Mucugê. Relançamento".2001.

19. CAR, Companhia de Desenvolvimento e Ação Regional. Programa de Educação Ambiental. Município de Mucugê. Avaliação. 1999.

20. Carvalho I C M, A invenção do sujeito ecológico: sentido e trajetórias em educação ambiental. Porto Alegre; 2001. [Tese de doutorado-Faculdade de Educação da UFRGS]

21. Castro R de. Educação Ambiental. In: Aragonés J e Amérigo M. Psicologia Ambiental. Madrid: Pirâmide;1998. p.329-351.

22. CGU/UNICAMP. Coordenadoria Geral da Universidade de campinas. Relatório, 2002. [documento on line]. Disponível em http://www.cgu.unicamp.br/residuos/proc.htm [2003 maio 13]. 
23. Chioro A, Almeida E S, Zioni F. Estado, Políticas Públicas e Sistema de Saúde: Antecedentes, Reforma Sanitária e o SUS. São Paulo; 1997. [Faculdade de Saúde Pública da USP. Texto preliminar].

24. Comissão Européia. A EU e a Gestão de Resíduos. Luxemburgo: Serviço das Publicações Oficiais das Comunidades Européias; 2000, 18 p.

25. Comissão Mundial sobre Meio Ambiente e Desenvolvimento. Nosso Futuro Comum. Rio de Janeiro:Fundação Getúlio Vargas;1988.

26. CONAMA, Conselho Nacional do Meio Ambiente. Subsídios Técnicos para Elaboração do Relatório Nacional do Brasil para o CNUMAD, Brasília: 1991.

27. Crespo S. Educação e Sustentabilidade na Agenda 21: O Papel da Educação Ambiental no Programa da Globalização. In: Cadernos do IV Fórum de Educação Ambiental/I Encontro da Rede Brasileira de Educação Ambiental. Coordenação Associação Projeto Roda Viva, Instituto Ecoar para a Cidadania, Instituto de Estudos Sócios-Econômicos - INESC. Rio de Janeiro: 1997.

28. Czapski S. A Implantação da Educação Ambiental no Brasil. Brasília: MEC;1998.

29. Demo P. Avaliação Qualitativa. São Paulo: Cortez; 1987.(Coleção Polêmicas de Nosso Tempo, 25).

30. Demo P. Política Social, Educação e Cidadania. Campinas: Papirus, 1996. 2ed.124p.

31. Demo P. Participação é Conquista. São Paulo: Cortez. 1999. 4ed. 176 p.

32. Dias G. Educação Ambiental. Princípios e Práticas. São Paulo: Gaia 4.ed; 1992.

33. Dias S M F. Nascimento $\mathrm{S}$, Reis $\mathrm{A}$, Diagnóstico dos resíduos sólidos produzidos no Arraial de São Francisco da Mombaça - Bahia: uma contribuição para o desenvolvimento sustentável da comunidade no projeto "Terra Viva - O Que Queremos" da Associação Comunitária Local. In: Anais do IX Simpósio Luso Brasileiro de Engenharia Sanitária e Ambiental; 2000; Porto Seguro. Rio de Janeiro: Associação Brasileira de Engenharia Sanitária e Ambiental.[CD-ROM] 
34. Dias S M F, Nunesmaia M F. Diretrizes para o gerenciamento de resíduos Sólidos em Cidades de Pequeno Porte. In: Anais do $8^{\circ}$ Congresso de Engenharia Sanitária e Ambiental; 1995; Salvador. Rio de Janeiro: Associação Brasileira de Engenharia Sanitária e Ambiental.[CD-ROM]

35. Dias S M F, Souza W. Compostagem doméstica uma forma de minimização de resíduos domésticos. In: Anais do I Congresso Nacional de Meio Ambiente na Bahia; 1998.Feira de Santana.

36. Dias S M F, Vaz L M S. Caracterização Física dos Resíduos Sólidos Urbanos: uma Etapa Preliminar no Gerenciamento do Lixo. In: Anais do XXVIII Congresso; 2002; Cancun. México: Associação Interamericana de Ingeniería Sanitária y Ambiental. [CD-ROM]

37. Diegues A C S. Desenvolvimento sustentável ou sociedades sustentáveis: da crítica dos modelos aos novos paradigmas. In: Diegues, A.C.S. Ecologia humana e planejamento em áreas costeiras. São Paulo: NUPAUB, 1996.

38. Ferreira J A. Lixo Hospitalar e Domiciliar: Semelhanças e Diferenças. Um Estudo de caso no Município do Rio de Janeiro. Rio de Janeiro; 1997. [Tese de Doutorado-Fundação Oswaldo Cruz, Escola Nacional de Saúde Pública].

39. Fórum Internacional de ONG's e Movimentos Sociais. Tratado sobre resíduos. Rio de Janeiro. 1992.

40. Franco A. Por que precisamos de Desenvolvimento Local Integrado e Sustentável. Nova versão, 2000. [documento on line]. Disponível em http://www.tu-

berlin.de/abz/netz/deutsch/stadtenwicklung/artlikel/franco/text.htm [2002 out 10]

41. Furtado A. Ecologia e Desenvolvimento: os desafios da atual crise Mundial. In: Ciência e Ambiente; 1991;3:15-29.

42. Gil A C. Método e Técnicas de Pesquisa Social. São Paulo:Atllas S A , $1991 ; 3$ ed.

43. Giulliani G.M. Sociologia e Ecologia: Um Diálogo Reconstruído. Rio de Janeiro: Dados; v.41 n. 1.1998. 
44. Gonçalves C W P. Meio Ambiente, ciência e poder: diálogo de diferentes matrizes de racionalidade. In: Ambientalismo e Participação na Contemporaneidade. Coordenação Marcos Sorrentino. São Paulo: EDUC/FAPESP, 2001. p.135-161.

45. Grimberg E, Baluth P. Coleta Seletiva: reciclando materiais, reciclando valores. São Paulo:UNICEF/Polis, 1998.

46. Guareschi P. "Sem Dinheiro não há Salvação": Ancorando o Bem e o Mal entre Neopentecostais. In: Guareschi P, Jovchelovitch S. Textos em Representações Sociais. Petrópolis: Vozes; 1998.p.191-225.

47. Guimarães R P. Aterrizando una cometa: indicadores territoriales de sustentabilidad. Revista Interamericana de Planificaciós (Cuenca, Ecuador), n 119-120, julio-deciembre 1998; p.7-58.

48. Günther W M R. Saúde Ambiental comprometida pelos resíduos sólidos. RESID'99: Seminário sobre resíduos sólidos. São Paulo: Associação Brasileira de Geologia da Engenharia, 1999; p. 83-89.

49. Günther W M R. Apostila sobre resíduos sólidos. São Paulo: 2000 [Faculdade de Saúde Pública da USP].

50. IBGE. Pesquisa Nacional de Saneamento Básico. 2000. Disponível em http://www.ibge.gov.br/home/estatística/populacao/condicaodevida/pnsb/lixo [2002 ago 12]

51. IPT/CEMPRE. Lixo Municipal: Manual de Gerenciamento Integrado. São Paulo:IPT/CEMPRE; 2000,2.ed.

52. Jaramillo J. Resíduos Sólidos Municipales. Guia para El Deseño, Construccion y operacion de Rellenos Sanitários Manuales. Colômbia, 1994.

53. Jovchelovith $S$. Vivendo a vida com os outros: intersubjetividade, espaço público e representações Sociais. In: Guareschi P, Jovchelovitch S. Textos em Repreentações Sociais. Petrópolis:Vozes; 1998.p.63-85.

54. Lefèvre F, Lefèvre A M C, Teixeira JJV. O Discurso do Sujeito Coletivo: uma nova abordagem metodológica em pesquisa qualitativa. Caxias do Sul:EDUCS;2000.

55. Leff E. Epistemiologia Ambiental. São Paulo: Cortez; 2001.240p. 
56. Machado P A L. Direito Ambiental Brasileiro. São Paulo: Malheiros; 1995.

57. Maturana H, Varela F. A Árvore do conhecimento. Campinas: Livraria, Editora e Promotora de Eventos; 1995.281p.

58. Medrado, H. Mucugê e sua História. Letera: Bahia, 1998, 109p

59. Michaelis: dicionário. [CD ROM]. Metron. São Paulo; 2002.

60. Minayo M S C. O desafio do Conhecimento. Pesquisa Qualitativa em Saúde. São Paulo/Rio de Janeiro:Hucitec/Abrasco, 1995.

61. Mir R C. Sistema Locales de Salud. Organización, regionalización, princípios generales. In: Paganini J M, Mir R C. Los Sistemas Locales de salud Conceptos - Métodos - Experiências. OPAS/OMS. Washington. 1990; n.519:p.117-135].

62. Monteiro J H P. Pesquisa Nacional de Saneamento Básico - PNSB 2000. Limpeza Urbana e Coleta de Lixo. In: ABES Informa. ABES: Rio de Janeiro; Ano 9, n 03/04, mar/abr 2002.

63. Moraes L R S. Gestão integrada e sustentável de resíduos sólidos urbanos: um outro paradigma. In: Anais do Seminário Nacional de Resíduos Sólidos; 2002; Gramado. Rio de Janeiro: Associação Brasileira de Engenharia Sanitária e Ambiental. [CD-ROM]

64. Moraes L R S, Menezes A L F. A participação social e a Educação Ambiental na política e gestão de recursos hídricos, saneamento e resíduos sólidos urbanos e a experiência do CELMM em Alagoas. In: Anais do Simpósio Recursos Hídricos do Nordeste 2002; Maceió. Porto Alegre: Associação Brasileira de Recursos Hídricos. [CD-ROM].

65. Moser G. Psicologia Ambiental no novo milênio: integrando a dinâmica cultural e a dimensão temporal. In: Tassara E (org). Panoramas interdisciplinares para uma psicologia ambiental do urbano. São Paulo: EDUC; FAPESP; 2001.

66. Nascimento Junior J. Relação entre a disposição dos Resíduos Sólidos e a Proliferação Aedes aegypti: um estudo epidemiológico. Brasília; 1999. [Tese de Mestrado da Universidade de Brasília].

67. Nascimento S C, Reis A, Campos D, Nóbrega N, Santos P. O olhar seletivo voltado à leitura, educação ambiental e cidadania. In: Anais do I 
Congresso Nacional de Meio Ambiente na Bahia; 1998; Feira de Santana. P.201-203.

68. Novo M. La educación ambiental. Bases éticas, conceptuales y Metodologicas. Madrid: UNIVERSITAS; S.A.1996.

69. Nunesmaia M F S. Lixo: Soluções Alternativas - projeções a partir da experiência UEFS. Feira de Santana: UEFS; 1997.

70. Öko-Institut e. V. Waste Prevention and Minimisation. Commissioned by the European Comission, DG XI. Darmstadt. Final Report, 1999. 119p.

71. OPA. Organização Panamericana da Saúde. Atenção Primária Ambiental.Waschington, D.C;1999.

72. Pereira Neto J T. Conceitos modernos de compostagem. Engenharia Sanitária. 1989; 28:105-109.

73. Quintas J L. Por uma educação ambiental emancipatória. In. Quintas J S (org) Pensando e Praticando a Educação Ambiental na Gestão do Meio Ambiente. Brasília: IBAMA; 2000. p.13-19.

74. Relatório de Atividades. $2^{\mathrm{a}}$ etapa. A Sombra de uma Jaqueira. Projeto Escola/Comunidade Rural/Cidadania. Associação Comunitária Arraial de São Francisco da Mombaça/Escola Rural Nicolau de Coni. Período: Agosto a dezembro de 1998. São Francisco da Mombaça, 1999.

75. Roche C. Avaliação de impacto de trabalhos de ONGs. Aprendendo a valorizar as mudanças. São Paulo:Cortez; 2002;2 ed. [edição adaptada para o Brasil:tradução Tisel Tradução e Interpretação Simultânea Escrita].

76. Rosen G. Uma História da Saúde Pública. Trad. de Marcos Fernandes da Silva Moreira. São Paulo: UNESP; 1994.

77. Sá R S. Núcleo central das Representações Sociais. Petrópolis:Vozes; 1996.

78. Sachs I. Estratégias de transição para o século XXI. In: Bursztyn, M (org). Para Pensar o Desenvolvimento Sustentável. Brasiliense, 1993.

79. Sachs I. Caminhos para o desenvolvimento sustentável. Rio de Janeiro: Daramond, 2000.

80. Santos B S. A crítica da razão indolente: contra o desperdício da experiência. São Paulo: Cortez, 2000. v.1. 
81. Scherer-Warren I. Movimentos Sociais e Participação. In: Ambientalismo e Participação na Contemporaneidade. Coordenação Marcos Sorrentino. EDUC/FAPESP: São Paulo; 2001. p 41-56.

82. Sawaia B. Participação Social e Subjetividade. In: Ambientalismo e Participação na Contemporaneidade. Coordenação Marcos Sorrentino. EDUC/FAPESP: São Paulo; 2001. p.115-134.

83. SEI. 2002 [Documento on line]. Disponível e http://www.sei.ba.gov.br/anuário.asp [2003jan13]

84. SEPLANTEC. Secretaria do Planejamento Ciência e Tecnologia. Estudo para a Implantação de Usina Simplificada de Reciclagem e Compostagem do Lixo - Município de Mucugê, BA. 1998a. 28 p.

85. SEPLANTEC. Secretaria do Planejamento Ciência e Tecnologia. Projeto. Usina de Simplificada de Reciclagem e Compostagem do Lixo do Município de Mucugê, BA. 1998b.

86. SEPLANTEC. Secretaria do Planejamento Ciência e Tecnologia. Usina Simplificada de Reciclagem e Compostagem do Lixo do Município de Mucugê, BA. Relatório final. 2000.

87. Shumacher E F. O Negócio é ser pequeno. Rio de Janeiro: Zahar; 1977.

88. Sorrentino M. Crise Ambiental e Educação. In. Quintas J S (org) Pensando e Praticando a Educação Ambiental na Gestão do Meio Ambiente. Brasília: IBAMA; 2000. p.95-104.

89. Sorrentino M. Educação Ambiental e Universidade: Um estudo de caso. São Paulo;1995. [Tese de Doutorado-Faculdade de Educação da USP].

90. Spossati A.Movimentos Utópicos da Contemporaneidade. In: Ambientalismo e Participação na Contemporaneidade. Coordenação Marcos Sorrentino. EDUC/FAPESP: São Paulo; 2001.p.11-39.

91. Spink M J. "Desvendando as teorias implícitas: uma metodologia de análise das Representações Sociais”. In: Guareschi P, Jovchelovitch S. Textos em Representações Sociais. Petrópolis: Vozes; 1995.p.191-225.

92. Tambellini A T, Câmara V M. A temática saúde ambiente no processo de desenvolvimento do Campo da Saúde Coletiva: Aspectos históricos, conceituais e Metodológicos. Ciência e Saúde Coletiva. 1998; 3: 47-60 
93. Tassara E T de O. Ambientalismo e participação na contemporaneidade: reflexões sobre o Ciclo de Seminários. In: Ambientalismo e Participação na Contemporaneidade. Coordenação Marcos Sorrentino. EDUC/FAPESP: São Paulo; 2001. p.210-216.

94. Thiollent M. Reflexões sobre as Perspectivas da Extensão Universitária. I Seminários de Extensão das Universidades Estaduais. Textos de Apoio. Salvador, 1996.

95. Trajber R, Manzochi R. Avaliando Materiais impressos de Educação Ambiental: O Projeto. In: Avaliando a Educação ambiental no Brasil: materiais impressos. Coordenação Rachel Trajber e Lucia Helena Manzochi. São Paulo: Gais:1996.p 138-152.

96. Triviños A N S. Introdução à pesquisa em ciências sociais: a pesquisa qualitativa em educação. São Paulo:Atlas, 1987.

97. UEFS. Relatório 1; Relatório para Processo de Recredenciamento da UEFS.UEFS: identificação e estrutura legal 1996/2000. Universidade Estadual de Feira de Santana/Gabinete da Reitoria, 2001. Feira de Santana.

98. Velasco S L. Perfil da Lei de Política Nacional de Educação Ambiental. 2000. [Documento on line]. Disponível em http://www.sf.dfis.furg.br/mea/remea/vol2art3.html [2002abr17].

99. Vieira P F. Meio Ambiente, desenvolvimento e planejamento. In: Meio Ambiente, Desenvolvimento e Cidadnia: desafios para as Ciências Sociais. Cortez: São Paulo; 1995. p. 45-98.

100. Viezzer M, Rodrigues C L, Moreira T. Relações de Gênero na Educação Ambiental. In: Avaliando a Educação ambiental no Brasil: materiais impressos. Coordenação Rachel Trajber e Lucia Helena Manzochi. São Paulo: Gais:1996.p.15-35

100.Viola E. O movimento ambientalista no Brasil (1971-1991): da denúncia e conscientização pública para a institucionalização e o desenvolvimento sustentável, In: Goldenberg, M., coord. Ecologia, ciência e política. Rio de Janeiro: Revan., 1992 p.49-75

101. Yunes E. Para entender a proposta do PROLER. In Cadernos de Leitura. PROLER, vol. 1 Rio de Janeiro 1994. 
102.WWI. Worldwach Institute. Estado do Mundo 2002. [Documento on line].

Disponível em http://www.wwiuma.org.br. \{2002out 14].

\section{Bibliografia Complementar}

1. Acot P A. Natureza da Humanidade. Ciência e Ambiente 1992; 5:7-17.

2. Farr R M. Representações Sociais: a teoria e sua história. In: Guareschi P, Jovchelovitch S. Textos em Representações Sociais. Petrópolis: Vozes; 1998. p.31-59.

3. Freire P. Extensão ou Comunicação? S. Paulo: Paz e Terra; 10. ed;1992.

4. FUNDAÇÃO BRASILEIRA PARA CONSERVAÇÃO DA NATUREZA. Conceito de conservação. Trad. J.L.Belart. Belém: SUDAM; 1976.

5. Giulliani G.M. Sociologia e Ecologia: Um Diálogo Reconstruído. In: Raízes. 1998;16:25-40.

6. Kesserllring T. O Conceito da Natureza na História do Pensamento Ocidental. Ciência e Ambiente. 1992;5:19-39.

7. Viola, E. Reflexões sobre as dimensões da globalização, as novas forças sociopolíticas transacionais e a redefinição do horizonte da democracia. In: A miragem da Pós-Modernidade: democracia e políticas sociais no contexto da globalização, Rio de Janeiro: Fiocruz; 1997. p.65-77.

8. Viezzer M.L, Ovalles O.(org). Manual Latino-Americano de Educação Ambiental. São Paulo: Gaia; 1994. 


\title{
ANEXO 1
}

\section{Programa de Educação Ambiental desenvolvido na Universidade Estadual de Feira de Santana - Expressões-chave .}

\author{
1. Expressões-chave obtidas da pergunta: Fale para mim sobre o Projeto de \\ Educação Ambiental desenvolvido na Universidade. $O$ que você sabe sobre ele? \\ Idéia Central: Projeto relacionado ao lixo \\ PROFESSOR \\ Expressões-chave
}

P I - O projeto, se eu lembro, tem dez anos, começou em 1992. É um projeto que procura a participação da comunidade universitária, procurando conscientizar esta comunidade no tratamento do lixo, como remover adequadamente este lixo do campus da Universidade. $\mathrm{O}$ projeto é bem aceito, procura educar os estudantes, eu vejo como um projeto bom. Ele procura, também, aproveitar o lixo da comunidade universitária, tanto na reciclagem de papel, como em adubos com a compostagem que eu sei que é feita.

P 3 - Bom, eu tenho que confessar, inicialmente, que eu não conheço muita coisa sobre esse projeto. Eu me lembro, acho que foi em 1992, eu não tenho muita certeza, 92, 91 que eu comecei a ouvir falar sobre a Equipe de Educação Ambiental da UEFS, criando esta equipe ou formando esse núcleo de Educação Ambiental. Eu cheguei a participar de algum seminário, alguma atividade relativa a isso, eu cheguei a ler alguma coisa a respeito da proposta da equipe, do grupo, mas não tenho conhecimento maior a respeito disso. Sei que uma das coisas básicas, que eu acho que são básicas do projeto, é a coleta seletiva, a questão do lixo. Inicialmente no campus universitário, depois abrindo isso para a comunidade, para outros municípios. Mas o que mais me marcou, é o objetivo do projeto: trabalhar com a coleta seletiva, com a reciclagem de lixo e tentar, através destas duas medidas, resolver, tentar buscar formas de resolver o problema, que é um problema contemporâneo mesmo, o da questão do lixo, do lixo urbano sobretudo. Então, o que eu sei, não sei muita coisa, o que eu sei gira em torno disso, de coleta seletiva, de reciclagem através de uma proposta de educação, através de uma reeducação da pessoas, das crianças, das pessoas de forma geral ligadas, ou não, à instituição, à empresa, o que foi através dessa concepção de educação, de reeducação tentar resolver a questão do lixo e o que fazer com o lixo urbano, já que, cada vez mais, a gente tem mais lixo e a gente precisa ter um destino para este lixo.

P 4 - Quando eu cheguei aqui, já existia todo o trabalho, eu já sabia que existia um trabalho de coleta seletiva, sei do núcleo, do grupo de trabalho, o trabalho que se desenvolve lá, de reciclagem.

P 4 - Eu acho que fica a olhos vistos de todo mundo que existe algum trabalho neste sentido, apesar de não perceber a comunidade tão consciente desse trabalho. Isso, para mim, é muito claro. Quando eu falo a olhos vistos são sobre as lixeiras, os adesivos, esta parte visual para mim é clara.

P 5 - Sobre o projeto de Educação Ambiental, o que eu sei é que alguns anos atrás começou a existir um processo de coleta seletiva aqui na Universidade, de reciclagem de material. Nessa oportunidade, as pessoas foram devidamente orientadas, porque eu me lembro, principalmente, da questão de, não só colocar as cestinhas nos módulos. Não foi só uma questão de colocar determinados tonéis nas cantinas, mas houve todo um processo de divulgação, todo um processo informativo com cartazes. Eu lembro que tinha cartazes, as cestinhas eram todas identificadas e cada tipo de lixo deveria ser colocado nas cestinhas. 
ALUNO

A 1 - Sei da Equipe em que o pessoal trabalha, basicamente, com a reciclagem de lixo.

A 2 - O que a gente sabe sobre o projeto é, simplesmente, relacionado às cestinhas de lixo que a gente vê.

A 3 - O que eu sei, basicamente, sobre o projeto é que ele tem a seleção de lixo, tem a postura seletiva do material utilizado aqui na UEFS, tem as vasilhinhas pintadas de azul, verde, cor abóbora. Só que eu não sei dizer onde se coloca cada lixo, já que é seletivo, só se eu olhar e ler. Só pela cor, não dá para identificar.

A 3 - Eu acho isso legal, porque não é só a questão da organização, mas da questão da reciclagem. Fica mais fácil manter a UEFS limpa.

A 4 - Quando a gente entrou na Universidade, como calouro, procurava conhecer mais a Universidade. Geralmente, tinha pouca aula, então a gente foi lá para baixo, onde tem uns lugares em que reciclam papel, parte da reciclagem de todo o lixo que é jogado aqui na UEFS, nestas cestas. Aí a gente conheceu esta parte da reciclagem, como é que funciona.

A 5 - Bom, o projeto de Educação Ambiental, ele procura separar os resíduos, em metal, vidro e tem uma usina de compostagem, que recicla matéria orgânica. Acho que é mais isto, eu sei bem da compostagem que se realiza, transforma o material orgânico. Se os outros materiais são separados e são utilizados aqui mesmo para outras coisas, não sei. Só sei que são separados, tem uma triagem deste material.

A 6 - Olha, eu sei, eu nunca procurei me informar a fundo assim, sabe! Eles têm o trabalho de coleta seletiva, eles têm o trabalho de reciclagem, só que eu nunca tive muito proximidade assim, de ingressar no grupo, procurar saber realmente quais são os fundamentos deles. Mas em questão da organização da coleta seletiva, eles trabalham muito bem. Quanto ao restante, eu não sei informar muito bem, não. Eu acho que eles trabalham com o controle de epidemias ou coisa parecida, não tenho muitas informações, não.

A 7 - Ao entrarmos na faculdade em 98.2, nós tivemos contato com colegas do curso de biologia e, como tem muito tempo já, eu não me lembro de muita coisa, mas eles colocaram para a gente a importância da coleta seletiva, da importância de separar o lixo que nós iríamos jogar fora aqui na Universidade; inclusive, em todos os módulos há uma preocupação tendo cestas específicas, como a cesta de aterro e outra para papel seco, justamente para facilitar essa questão da coleta seletiva que é muito importante e foi abordado por eles.

A 8 - Já existia aqui o programa de educação, a coleta seletiva, já tinha os coletores, os cartazes e o que eu conheci de imediato foi isso.

A 8 - O que eu conheço, basicamente, é isso, são as oficinas de reciclagem de papel e o projeto de compostagem que é desenvolvido lá.

A 10 - O que eu sei é só dos coletores, que, quando eu entrei fui orientada sobre isto. As latas, a coleta seletiva; que tem a compostagem, foi mais ou menos nesta parte. Eles instruem mais ou menos quando a gente entra aqui para começar o processo da Universidade e depois, quem sabe, até lá fora.

F 1 - Não sei muita coisa. É que é feito o serviço de reciclagem e selecionado os lixos, no caso, selecionando os materiais e se tem feito um bom trabalho. Eu, mesmo, já recebi cadernos, rascunhos e outros objetos assim, reciclados aqui na UEFS mesmo.

F 4 - O que eu sei do projeto de Educação Ambiental é que foi uma coisa maravilhosa que aconteceu aqui na UEFS porque antes, o lixo era assim um absurdo, devido à quantidade de alunos, funcionários, muita gente e cada um com uma educação diferente, cada um com uma maneira. Daí, surgiu este programa de Educação Ambiental. Então, foi reciclado o lixo, não cxiste mais lixo na Universidade. Foi separado o lixo, reciclado e que eu sei é assim... Foi uma coisa maravilhosa e seria ótimo se fosse estendido para Feira e região, através de um órgão ou um departamento que tivesse esta separação e sob a gerência da EEA, sob a administração da EEA. 


E quem conheceu a Universidade antes desse projeto de lixo, Ave Maria! Hoje está uma
maravilha, limpíssima.
F 3 - É um projeto que vem sendo desenvolvido e vem trazendo grandes benefícios, não só para
a Universidade, como, também, para a comunidade. Não só para a comunidade de Feira, como
também da região, da micro região de Feira. Os benefícios são para o meio ambiente, na
preservação do meio ambiente.
F 5 - Eu não sei muita coisa, sei, assim, que se faz reciclagem de papel. Quando eu arrumo os
arquivos, eu separo os papéis e ligo para lá, para pegarem os papéis. Não sei muita coisa sobre o
projeto

\begin{tabular}{|c|}
\hline Idéia Central: É um trabalho interdisciplinar e atua nas três missões da Universidade \\
\hline Expressōes-chave \\
\hline PROFESSOR \\
\hline
\end{tabular}

P 1 - Eu faço visitas com meus alunos e a avaliação que eles fazem é que é um começo, que é bom.

P 2 - Acho que eu sei menos que deveria saber, mas já sei que é um trabalho que existe há muito tempo. É um trabalho que tem para mim hoje, embora demorei a entender que era um trabalho interdisciplinar.

P 2 - Vejo como um dos poucos onde pessoas estão efetivamente trabalhando, muitas vezes me serviu de espelho, de exemplo, me serviu de inspiração para fazer pesquisa. Ela não só se restringe a pesquisa, mas faz extensão e, ao meu ver, de forma bem razoável, bem interessante. P 2 - Vi que vocês também fazem outras coisas. A questão da Educação Ambiental, a gente só conhece a parte da coleta seletiva, certamente porque é mais transparente, mais visível $\mathrm{em}$ todos os espaços da Universidade. Mas, depois a gente vai descobrindo e tem toda aquela parte de Educação Ambiental mesmo, de reaproveitamento que vi o pessoal do CHF trabalhando e tem a parte mais de Engenharia mesmo, que é a parte de aterro, sei que tinha alunos de iniciação científica.

P 2 - Em termos de concepção, eu acho muito interessante pois consegue trabalhar a interdisciplinaridade, multi-funcionalidade e atua nas três missões da Universidade que é o ensino, a pesquisa e a extensão. Eu acho isto muito interessante.

P 2 - Eu acho que faltava um pouco... ensino, talvez, pela interdisciplinaridade não fica tão transparente para o ensino, embora na parte de pesquisa e extensão passe para mim uma imagem muito interessante. Agora, com a pós-graduação, deve ter dado um salto $\mathrm{cm}$ termos de envolvimento nos trabalhos da equipe.

P 4 - O trabalho de educação com relação às escolas, os alunos indo visitar, palestras, o trabalho da população mesmo e trabalhos outros de que eu já tive conhecimento que vocês fazem em outras prefeituras, em outras cidades, levando essa parcela de contribuição no sentido da reciclagem do lixo, uma forma racional de trabalhar com essa questão.

\begin{tabular}{|c|}
\hline Idéia Central: Trabalha também com extensão \\
\hline $\begin{array}{rr}\text { Expressões-Chave } \\
\end{array}$ \\
\hline ALUNOS \\
\hline $\begin{array}{l}\text { A } 1 \text { - Eu leciono cm escola pública e, de vez em quando, a gente traz alunos da escola para } \\
\text { obter informações e faz algumas oficinas lá no EEA. Então, eu tenho, por estar há mais tempo, } \\
\text { eu tenho um conhecimento relativo. } \\
\text { A } 2 \text { - Agora tem outdoor lá na frente, falando da coleta de lixo, mas tirando isto, eu estive lá } \\
\text { para fazer um trabalho, um artigo sobre resíduos sólidos, eu estive lá na Educação Ambiental }\end{array}$ \\
\hline
\end{tabular}


A 2 - Eu estive lá porque na minha cidade, nós estávamos com problema de disposição de resíduos sólidos e aí procurei a área de Educação Ambiental e procurei pelos professores A 8 - Sei que tem trabalho de extensão, que eles fazem visitas a feiras livres. O que foi comentado na sala para ver a questão da educação desse pessoal que trabalha em feiras livres, da coleta, da destinação dos resíduos e sei que se pretende desenvolver projetos de esgotamento sanitário e outros projetos.

A 9 - Eu, quando ensinei, na Feira e Cultura com meus alunos da 5 série, o tema foi este, coleta seletiva. A gente fez um trabalho de mostrar a reciclagem, mostramos o adubo que a gente conseguiu aqui da UEFS e fizemos reciclagem de papel, fizemos uma oficina e esclarecemos; fizemos lixeira.

\begin{tabular}{|c|}
\hline Idéia Central: No início tinha divulgação. \\
Expressões-chave \\
\hline PROFESSOR \\
\hline
\end{tabular}

P 2 - O problema todo, que acaba por a gente não saber mais, é a questão de isolamento, a localização no espaço da Universidade, do espaço geográfico na Universidade. Acaba não fazendo, não tornando mais transparente todas as ações da equipe.

P 2 - A coleta seletiva, no primeiro momento, me causou uma certa impressão. Depois de um tempo, parece que deu uma parada no entusiasmo e, nesse entusiasmo, houve mobilização. Depois arrefeceu este ânimo. Acho que ficou mais rotineira, o pessoal olhava achava bonitinho, aquele negócio coloridinho, mas não sentia um funcionamento bom na Universidade. De uns tempos para cá, acho que houve um momento $\mathrm{cm}$ que voltou a ficar mais forte. Acho que melhorou, mas ainda falta, eu sei que é um trabalho difícil; um trabalho de conscientização é árduo, trabalho de mudança de cultura, mudança de hábito.

P 2 - Mas deveria ser um trabalho que fosse mais transparente para que, efetivamente, envolva a comunidade. Tem um grande problema, essa comunidade é cíclica, você tem sempre gente nova para sensibilizar e aí acaba revertendo o quadro e, por outro lado, se não consegue sensibilizar muito bem, pode ser que recaia e tem que voltar e fica esta coisa muito difícil. Tem momentos em que o pessoal participa mais, tem momentos em que o pessoal participa menos e acho que depende muito das ações efetivamente.

P 5 - Mas posteriormente houve uma desativação ou uma despreocupação, não sei, um desgaste, todo um processo de desgaste com relação a isso e não houve uma conservação desse processo informativo.

P 5 - Semestralmente, então saindo e entrando pessoas aqui que precisariam ser devidamente orientadas, devidamente esclarecidas para poder fazer com que esse processo de coleta seletiva pudesse funcionar. Eu suponho que hoje não esteja acontecendo isso. Eu suponho, pelo que eu vejo das cestinhas e da falta de informação e pelo próprio falar, que as pessoas não falam mais nisso é como se passasse despercebida a existência desse processo seletivo.

P 5 - Bom, o que acontece posteriormente a essa coleta seletiva, eu acho que vi alguma coisa no restaurante, sobre como o material é reciclado lá embaixo, foi a única informação que eu tive. $\mathrm{E}$ eu soube também há pouco tempo que no EEA eles reciclam papel e vendem envelopes reciclados. Eu estive, inclusive, há pouco tempo lá no EEA e achei interessante a proposta.

P 5 - Ma há pouca divulgação com relação ao trabalho desenvolvido lá. Primeiro, pela localização, ela é praticamente desmembrada dos módulos, então ir até lá é uma prática que eu acho que poucas pessoas têm. Na realidade, eu estive lá por acaso. Eu achei interessante a proposta desenvolvida pelo EEA. Mas, se eu não tivesse sido convidado para ir lá, se eu não tivesse essa oportunidade eu não saberia como a coisa se passa lá, eu acredito que a maior parte das pessoas que fazem parte da Universidade, que convivem em nosso ambiente universitário, não tem conhecimento disso. 


\begin{tabular}{l} 
ALUNO \\
\hline A1 - Eu acho um projeto muito legal. Logo no início eu acompanhei este projeto, eu acho que \\
tinha mais informação, ele aparecia mais. Hoje em dia, os calouros, eu voltei a ser caloura, eu \\
não tive informação sobre ele; as pessoas não sabem exatamente onde jogar, o que significam as \\
cores. Apesar de estar escrito ali grandão, as pessoas fazem muita confusão. Chega e não fica \\
sabendo o que é isto, para onde vai, o que se faz com o lixo. Antes, eu acompanhei boa parte do \\
projeto, a compostagem \\
A 2 - Nós sabemos que tem. Quando eu entrei logo na Universidade houve maior divulgação. As \\
pessoas saiam de sala em sala de aula, distribuíam adesivos, mas, depois disto, não vejo mais \\
divulgação \\
A 2 - Eu não sei como é que está, mas dentro da Universidade mesmo, em termos de informação, \\
eu acho meio deficitário. \\
A 2 - Eu acho ele muito desvinculado da Universidade, como se fosse um órgão a parte, não sei \\
se é a questão de distância, mas as pessoas não têm o costume de freqüentar a área ambiental. \\
A 4 - Por acaso, conheci também esse projeto. Foi a forma que conheci além das cestas, que tem \\
escrito ali, o que deve ser colocado, mas não que alguém explicasse que existe o projeto, como é \\
feito, não \\
A 8 - Fiz visita ao prédio dessa equipe de Educação Ambiental. Nós visitamos as oficinas de \\
reciclagem de papel. De lá para cá, eu não vi tanta divulgação em termos de coleta, acho que \\
continuou a mesma coisa, no mesmo ritmo. As pessoas que iam entrando, é o que eu suponho, \\
recebiam esse tipo de esclarecimento junto ao treinamento da biblioteca; existia esse projeto e \\
essa divulgação
\end{tabular}

\begin{tabular}{|c|}
\hline Idéia central: Ele dá visibilidade a UEFS \\
\hline Expressões-chave \\
\hline FUNCIONÁRIO \\
\hline F 2 Esse projón
\end{tabular}

F 2 - Esse projeto, desde o início que eu já ouvia falar. Mesmo não tendo nenhuma participação e nem gerenciado nenhuma área que tivesse afinidade, ou que tivesse alguma relação com a equipe. Foi um projeto bastante divulgado e a gente começou a ouvir falar dele. Quando eu assumi esta função administrativa, a relação com a Equipe de Educação Ambiental aprofundou-se por conta da própria necessidade na coleta seletiva e, a partir daí eu comecei a conhecer mais o projeto. A gente ouve falar do projeto na Universidade e fora da Universidade A Universidade, inclusive tem assim um destaque nesse trabalho. Faz com que a Universidade seja conhecida também. A gente ouve em todos os lugares referência ao trabalho da Equipe de Educação Ambiental, em todos os sentidos, a gente ouve falar dele. 


\section{Expressões-chave obtidas da pergunta: Na sua opinião, o projeto mudou alguma coisa na UEFS? Fale sobre isto.}

\begin{tabular}{|c|}
\hline Idéia central: Mudou \\
\hline PROFESSOR \\
\hline Expressões-chave \\
\hline $\begin{array}{l}\text { P } 1 \text { - Mudou, quando a gente vê os coletores de lixo já chama a atenção. A gente procura jogar } \\
\text { no local certo, não deixando contaminar o ambiente. Automaticamente, a gente se lembra que } \\
\text { existem lixeiras em cada módulo. } \\
\text { P } 1 \text { - A gente mudou o comportamento em relação a dar um destino final ao lixo } \\
\text { P } 1 \text { - Mudou o comportamento de alguns, precisa mudar mais ainda. } \\
\text { P } 1 \text { - A gente vê uma conscientização melhor dos alunos. } \\
\text { P } 2 \text { - Eu acho que sim. A gente não fica sempre satisfeito com as coisas e acha que deveria } \\
\text { mudar mais, mas eu acho que sim, as pessoas têm outra postura na ocupação deste espaço } \\
\text { público e a relação das pessoas com o espaço público, que é a Universidade, é diferente da } \\
\text { relação das pessoas em outro espaço público, na cidade, como em Feira de Santana e mesmo } \\
\text { em outros lugares. } \\
\text { P } 2 \text { - Eu acho que se não tivesse o trabalho, as pessoas não se comportariam bem no sentido de } \\
\text { ter esta preocupação, pois mesmo com esta dificuldade de utilizar e participarem da coleta, para } \\
\text { mim está muito claro que, se não houvesse o programa, se fosse uma coisa normal, como já vi } \\
\text { em outras Universidades, as pessoas, pelo menos, olham, têm uma certa preocupação de não } \\
\text { descartar o lixo de forma aleatória, de qualquer jeito. } \\
\text { P } 2 \text { - Acho que o trabalho tem levado as pessoas a se acostumar com o colorido das lixeiras e } \\
\text { acho que seria uma coisa muito estranha se não houvesse. } \\
\text { P } 2 \text { - As pessoas têm procurado colocar nas cestinhas. Eu, pelo menos, tenho olhado e vejo que } \\
\text { está bom, não sei se é impressão minha. } \\
\text { P } 4 \text { - Embora eu não conhecia antes, com relação aos meus alunos, em todas as turmas que eu } \\
\text { tive, pelo menos um aluno se interessava pelo trabalho do ambiente e estava envolvido com o } \\
\text { núcleo de vocês; eles estão antenados com esse trabalho }\end{array}$ \\
\hline $\begin{array}{c} \\
\text { ALUNO } \\
\end{array}$ \\
\hline $\begin{array}{l}\text { A 1- Antes do projeto, ele era espalhado, era queimado e, inclusive, o esgoto também na parte } \\
\text { do fundo aparecia, e o lixo ficava aí muito espalhado. Depois, com o projeto, houve um } \\
\text { trabalho com os funcionários e, mesmo nos próprios departamentos, há uma seleção. A gente } \\
\text { está vendo, tem um resultado. } \\
\text { A } 2 \text { - Com certeza, esta questão mesmo de organização e de limpeza. } \\
\text { A } 6 \text { - Eu acho que mudou alguma coisa sim. Desde que eu entrei aqui, foi o ano que começou a } \\
\text { implantar esse projeto, ou já tinha implantado eu não sei, mas estava no começo. Nessa questão } \\
\text { do lixo, achavam muito incômodo que a gente usava muito balde de lixo. Era lanche misturado } \\
\text { com vasos plásticos, ficava um horror o lixo, sem contar com tanta mosca, principalmente nas } \\
\text { cantinas, próximo às cantinas. Eles selecionaram tampões, vasos com tampôes para lixo } \\
\text { orgânico e esses vasos mais abertos, que são diferenciados por cores, para colocar vidros, papel } \\
\text { seco e copos descartáveis. Mudou bastante a questão da higiene. }\end{array}$ \\
\hline
\end{tabular}


A 2 - Eu acho que tem de positivo é que ele acaba alertando as pessoas. No processo de coleta seletiva, primeiro, podemos observar que ele alerta as pessoas por um lado, mas, por outro lado, não há o envolvimento das pessoas com o projeto. Então, mesmo tendo as cestas e mesmo todo mundo sabendo o que colocar em cada cesta, eu, pelo menos, procuro fazer isto sempre que eu posso. Mas a gente observa, de maneira geral e, até pelo fato de vocês terem colocado aquele outdoor, é que as pessoas não colaboram muito com o próprio projeto.

A 5 - Acho que sim, não para todo mundo, mas algumas pessoas criaram uma consciência maior. Hoje em dia, a gente vê, antes de jogar o lixo, é aqui mesmo? Eu acho que para algumas pessoas provocou alguma mudança, já que é válido.

A 7 - Principalmente na conscientização, tanto do corpo discente como do corpo docente e também dos demais funcionários dentro da instituição. A gente vê que o comportamento da maioria é de auxiliar, de prestar realmente solidariedade à natureza aqui e isso vem acontecendo

F 1 - Eu acho que mudou porque só acrescenta no trabalhos, no desenvolvimento e do jeito que o governo está incentivando a reciclagem e tudo, eu acho que a Universidade tem que ter.

F 1 - Antes não tinha essa organização toda no caso dos lixos, assim dos materiais que hoje são reciclados e no caso aqueles que não eram.

F 2 - Mudou. Pelo menos no problema do lixo que vem sendo feita a seleção de lixo e que isso melhorou bastante o ambiente da Universidade.

F 2 - A gente vê que os papéis começaram a ser reciclados e aí vem trazendo benefício para a Universidade porque os papéis são reaproveitáveis e aí se faz outras coisa com esse papel, como papel machê e papel para a escolinha e creche.

F 2 - Eu acho que tem sido válido este projeto.

F 3 - mas a parte do projeto a gente percebe claramente, a gente observa claramente o comportamento das pessoas que estão no dia a dia da Universidade em relação à limpeza, à coleta de lixo.

F 3 - A gente percebe a diferença quando recebe um público novo, pessoas que participam de atividade durante um dia de outras comunidades e até mesmo da comunidade feirense mas que, naquela dia, a limpeza da Universidade é diferente. As pessoas não têm aquele mesmo comportamento de deixar o lixo no lugar certo e é claramente perceptível quando tem um número de pessoas grande que não é da comunidade

F 3 - Isso eu tenho certeza. Quando eu estudava aqui, não tinha o projeto e se falava no meio ambiente como um todo, mas não tinha nenhum trabalho específico sobre o meio ambiente na Universidade

F 4 - As pessoas ficam mais conscientes na separação de lixo.

F 4 - Mudou porque... existe não sei nem dizer... a parte de aproveitamento de lixo que vocês preparam para a reciclagem e volta para dentro da UEFS, para a gente ter o material reciclado. F 4 - Ainda está pouco, deve amadurecer muita gente aqui dentro.

F 4 - Eu acho que tem economia de papel. As pessoas, antes, jogavam tudo fora e agora tem aproveitamento, não tem tanto desperdício.

F 5 - porque era muita suja a Universidade, não lembro assim a data, há 8 anos quem conheceu a Universidade não reconhece. Quem veio aqui há oito anos, e veio agora não reconhece devido à limpeza da Universidade. E também a reforma que ela sofreu. Mas a limpeza, você não vê lixo, até folha do jardim; eles pegam as folhas para fazer o adubo orgânico, que eu tenho conhecimento. 


\begin{tabular}{|l|}
\hline Idéia central: Mudou só no início \\
\hline \multicolumn{1}{|c|}{ PROFEressões-chave } \\
\hline P 5 - Olha, para mim ele mudou quando foi implantado, no caso da coleta seletiva de lixo. \\
Porque realmente as pessoas tinham uma preocupação em onde colocar o lixo. Hoje, pelo \\
processo de desgaste mesmo, pela não preocupação em manter ativo esse processo, eu acredito \\
que essas mudanças elas sejam incipientes, \\
P 5 - Eu mesmo sabia que existia uma cestinha de uma cor e uma cestinha de outra cor, e numa \\
cestinha de uma cor colocava isso, isso e isso, na de outra cor aquilo e aquilo outro, mas já tem \\
tanto tempo que eu li essas informações que eu não memorizei todas, e aí, na dúvida, vai na \\
que está mais próximo. \\
P 5 - Inclusive a gente tem um resto de papel, a gente já entrou em contato com o pessoal lá de \\
baixo, o papel que poderia e deveria ser reciclado;a gente já entrou em contato varias vezes \\
para virem buscar esse papel a ser reciclado e até hoje o papel está aí. \\
P 5 - então, hoje, eu não acredito que tenha realmente uma mudança, que a gente possa \\
perceber, detectar essa mudança
\end{tabular}

Idéia central: Eu não acredito que tenha mudado tanto ALUNOS

Expressões-chave

A 8 - Mudou as instalações do local, mas o projeto eu não acompanhei essa mudança, essa evolução. Eu não acredito que tenha mudado tanto, eu acho que continua, não sei se está num patamar satisfatório já naquela época, e aí se acomodou. Eu não sei, se fazem também acompanhamento dessa entrada e saída de estudante, dessa demanda do campus. Eu vejo, ainda, um pouco desorganizado as cantinas, a destinação dos papéis, não sei se conseguem separar suficientemente para fazer o trabalho.

A 9 - Eu acho que sim, em parte. A sede é muito afastada da realidade dos alunos. Eu acho que a maioria das pessoas lá fora pensam que a EEA só tem coleta seletiva, que a única coisa que faz é só separar o lixo e muito estudante não sabe que separa, e o que acontece com o lixo aqui dentro. É uma coisa assim: na UEFS tem coleta Seletiva, mas para quê? Ninguém é instruído para quê, o que vai fazer, benefícios, nada disto.

A 4 - Não sei, não sei até que ponto é feito essa reciclagem realmente. Não sei se, por exemplo, ali tem três cestas separadas para você fazer três tipos de coleta. Geralmente, a gente usa só uma, então fica uma coisa, não sei se lá eles separam o lixo, pelo que eu vi eles separavam lá, mas aqui, a gente vê que todos jogam na mesma cesta. Então, a coisa aqui na prática, aqui nesta parte dos estudantes jogarem o lixo na cesta, não é realizada, mas lá em baixo eles podem até fazer a separação.

\section{Idéia Central: Não mudou}

\section{Expressões-Chave}

\section{ALUNO}

A 4 - Quando eu entrei na Universidade eu achei interessante, quando conheci achei interessante. Achei interessante também o fato da Universidade, logo antes de vir a conhecer, ser arborizada, trabalhar essa questão. Eles colocam animais silvestres, tem miquinhos, várias árvores, andam soltos, tem criatório de serpentes, tem biotério, tem vários animais, achei interessante. Para mim, pessoalmente, meio distante, só se tiver mais próximo de cursos como biologia, outros cursos que eles podem trabalhar, ou não, mais essa questão. Mas, para mim, meio distante. 
A 2 - De maneira geral, ele não influencia muito a vida da gente lá fora. É como se o projeto fosse da Universidade e não da comunidade, da sociedade. Essa percepção não vem só do projeto de Educação Ambiental como dos projetos gerais da Universidade. Então, é uma característica geral da academia, da Universidade em relação à sociedade, não há integração

\section{Expressões-chave obtidas da pergunta: Houve mudança pessoal em relação ao projeto?}

\section{Idéia Central: Mudou}

\section{Expressões-Chave}

\section{PROFESSOR}

P 1 - Eu acredito que sim, pois quando eu passo isto para os meus alunos, significa que eu já mudei, em termos de achar que é um projeto bom É um projeto que a gente tem que criar uma consciência nova, como a gente vai remover este lixo porque antes a gente não pensava nisto.

P 1 - Para mim, mudou como uma referência, a gente está dando aula, convida alguém do EEA, esta pessoa vem e já traz informações prática, não fica só na teoria. Eles realizam realmente esta prática de remoção adequado do lixo e mudou o comportamento completamente. Na prática, mudou. Acho que mudou para melhor, porque a gente tem uma referência de um trabalho desenvolvido dentro da Universidade.

P 2 - Já existe muito a questão do hábito, mas o fato de você ver aquilo ali já me induz, em outros lugares, a fazer. De certa forma, a gente fica ligado, pelo fato de ver as lixeirinhas aqui. Eu vou a qualquer lugar e não consigo mais jogar o lixo no chão, eu não consigo mesmo. Se tenho um lixo, ponho dentro do bolso da calça e depois descarto, embora não tenha coleta seletiva, eu chego em algum lugar e descarto. De certa forma, fui influenciado, se não, estaríamos num patamar mais atrasado de jogar o lixo no chão

P 2 - A mudança de hábito, que é um problema cultural, leva um bom tempo e eu já fiquei desesperado porque não achava uma lixeira.

P 2 - Em relação a outras questões ambientais, de certa forma, me despertou interesse em saber - que as pessoas fazem, discutir o que fazem e acabei fazendo um trabalho na área, me aproximei um pouco da discussão de resíduos sólidos urbanos. Eu acho que é fundamental, não é a área que eu quero pesquisar mas acho fundamental que tenha gente pesquisando.

P 3 - Se a gente pensar de uma forma assim, pensando assim, há dez anos atrás, em 92, na Universidade de Feira as condições que ela tinha naquele momento e tal, no interior da Bahia etc. E você pensar que tem um grupo de pessoas que são preocupadas com a questão do lixo, então eu acho que isso, em mim, despertou assim, uma satisfação de saber que tem pessoas que estão preocupadas com isso, que estão trazendo propostas para a solução do problema e buscando solução para o problema. E, acho que mais o que me tocou foi isso, saber que existe isso.

P 4 - Uma das coisas que ele provocou assim, em relação a mim, qualquer trabalho que eu faça, exposição de painel que eu precise eu só trabalho com material reciclado de lá. O papel, eu uso de lá, a gente tem sempre aqui, a gente vai comprar lá e traz, a gente está sempre trazendo isso no sentido de estar sempre indicando, indicando para o trabalho lá. 


\section{ALUNO}

A 1 - A gente que está na área mais voltada para o meio ambiente acha muito interessante, pois eu já utilizei, nas minhas turmas, sempre estou tentando fazer isto.

A 1 - Esta consciência também me ajudou na separação do lixo, mas eu sinto falta que isto se espalhe para a cidade. Por exemplo, eu separo lata ou papel em casa mas não tem para onde levar. Algum papel eu faço, doação, eu já fiz doação para a equipe. Mas a gente não tem para onde levar isto, então deveria expandir mais.

A 3 - Como eu falei, no inicio, foi na questão da limpeza mesmo, porque eu não sei chegar na rua e jogar papel no chão, eu sempre procuro um local para jogar o papel, mesmo que não seja no local adequado, porque aqui é separado por cores, mesmo que não seja assim, eu sempre procuro

A 5 - Mudou, claro! A gente até tenta fazer em outros locais. Onde eu trabalho, na escola, a gente tentou, sabe que é difícil em escolas de ensino médio é mais difícil, mas já tentei. Até aqui mesmo a gente, antes de jogar o material, procura jogar no lugar certo. É aqui? Não, anda mais um pouquinho e joga.

A 6 - O projeto fez pensar, porque eu acho que essa questão da separação do lixo é muito melhor, é muito legal. Eu acho que é até uma questão de evitar uma certa contaminação, a proliferação de mosca, de mosquito que traz maior prejuízo para a gente, de ratos também. É bem interessante

A 8 - Sem dúvida, eu, quando entrei aqui, eu não conhecia, ou conhecia muito pouco de saneamento. Conhecia as coisas básicas, educação doméstica que a gente tem, que é bom mas não tem uma visão global, mais abrangente do que venha a ser o saneamento, a importância sanitária

A 9 - Acho que sim, em parte, sim. Eu, quando estou na rua me envergonho de jogar o lixo no chão. Com vergonha, fico procurando, só jogo em último caso,

A 9 - Aqui na UEFS eu estou esquecida que lixeira é, não tenho vergonha, leio, olho todas e procuro jogar o lixo no lugar certo. Então, para mim é consciência, eu sei que começou aqui e tenho consciência na rua.

\section{FUNCIONÁRIO}

F 1 - A gente tem assim, na mente, que os lixos devem ser aproveitados, inclusive aqui mesmo, a gente separa papelões, papeis que não servem mais, caixas, essas coisas e até, às vezes, liga para a EEA e manda recolher tudo.

F 1 - Também aqui a gente tem o cuidado, quer dizer, de colocar os lixos nas lixeiras adequadas e, antes, ninguém fazia isso

F 1 - Orienta também as pessoas que, às vezes jogam, copinho plástico misturado com papéis e tudo,

F 1 - Nem todo o mundo tem a mesma concepção para isso. Às vezes, tem comodismo de chegar numa lixeira correta para jogar assim os lixos nos lugares devidos.

F 2 - o lixo, pelo menos na Universidade, melhorou muito. Se melhora o espaço físico, melhora também as pessoas que trabalham aqui

F 4 - Sim, porque a gente jogava uma ponta de cigarro fora, agora não joga mais, um palito de fósforo, você já se retrai, você não faz mais isto devido a que, tu vê tudo limpinho você não vai sujar,

F 4 - então, de qualquer forma, educa as pessoas e você se sente melhor em um ambiente limpo, você se sente ótima. Um ambiente desorganizado, até você fica desorientada

F 5 - Antes, a gente jogava tudo fora e agora não, tem um setor.

F 5 - Em termos ambientais, eu sei que tem que reciclar, não deve jogar fora, que prejudica a natureza 


\begin{tabular}{|c|}
\hline Idéia Central: Eu já tinha preocupação com a questão ambiental. \\
\hline PROFESSOR \\
\hline Expressões-Chave \\
\hline $\begin{array}{l}\text { P } 3 \text { - Olha, em mim eu já tinha esse hábito, eu já tinha essa preocupação com o lixo. Eu acho } \\
\text { que faço isso instintivamente. Tecnicamente, cu não jogo lixo na rua, eu sou daquelas que } \\
\text { guardam o papel na bolsa, o pauzinho de picolé na bolsa e educo minha filha desta forma. } \\
\text { Então em mim, não teve mudança. }\end{array}$ \\
\hline ALUNO \\
\hline $\begin{array}{l}\text { A } 7 \text { - Essa preocupação com a questão ambiental é uma coisa que eu trago comigo há bastante } \\
\text { tempo. E pela disciplina na área ambiental, na nossa grade curricular, a gente já teve a nossa } \\
\text { mentalidade bastante aguçada com essa disciplina. E também, essa preocupação da instituição } \\
\text { com a questão ambiental veio contribuir para a gente realmente ter essa consciência contínua, } \\
\text { não uma coisa que possa se perder com o tempo, mas solidificá-la. }\end{array}$ \\
\hline FUNCIONÄRIO \\
\hline $\begin{array}{l}\text { F } 3 \text { - O projeto só veio fortalecer aquilo que eu penso sobre o meio ambiente, a importância } \\
\text { que tem a gente preservar o meio ambiente. Eu penso que o meio ambiente é muito importante } \\
\text { que a gente tenha que cuidar dele. Então o projeto só veio solidificar essa consciência que eu já } \\
\text { vinha adquirindo na minha experiência ao longo da minha vida. }\end{array}$ \\
\hline
\end{tabular}

\begin{tabular}{|c|}
\hline Idéia Central:Mudou só em determinado período \\
\hline Expressões-Chave \\
\hline PROFESSORES \\
\hline
\end{tabular}

P 5 - Bom, no período sim. Hoje, eu ainda guardo resquícios, porque eu sei que existia a cestinha para cada coisa, mas como eu não lembro qual é a cestinha que vai o quê, ou eu acho que estou colocando na cestinha certa. As cestinhas que sobraram aí, e que algumas foram removidas, desapareceram, poucas ficaram disso daí. Bom, eu, pessoalmente, sinto falta disso, P 5 - Em Montreal, eles têm uma coleta seletiva na cidade, então existe o dia de lixo orgânico e o dia de lixo seco e, então, você convivendo com aquilo, acaba se acostumando. É igual ao cinto de segurança, que a gente não usava, e você é obrigado a usar. Quando você se acostuma com aquilo, com o uso do cinto você faz automaticamente.

P 5 - Existem dificuldades, seriam dificuldades em se desenvolver esses hábitos, das pessoas fazerem sem pensar

P 5 - e para que isso acontecesse, realmente, todo semestre, os alunos que chegam deveriam ser orientados. Antes nos MPs e nos MTs existiam as cestinhas entre os módulos e essas cestinhas elas não existem mais. Existem cestas de lixo só que não são seletivas. Tudo bem, as cestas estão lá, mas não são seletivas.

P 5 - Então, mudou em determinado período, a questão do meu comportamento. Hoje, eu tenho cuidado de não jogar lixo onde não deve ser jogado, mas, em selecionar o lixo. eu não posso mais assegurar que há uma mudança, eu perdi isso ${ }^{\mathrm{PS}}$. 


\section{Expressões-chave obtidas da pergunta: Você participa de alguma forma neste projeto? Fale-me sobre isto.}

\begin{tabular}{|l|}
\hline \multicolumn{1}{|c|}{ PRóia Central: Participo indiretamente } \\
\hline \multicolumn{1}{|c|}{ Expressões-Chave } \\
\hline P 1 - Minha participação é um pouco assim indireta, não participo ativamente, não tenho uma \\
participação prática com a Equipe. \\
P 1 - Minha participação é teórica, de conhecimento teórico, participação indireta. Participo \\
levando os alunos para conhecer, ver o que desenvolvem neste projeto \\
P 1 - Quando tem pesquisas sobre a remoção adequada de resíduos sólidos, os alunos procuram \\
uma referência que é a Equipe de Educação Ambiental. \\
P 2 - A gente, no projeto em si, não. A não ser na participação do descarte. \\
P 2 - minha participação é em ouvir o que as pessoas fazem e saber o que está sendo feito pela \\
equipe. \\
P 2 - A gente tem acompanhado através das notícias que chegam ao departamento \\
P 4 - Não, eu nunca participei diretamente não, nunca. A única coisa que a gente tem é, às \\
vezes, o cuidado de observar, onde é que está botando o lixo e o que é que vai botar no lixo, o \\
que é que a gente pode aproveitar, tentar selecionar de alguma forma aqui dentro da instituição, \\
mas, diretamente, nunca trabalhei não, nunca fiz nenhum trabalho. \\
P 4 - Participo indiretamente via alunos, entendeu? Dando aula quando a gente fala da questão \\
das doenças e de todos os meios que você pode adquirir, vem o lixo, vem uma série de outras \\
coisas. A gente está apontando que tem um trabalho aqui, tem uma reciclagem que é feita aqui, \\
aí é importante que eles visitem
\end{tabular}

\section{ALUNO}

A 1 - A única forma que eu participo hoje é jogando o papel na lixeira azul e o aterro no laranja.

Al - Mas, fora esta interação de usar e pedir informação, eu não me vejo participando mais. Eu sou um dos componentes lá da fase final do projeto. Não me sinto mais integrada a ele, apenas nesta parte

A 2 - Acho que a única participação que a gente tem é o fato de colaborar com a coleta seletiva. Tirando isto não existe nenhuma espécie de participação aqui.

A 3 - Eu acho que a Universidade toda de uma forma indireta, participa por estar todo mundo tendo que fazer isto, colocar o lixo no seu devido local.

A 3 - Em parte, é como obrigação, sim, mas é uma questão de cidadania e para ajudar na limpeza também e tem a ver com cidadania

A 4 - A gente participa porque, de qualquer forma, separa o que a gente consumiu. Joga cada coisa no seu devido lugar, participa passivamente

\section{FUNCIONÁRIO}

F 3 - Participação direta, eu não tenho. O que eu tenho é no meu trabalho do dia a dia, as atribuições do meu cargo fazem com que eu tenha a participação no sentido de dar o apoio, dar infra-estrutura para que ele possa ser desenvolvido, mantendo a rotina da coleta, fazendo com que as pessoas entendam que é muito importante a coleta e que respeitem as orientações da Equipe de Educação Ambiental. Isso eu tenho feito, e acho que contribuo neste sentido. 


\begin{tabular}{|l|}
\hline Idéia Central: Eu participo na separação do lixo e na divulgação do projeto \\
\hline \multicolumn{1}{|c|}{ Expressões-Chave } \\
\hline FUNCIONÁRIO \\
\hline F 1 - Eu participo e acho que todos nós que trabalhamos aqui participam entendeu? Porque, \\
desde quando a gente tem as lixeiras todas padronizadas e tem a preocupação de colocar o lixo \\
na lixeira correta, eu acho que a gente já está participando. \\
F 2 - Eu participo, sim, na seleção do lixo \\
F 2 - A gente procura incentivar, não só os alunos, mas os professores e funcionários para \\
procurar fazer um trabalho sério sobre o processo de seleção do lixo \\
F 4 - Eu participo ao jogar o lixo no lugar certo, a separação do lixo, a gente separa o lixo. \\
F 4 - Eu divulgo que na Universidade, existe um projeto ambiental. Eu falo para as pessoas e \\
do que hoje é a Universidade em termos de limpeza, em consequeência desse projeto. \\
F 5 - Ajudando na separação do material, \\
F 5 - Quando alguém pergunta alguma coisa, eu informo, separo papel. Estas coisas aqui a \\
gente só lida com o papel e copinho. Eu informo as pessoas, quando elas têm muito papel. Daí \\
eu aviso que na Educação Ambiental eles recolhem papel.
\end{tabular}

\begin{tabular}{|c|}
\hline Idéia Central: Não participo \\
\hline \\
\hline Pxpressões-Chave \\
\hline PROFESSOR \\
\hline
\end{tabular}

P 5 - Eu, pessoalmente, procuro, sempre que vejo meu aluno jogando lixo onde não deveria ser jogado ou deixando sujo o local que não estava sujo, eu procuro orientar no sentido de colocar o lixo no lugar certo. Mas, mais que isso, acho que é impossível fazer, justamente pela parte de informação. A parte informativa não está aí para a gente poder, inclusive, chamar a atenção com relação a isso, então eu não teria como participar.

\section{ALUNO}

A 6 - Não tenho ligação nenhuma com o projeto de Educação Ambiental. Só nessa questão de utilizar corretamente o que eles propõe e tudo, mas eu nunca tive muito contato com eles. Mesmo porque, desde que eu entrei aqui, eu trabalhei o dia todo, então o meu limite era o que? As aulas pela manhã e pronto. Saía correndo daqui para o trabalho, nunca voltava, só, às vezes, na biblioteca a noite. Quando chegava, não tinha muito tempo.

A 7 - Eu acho que, talvez, seja até uma falha desse projeto, do curso, da instituição não contar com o apoio permanente assim dos estudantes. A gente tem conhecimento de alguns acontecimentos que vão se apresentando, mas eu acredito que não há uma participação efetiva da grande maioria dos estudantes da UEFS.

A 8 - Não participo, nunca participei. Eu priorizei. Como trabalhava, eu já comentei no início da entrevista, eu trabalhava fora, restava pouco tempo para a faculdade e eu quis dar prioridade ao curso, em detrimento do estágio. Evidentemente, se você puder fazer os dois é ótimo, mas nem sempre isso é possível. Eu não tenho como me manter só estudando, eu tinha que trabalhar. Isso fez com que eu ficasse na faculdade restritamente no horário de aula

A 8 - Às vezes a gente esclarece ao aluno novo como é feito, já indiquei para algumas pessoas fazer a visita, depois que eu fiz. As pessoas que tinham interesse, mostrava onde é que é feito isso, indicando aos alunos novos do curso. Mas o envolvimento efetivo no projeto não tive, eu não vou dizer que tive. Só como produtor de lixo.

A 9 - O único contato que tive, foi quando entrei na Universidade. Fui esclarecida, tive conhecimento da EEA, estive lá porque estou fazendo a disciplina com um professor daqui. Acho tão longe, é difícil.

A 9 - Já vim outras vezes porque fiz a Feira de Cultura com meus alunos. Então, a gente tem que estar instruída, peguei material, aprendi a reciclar com o pessoal, vim, busquei e levei material para os alunos. De qualquer jeito estudei, me envolvi. 


\section{Expressões-chave obtidas da pergunta: Em que aspecto o projeto poderia ser melhorado? Fale-me sobre isto"}

\begin{tabular}{|c|}
\hline Icléia Central: $O$ projeto precisa ter mais visibilidade e uma maior divulgação \\
\hline PROFESSOR \\
\hline Expressões-Chave \\
\hline
\end{tabular}

P 2 - Depois de tudo que a gente falou, o processo tem que ter paciência, ter metas conscientes, mudança de cultura, mudança de paradigma até não é uma coisa que vai acontecer facilmente. É um processo bem lento, de mudança gradual e qualquer vitória tem que ser comemorada.

P 2 - Agora, o processo tem que ser mais transparente, as ações da EEA tem que ser mais transparentes. Eu acho que são mais transparentes para fora da Universidade do que para dentro da própria Universidade. Participam de Congressos, vem gente de fora buscar informação e, aqui dentro, não é tão valorizado como devería, como é valorizado por outras Universidades, de outros centros e de locais que têm contato com o trabalho da EEA.

P 2 - Acho que o grande pecado da EEA é não saber vender o peixe, acho que tem que pegar alguém de marketing e tornar mais transparente suas ações, para aumentar o envolvimento das pessoas. Quem conhece um pouco, se encanta com o projeto

P 3 - Eu acho que, primeiro, a gente tem que ter mais visibilidade,

P 3 - Alguns anos atrás, eu acho que tinha mais visibilidade e que depois parou de Ter. Não sei porque, mas parou de ter. Então, ficou só a coisa da latinha. A latinha, eu acho que as pessoas não ligam muito, usam como lata de lixo e aí nem lêem o que está ali, nem sabem porque é colorido, nem nada

P 5 - Primeiro, a questão da informação, voltar a informar as pessoas

P 5 - O aluno entra aqui semestralmente. Os alunos entram e saem daqui semestralmente, então, todo semestre, realmente, esse aluno que chega deveria ser informado e devidamente orientado para isso. Eu acho que a EEA poderia, também, encontrar meios de atrair a população universitária para conhecer, inclusive, a estrutura do projeto

P 5 - Participar mais diretamente do que a EEA, oferecer, talvez cursos, oferecer, sei lá, ateliês, oferecer, demonstrar mais, divulgar o próprio material que é produzido na EEA

P 5 - Chamando a atenção dessa comunidade, dessa população para poder visitar o que é o processo. Isso faz parte também da comunicação, de uma boa campanha de divulgação, uma boa campanha de promoção. Uma boa campanha de sedução das pessoas que compõem a Universidade

P 5 - Como eu estava falando, que o aluno não conhece; o aluno, o professor, o funcionário não conhece a EEA, o próprio prédio da EEA. Pensei também no pessoal da noite. $O$ pessoal do diurno já não tem acesso, ou não tem a iniciativa de chegar lá para ver o que é e como funciona. Imagine o pessoal do noturno, porque o prédio fica num local que não é estratégico 


\section{ALUNO}

A 1 - Eu acho que ele deve retornar a fazer maior divulgação, fazer trabalhos na própria comunidade universitária. Eu estou sentindo falta dele.

A 1 - É divulgação, eu não sei por exemplo como está a compostagem, como está utilizando isto e, nem mesmo, os produtos que o pessoal tem feito, não tenho visto,

A 1 - então, eu acho que está precisando mostrar o que se está fazendo para a gente, integrar mais as pessoas para que elas se sintam mais atuantes como se fosse parte do projeto também.

A 1 - Eu acho que, quando a gente se sente parte de qualquer idéia, você pode trabalhar melhor, pode ajudar. Caso contrário, talvez ele nem funcione, porque a coisa se torna assim consciente A 2 - Eu acho que a primeira coisa que ele deveria fazer, é tentar envolver membros da própria academia, integrar, de alguma forma, não sei se em forma de bolsa ou de desenvolvimento de projeto

A 3 - Eu acho que a divulgação é pouca, que eles estão muito... a equipe mesmo responsável está preocupados melhorar mais, em crescer. Mas não há muita divulgação, deveria ter mais palestras, informar mais aos estudantes, porque é importante para que a gente conheça mais a realidade. Eu fiquei sabendo do projeto através de panfletos e por causa das vasilhas de lixo.

A 4 - Eu acharia interessante a gente saber até o fim do projeto. Para onde vão todos esses resíduos, o que é que é feito.

A 6 - Eu acho que eles poderiam abranger mais essa questão de toda a Universidade, em abrir palestras, deixar a Universidade mais informada sobre o que é esse projeto de Educação Ambiental,

A 6 - Não se tem informação de palestras que sejam promovidas, abertas para a comunidade, que eles promovessem junto com os DAs

A 6 - Eu acho que Educação Ambiental também deveria ser aberta de uma forma que todos participassem e pudessem se inteirar mais dessa questão do que é Educação Ambiental, e que proposta eles têm aqui dentro da Universidade.

A 7 - O que poderia ser melhorado - eu acho que essa questão da participação, sem dúvida, é algo que deveria ser melhor pensado. Quando eu falei na participação, é no sentido de uma interação maior entre as pessoas que estão na organização, no gerenciamento desse programa com a comunidade. Como, por exemplo, com a apresentação de seminários.

A 8 - A educação, eu acho, que tem que ser contínua. Eu não vejo uma continuidade, um esclarecimento. Os novos alunos que entram na faculdade não sei se estão recebendo essa orientação. Existe a TVU que deveria estar constantemente falando isso aí e tentando A 9 - Para mim, deveria envolver os alunos e a comunidade $\mathrm{em}$ geral. Geralmente quem é mais ligado são os alunos que fazem biologia, os alunos que têm mais contato com a área, biologia

\section{FUNCIONÁRIO}

F 3 - Em relação à programação visual para divulgar a coleta seletiva, eu acho que não foi muito bem assimilada; eu não sei se é por conta dessa programação que não é eficiente ou se falta alguma coisa

F 4 - o que eu acho que deveria ter é uma divulgação maior do que a EEA produz. Sobre o adubo orgânico, ter uma divulgação e uma comercialização desses produtos

F 5 - sei lá, mais divulgação. Nos setores tem muita gente nova. 


\begin{tabular}{|l|}
\hline Idéia Central: Tem que se mais educativo \\
\hline \multicolumn{1}{|c|}{ Expressões-Chave } \\
\hline PROFESSOR \\
\hline P 3 - Tem que ser mais educativo ainda. Eu acho que está sendo pouco educativo. \\
P 3 - Ele tem que provocar nas pessoas um certo, um certo constrangimento com o \\
comportamento que cada um tem em a relação ao seu próprio lixo, ao lixo que ele próprio \\
produz, que provoque mais as pessoas a se tocarem, mesmo e, a partir daí, ir mudar o \\
comportamento. Ou ter a curiosidade de saber porque que tem que reciclar, porque que tem que \\
ter coleta seletiva, porque que tem que ter um depósito de lixo e tal e de tal jeito ou uma usina \\
de beneficiamento de lixo. Porque isso é que é importante, está relacionado a questão do meio \\
ambiente. \\
P 3 - Eu acho que hoje, século XXI, como dizem, o meio ambiente é a nossa grande discussão \\
daqui para a frente. \\
P 3 - A gente está vendo cada vez mais a degradação das cidades, e isso está começando a \\
atingir profundamente as pessoas, com as epidemias, endemias, doenças e mais doenças aí \\
voltando, matando, dizimando e tal. Então, eu acho que precisa ter alguma coisa dentro do \\
projeto que faça isso aparecer mais. \\
P 3 - Eu acho que tem que ter algumas coisas mais, mais duras, mais incisivas, mais educativas. \\
Talvez, não sei, algumas coisas que envolvam mais a comunidade universitária, alguma coisa \\
mais leve, mais lúdica através de teatro, dança, de alguma performance. \\
P 3 - Se sinta parte integrante daquilo ali e acabe se envolvendo e gostando e aquilo fique \\
registrado na memória dele. E ele vai passando adiante, eu acho que é alguma coisa por aí. \\
P 4 - De uma conscientização maior nossa dentro da Universidade. Uma coisa assim maior, de \\
se tornar bem mais ostensiva, porque existe. Mas é como eu digo a você, eu não sinto assim, \\
está aí, todo mundo está vendo, está vendo que tem de separar, está vendo que tem que reciclar, \\
você está vendo pessoas jogando a coisa do outro lado, até fora da lixeira está acontecendo. \\
\hline
\end{tabular}

\begin{tabular}{|c|}
\hline Idéia Central: O projeto deve extrapolar os muros da Universidade \\
\hline PROFESSOR \\
\hline Expressões-Chave \\
\hline P
\end{tabular}

P I - Eu acho que deveria extrapolar o campus. Eu acho que já tem, mas não conheço o projeto fora do campus da Universidade. Pelo menos, conscientizar o pessoal de bairro. Aqui, o pessoal é privilegiado, que faz a Universidade, tem conhecimento. Poderia estender mais para a população feirense para melhorar este destino de lixo a céu aberto que a gente vê muito. Lixo em feira livre que a gente vê muito, lixo ainda à toa. Então, eu acho que deveria estender mais esta educação, educação permanente com a comunidade, com a população de maneira geral.

P 5 - Também a comunidade fora da Universidade. Porque o projeto que vocês desenvolvem pode e deve, necessariamente, atingir as escolas de ensino médio e ensino fundamental porque nas disciplinas de ciências, nas disciplinas de biologia, eles trabalham com ecologia, trabalham com Educação Ambiental.

P 5 - Toda essa discussão que a gente teve aqui com relação aos cestinhos, a separação do lixo, a reciclagem também, a reciclagem do lixo, pode e deve ser desenvolvida na escola de ensino fundamental, do ensino médio.

P 5 - A EEA poderia atuar de forma mais efetiva, não apenas na Universidade que é importante. É importante o ambiente em que a gente vive, o ambiente em que a gente trabalha, o ambiente em que a gente passa uma boa parte do tempo da vida da gente. Aqui é importante, mas, se toda essa produção de conhecimento, extrapolar os muros da Universidade, ganhar a comunidade, ganha a própria Universidade, ganha todo mundo de um modo geral. Vem aquela coisa toda da gente estar evitando doença, a gente estar fazendo uma série de coisas, trazendo benefícios. 


\section{ALUNO}

A 5 - Na UEFS tem recipiente em todos os lugares e tem ampla divulgação. São vários cartazes, eu acho suficiente. Mas poderia abranger mais, sei que é difícil, mas abranger mais a conscientização das pessoas. Na UEFS não circulam só pessoas do mundo acadêmico, tem pessoas de outro local que não estão ligadas neste projeto, então não se preocupam muito com isto. Pelo menos na comunidade perto que freqüenta mais a UEFS, poderia ter uma divulgação um pouco maior.

A 8 - Acima de tudo, expandir e difundir isso aí pela região de Feira de Santana, extra-campus para não ficar só como projeto piloto que a gente imagina. Porque eu acho que já tem tempo suficiente para sair dessa fase de estudos e fazer isso tudo atingir a sociedade que é o alvo.

\section{FUNCIONÁRIO}

F 2 - Procurar as autoridades para que tivesse um apoio das autoridades municipais, estaduais e até federal para que esse projeto venha melhorar o município de Feira de Santana e a micro região de Feira.

F 4 - Aqui dentro da Universidade, eu acho que não está faltando nada.

F 4 - Divulgar e também ensinar as pessoas nas comunidades, em cidades vizinhas, em bairros, a fazer uma separação e fazer ali um núcleo de reciclagem desse lixo. Porque aí tem o adubo orgânico que venderia, a reciclagem do papel, latas, garrafas, plástico também, e aí pronto. Só falta divulgação e comercialização do lixo.

\begin{tabular}{|l|}
\hline Iléia Central: Treinamento das funcionárias de limpeza \\
\hline \multicolumn{1}{|c|}{ Expressões-Chave } \\
\hline FUNCIONÁRIO \\
\hline F 1 - Que as serventes, no caso, sejam treinadas para que façam a seleção dos lixos quando elas \\
forem fazer a limpeza nas salas. \\
F 1 - Que recolham o lixo separado para não colocar tudo junto. No caso, o setor tem o \\
cuidado de separar os lixos e elas vêm e colocam tudo em um saco só. \\
\hline
\end{tabular}




\section{Expressões-chave obtidas da pergunta: Lixo, você tem alguma coisa a ver com isto? Fale-me sobre isto.}

\begin{tabular}{|c|}
\hline $\begin{array}{l}\text { Iléia Central: Tenho, todo mundo tem a ver com o lixo eu produzo e devo manuseá-lo } \\
\text { adequadamente }\end{array}$ \\
\hline PROFESSOR \\
\hline Expressões-Chave \\
\hline
\end{tabular}

P 1 - O ambiente é o lugar onde a gente convive, então tem que se preocupar como vai ser removido este lixo

P 1 - Se a gente está fazendo uma remoção adequada desses resíduos sólidos, a gente também está melhorando, não só a parte estética, mas melhorando economicamente. Porque a gente está aproveitando o lixo. O que é lixo, para a gente, é matéria prima para alguém. Quando a gente vê os catadores de lixo aproveitando muito material do lixo que pode ser reaproveitado, a gente tem que pensar nisto também. A gente tem que fazer parte também, não é uma coisa longe da gente.

P 3 - Toda, acho que todos nós temos tudo a ver com o lixo. Nós é que produzimos o lixo e, cada vez, a gente produz mais lixo, cada vez mais a gente... A própria indústria de consumo, ela nos obriga a produzir mais lixo, porque tudo é descartável, tudo você joga fora, quase nada é reaproveitável. Quando é reaproveitável tem até escrito lá na garrafinha e tal, é reciclável, mas você acaba jogando aquilo fora.

P 3 - Eu acho que todos nós somos completamente responsáveis para buscar soluções, não produzir tanto lixo, e o que for produzido ser o mínimo, poder reciclar o máximo, poder transformar o máximo, dar uma outra utilidade, reutilizar e aquele minimozinho que não tem jeito mesmo, aí sim seria aquele lixo descartado.

P 4 - Só o que eu produzo, só o que eu produzo, assim tenho a ver.

P 4 - O que está indo para o lixo realmente é para ir para o lixo, e onde a gente vai jogar esse lixo?

P 4 - Então, essa questão de lixo a gente tem que tomar muito cuidado. Lá em casa, principalmente, o que a gente pode reaproveitar, roupa não se joga em lixo, remédio não se joga em lixo. Fora da validade, abre-se e joga-se no esgoto, faz alguma coisa dessa natureza. Então, o lixo tem a ver tudo comigo, não tem jeito.

P 5 - Eu tenho tudo a ver com isso, porque eu produzo lixo também e eu sou vítima do lixo que você produz.

P 5 - Eu acho que a gente poderia ter uma outra consciência. O que é que eu tenho a ver com o lixo? Se, por exemplo, existe lixo orgânico que eu produzo em minha casa, e esse lixo orgânico poderia ser reciclado por mim mesmo dentro de casa que aquele lixo orgânico que eu produzo é adubo.

P 5 - Que mais eu teria a ver com o lixo, agora não me vem. Mas diariamente, nós estamos produzindo e, se nós se tivéssemos uma informação maior, uma consciência maior, muitas vezes uma estrutura maior que você vê, mesmo que no centro da cidade nós não temos uma estrutura que possibilite nós nos desfazermos do lixo. 


\section{ALUNO}

A 1 - Eu sei que produzo quilos de lixo por ano, com certeza, a gente tem quem dar o destino. A 2 - Acho que todos nós temos a ver com o lixo. Acho que o lixo é sempre tratado como se fosse um problema da prefeitura, como se nós não tivéssemos nada a ver. Só que nós vivemos em uma sociedade altamente consumista, então nós estamos produzindo lixo a cada segundo. Em qualquer lugar que a gente esteja estamos produzindo lixo. Então, nós somos produtores de lixo e não nos preocupamos com o destino final dele, só queremos saber se a prefeitura tirou da nossa porta e se colocou adiante. Não interessa onde ele está sendo disposto, ninguém quer saber nada disto. Então o lixo é parte integrante da nossa vida em todos os momentos e a gente não se preocupa muito com isto.

A 2 - Então a gente não tem essa preocupação. É como se fosse algo que estivesse externo à nossa vida, basta fazer a limpeza da nossa porta, não interessa onde o lixo está. Acho que tem este lado aí.

A 4 - Tenho e gostaria de ter mais. Tenho porque é uma coisa que a gente produz. O lixo a gente produz, a gente consome a coisa pronta, industrializada, produzida, limpa e a gente vai produzir uma coisa contaminada através das outras pessoas. Contaminada, ruim, tóxica, tá ali. A gente está jogando no ambiente. Então, eu acho que a gente devia ter mais a ver, porque deverá saber mais sobre isso.

A 5 - Tudo, porque lixo é tudo que a gente gera e acha que não presta. Se as pessoas tomassem um pouquinho mais de consciência que lixo, que a maior parte do lixo pode ser reaproveitada, porque a maioria do lixo que produzimos é matéria orgânica e pode ser usada em inúmeras funções, se todo mundo pensasse assim poderia ser melhorado, problema da fertilidade do solo, eutrofização de lagos. A gente tem, todo mundo tem a ver com isto, tem muita responsabilidade com o lixo que produz.

A 6 - Tenho muita coisa a ver com o lixo, eu acho que o problema todo do lixo somos nós, de uma certa forma direta e indireta nós produzimos o lixo, e somos responsáveis por esse lixo. Existe uma grande preocupação de aonde vai parar esse lixo.

A 6 - Eu acho esse controle do lixo hoje muito importante, então, você deve ter um lugar separado, um local adequado para armazenamento desse lixo, estocagem dele, seleção, eu não sei.

A 8 - Tudo, eu produzo, eu tenho que dar algum destino a ele. Eu sou consumidor e sou cidadão, eu tenho que olhar para a sociedade, para o presente principalmente, e para o futuro. $\mathrm{E}$ se a natureza não tem como decompor ou reciclar esse lixo com a mesma velocidade que a gente produz, nós temos que dar nossa mãozinha de contribuição, temos que acelerar esse processo de reciclagem, ajudar a natureza a fazer e consertar. Porque, afinal de contas, nós é que estamos produzindo e em velocidade altíssima Se a gente não pode evitar esse crescimento populacional como ele acontece, consequentemente, gerando lixo em quantidades cada vez maiores, a gente tem que ter uma intervenção nisso aí, para poder manter esse equilíbrio. Equilíbrio homem-natureza, é isso que a gente tem a ver, eu só não, cada cidadão, cada ser humano.

A 9 - Me pegou. Eu acho que a gente poderia fazer muita coisa para diminuir esta quantidade de lixo. Eu tenho a ver.

A 9 - O que a gente poder reciclar já é de grande importância porque vai diminuir a quantidade no ambiente, então eu acho que a gente pode diminuir, acabar todo jamais. Mas o que a gente puder fazer para diminuir, então temos muito a ver, podemos melhorar bastante. Agora, nem todo mundo tem consciência disto. Muita gente tem até boa vontade, mas o que vai fazer com este lixo todo? Aquela garrafa descartável que pode não ter significado, para outros tem. 


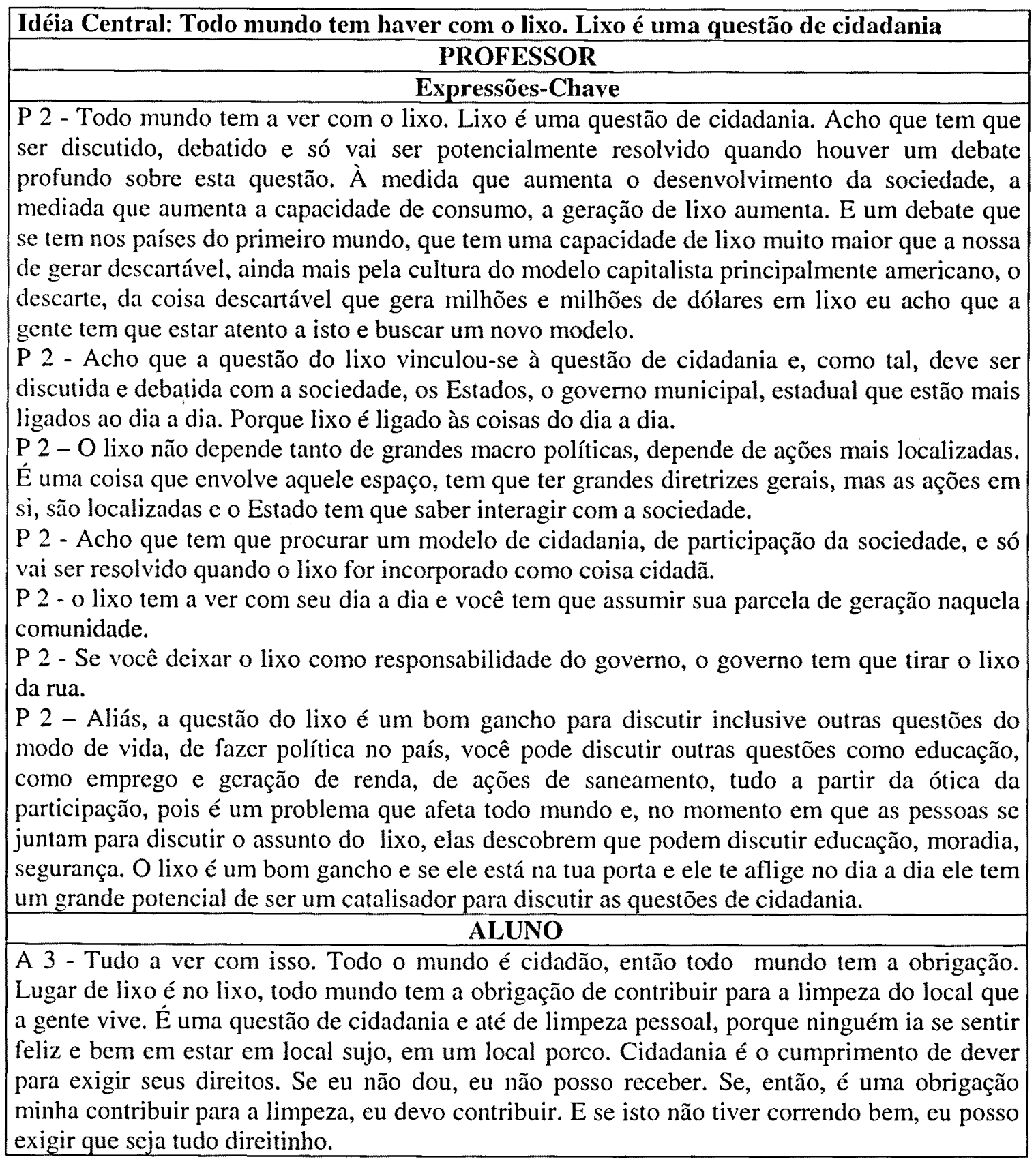




\begin{tabular}{|l|}
\hline \multicolumn{2}{|c|}{ Idéia Central: Lixo como um dos problemas ambientais e de saúde } \\
\hline \multicolumn{1}{|c|}{ ELUNo } \\
\hline \multicolumn{1}{|c|}{ AL } \\
\hline A 6 - Tem uma outra comunidade aqui, esqueci o nome da comunidade em que eles \\
trabalhavam e em que esse lixo era jogado em ruas, em terrenos baldios. Então, estava trazendo \\
leptospirose por causa dos ratos e as crianças estavam contraindo ameba, certas doenças por \\
estarem em contato com esgotos abertos. Eu acho esse controle do lixo hoje muito importante. \\
A 7 - A questão do lixo é uma questão muito discutida hoje, principalmente, em relação à \\
degradação ambiental. Sabemos que a realidade nossa é diferente da de países considerados \\
desenvolvidos, onde a questão da consciência com o lixo é mais forte. Mas sabemos, também, \\
que lá a preocupação com o meio ambiente no seu aspecto geral também não é permanente. A \\
gente sabe que, por exemplo os Estados Unidos, grande potência mundial, se recusaram a \\
aderir ao pacto de Quioto que é uma coisa muito séria. \\
A 7 - Com certeza tenho a ver com o lixo porque faço parte, hoje faço parte daqui da \\
comunidade de Feira de Santana, não permanentemente, mas transitoriamente. Acho que tenho \\
o papel, sim, e tenho que dar a minha contribuição para com este ccossistema, porque a gente \\
entende que ele deve ser preservado, isso é um papel que cabe a todos, não somente a um \\
segmento especial da nossa sociedade. \\
A 1 - Mas, quando você fala em lixo e vê aquelas pessoas que trabalham em aterros sanitários \\
se alimentarem daquilo, a gente fica pensando na responsabilidade que se tem também com \\
estas pessoas e com o próprio ambiente que a gente vive e com o próprio planeta. O que fazer \\
com este lixo, então, quando a gente tem uma alternativa que ele possa melhorar e não causar \\
um dano tão grande ao ambiente. Eu vivo tentando fazer isto.
\end{tabular}

\begin{tabular}{|c|}
\hline Idéia Central:Todos nós temos a ver com o lixo \\
\hline Expressões-Chave \\
\hline FUNCIONÁRIO \\
\hline
\end{tabular}

F 1 - Porque as pessoas têm que se educar, saber selecionar o lixo e também a limpeza A educação faz parte, sim, do dia a dia de nossa vida. Se a gente for uma pessoa assim, limpa, uma pessoa suja, isso aí vai trazer doenças, essas coisas, não vão fazer nada de proveitoso.

F 2 - Eu procuro fazer a seleção, eu mesmo, em casa, faço na hora de distribuir o lixo, de botar o lixo na porta para o carro levar. Eu sempre coloco em sacos diferentes, não boto assim tudo misturado porque nós, fazendo isso, estamos beneficiando a nós próprios.

F 3 - Eu tenho muito a ver por conta de manter a Universidade limpa. Eu sinto falta de não ter um aproveitamento melhor desse lixo e acho que a gente tem que caminhar para isto. A gente tem muito desperdício, embora tenha coleta seletiva, a gente joga muito lixo fora, poderia ser muito mais aproveitado

F 4 - Tenho a ver no sentido de doenças provenientes do lixo. A dengue aí, de latinha sem uso, a dengue e, mesmo, por você se sentir bem em lugar limpo. E mais ainda, em saber que este lixo está sendo aproveitado, reaproveitado e está beneficiando alguém ou algumas pessoas.

F 5 - Eu acho que sim, todo mundo tem a ver com o lixo eu acho que tenho, todo mundo tem. Em casa, mesmo, eu faço a separação, material plástico coloco em saquinho separado, restos de comida separado. Em casa eu faço a separação, vidros. 


\section{ANEXO 2}

\section{Programa de Educação Ambiental desenvolvido Arraial de São Francisco da Mombaça - Expressões-Chave}

1. Expressões-chave obtidas da pergunta: Fale para mim sobre o Projeto de Educação Ambiental desenvolvido em Mombaça. $O$ que você sabe sobre ele?

\begin{tabular}{|c|}
\hline Idéia Central: Sentimento sobre o projeto \\
\hline Expressões Chave \\
\hline $\begin{array}{l}\text { S1 - No início, esse projeto foi como uma bomba, foi uma coisa que eu jamais esperava que } \\
\text { fosse participar, que pudesse me relacionar e conhecer pessoas novas. }\end{array}$ \\
\hline $\begin{array}{l}\text { S } 1 \text { - O projeto veio para ajudar a gente a descobrir coisas novas como a forma de se relacionar } \\
\text { com as pessoas, com uma coisa que a gente tem sempre pavor, tinha sempre pavor de falar } \\
\text { sobre o lixo. Hoje a gente está conseguindo se relacionar até com ele }\end{array}$ \\
\hline $\begin{array}{l}\text { S } 1 \text { - Eu aprendi muito com esse projeto. Esse projeto veio, não sei se é a palavra certa, veio a } \\
\text { calhar na vida de muita gente, principalmente na minha, porque hoje eu sei muita coisa através } \\
\text { do projeto. }\end{array}$ \\
\hline $\begin{array}{l}\text { S3 - Olha, o projeto foi uma coisa, um acontecimento que chegou aqui aos poucos, foi se } \\
\text { alojando e foi tomando conta assim da gente, da imaginação da gente, da vida, das noites de } \\
\text { sono, entendeu? Para mim eu sinto assim: esse projeto desenvolvido aqui, parece até estranho o } \\
\text { que eu vou dizer, mas é como o primeiro namorado que a gente vê e aí bate aquela coisa forte } \\
\text { assim dentro da gente, mas sem explicação. Então, o projeto, para mim, foi isso, ele começou e } \\
\text { eu não estava entendendo direito o que era esse projeto. Aos poucos, eu fui conhecendo, fui } \\
\text { vivendo, participando, falando sobre tudo isso e cada vez mais ele ia tomando um lugar dentro } \\
\text { de mim, da minha consciência e foi se desenvolvendo e foi ficando cada vez mais bonito, o } \\
\text { entusiasmo foi crescendo, a vontade de desenvolver e de ver as coisa acontecerem. }\end{array}$ \\
\hline $\begin{array}{l}\text { S } 9 \text { - O projeto de Educação Ambiental é uma coisa muito boa, vem enriquecer a Mombaça, } \\
\text { vem dar uma experiência mais para a gente }\end{array}$ \\
\hline $\begin{array}{l}\text { S } 11 \text { - Para mim é uma coisa boa, é uma coisa que eu gosto, me interessa e que eu gostaria de } \\
\text { ver continuar andando }\end{array}$ \\
\hline $\begin{array}{l}\text { S11 - você dizer que gosta de viver bem e que vai viver bem e quer continuar com aquilo que } \\
\text { você ajudou a construir e organizar continue eu acho que é através da natureza. Eu não consigo } \\
\text { enxergar outra coisa a não ser através da natureza }\end{array}$ \\
\hline
\end{tabular}

\section{Idéia Central: O início do projeto}

\section{Expressões Chave}

S 2 - O projeto de Educação Ambiental começou com as pessoas que foram ao rio, quando chegaram, estava tudo secando,

S 2 - D. Selma começou a conversar, então é mesmo? Vamos embora descer para ver. E aí com isso ela desceu com a turma para olhar

S2 - o lixo também que era horrível, ali na frente da escola. Já veio outra preocupação, a gente vai ter que dar providência nesse lixo

S 4 - Olha o projeto de Educação Ambiental, pelo que eu me lembro, surgiu até antes do Projeto À Sombra de uma Jaqueira que D. Selma começou a falar na questão ambiental daqui do Arraial, onde se aproximou também da UNEB em Santo Antônio de Jesus, através do professor Rubens

S 8 - O projeto, ele começou com uma inquietação do pessoal sobre o amontoado do lixo, o 
cheiro que causava mal quando a gente passava, ele ia se arrastando, a coleta não era feita no tempo devido, crianças no meio brincando, catando coisas e não tinha aquele cuidado de lavar as mãos e muitas pessoas queixando, falando que o cheiro era desagradável.

S 8 - Com o Projeto À Sombra de uma Jaqueira abriu-se uma linha que toda essa preocupação da comunidade, da escola resolveu em vez de fazer um trabalho só com práticas leitoras, a gente saiu da escola para a comunidade

S 10 - O projeto foi uma coisa criada sobre o meio ambiente e foi feito através de um projeto $\AA$ Sombra de uma Jaqueira

\section{Idéia Central: Atividades realizadas}

S2 -Começou o inverno ele mandou mudas, foi até lá trouxe as mudas, e ai começou aquela empolgação, todo mundo, crianças, velhos, jovens, todo mundo a descer para fazer o replantio, também na fonte, porque ele deixou bem claro, se a fonte não tiver árvores ela seca

$\mathrm{S} 2$ - foi tendo aquela experiência toda da coleta, de pesar

S 3 - foi uma alegria tremenda, poder desenvolver todas essas atividades do plantio da beira do rio, de preservar os jardins, a limpeza, me preocupar com a limpeza da rua, a questão do lixo, da coleta seletiva, da compostagem

S 3 - foi três professores daqui para tomar esse curso de Educação Ambiental juntamente com o pessoal da UNEB.

S 3 - começou a aparecer pessoas falando na questão ambiental, dando palestras e chegou a ter, a gente começar a enxergar esse outro lado. Fazer os plantios de matas ciliares, começou a ver também as experiências de outros profissionais na área de Educação Ambiental

S4 - Depois disto começamos a discutir a questão do lixo da frente da escola, que era uma coisa que estava incomodando e a gente não sabia como a solução

S 8 - Começamos com a escola, conscientizando os alunos, do que era necessário fazer, o que poderia se aproveitar desse lixo, o que não poderia, as pessoas da comunidade nos seus fundos de quintal como deveriam limpar, como deveriam selecionar, o que poderia servir, ser útil para o próprio solo, para a própria terra que eles plantassem e correndo atrás da prefeitura para poder também nos ajudar, juntamente com a Secretária de Saúde na época, que também nos deu total apoio

S 8 - e Selma também como coordenadora do projeto foi até Feira para ver como é que se fazia o trabalho, eu fui junto para ver como eles trabalhavam

S 4 - Daí vem o pessoal da UEFS e começou também a mostrar para a gente como se faz a coleta seletiva; a gente não sabia o que era uma coleta seletiva, não sabia como separar, não sabia que tudo ali poderia ter um valor ou não ter valor nenhum

S 4 - fizemos a caracterização do lixo junto com especialistas da UEFS, fomos para as ruas fazer esse conscientização, e nisso tudo foi a parte agradável, onde a gente conseguiu fazer a transformada

S 8 - A Selma com o trator e o pessoal da comunidade saímos pegando aquilo era uma forma de mostrar que a gente queria uma coisa diferente, que a gente não queria o lixo naquele espaço

$\mathrm{S} 2$ - foi tendo aquela experiência toda da coleta, de pesar, com a comunidade toda envolvida, e aí fez aquela cartilhazinha que foi distribuída

S 4 - também começamos a fazer desenhos e ver de que forma a gente queria ver aquela frente da escola, que era uma coisa que estava incomodando

S 8 - fizeram a cartilha de conscientização, distribuiu nas casas, teve reuniões na escola e no salão várias vezes e começamos

S 8 - perto desse lixão se fez um jardim para mostrar a eles que aquele espaço poderia ser utilizado para outras coisas e não aquela coisa horrível que prejudicava.

S 9 - Teve algumas oficinas de reciclagem de papel, brinquedos, práticas leitoras, roda de costura e como lidar com o lixo. 
S 10 - foi importante o plantio na beira dos rios. Teve o plantio, teve a formação do jardim em frente à escola, teve um projeto de uma praça que não foi realizado ainda mas que talvez ainda venha a se tornar uma realidade

\begin{tabular}{|l|}
\hline Idéia Central:O projeto proporcionou a Mombaça \\
\hline \multicolumn{1}{|c|}{ Expressões-chave } \\
\hline S2 - lá no meu trabalho, os meninos já estão sabendo que não deve jogar no chão, que não deve \\
estar destruindo, e a escola também envolvida com esse processo. Tanto é que você vê hoje a \\
Mombaça antes e hoje, a gente já nota uma diferença, todo mundo tem aquela preocupação de ter \\
seu jardinzinho \\
\hline S2 - Antigamente era assim, você plantava hoje, quando fosse no outro dia podia ir lá que estava \\
arrancado. Hoje não, planta e lá fica, e todo mundo conserva. \\
\hline $\begin{array}{l}\text { S2 - o lixo também, eu to achando que ele está mudando, porque o pessoal tem um novo olhar, } \\
\text { devido ao falar sempre, sempre está reprisando a mesma coisa. Hoje em dia na rua que eu moro } \\
\text { todo mundo já coloca o seu lixo separado, o que é entulho bota numa vasilha e o que é para ser } \\
\text { reciclado em outra e aí quando a caçamba passa já pega }\end{array}$ \\
\hline
\end{tabular}

S 4 - a coleta seletiva ajudou muito a gente conhecer cada espaço, o valor de cada material, o que representa cada material e até a origem daqueles materiais

S 4 - a gente construiu a praça, fez todo aquele movimento, conscientizou a população que era a coisa mais difícil, as pessoas estavam começando a trazer o lixo separado, criamos a praça, criamos a compostagem, um dos espaços de compostagem, espaço do material reciclável

S 10 - A comunidade foi bem beneficiada com o projeto; hoje mesmo as pessoas têm uma outra conscientização sobre o lixo inclusive teve uma passeata sobre o problema da dengue e a partir de agora tem três dias de coleta de lixo semanal aqui na Mombaça. O povo está tendo outra consciência de como se deve tratar do lixo e é uma coisa ótima

S3 - Para mim esse projeto foi muito útil, porque me deu condições de rever a minha vida toda e começar de novo de onde eu parei, tentando aprimorar e melhorar cada vez mais o meu conhecimento. Trouxe de volta, através desse projeto, os meus escritos que eu gostava muito de fazer versos, de escrever pensamentos, e depois teve uma época que eu deixei, parei tudo isso, e com esse projeto eu me senti assim revitalizada

S3 - Eu acho que valorizou também muito aqui a comunidade com esse projeto, com essa associação

S4 - São Felipe já está querendo implantar também a coleta seletiva, a oficina de..., a usina de lixo, já está olhando também para esse lado ambiental, quer dizer devido ao trabalho da Mombaça que foi apresentado lá na jornada pedagógica com os professores e que isso despertou a curiosidade deles e a vontade também de lidar com essa área ambiental

S 4 - Coral Terra Viva foi surgindo, a gente envolvendo não só o canto lúdico, mas também envolvendo o canto do meio ambiente, o canto da gente aqui que é Mombaça

S 4 - Todo mundo pode ter compostagem no fundo do quintal e daquilo tirar alguma renda e aí é que dá o resultado, fazer as mudas de planta também e outra coisa que dá resultado é a reciclagem de papel que está sendo uma das coisas mais fortes que estamos tendo diante desta parte ambiental

S 4 - Mas o trabalho de conscientização acho que fica para cada um. O trabalho de conscientização não fica exposto; só fica exposto quando ele tem esta interação. Mas o que cada um aprendeu está dentro de cada um. Eu acho que quem está fazendo compostagem hoje no fundo do quintal, está fazendo porque teve um aprendizado em cima do que foi captado e os outros que faziam e não estão fazendo mais, porque desacreditou 


\section{Iléia Central: Projeto na Escola}

\section{Expressões-chave}

S 2 - Todo jardim que tem aqui e na frente da casa de algum estudante, pode ter certeza que os estudantes já tem aquela preocupação, não é?

S 7 - O trabalho de Educação Ambiental em nossa comunidade antes, talvez até pudesse saber alguma coisa, mas não era aquela coisa aberta para o público em geral da nossa comunidade principalmente a escola depois que o projeto começou a atuar os professores juntamente com os alunos e a família dos alunos se conscientizaram a respeito do que é um trabalho sobre o lixo, do que é um trabalho sobre a preservação da natureza e hoje a gente já vê a coisa tocando não no total desejo mas já aceitando a proposta de como trabalhar com a Educação Ambiental. Os trabalhos na escola chegaram com os técnicos de outras cidades e até com o de Feira de Santana, fazendo o trabalho da coleta seletiva, porque a gente não sabia trabalhar com o lixo selecionado e daí já foi deixando aberto como se trabalhar na escola com a compostagem: o próprio lixo orgânico que era retirado da merenda escolar que se fazia uso já se botava na composteira e também a limpeza na área da escola. Na área interna da escola as crianças não jogavam mais o plástico a toa, já tinha seu lugar selecionado e também a conservação do meio ambiente da escola já não se depredava mais as árvores, não acabavam mais com a jardinagem que era feita na própria praça.

S 8 - Ontem eu pedi uma pesquisa para os meninos fazerem na escola e dentro dessa pesquisa eu falei: a gente vai trabalhar sobre a nossa comunidade o que é que tem nesse lixo, que vai para esse lixo que a gente passa todo o dia quando a gente vai para escola. Porque continua no mesmo lugar. O que pode ser reciclado e o que não pode ser reciclado. Então eles souberam dizer já o que era que podia ser reciclado, o que não poderia, qual a utilidade do vidro tinha, se o vidro o lugar era ali e eles já sabiam que não. Então, eles já tem uma consciência, embora eles não saibam reivindicar ou pedir para ser diferente, mas eles já sabem o que poder ser transformado, falou do papel, que pode ser feita capa de caderno, que pode reciclar papel, falou das coisas podres que vão ali que causam doenças, falamos da dengue, então essa consciência eles tem, do que é bom não está no desleixo, como a maioria dos pais deles falam: para que isso? eu sempre joguei lixo ali. Então eles já criam, a coisa boa é isso, porque já vai criando neles essa visão nova de que os pais deles não tinham.

\section{Idéia Central: Frustrações}

S 2 - O jardim da frente da escola, infelizmente teve aquele problema que a prefeitura deixou virar um montante

S 4 - O que mais frustrou na questão ambiental foi o entrozamento com o poder público, porque tivemos na gestão passada um certo apoio nesse lado, fornecendo as mudas de plantas, algumas vezes trazendo até os garis para que agissem com a gente nesta questão, acho que o entendimento deles eram errado. Eles achavam que aquilo poderia ser um absurdo para investirem na parte ambiental daqui, no lixo da comunidade, achavam que botando a caçamba, carregando de qualquer jeito era a forma correta

S 4 - Todo mundo participando numa boa, cantando, fazendo mudas, plantando a gente deixou a praça bonita, daqui a pouco pelo simples fato de não recolher o lixo a comunidade começou a desacreditar que aquilo poderia ser viável, que tudo só poderia se conseguir através do poder público e isso foi que deixou que a pracinha voltasse ao lixão de sempre

S 4 - hoje a gente passa na Mombaça, vê aquela caçamba passando e pegando os lixos nas portas, chegando nos mesmos locais onde tem os lixões, fazendo a coleta da mesma maneira que antes e porque não faz a coleta de maneira que a gente tinha conscientizado o povo, então isso, para a gente reabilitar essa ação novamente vai ser começar tudo do zero

S 4 - Quer dizer os garis vieram, pegaram as baias que tinham sido feitas no espaço, separando o lixo orgânico do lixo seco, levaram tudo junto e acabou aquele espaço 


\begin{tabular}{|c|}
\hline Idéia Central: Conheço pouco sobre o projeto \\
\hline Expressões-chave \\
\hline $\begin{array}{l}\text { S } 5 \text { - Eu conheci o projeto através de D. Selma, aí eu, que dizer eu não participo, mas só fui dar } \\
\text { uma olhada, eu gostei muito. Eu fui dar uma olhada ali no jardim, eu não participei, que nem me } \\
\text { convidaram, aí eu fui lá dar uma olhada, mas, assim todo mundo foi olhar, aí eu fui olhar, eu } \\
\text { gostei. }\end{array}$ \\
\hline $\begin{array}{l}\text { S } 6 \text { - Eu conheço muito pouco, porque pouco eu participo. Quer dizer eu fui chamada e tudo, mas } \\
\text { eu pouco participo, porque às vezes também quando tem qualquer coisa eu nem sei. Quando eu } \\
\text { venho saber já terminou. }\end{array}$ \\
\hline S 6 - Às vezes eu não posso ir também \\
\hline $\begin{array}{l}\text { S } 6 \text { - Aí quando tem qualquer coisa, às vezes D. Selma quando está aí me chama, me avisa, mas } \\
\text { nem posso ir, aí quase eu não participo. }\end{array}$ \\
\hline $\begin{array}{l}\text { S } 6 \text { - O projeto faz negócio de doce, artesanato, um bocado de coisa. Tudo que vem na cabeça do } \\
\text { povo, o povo faz. Minha menina sempre quando está aí, participa de reunião, mas eu é difícil eu } \\
\text { ir lá mesmo, no lado de baixo da rua. }\end{array}$ \\
\hline $\begin{array}{l}\text { S } 6 \text { - Para ser franca eu queria que tivesse um negócio para dar um trabalho a gente. Para a gente } \\
\text { ter um trabalho ali para dizer, eu estou trabalhando, eu estou recebendo. Agora o negócio só fica } \\
\text { nesse, nesse, não... É bom, porque os que elas estão, o que elas estão fazendo é bom, porque se } \\
\text { acontecesse de fazer isso que elas tão planejando aí era uma boa aqui para o lugar, que é um } \\
\text { lugar pequeno, mas por enquanto. }\end{array}$ \\
\hline $\begin{array}{l}\text { S 6 - O negócio de, o negócio do lixo agora é que está melhor, não está acumulando, isso aí já é } \\
\text { uma vantagem. Já está fazendo coisa aí, mas aí eu não sei explicar quase nada desse projeto, } \\
\text { porque eu não estou participando. Eu fui convidada e tudo, andei lá um dia ensinando um crochê } \\
\text { também e tudo, ma eu parei. Participar é para eu estar constante, né, com as outras, negócio de } \\
\text { doce tudo que elas fazem e tudo. A minha menina é que aprendeu um bocado, a minha menina } \\
\text { tem até o diplomazinho que trouxe de Feira, meu menino também participou em Feira e agora ele } \\
\text { está trabalhando em Salvador, mas quando ele estava aqui ele foi com o pessoal de D. Selma. }\end{array}$ \\
\hline
\end{tabular}

\section{Expressões-chave obtidas da pergunta: Na sua opinião o projeto mudou alguma coisa em Mombaça? Fale sobre isto.}

\section{Idéia Central: Mudou em relação ao lixo}

\section{Expressões - Chave}

S1 - Mudou porque hoje a prefeitura já manda o carro pegar pelo menos duas vezes ou três na semana e os saquinhos já estão amarrado na porta de casa

$\mathrm{S} 1$ - Mudou, mudou em relação aos professores, mudou $\mathrm{em}$ relação à comunidade $\mathrm{O}$ pessoal antigamente não tinha consciência, eu queria dizer vivia o lixo muito a toa

S1 - colocavam o lixo na porta do colégio, então através de reuniões, de ... tipo uma passeata, nós catamos o lixo de porta em porta, entregando saco ao pessoal e fazendo com que eles tivessem consciência de que o lixo traria problema, causaria doenças. Hoje eles já estão deixando na porta de casa o lixo amarradinho, apesar de que tem aqueles que ainda colocam no mesmo lugar de antigamente, mas são poucos, não são todos porque é difícil a gente conscientizar o pessoal, uma comunidade inteira em pouco tempo, eu acho que é uma coisa longa de acontecer, mas mudou sim S4 - Mudou, o projeto mudou porque eu mesmo fui uma das pessoas que mudei junto com o projeto, o meu crescimento veio junto com o projeto, porque eu gosto, eu gostava do plantio; via no meio ambiente pouco resíduo sólido, gostava mesmo do mesmo replantio, mas a questão do lixo não tinha muito olhar para esta questão do lixo, então em cima disto fui criando novos hábitos em relação ao meio ambiente, ao nosso ambiente aqui, não só na questão do plantio, mas na questão da própria coleta que eu não conhecia.

S4 - Comecei a conhecer através do projeto, em relação mesmo à compostagem, eu acho que 
muita gente mudou junto com isso.

S4 - Hoje para muitas pessoas fica claro o que é lixo seco, o que é lixo molhado, que eles aqui conhecem mais como o lixo seco e o lixo molhado. O molhado é orgânico e o seco, inorgânico

S4 - Mostrou isso tanto para crianças como para idosos, a forma que a gente pode lidar e que não só a forma de quem trouxe de fora, mas da maneira também que poderia criar, o que já vinha fazendo também era a forma correta.

S4 - Eu vejo que até os mais novos aprenderem mesmo na questão da reciclagem de brinquedos criativos com sucata, com o plástico mesmo, como a transformação do plástico que a maioria não sabia nem de qual era a origem do plástico, de onde se tirava o plástico, hoje já tem essa noção. Não sabia que o material orgânico poderia virar adubo, que isso poderia ser comercializado,

S4 - foi abrindo também novos campos para a comercialização, para o emprego, porque se hoje a gente não tivesse aprendido com o pessoal da UEFS, com outras pessoas que também passaram por aqui mostrando a parte de reciclagem, a parte de Educação Ambiental como se recicla o papel, se o papel que ia ser jogado fora pode se reciclar, se o papel que ia se jogado fora pode ser reaproveitado e ter um valor comercial, pode dar sobrevivência a algumas pessoas através disso. $O$ adubo orgânico também é da mesma forma, ninguém sabia fazer a compostagem, pode ser comercializado, então esse aprendizado, quem absorveu esse aprendizado

S4 - Hoje aqui não tem mais campo de fumo e as pessoas ficam lamentando, porque tinha e hoje não tem, quer dizer hoje o fumo não pode dar resultado, mas o papel hoje a gente está vendo que está dando resultado, começando no mínimo achar que dá resultado.

S8 - Mudou porque, veja bem, eu mesmo aqui em casa, antes a gente pegava o lixo, tinha um buraco enorme, nesse buraco ia tudo. Era escavado bem fundo, quando enchia comparava gasolina e botava fogo e ele ia baixando, e a gente continuava jogando. Quando não era possível mais jogar, fechava e abria-se outro, então mudou. Aqui mesmo separa-se o que é orgânico e inorgânico e se queima só papel do sanitário, o papel higiênico ainda se queima.

S8 - já serve como adubo para as minhas plantas, já botei adubo nos pés da laranjeira então mudou e não foi só aqui, foram várias outras pessoas daqui que conseguiram no fundo do quintal fazer sua compostagem.

S8 - Então além da consciência dos adultos, mais importante foi a consciência das crianças para estar levando isso com elas. Então elas já têm o cuidado de quando jogam, eles já sabem que aquilo é desagradável, que aquilo pode causar doenças, vários insetos transmissores, que o vento pode levar aquelas coisas todas

S9 - Bastante, mudou a forma assim, o povo não se conscientizou do processo do lixo, mas do que era antes a Mombaça mudou bastante.

S9 - Antes a quantidade de lixo na Mombaça era grande mesmo, agora é pouca, já reduziu bastante a quantidade de lixo.

S9 - A gente tem aquela coisa de estar ensinando o povo o que o lixo, como separar o lixo, como organizar o lixo nos seus quintais, porque o lixo é prejudicial a saúde, as doenças que ele traz, o povo sabe que o lixo é um problema muito grande no Brasil e no mundo inteiro então eles estão se conscientizando bastante então o que era a Mombaça de lixo estamos andando e a caminhada é grande. 
S9 - As pessoas estão fazendo compostagem; eu estou lidando agora com biodigestor e a gente está ensinando isto, a compostagem veio em boa hora porque antes a gente jogava o lixo orgânico na rua e no próprio lixão e agora o povo está sabendo como aproveitar o lixo.

S11 - Mudou que a gente sente que as pessoas não têm dificuldades em assimilar o que se propõe. Agora tem que estar acoplado a outro assunto, as vezes você só fala sobre o projeto ambiental e se não tiver acoplado a outros assuntos, econômico e a qualquer coisa termina a comunicação ficando difícil.

S11 - Tem que estar acoplado uma coisa com outra porque o lugar é carente se não fosse carente a comunicação seria mais fácil. Agora o que tornou a comunicação satisfatório foi justamente o lugar pequeno e o pessoal de uma hora para outra viu que o lixo é um problema.

S11 - Foi se criando um lixão aqui outro ali e o pessoal via que estava se criando lixo como era o lixo antigamente, que tinha pouco detrito inorgânico e ele imediatamente se decompunha sem criar problema mas quando entrou esses problema de muita lata, muito plástico o pessoal viu que aquilo era um problema, um problema que crescia de uma maneira que a pessoa não imaginava que o crescimento era aquele.

\section{Palavra Chave: Mudou em relação às pessoas da comunidade \\ Expressões-chave}

S1 - Mudou, mudou em relação aos professores, mudou em relação à comunidade

S2 - Mudou, mudou a consciência das pessoas, mudou o jeito assim do estudante ver e criou ânimo, que até as pessoas idosas voltaram a estudar,

S2 - mudou o olhar das pessoas, mudou muito mesmo, até $\mathrm{em} \mathrm{mim} \mathrm{buscar} \mathrm{a} \mathrm{aprender} \mathrm{algo} \mathrm{para}$ poder sobreviver. Quantas pessoas aprenderam a fazer crochê durante o primeiro período do projeto, fazer colchinha de retalho, quantas professoras tão querendo aí estudar mesmo para fazer vestibular, querendo aumentar o grau de conhecimento.

S2 - Mudou, o projeto foi assim como uma gota d'água no oceano, foi uma maravilha mesmo, criou uma nova expectativa de vida nas pessoas daqui.

S2 - As pessoas daqui aprenderam a ter esperança, acreditar que o que sabe, mesmo não tendo nível superior, o que sabe é capaz de mudar a história.

S3 - Mudou, eu acredito que mudou. A começar pelas crianças. As crianças de agora estão valorizando mais as coisas, estão mais conscientes do seu valor dentro da escola, na sua criatividade, estão mais participantes, prestam mais atenção quando a gente fala.

S3 - Eu acho que mudou muito e também a respeito da visão local, as pessoas já tem um ponto de referência dentro da comunidade, já tem associação comunitária,

S3 - Antes era mais difícil a comunicação. Agora a gente já tem uma facilidade, já tem como ponto de referência lá o salão paroquial

S3 - A gente desenvolveu bastante até a própria linguagem

S3 -A gente está mais desinibido, a gente também aprendeu a conversar mais claramente

S3 - A capacidade de raciocínio das pessoas que freqüentam, que participam da associação agora, está tendo uma visão bem mais ampla do que se tinha antes.

S5 - Mudou, mudou bastante. Mudou muitas coisas. Ali um bocado de menino que não sabia nada assim, fazer crochê e bordar, que não bordava, os meninos não tinham assim em que bordar, os meninos fazer pintura, fazer... brincar de fazer arte, de fazer toda semana arte, um bocado de coisa.

S7 - Mudou. A visão do povo não é mais a visão do passado, já sabe mais ou menos o que é uma Educação Ambiental, o que é plantar, o que é deixar para conservar, não é derrubar por derrubar hoje já se tem consciência. 
S7 - Antes eu achava que a própria prefeitura se incumbia de fazer o trabalho de podação, de plantação de canteiros de jardins na pequena praça que nós temos na comunidade, mas hoje os próprios moradores depois desse trabalho eles mesmos já vão lá e preparam seu canteiro.

S10 - Mudou no sentido da conscientização da população no sentido da conservação do solo,

mudou tudo no sentido geral, o povo está muito mais consciente

\section{Idéia central: Mudou em relação às áreas verdes}

\section{Expressões-chave}

S7 - Antes eu achava que a própria prefeitura se incumbia de fazer o trabalho de podação, de plantação de canteiros de jardins na pequena praça que nós temos na comunidade, mas hoje os próprios moradores depois desse trabalho eles mesmos já vão lá e preparam seu canteiro.

S1 - Hoje Mombaça tem muito verde que não tinha antes, certo já surgiram mais jardins, já, até as crianças vocês vê que na porta de casa, de cada casa já tem um pequeno jardim feito pelas próprias crianças da comunidade, estão isto é muito importante.

\section{Idéia Central: Não estou vendo mudança}

\section{Expressões-chave}

S6 - Para ser franca eu não estou vendo nada ainda de mudança, a não ser o negócio do lixo, que pelo menos tão, deram em cima, deram em cima, que pelo menos estão tirando. Nada tem feito, ainda, não tem um local de trabalho para ninguém, é o que eu posso dizer é isso. 


\section{Expressões-chave obtidas da pergunta: Houve mudança pessoal em relação ao projeto?}

\section{Idéia central: Mudou porque eu não sou a mesma pessoa. \\ Expressões-Chave}

S1 - Olha eu acredito que principalmente dentro de mim mudou muito, é como eu te disse no início, eu nasci aqui, eu nasci cuidando da terra e achei que sabia tudo e através do projeto eu descobri que nada eu sabia

S1 - Então mudou muito dentro de mim eu consigo me relacionar melhor até com as pessoas através desse projeto.

S1 - O estudo também, foi meio forçado, eu sou uma professora leiga. Aí eu voltei a estudar, então ajudou muito porque hoje eu já levo coisas do projeto para dentro da minha escola

S1 - Eu gostaria muito de falar também sobre a leitura, que hoje eu aprendi a ler, antes eu lia por ler e também acredito que nem sabia ler, porque eu aprendi a ler, a fazer a leitura visualizada, é aquela coisa de você, só de você olhar, você sabe ler. Hoje eu tenho prazer em pegar um livro, ler e escrever sobre ele, sobre o que eu li, é uma coisa que aprendi dentro do projeto

S2 - Eu acredito, o projeto foi e está sendo para mim uma maravilha. Eu tive a oportunidade de aprender muita coisa e a cada dia que passa eu aprendo mais, e tudo quanto que é coisa que aparece, o que diz assim tem a possibilidade de fazer, eu vou logo dizendo, eu não tenho universidade, mas o que eu puder dar de mim no que eu tenho em leitura, em procurar pesquisar para saber mais para poder chegar lá adiante num... também estar a par do que está acontecendo para discutir, questionar e estou aí.

S3 - É para mim isso foi uma abertura muito grande, me beneficiou muito e continua me beneficiando, porque até os estudos eu voltei a retomar através desse projeto que eu senti a necessidade de ter um desenvolvimento maior, de aprimorar mais a minha cultura também.

S4 - Olha o projeto mudou, para mim foi uma transformação de vida, porque eu mesmo cresci junto com o projeto. Hoje eu sou procurado, tenho esse reconhecimento, não só aqui mas até a nível nacional.

S4 - Estou sobrevivendo hoje também em cima do que aprendi. Porque hoje estou dando aula de canto, porque o projeto proporcionou a vinda especialista em música. Hoje posso chegar, falar de compostagem, do material orgânico, porque teve especialista que veio para mim, para mim repassar também esse aprendizado. Hoje eu posso falar também no replantio, porque teve pessoas que vieram repassar isso em relação a isso.

S8 - Nessa questão ambiental, não deixa de provocar mudança, porque sempre o que vem de diferente e santo de casa não faz milagre.

minhas críticas não são tão ferrenhas porque sei que as coisas não são fáceis. Porque antes eu criticava muito e a gente tem que ver que esses problemas de Educação Ambiental são coisas sérias e não estão dispostas a gastar dinheiro, e a gente

sabe que precisa de dinheiro para fazer uma coisa bem feita

S8 - Mudou porque aprendi muita coisa, consigo separar, não vou dizer nem separar, mas as,

S9 - Provocou bastante. Eu antes era uma pessoa comum, agora eu não sou mais uma pessoa comum porque desde que o projeto iniciou, minha vida já mudou bastante. Eles vêm ensinar muitas coisas boas e eu estou esperando cada dia mais quando o projeto ressurgir de novo eu espero que ele traga muita coisa boa.

S10 - Em mim mudou, tomei consciência de mais coisa que não tinha, não só do meio ambiente mas o convívio com outras pessoas também me ensinou bastante coisa, como a gente conscientizar das coisas.

S10 - Antigamente pelo fato de ser menos esclarecida a gente ficava sem falar, ele vai responde mal e eu não vou gostar. Hoje a gente já tem um preparo, mesmo que as pessoas nos respondam mal, a gente vai persistindo naquilo e tem um preparo psicológico para não se aborrecer por tudo, está me beneficiando muito 


\begin{tabular}{l}
\hline Idéia central: Mudou minha atitude em relação ao lixo \\
\hline \multicolumn{1}{|c|}{ Expressões-Chave } \\
\hline S1 - Eu achava que dentro de casa estando limpo, fora não precisava estar muito e hoje já \\
mudou muito você hoje já encontra na minha casa uma compostagem, você já encontra mais \\
plantas que não tinha, mais árvores, verde \\
S7 - Claro, dentro de mim eu já estou totalmente inspirada nessa visão, já gostava da natureza \\
antes e agora mais ainda. Hoje já sei plantar na minha casa, já sei preparar o meu adubo \\
orgânico no meu próprio fundo de quintal, você pode chegar lá e ver tudo arrumadinho as \\
plantinhas no caso alface, hortelã, coentrinho, temos semeado e com o nosso próprio adubo \\
feito em casa. \\
S8 - De entender, de valorizar as coisas que podem ser aproveitadas que a gente joga fora, eu \\
nunca tinha visto reciclagem de papel, nunca tinha visto eu nem sabia, o bambu faz papel, eu \\
nunca imaginava que papéis que você não usa mais pudessem se transformar em outros papéis, \\
bonitos com beleza singular deles \\
S9 - Antes eu não pensava quando eu via uma lata comum no lixo eu não sabia que podia se \\
transformar em brinquedo de sucata, não sabia que o restos de comida, essa coisa orgânica, se \\
transformava em adubo para as plantas, também não sabia que o cocô do boi e água misturado \\
fermentasse e produzisse gás butano, então isto é uma transformação que veio em boa hora \\
para mim se conscientizar mais das coisas e para me introduzir em um mundo que a gente hoje \\
vê que não está oferecendo muita coisa boa mas a gente tem que aproveitar as coisas boas que \\
ele oferece. \\
S11 - Mudou porque eu já fazia alguma coisa lá no fundo do quintal mesmo e procurei fazer de \\
uma maneira mais organizada
\end{tabular}

\section{Idéia central: Não mudou} Expressões-Chave

S5 - Não, porque eu nunca participei dessas coisas. Quem é mais, é o jovem que faz essas coisas, que tem negócio de canto, assim os jovens assim que faz para cantar, aí eu nunca me chamaram. Também não tenho voz.

S6 - Minha vida tá no mesmo. Porque aqui, que nem eu digo, é um trabalho que é um trabalho já para pessoa que tivesse, fosse fazer abrir uma fabricazinha qualquer coisa para pessoal trabalhar, porque aqui não tem trabalho, onde tinha trabalho era num campo que tinha aqui, era até meu marido que tomava conta, mas depois que acabou esse trabalho... quem trabalha fora, trabalha, aqui só é o lugar dos aposentados quem é, quem não é está mal. 


\section{Expressões-chave obtidas da pergunta: Você participa de alguma forma neste projeto? Fale-me sobre isto.}

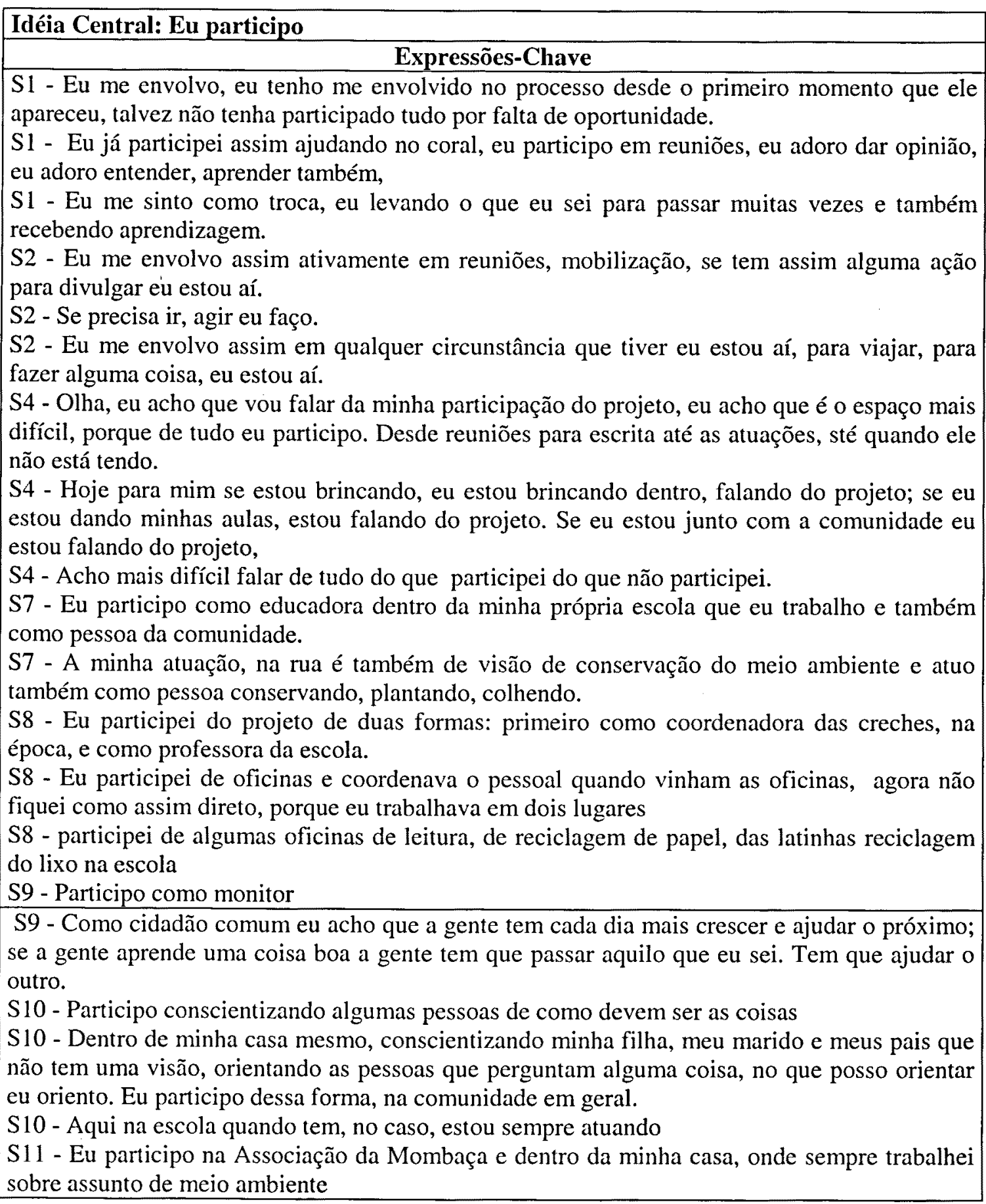




\begin{tabular}{|l|}
\hline Idéia Central: Às vezes eu me recuso a participar \\
\hline Expressões-chave \\
\hline S1 - As vezes eu me recuso a participar porque eu me chateio, as vezes quando a gente fala a \\
verdade cria certos tipos de problemas. Eu me chateio com coisas erradas que a gente vê é, tipo \\
de...por exemplo se acho que se tem uma coisa, eu acho não tenho certeza, porque associação \\
quer dizer associar. Todo mundo se tem uma venda, tem uma prestação de conta; se está na \\
hora da reunião dos problemas, se a gente está junto, se tem um passeio, eu acho que todo \\
mundo tem de ser comunicado, e as vezes isso, isso é... a gente não sabe, então quando a gente \\
sabe já foi, já voltou. Às vezes acontece o projeto paga um passeio e a gente não sabe, se é um \\
passeio que tem para gente tirar dinheiro da gente, aí já vem na porta convidar, e são essas \\
coisas que eu me recuso, eu acho isso muito chato, eu acho isso muito irregular.
\end{tabular}

Idéia Central: Não participo

S5 - Nenhuma

Expressões-Chave

S6 - Não participo das reuniões. 


\section{Expressões-chave obtidas da pergunta: Em que aspecto o projeto poderia ser melhorado? Fale-me sobre isto"}

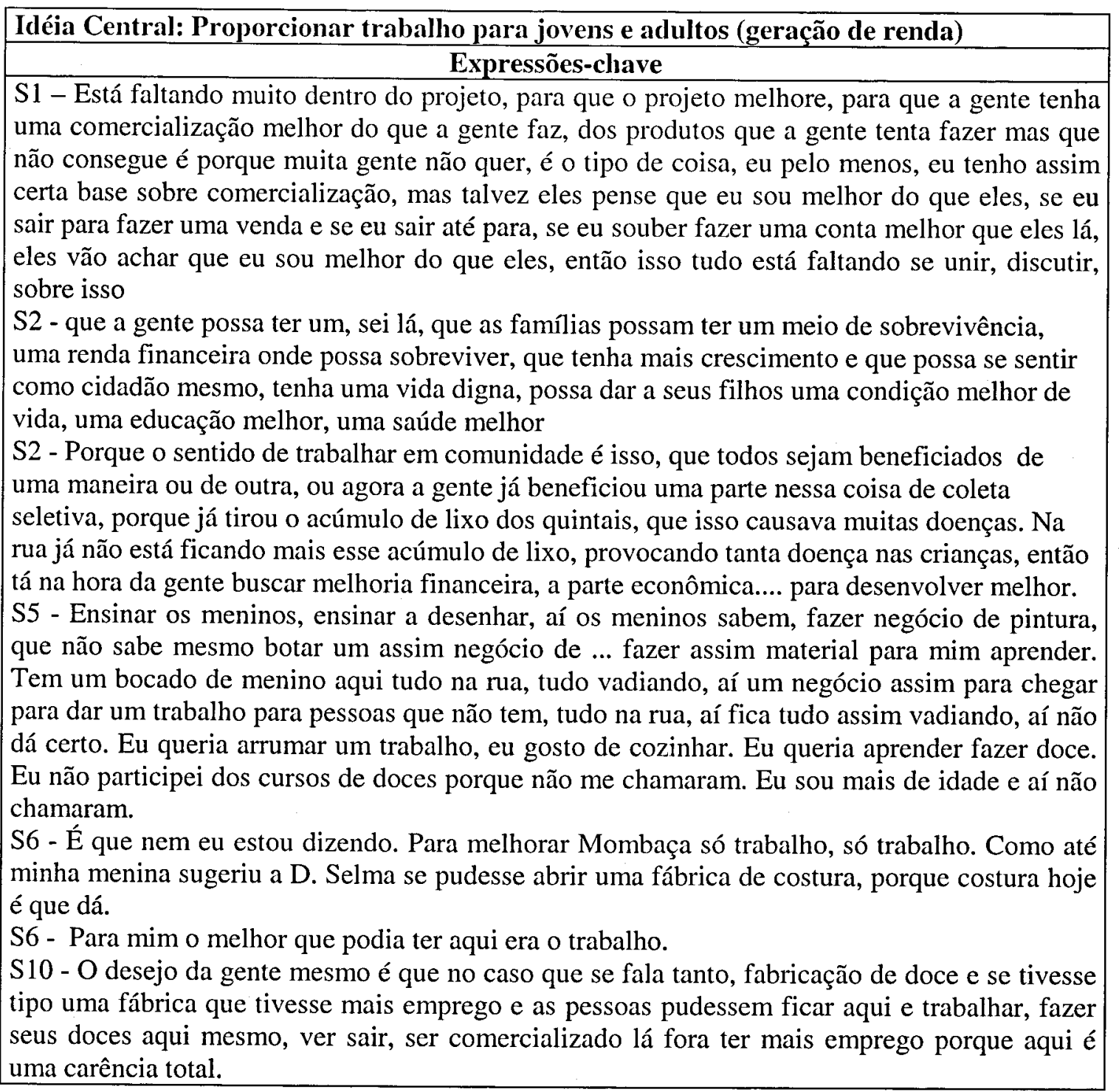




\section{Idéia Central: Desenvolvimento comunitário/envolver toda a comunidade através de um projeto de interesse geral}

\section{Expressões-Chave}

S3 - Olha, o que eu acho que falta no projeto é desenvolver a parte comunitária, porque o projeto que nós tivemos ele foi mais voltado para a escola, apesar da comunidade participar também

S2 - É preciso que a gente desenvolva um projeto aqui, que a comunidade em si, possa participar, independente do ponto de vista de cada um, sem exceção e que traga também atividades para o pessoal local, que eles possam sentir que também têm compromisso e têm uma atividade a desenvolver dentro da comunidade. Não ficar só assistindo o que as outras pessoas estão fazendo, mas eles participarem juntos, a gente trabalhar junto, como a gente fez no plantio das árvores na beira do rio que foi uma participação coletiva,

S2 - Então eu acho que isso é que está faltando aqui, que venha um projeto para a escola, que venha um projeto para a comunidade e que possa desenvolver para poder dar crescimento também, principalmente as famílias.

$\mathrm{S} 2$ - fortalecer mais as bases, as pessoas que sustentam devem ter assim mais envolvimento e aumentar a participação. Porque já tem um monte de gente participando, mas precisaria de mais pessoas

S2 - também lazer porque a gente não pode viver também sem lazer.

$\mathrm{S} 2$ - a gente tem que buscar, que descobrir junto com a comunidade alguma coisa que possa beneficiar eles também.

S4 - Olha, eu acho que o que está faltando no projeto é a interação da comunidade, o desenvolvimento da comunidade, juntamente com o grupo da Associação, porque muitas pessoas aqui, às vezes perguntam: o que é que a Associação? O que é que a Associação está fazendo? Aí a gente, o que a gente responde não agrada na maioria das vezes porque ouviu falar que em tal lugar, em tal lugar tem uma Associação que conseguiu uma casa de farinha, que conseguiu um poço artesiano e que aqui a gente não mostrou nada disso ainda. Mas eu acho que o nosso objetivo é não trazer uma receita pronta, mas trazer um trabalho de base, onde as pessoas possam estudar aquilo, ver de que forma pode ser feita, para que daqui a pouco, estar fazendo uma coisa e ter pouco sucesso.

S4 - Então o que está faltando para nós aqui é isso, o reconhecimento da comunidade em relação à educação e as ações que a gente está desenvolvendo, mas isso, como a gente pode fazer isso?

S4 - Então para mim o que está faltando é isso, atrair a comunidade para a Associação

S8 - Na primeira etapa a gente engatinhou e nesse engatinhar a gente foi percebendo que precisava de outras coisas que não podia ficar só em práticas leitoras sem olhar as coisas que estavam ao nosso redor, quer dizer a gente ficava só na escola, e fora da escola?. A gente também teria que dar uma vez, uma chance para as pessoas para eles compreender, entender o que estava se passando dentro da escola

S10 - Quando teve o projeto daquela pracinha foi um sonho para todo mundo porque aquela pracinha se tivesse sido colocada em prática seria uma grande realização mas ficou só o desejo, o sonho e aí parou, foi uma coisa que no papel. Se realizasse seria uma grande coisa para aqui, aquele lixão não estaria ali, fez-se o jardim o pouco que ficou não foi em frente.

S10 - Acho que deveria colocar coisas mais práticas sair da teoria, seria melhor para a conscientização da comunidade em geral. A gente vê muitas pessoas dizerem assim: só fala, só fala e a gente não vê nada, a gente que tem mais visão da coisa está vendo as coisas mas o povo $\mathrm{em}$ si não aceita muito não, por isto achei errado. O que falta é só um pouquinho de prática para ter a conscientização, porque enquanto a gente não vê prática mesmo aqui fica difícil.

S11- Então o importante é você fazer um trabalho que mostre os resultados, o mais breve possível, porque é a única maneira de você convencer a população do que você está fazendo 


\section{Idéia Central: Buscar apoio dos órgãos públicos e instituições \\ Expressões Chave}

S7 - Eu acho que faltou um pouco também dos órgãos públicos. Eu acho que os órgãos públicos não se direcionaram, porque a nossa força era muito mais forte, nosso desejo de atuação era muito mais forte e eles ficaram meio dispersos, não por nós não convidar, o projeto não chegar até eles, porque realmente que o trabalho era de Educação Ambiental, então faltou interesse dos órgãos públicos.

S7 - De apoio porque no caso não só depende de estar com o pessoal da escola e da comunidade porque o trabalho para ser tocado em melhores condições eu acho que a prefeitura devia estar incumbida de alguma coisa. Pela coleta do lixo, não posso dizer que não está fazendo coletivamente no meio da semana duas, três vezes na semana mas faltou alguma outra coisa.

S8 - Para seguir o projeto eu acredito que precisa de apoio, de uma alguma entidade que esteja disposta a dar continuidade ao trabalho que já está começado, que já está conscientizado e que a gente precisa de pessoas que se mobilizem esses empresários, porque o problema não é só nosso, mais deles também, mais do que nosso, porque quem fabrica as garrrafinhas, os sacos plásticos não somos nós,

S8 - Que apareça alguma entidade que esteja disposta a trabalhar que o pessoal daqui tem boa vontade,

S 8 - Que melhore e que não seja duas vezes a prefeitura trazendo caminhão para levar o lixo, porque o que realmente a gente quer é que tenha um destino correto para o lixo da nossa comunidade.

S11 - Do lixo aqui é como estava querendo dizer, há dez anos atrás, você não via esse problema na Mombaça e depois quando começou a se criar lixões e depois eles se assustaram e viram como cresce, como o lixo cresce e como aqui é um lugar pequeno, ainda dá para chamar atenção e isto foi bom porque despertou interesses nas pessoas, em quererem resolver aquele problema

S11 - E aí chegou Selma, depois a Associação, depois chegou o pessoal da Universidade de Feira que deu aquele apoio para desenvolver aquele trabalho e quando chegou na hora $\mathrm{H}$ mesmo o apoio oficial que precisava mesmo, não foi recebido e o que se fez ficou parecendo como se nada fez e como quem estava fazendo não sabia fazer nada, mas não foi pela pessoas que fizeram, foi pela divisão política. Então embora não ficou bem para o projeto, não ficou bem para a Associação e para outras pessoas envolvidas, mas ruim mesmo ficou para quem não soube aproveitar que foram os órgãos oficiais.

\section{Idéia Central: Sede Própria}

\section{Expressões-chave}

S2 - Eu acho assim, só o que falta no projeto é estruturar as bases, tipo assim, a gente não tem sede própria aí trabalha no salão paroquial e aí o pessoal acha assim, não entende que tá ali emprestado para a Associação por um período. Mas tudo o que a gente tem que fazer lá tem que pedir a permissão do padre. Então eu acho assim o que falta é um dia ter sede própria.

S9 - Era ter uma casa que abrigasse a Associação, todos esses trabalhos, essas reuniões que tem e um aspecto que o projeto poderia oferecer também era a rede de computação para poder se informatizar, ter uma casa que a gente trabalhasse com mais segurança com equipamentos certos, é o que espero quando o projeto renasça que ele traga para a gente. 


\begin{tabular}{|l|}
\hline Idéia Central: Falta de comunicações e reuniões antecipadas \\
\hline \multicolumn{1}{|c|}{ Expressões-Chave } \\
\hline S1 - Como eu acabei de te falar, está faltando mais é... o grupo se unir mais, está faltando, falta \\
de união no grupo, falta de comunicação \\
S1 - Nós não reunimos como deveriam e por exemplo, se tem algum coisa para acontecer, se \\
nós vamos reunir com D.Selma sábado, então seria gratificante até para ela se a gente se \\
reunisse sexta, discutisse o problema e quando ela chegasse, a gente já tivesse alguma coisa \\
mais objetiva para entregar a ela. No entanto nós ficamos esperando ela chegar sábado aí a \\
gente vai reunir, se tem algum problema maior a gente vai tentar discutir aos sábados, quando \\
ela volta já é 15 dias depois, então tudo dificulta
\end{tabular}

\section{Expressões-chave obtidas da pergunta: Lixo, você tem alguma coisa a ver com isto? Fale-me sobre isto.}

Idéia Central: Tenho tudo a ver pois minha relação com o lixo mudou

\section{Expressões Chave}

S1 - Lixo para mim é uma palavra muito forte que fica guardada dentro de mim, que eu estou conseguindo, até que hoje eu não vejo assim o lixo como lixo, eu já vejo o lixo como uma coisa boa.

S2 - Ah! Eu tenho, tenho muito, agora lixo, o lixo é que nem se diz uma frase, o lixo virou um luxo. Porque todo canto que eu vou eu falo. Falo e se vejo: Ah! Não joga no chão não. Os meninos de casa, da escola, da creche, já sabem. Se você for na escola você não vê lixo a toa. $\mathrm{Na}$ creche a mesma coisa, até o pessoal da cozinha sabe.

S2 - Uma cidade limpa não é benefício para quem está na prefeitura é um benefício para gente próprio, que a gente vai se tornar cidadãos organizados, tenho feito propaganda.

S3 - Ave-Maria! O lixo, o lixo hoje não é o lixo. O lixo hoje já não é lixo porque do jeito que a gente está tratando o lixo, a gente nem pode dizer mais que o lixo é lixo. A gente não pode mais nem dizer que o lixo é lixo porque já tem tanta coisa hoje aproveitável dentro do lixo e que a gente pode reciclar então. O único problema ainda do lixo é o plástico, porque ainda não se tem um destino certo para ele.

S3 - hoje já o lixo que existe mesmo é o vidro, o plástico, a lata, o flander, porque também é outro que a gente não tem um destino certo para ele, ainda não encontrou o ponto de comercialização e fica difícil da gente acumular ele no quintal, porque chega um momento que a gente não tem mais condições de ter aquele acúmulo e tem que botar fora mesmo

S3 - A comunidade aqui mesmo já está se sentindo mais beneficiada com isso, porque já tem uma visão mais bonita, os quintais mais limpos, a rua também mais limpa e o aproveitamento que a gente faz também está vendo resultado nas planta, o adubo, a compostagem, o húmus, a gente já está vendo aí o resultado, porque a gente já não vai comprar adubo para colocar nas plantas, ou nas roças, na plantação da lavoura, porque quem mora na roça pode fazer a compostagem e já tirar dali para botar para fazer o plantio

S3 - Nós mesmos quando começamos com esse trabalho da compostagem a gente tinha assim um plano da gente poder fazer uma horta comunitária, onde a gente pudesse ter não só frutas, como verduras, todos com produtos orgânicos para o desenvolvimento dos Sabores da Terra, da fábrica de doce, mas isso ainda não foi possível, mas a vontade da gente, o nosso sonho é esse para o futuro, a gente conseguir depois da...sede própria, da associação a gente ter um local onde possa desenvolver essa horticultura.

S4 - Olha, eu acho que tenho tudo a ver. Eu hoje como tinha falado que até um papelzinho de bombom eu não consigo mais jogar na rua, porque eu fui sensibilizado com isso. Hoje perto da minha casa tem um lixão que eu não jogo mais meu lixo, já não vai mais para o lixão. Já fica a parte orgânica no meu quintal, fazendo a compostagem e no saquinho plástico vai o que não 
pode ser reciclado. Porque aqui não tem como a gente reciclar esse outro lixo, a não ser o papel S5 - Ah! Lixo mudou bastante, depois desse negócio do projeto, que primeiro vinha nas portas, aí depois parou, agora a gente pega e joga dentro de um saco e bota ali, toda a semana pega. Ficou ótimo ficou bom.

S7 - Eu acho que o lixo é uma questão mundial. O mundo todo se preocupa com a questão do lixo, mas dentro da minha comunidade, uma comunidade de 800 a 900 habitantes, o povo já sabe o que significa o lixo, já tem uma consciência de como separar

S7 Eu tenho a ver com o lixo no geral, porque a gente vê que o lixo também pode gerar emprego, lixo pode gerar também inquietação a proporção que você no caso conscientize o homem em si ele pode ser um meio para sustentar sua própria família, depois que ele tem consciência. Antes da consciência o lixo é lixo mas depois que se conscientiza ele pode saber que é um meio sustentável para a sua família.

S8 - Claro que eu tenho eu sou dona de casa, sou professora, eu amasso papel, eu descasco verduras, tenho tudo a ver com isso. Todos nós temos a ver com isso, a maior preocupação de uma entidade, de um órgão executivo e legislativo não tem a ver só com eles tem tudo a ver conosco. Se a gente não tomar cuidado ele vai estar por cima da gente, tem tudo a ver.

S9 - Tenho, eu tenho a ver com o lixo porque trabalho com o lixo. Lixeiros são aqueles que não trabalham com o lixo mas sim aqueles que lidam com o lixo no bom sentido. Não que viva do lixo mas que tire do lixo aquelas coisas boas, as coisas que presta para fazer brinquedo, para tirar do lixo o composto orgânico e até tirar do lixo o próprio gás que agora a gente está fazendo que é o biodigestor. Então o lixo antes era meu inimigo agora é meu amigo porque eu me dou com o lixo e sei como lidar com o lixo.

S10 - Todos produzem lixo. Agora saber produzir e também saber como usar aquele lixo para não ser prejudicado e nem prejudicar a comunidade e usar o lixo como uma coisa agradável, no caso fazendo a reciclagem, não colocar o lixo orgânico na rua. Aqui, hoje, graças a Deus o pessoal colocava o lixo em qualquer canto e hoje a conscientização está melhor e o pessoal está procurando botar em lugar determinado.

S11 - Eu quando falo de lixo, primeiro prefiro olhar para dentro de minha casa se existir um trabalho, eu dentro de minha casa procuro desenvolver esse trabalho, agora se existe um trabalho que a comunidade queira desenvolver o apoio que eu puder dar eu dou.

S11 - eu não vou sentir totalmente realizado porque eu vou achar que a minha casa está tudo legal e quando eu boto o pé na rua não está tudo legal.

S11 - Eu estou procurando uma definição para o lixo e não achei. Eu procuro porque existe a parte do lixo que a lata velha se transforma em lata nova, o alumínio se transforma em alumínio, o vidro se transforma em vidro e a parte orgânica se transforma em adubo, então quando a gente diz é lixo, parece que você mistura tudo e nada serve para nada a não ser para pegar qualquer parte do ambiente natural e ficar fazendo tudo feio. Então até hoje eu procuro esta palavra realmente para me comunicar melhor e não achei, deve ser lixo organizado mesmo. Você mesmo sabe que a palavra lixo é muito pronunciada e eu sentia quando você pronuncia muito aquela palavra em vez de você atrair a atenção das pessoas termina não atraindo.

\section{Iléia Central: Não tenho nada a ver com o lixo}

\section{Expressões Chave}

S6 - O lixo é que nem eu estava falando que ficava acumulando em frente ao colégio, era uma coisa triste de junto do chafariz. Na verdade é que eu não pego água lá e nada mais achava uma coisa ruim aquilo ali. Jogava bicho morto, tudo ali era muito fedendo mesmo. O meu é cavado aqui mesmo, porque meu terreno é grande e eu queimo por aqui mesmo, nem jogo para lá, eu queimo aqui mesmo. Agora o negócio do lixo devia ter um lugar mesmo reservado só para o lixo mesmo. Que nem estão fazendo agora que está de qualquer jeito tirando toda a semana, aí fica tudo limpo, a não ser isso, para mim tá tudo... Não tenho nada a ver com o lixo, o problema 
daqui é coisa aqui mesmo, eu queimo tudo aí, e aí não posso falar nada sobre o lixo. 


\title{
ANEXO 3
}

\section{Programa de Educação Ambiental desenvolvido na município de Mucugê - Bahia - Expressões-chave}

\section{Expressões-chave obtidas da pergunta: Fale para mim sobre o Projeto de Educação Ambiental desenvolvido em Mucugê. $O$ que você sabe sobre ele?}

\begin{abstract}
Idéia Central: Projeto relacionado à Usina de Reciclagem, acertos e desacertos (o início, a desativação e o retorno).
\end{abstract}

\section{Expressões-Chave}

S1 - Para este processo da reciclagem foram feito vários seminários ainda na administração anterior e na implantação da usina. Foi feito um trabalho de conscientização da comunidade e até então eu era só moradora e participava como moradora e aí todo mundo selecionava seu lixo e deixava o saquinho na porta quando o carro passava tudo certinho. Depois a profissional responsável pela continuidade da Usina ela saiu, foi dispensada e daí começou todo o serviço caindo. O lixo, ninguém mais importava, ninguém exigia que o lixo fosse selecionado e foi bagunçando e caindo mesmo. Foi quando no segundo semestre de 2001 veio de novo toda esta vontade e preocupação de atuar de novo, quando foi buscado pela administração, contato de novo com Fátima, a engenheira responsável por este projeto.

S3 - A usina foi para recolher o lixo da cidade e transformar em adubo para a própria cidade, beneficiar a própria cidade.

S5 - Esse é um dos primeiro projetos da Bahia, este projeto de educação ambiental que é esse da usina de reciclagem. Muito interessante, no início, foi um pouco difícil porque causou um impacto quando chega um projeto desses, as pessoas não tinham muito costume de selecionar o lixo, então com o tempo foi melhorando. Depois teve uma recaída na mudança de prefeito e agora voltou a melhorar mais, o prefeito está empenhado fazendo novas reuniões com o pessoal, selecionando o lixo direitinho acho que está legal.

S7 - O projeto foi desenvolvido para cuidar do ambiente da região, limpar, deixar limpo que tem muitas coisas que são jogadas fora, sujando o ambiente e que pode ser aproveitado. $O$ projeto foi criado para isto para reaproveitar esses materiais recicláveis que o pessoal joga fora e está prejudicando o meio ambiente. Com esse projeto aí dá para aproveitar muito material.

S11 - Esse projeto iniciou com o pessoal da CAR e o pessoal começou colaborando no começo e acabou não colaborando mais. Pediam para separar o orgânico e inorgânico e acabou misturando o lixo mesmo. Depois deu uma parada. O pessoal estÁ tentando reanimar de novo este projeto.

S14 - Este projeto começou em 98 com a parceria da CAR, Prefeitura e Governo do Estado. A idéia imediata era limpar o meio ambiente por ser um local onde nós temos o Parque Nacional da Chapada Diamantina, onde hoje tanto o governo do estado como a prefeitura estão investindo no turismo. Se achou viável se fazer esta usina porque nas primeiras pesquisas foi constatado que a maior parte do lixo é orgânico que nós usamos para fazer adubo orgânico, que é natural. Eu acho que é um projeto que tem tudo para dar certo desde que a população contribua com sua parcela. Até agora nós estamos fazendo o possível para fazer dar certo, tanto por parte da CAR como por parte da Prefeitura, nós fazemos o possível para fazer dar certo. Acho muito importante porque hoje nós temos os pontos turísticos da cidade. A cidade de Mucugê é uma cidade que quem chega vê que é uma cidade limpa, muito bem cuidada o povo tem um padrão de vida muito bom e as pessoas que vem de fora se sentem bem, porque normalmente quem chega em algumas cidade, que não vou citar o nome de nenhuma, se depara com a sujeira, com o lixo jogado na beira da estrada aquele acúmulo de urubus, de doenças, de ratos e insetos. Mucugê não tem isto porque hoje todo o 
lixo da cidade vem para a usina e é todo selecionado, o material reciclado ele é prensado e armazenado e o orgânico vai para o pátio de compostagem e depois de um processo de 90 dias ele já é peneirado e já vira adubo e o expurgo que são coisas de higiene pessoal essas coisas de banheiro, pedaços de madeira, panos velhos essas coisas tudo isso vai para a valeta enterrado e a gente consegue manter isto limpo, acho muito importante. $O$ que posso dizer é isto e que infelizmente não está melhor devido a falta de colaboração de uma certa parcela da população. Mas nós estamos se movendo, a sociedade, a área da saúde e da educação todo mundo em prol de ir cobrando do povo o dia a dia para fazer um trabalho de corpo a corpo para ver se consegue esclarecer as pessoas e mostrar para eles que é importante a colaboração de todo mundo. Porque na verdade não se está visando o lucro financeiro mas um bem estar. Uma região limpa é uma região de bem estar muito grande com um padrão de vida muito bom.

S15 - Tem a usina de reciclagem e a gente está querendo montar com as donas de casa e com as empregadas, 'o maior problema está sendo elas na separação de lixo. O pessoal acha que o lixo colocado assim de qualquer jeito, mas não é assim. Tem a reciclagem de lixo e tem os dias alternados que eles pegam o lixo. Todos os dias pela manhã eles pegam os detritos, restos de verduras e uma vez na semana eles pegam latas, garrafas coisas que é reciclável. Então a gente está bem adiantado, passou um tempo com o negócio da política a usina quebrou uma peça lá e ficou mais de um ano. Mas agora já reativou de novo, já consertou e o lixo está aí. Agora a gente tem que reciclar estas pessoas, as donas de casa elas não aceitam, acham que é bobeira, deixar o lixo misturado, os detritos, papel higiênico essas coisas assim.

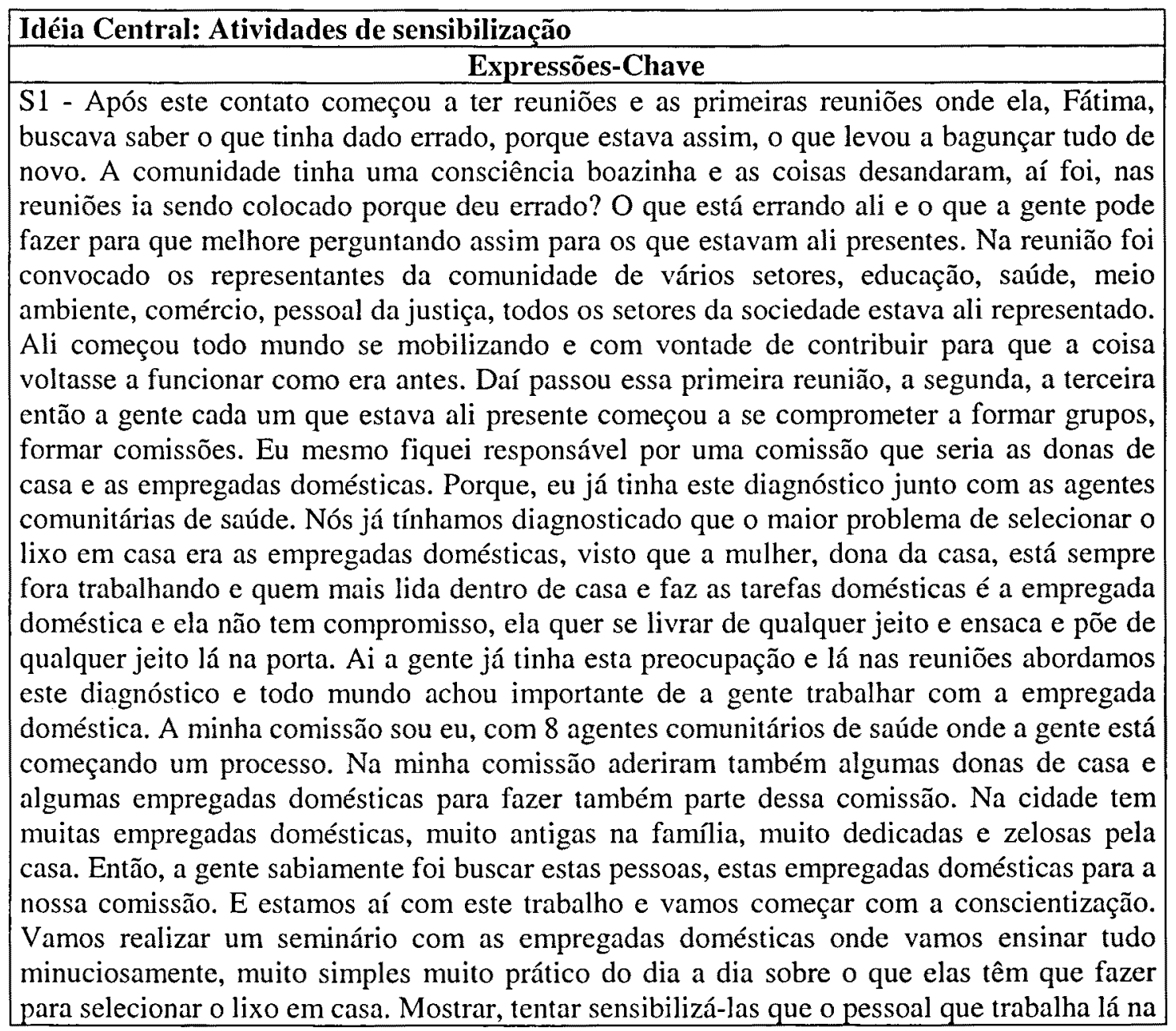


usina são pessoas iguais a nós que ficam recebendo esse lixo de qualquer jeito e se eles forem receber esse lixo melhor vai ser melhor para todo mundo, inclusive para a saúde deles e para o melhor aproveitamento do próprio lixo. Que tem lixo que vai muito sujo, sacos plásticos melado e misturado com coisas sujas que não vai aproveitar nada. Então nosso grupo está assim formado, uma enfermeira, 5 agentes comunitários de saúde e três empregadas doméstica e três donas de casa. Depois dessa reuniões, teve um seminário e teve um dia aqui até festivo onde a CAR junto com Fátima toda a administração da prefeitura fez um dia mostrando como é que o lixo pode ser reaproveitado. Várias vasilhas foram transformadas em brinquedo plástico, garrafa de guaraná, água mineral, tampinhas várias coisas que a gente joga no lixo e pensa que não serve de nada foi transformado em brinquedos. Então a população teve uma participação muito boa, o alunado todo esteve presente e todo mundo envolvido no processo que agora se comprometeu também estava presente, com banda de música tal. Teve também mostragem de como reciclar o papel, e o pessoal com a mão na massa mesmo aprendendo e fazendo e tal. Então a exposição desses brinquedos todo, o papel depois de reciclado foi reaproveitado, então foi uma boa sensibilizado esta parte aí.

S2 - A cidade não tinha muito lixo, tinha pouco daí a escola resolveu fazer uma campanha onde os alunos saíram em turma com os professores saiam em cada ponto da cidade recolhendo o lixo daí depois de todo o lixo recolhido foi levado para a praça, daí que deu a idéia da usina da reciclagem, para ajudar a população a separar o lixo e não ter muito lixo na rua. Os alunos também saíram de casa em casa explicando como seria separado o lixo, e daí, ia para a usina separado. Agora o pessoal parou de separar, só que está voltando de novo e estão separando o lixo e lá faz o que tem que fazer mesmo, vai separado e eles colocam nos seus devidos lugares. O projeto parou porque não teve a influência da escola e daí parou. Teve a divulgação, deu folhetos para os alunos e eles saíram explicando de casa em casa. Gincana que teve o título de Reciclagem. Também, e sem a influência dos professores os alunos tiveram que criar, eles só davam um tema e a duração da peça e os alunos tinham que criar.

S3 - Quando inaugurou da primeira vez há três anos atrás, a CAR pediu apoio do colégio e fomos nos pontos turísticos da cidade, ao redor da cidade recolhendo o lixo que tinha e fez mutirão, teve festa, organizamos, recolhemos todo o lixo. Logo depois o diretor do colégio pediu aos alunos da minha turma, para sair de casa em casa explicando para as pessoas e distribuindo os folhetos.

S6 A Bahia é um estado muito grande para Mucugê ser escolhida a cidade da reciclagem. Eu adorei. Não lembro do projeto. Teve passeatas na rua sobre o lixo, inclusive teve esta reciclagem ai, teve a usina. Teve um dia que o colégio liberou para a gente fazer a limpeza dos rios, dividiu a equipe por salas, o terceiro ano em cada rio, cada professora responsável por uma turma e aí fazia limpeza, trazia e colocava na praça de eventos e a tarde foi pesar o lixo. Foi maravilhoso pelo menos beira do rio... porque o povo daqui não faz muito sujeira já pegou o hábito da limpeza

S7 - Quando eu estava na escola eu lembro que a gente fez passeata nas ruas explicando ao pessoal como se fazia com o lixo dentro de casa para não prejudicar o pessoal que trabalhava aqui na Usina, separar direitinho.

S10 - Olha aqui já teve um evento no mês retrasado, em março, onde eles reimplantaram a usina de lixo, porque ficou um tempo parado, um ano anterior que teve a inauguração, eu não me lembro quando, daí o pessoal tudo direitinho, teve o mutirão para todo mundo pegar o lixo e depois disto eles resolveram fazer um outro na reimplantação porque tinha parado tudo, ninguém estava separando, aquela coisa desorganizada. Então eles reimplantaram foi o maior evento, trouxe um monte de gente, inclusive eles ensinaram muitas pessoas a usar o lixo como trabalho educativo, fazer brinquedos, cartões, então foi muito bom. Agora o resultado assim a gente ainda não sabe o que deu, mas a intenção é voltar a separar o lixo e voltar como era antes, porque é bom para a cidade você usar o lixo como uma coisa para não 
ficar aquela sujeira na cidade e educar as pessoas a separar o lixo.

S16 - Aqui a gente tem os professores que trabalham muito neste sentido, a gente teve uma, duas três vezes no dia Nacional de Meio Ambiente. Eles vão, fazem catação de lixo nos arredores e também o interesse que os prefeitos tem neste sentido.

\section{Idéia Central: Projeto relacionado à Usina que proporcionou melhoria da questão do lixo na cidade.}

S8 - Eu acho ótimo. Que sempre as coisas correm bem, nunca faltou nada, educação. Sobre a coleta do lixo é ótimo também. Aqui em casa eles mandam separar eu estou fazendo, eles pediram para fazer a nossa parte que eles estão fazendo a deles. Eu acho interessante porque vai para a usina para fazer reciclagem eu acho ótimo isso aí.

S9 - Antigamente aqui era horrível em todo o canto que você passava tinha lixo. Só depois de uns tempos para cá começou a se organizar. Antigamente não tinha como transportar o lixo, o pessoal carregava o lixo numa carrocinha. Era até engraçado era uma carrocinha com um burrinho e daí depois disto arrumaram o carro e começou a carregar, construíram a usina e acho que melhorou muito, começou a reciclar. Eles começaram a tirar o lixo, no fundo do quintal mesmo, Ave Maria, tinha rua que a quantidade de lixo, cada pessoa que passava assim, nos fundo do quintal era para queimar, era lata, saco, bastante mesmo.

S16 - Na nossa cidade você vê é uma das mais limpas da região e todo mundo está pronto para reclamar se alguma coisa assim não está direito. Estes dias colocaram um balde para recolhimento de lixo aqui e a gente reclamou para não deixou ali, cada pessoa vai botar o lixo no horário correto e o carro passa para pegar. Esse lixo é levado para uma usina lá é reciclado, as partes que podem ser recicladas eles levam para outro usina, não sei onde funciona, é Feira ou Salvador, mas aqui mesmo na Bahia. A outra parte do orgânico é transformado aqui mesmo, o lixo orgânico é transformado em adubo orgânico aqui na cidade mesmo, lá na parte da Fazenda Aracinópolis a entrada é ali. Eu achei um trabalho muito bonito porque foi bem explicado com várias reuniões, horário de colocar o lixo, a separação do lixo então foi uma coisa muito bem feita e o pessoal está indicado para isto e está funcionando.

S17 - Eles montaram uma usina de reciclagem em Mucugê, e ajudou bastante aqui na cidade porque antes ficava uma bagunça total, as pessoa jogavam lixo no quintal do outro, na rua, no fundo da minha casa era um lixão. Aí com este projeto limparam a rua toda e colocaram e como tem a usina tem a separação do lixo e a coleta do lixo todos os dias.

\section{Idéia Central: Projeto relacionado à usina e a outros projetos e necessidades}

S3 - Foi criada a usina de reciclagem que aproveitava o lixo, tem o projeto Sempre Viva, porque a sempre viva é a planta da cidade, daí entrou em extinção porque o pessoal tirava para vender para fora e daí criou o parque e o projeto é que gerencia o parque e eles plantam a sempre viva para ela não acabar.

S4 - O projeto de Educação Ambiental foi iniciado na gestão do prefeito Fernando Medrado, na qual houve uma conscientização da população principalmente dos alunos, onde técnicos de Salvador e da Católica vieram aqui dar cursos, seminários para que houvesse essa conscientização e daí para podermos trabalhar com os alunos para haver uma reprodução do que era na verdade o objetivo deste projeto. Foi iniciado na gestão de Fernando Medrado praticamente a conscientização. Na outra gestão do outro prefeito foi que tivemos a oportunidade de ganhar essa usina de reciclagem em que houve outro processo de conscientização, trabalhando principalmente com o lixo, como deveria ser usado o lixo orgânico e inorgânico. Neste período, as coisas andaram muito bem, daí a cidade teve um crescimento muito rápido e hoje há a necessidade de uma reconscientização porque vieram 
muitas pessoas morarem aqui que não estão inteiradas deste processo. Há necessidade de fazer novos projetos para chamar a atenção da população, para que elas também se encaixem neste grupo que já está conscientizado. Também se fala muito das queimadas, também há cursos que o pessoal daqui vai sempre para Lençóis e outros locais para saber como lidar com as queimadas que prejudica muito; temos também a questão da água que é essencial para a saúde e que necessita ser uma água boa de qualidade que nós não temos. Temos água em quantidade mas não em qualidade, e temos também a questão da rede de esgoto porque a relação saneamento e saúde estão ligadas e nós não temos ainda. Estamos procurando mas como é um investimento caro até hoje não foi possível Mucugê ter, pelo menos na sede. É praticamente isto e finalizando esta parte, a conscientização da preservação de toda esta natureza, de toda esta beleza, de todos estes mananciais que temos aí e que devemos ter consciência disto e fiscalizar também para que as pessoas que venham de fora não possam destruir.

\begin{tabular}{|l|}
\hline Idéia Central: Eu sei pouco sobre o projeto \\
\hline \multicolumn{1}{c|}{ Expressões-Chave } \\
\hline $\begin{array}{l}\text { S12 - Eu nunca fui em uma reunião, então eu faço do meu jeito, separo lixo de casa, lixo de } \\
\text { cozinha, banheiro separado, plástico separado, vidro separado, cada um numa sacolinha } \\
\text { separado. Na minha casa é assim. }\end{array}$ \\
\hline $\begin{array}{l}\text { S13 - Muito pouco. Eu não participo de quase nada, nem vou a reunião na cidade, } \\
\text { principalmente ambiental, devido ao tempo; os horário são sempre na parte da manhã e é um } \\
\text { horário que eu não posso freqüentar. Sei que eles gostam de conservar muito, aqui as coisas } \\
\text { são muito bem conservadas, mas não sei muita coisa não. }\end{array}$ \\
\hline
\end{tabular}

\section{Expressões-chave obtidas da pergunta: Na sua opinião o projeto mudou alguma coisa em Mucugê? Fale sobre isto.}

\section{Iléia Central: Mudou a consciência das pessoas}

\section{Expressões-Chave}

S1 - Mudou, porque as pessoas começaram a ter consciência que deviam separar o lixo porque além de ajudar a comunidade ia trazer grande benefício porque ia gastar bem menos, porque iam pagar menos pessoas para separar o lixo

S3 - Mudou, em conscientização. Só que a proporção em que mais pessoas vieram ele não foi divulgado para chegar a estas pessoas, então nós moradores mais antigos já estamos conscientes do nosso papel, agora essas outras pessoas que estão chegando não estão, então além de a gente fiscalizar nós temos a obrigação de conscientizar.

S7 - Antes era mais ruim, agora está melhor. Antes não pedia para separar, ninguém separava, misturava tudo, depois que surgiu isto aí, achei muito bom.

S10 - Mudou o pessoal tem mais conhecimento sobre o lixo, sobre o ambiente, aonde deve ser colocado o lixo, ....é um projeto que deu uma animada no pessoal para separar esse lixo

S17 - Mudou, na limpeza geral da cidade e as pessoas tiveram a consciência, nem todos mas boa parte das pessoas a maioria delas tiveram consciência e estão começando a separação do lixo, ajudando no projeto.

\section{Idéia Central: Mudou a cidade}

S4 - Mudou a cidade porque antes jogavam o lixo em qualquer lugar, agora tem lugar próprio para o lixo. As pessoas também jogavam o lixo no fundo das casas, acho que mudou bastante . 
S5 - Mudou, a cidade fica limpa, se uma pessoa joga uma lata de refrigerante na rua eu vou lá e pego, eu fico até com vergonha mas eu faço isto: eu vou lá e pego e jogo no lixo.

S6 - Mudou, no aspecto de limpeza e proteger mesmo o ambiente da região porque o ambiente, apesar da cidade ser turística e os turistas vê uma cidade suja, hoje em dia não, é limpa, tudo reaproveitado

S8 - Mudou muito. Porque hoje em dia você anda nas ruas e não vê aquela quantidade de lixo que incomodava, até quando chovia o cheiro era insuportável

S9 - Mudou porque o pessoal ficou bem educado com este negócio de lixo e você pode reparar a cidade não tem papel, não tem copo, não tem lata jogado, o pessoal é super educado, todo mundo joga no lixo certinho. A cidade é muito limpa, então quem entrar aqui vai sempre notar que é uma cidade educada com relação ao lixo. Antigamente não era tão sujo, mas o pessoal não tinha educação porque sempre teve o pessoal que varre a rua nunca deixou de deixar limpa a rua, mas você encontrava papel de bala, o jardim estava sempre com papel e hoje você não vê isto, está tudo muito limpinho e quem vem aqui diz: oh! vocês têm uma cidade muito bem educada em relação ao lixo porque todo o mundo joga no lugar certo e antes não era assim. Não era tão sujo mas melhorou com relação à antes.

S11 - Acho que melhorou. Limpeza da rua a higiene melhorou, quer dizer quando eu cheguei aqui já tinha higiene a rua já era limpa.

S13 - Acho que mudou, ainda não tanto, resultados ainda não se está tendo de concreto, mas digo assim resultado de impacto ainda não causou mas pelo processo que está vindo aí vai ter um bom resultado. Primeiro um resultado ambiental porque, já parou de jogar lixo no lixão, este lixo está tendo outro destino. O lixo hospitalar mesmo está tendo um aterrozinho sanitário, então esse lixo todo está sendo direcionado para este aterro sanitário e claro que os benefícios são muito grande e tem o benefício também comercial de rentabilidade.

S14 - Eu acho que sim porque, veja bem, em 1995 quando seu Fernando Medrado entrou como Prefeito de Mucugê, a cidade não tinha nem coleta de lixo aí se começou a fazer a coleta de lixo com uma carrocinha puxada por uma mula, depois entrou uma Toyota, foi quando eu entrei na Prefeitura em 95, até então os becos da nossa cidade, aquelas transversais eram todas tomadas pelo lixo. A cidade tinha muito rato, muito inseto a gente vivia constantemente colocando remédio no quintal para matar os bichos e depois da implantação da usina a gente percebeu que diminuiu na quantidade de inseto na cidade; a quantidade de rato não se proliferam mais. Então eu acho que a usina mudou a vida da população para melhor, porque hoje a população vive num ambiente limpo, bem cuidado. A prefeitura em si se preocupa muito com o trabalho de limpeza da cidade, tanto com o pessoal da usina que é o pessoal da coleta de lixo e da seleção de material como do pessoal de capinação e varrição. A maioria dos becos são todos limpinhos, capinadinhos pode ser de chão batido, que é tudo limpo. As ruas são muito bem varridas muito bem capinada. Então eu acho que mudou para melhor porque a vida antes era muito mais difícil aqui.

S15 A cidade não é tão suja, não vê tanto lixo na rua.

S16 Mudou muito, porque antes o lixo era espalhado, perto desse morro alto, logo depois do cemitério, eles colocavam o lixo, mas era fedido, era ruim de passar e o contorno e agora o lixo tem um local para ser colocado.

\begin{tabular}{|l|}
\hline Idéia Central: Não mudou \\
\hline \multicolumn{1}{|c|}{ Expressões-chave } \\
\hline S2 - Conscientizou um pouco a população, mas eu estou achando que agora está um pouco \\
esquecido este negócio da coleta porque têm famílias que não sabe qual o horário que vai \\
passar para pegar o lixo reciclável, o horário para pegar o lixo não reciclável. Aí mudou um \\
pouco porque esqueceu, porque na época estava lembrando, tinha a rádio que divulgava daí o \\
pessoal colocava o lixo separadinho agora não, nem todas as casas separam o lixo, está um \\
pouco esquecido mas não mudou muito não. \\
\hline S12 - Não, eu achei que está parado, antes era bem mais desenvolvido \\
\hline
\end{tabular}




\section{Expressões-chave obtidas da pergunta: Houve mudança pessoal em relação ao projeto?}

\begin{tabular}{|l|}
\hline Idéia central: Mudou \\
\hline \multicolumn{1}{c|}{ Expressões-chave } \\
\hline S2 - Mudou muito porque a gente trabalhando com isto a gente aprendeu a cuidar, viu as \\
coisas que iam prejudicar o meio ambiente e a gente sabe reciclar e fazer para que isto não \\
prejudique. Em casa mesmo é eu que separo o lixo, eu aprendi muito com este negócio de \\
meio ambiente, tem a aula de turismo no colégio e aí fica bem legal. Nesta disciplina a gente \\
vê tudo, como preservar a natureza, quais os benefícios econômicos e sociais que traz para a \\
cidade, tudo.
\end{tabular}

S3 - Provocou bastante, no geral porque na verdade a gente tinha a teoria mas não fazia a prática, você sabia o que era certo mas não fazia e a partir dessa participação, desse projeto, desses cursos, desses seminários nós começamos a por $\mathrm{em}$ prática o que é importante, porque saber todo mundo sabe, mas fazer é que é o importante.

S5 - Para mim foi bom porque hoje a gente não mistura mais o lixo. Por exemplo se hoje quebra uma lâmpada em casa ou um copo a gente não joga disponível, eu enrolo num jornal, coloco num saco de arroz ou de café que está ali no balde de lixo e daí jogo no lixo, porque quando chegar lá eles vão pegar eles podem cortar a mão como aconteceu muitos casos aqui. A partir de que começou a reciclagem eu já faço isto direto, os meninos do lixo que trabalham no lixo dizem que é um dos lixos melhores de Mucugê.

S6 - Mudou. Antes eu jogava o lixo fora, no meio da rua, vinha o pessoal pegava e jogava no lixão, eu não sabia de nada. Depois que veio este projeto o pessoal começou a ensinar na escola daí eu fui botar na minha cabeça que estava prejudicando o meio ambiente. Antes não traziam o lixo para aqui, jogavam no lixão, queimava estava prejudicando o meio ambiente.

S7 - Muitas coisas a gente está jogando fora, está jogando dinheiro fora, muitas coisas que se aproveita ainda

S8 - Mudou sim. Eu acho muito bom, porque viver numa cidade igual a que a gente vivia eu acho que nenhum ser humano gostaria de viver

S9 - Eu acredito que mudou. Mudou porque a diferença de você jogar um lixo em qualquer lugar e jogar no lugar certo e saber como ele vai ser deteriorado tudo, muda porque se você jogar este lixo em qualquer lugar além do mau cheiro ia ficar, ia sujar o local, não ia dar certo, a pessoa ia passar e ver aquele monte de lixo como tem em algumas cidades que elas jogam no lixão, no buraco e queimam tudo, mas mesmo queimando fica porque os animais carregam para outro lugar. Aqui ficou bom por isto eu acredito que este projeto do lixo é muito ótimo e que pode mudar muitas coisas erradas que tem em relação a essas imundícies que fica estas porcariadas

S10 - Eu aqui no hotel e em casa acabo separando o lixo. Colocando a parte separada, o resto de comida numa vasilha que a gente dá para os animais e os outros numa lixeira para talvez ir no lixo

S11 - Eu acho que sim porque o lixo todo misturado dá problema, principalmente porque aqui chove muito e isso tudo vai acabar dentro da água e vai contaminar as pessoas.

S13 - Mudou muito. Eu estou em qualquer lugar e se descasco uma bala automaticamente jogo no bolso e se não vejo onde jogar, já guardo na bolsa ou no bolso. Quando vou para a minha cidade Jequié, lá não tem isto, esse processo e estou fazendo alguma coisa lá estou eu separando as coisas na cozinha. Ah! Meu Deus aqui não precisa não seleciona nada, então já está com este sentimento e fica com aquele desejo de que em todo lugar estivesse acontecendo isto. Então afetou diretamente, primeiro neste sentido e depois na questão profissional mesmo que a gente vê que muitas doenças surgem do lixo, do acúmulo de lixo, muitos insetos, microorganismos proliferam a partir dali.

S15 - Sim também porque aqui em casa a gente fiscaliza, a gente vê onde está colocando a garrafa, onde está colocando o lixo orgânico, onde está colocando o papel higiênico porque a 
gente separa e hoje a gente usa isto para educar os menores, você coloca aqui, sobrou coloca aqui, a banana sobrou coloca aqui se for uma garrafa, um copo que partiu também sabe onde colocar, então ajudou também em casa, a manter o asseio e o cuidado, achei muito bom.

S15 - Então, tudo que vem em benefício para a natureza, ainda mais este negócio da camada de ozônio que está aí. Nós somos um dos poucos privilegiados com a natureza que temos, nós vivemos numa cidade com área urbana de $1 \mathrm{~km}$, mas muito bem cuidada, uma cidade limpa, ar puro rios para tomar banho, dá para tomar banho, apesar do Rio Mugugê, um rio muito bonito, mas infelizmente ele está proibido tomar banho.

S17 - Mudou sim, porque a gente aprende muita coisa, a separação do lixo. Ás vezes eu ficava na dúvida do que era orgânico e o que era inorgânico, então com este projeto e na época que eu estudava começou bem na época que eu estudava então eu aprendi bastante sobre isto. Coleta de lixo, separação do lixo, como era feita, como eles faziam lá na usina, que o lixo orgânico utilizavam para fazer adubo, isso é muito bom e o pessoal de casa fica sabendo disto não vai jogar de todo o jeito para lá, os restos de comida e restos de verduras que serve como adubo também, então é muito bom.

\section{Idéia central: Mudou porque eu vivo disto}

\section{Expressões-chave}

S14 - Para mim foi bom porque, como vou explicar eu participo diretamente do projeto. Eu começo na coleta, depois venho para a separação, hoje administro o esquema da usina, pesagem, prensagem, venda de material, recepção de visitante. Para mim particularmente melhorou porque hoje eu tenho um trabalho seguro, desde que feito direitinho e participo de tudo isso aí e tenho um padrão de vida muito bom.

\begin{tabular}{|l|}
\hline Idéia Central: Não Mudou \\
\hline \\
\hline S1 - Acho eu que não \\
\hline S12-Também não. \\
\hline
\end{tabular}

\begin{tabular}{|l|}
\hline Idéia Central: Já era educado sobre meio ambiente \\
\hline \multicolumn{1}{|c|}{ Expressões-chave } \\
\hline S4 - Eu sempre com esta questão de ser guia defendi o meio ambiente sempre fui já um \\
pouco educado em relação a isto. Houve alguns cursos com os guias mas um trabalho \\
mesmo não
\end{tabular}




\section{Expressões-chave obtidas da pergunta: Você participa de alguma forma neste projeto? Fale-me sobre isto.}

\begin{tabular}{|c|}
\hline Idéia Central: Não participo do projeto, só em casa como cidadã fazendo a minha parte \\
\hline Expressões-chave
\end{tabular}

S4 - Não participo no projeto, só como cidadão, eu fiscalizo de modo geral os visitantes se o povo daqui joga lixo no chão a gente vai lá e pega. Em casa eu tenho a prática de separar

S5 - Eu não tenho participação nenhuma, normal, eu peguei, fui lá na reciclagem e vi o trabalho deles na usina. Eles põem a mão naquele lixo podre, cheio de bicho, eu já preparava o meu: uma lata de manteiga eu jogo água fervendo, vou lavo, danone, catchup lavo, nunca jogo sujo, eu sempre faço isto. Faço porque é bom para comunidade só que muitos não fazem isto. Desde que começou a reciclagem eu faço e continuo fazendo se isto acabar eu vou continuar fazendo porque para mim não pesa, não dá trabalho de separar o lixo da gente todos os dias uma sacolinha, o outro é terça e quinta a partir das duas, só que não coloco nesses dois dias, só uma vez por semana porque não tem muito lixo e não fede, está tudo lavadinho.

S7 - Não. Só em casa a gente separa o papel e coloca em uma sacola; verdura a gente coloca em outra tudo separado em sacola.

S8 - Eu faço a minha parte em casa, separo sempre o lixo como eles sempre avisou para poder separar o lixo e a gente sempre procura fazer a nossa parte. O papel higiênico eu separo, as latas, restos de alimentos, cascas de verduras e tudo eu sempre procuro fazer a minha parte.

S12 - Não. Só separo o lixo, se tem alguém que colabora aqui sou eu. Separo o lixo, não coloco na rua não deixo as crianças jogarem o lixo na rua, estou colaborando de alguma forma. Gero muito lixo aqui, separo as latas do papel e da comida, e o papel higiênico separado também, tudo separado, só não lavamos as latas porque não tem tempo e não coloco na rua, coloco os sacos separados lá no quintal aí o rapaz abre de manhã e pega, porque na rua o cachorro abre.

S16 - Não, participo desta maneira que estou te falando, cuidando. Se eu vejo uma coisa na rua fora eu chamo o fiscal falo com ele, sempre estou atenta a isto, as vezes o córrego ali está obstruindo, porque passa um córrego ali, é um esgoto a céu aberto, então qualquer problema eu vou lá e falo. Está entupindo, é só dando um jeito, eu sempre falo. Tem este problema de colocar o lixo fora de hora eu e Ivete fala com o próprio morador eu falo com o fiscal e ele vem vai direto na casa e chama atenção, sem me identificar mas ele vai dizer que está havendo uma reclamação de um morador e tal e a coisa funciona. Então eu participo assim, não faço parte do grupo e da associação mas eu faço a minha parte. 


\section{Idéia Central: Participo na separação do lixo da minha casa e/ou da empresa \\ Expressões-Chave}

S9 A gente da pousada separa lixo. Tem cada lixo de cada cor, por exemplo lata vai em um, cascas de verdura tem um rapaz que ele trabalha e essa parte quase a gente não joga no lixo porque ele joga para os porcos, os porcos comem, no caso. A parte que a gente mais separa é lata, restos de plásticos, papel, caixas esses negócios, a gente separa e tem as vasilhas e tudo está separadinho. Agora o projeto ficou meio bagunçado, eu não sei se a usina está reativada, mas o pessoal não estão separando, o pessoal de casa não estão conscientizados, porque antes tinha rádio e tinha avisos tudo certinho e tinha que a pessoa separar o lixo. Eu acredito que hoje não estão separando como antes. Cada estabelecimento tem que separar o lixo e lá na usina eles chegam com o lixo separado, então se eles não chegam com o lixo separado lá, atrasa o trabalho deles. Então eu não sei como que está porque faz muito tempo que eu não vou lá. Mas este trabalho que eles fizeram no mês de março foi para reiniciar e botar tudo para funcionar novamente.

Eu participei desse evento de relançamento, deste último que teve aqui na praça. Então eu não sabia, uma parte que eles falaram que tinha que lavar as vasilhas de catchupe, refrigerante. Então se não tivesse tido esse evento eu não poderia saber. Teve até uma peça dos alunos lá que eles falavam que o lixo tinha que ser todo limpinho, mesmo que ele ia jogado no lixo ele tinha que ser limpo. Então precisa do lixo limpo para reciclar, eu não sei como funciona lá, mas teve também aquelas garrafas de refrigerante de 2 litros que você pode fazer tanta coisa com ela, o papel então se não tivesse tido, eu vejo muitos alunos no colégio que elas fazia umas cestinhas de revistas e jornais. Hoje eu vejo que muitas crianças fazem aquela cestinha porque aprendeu naquele tempo, nesse evento que teve. Então educando as pessoas e mostrando que além de jogar fora ele pode servir como um brinquedo, um porta jóia, um cartão então a pessoa vai vendo reciclar como ela aprendeu e não vai ser jogado o lixo no lixo. Só esse evento não serve, porque eu acredito que deve ter mais, pois eu vejo que muitas pessoas vão lá e aprende mas tem muitas pessoas que não interessa de ir ou talvez não pode sair na hora para ir então devia ter outra coisa, um aviso, não sei como deveria ser trabalhado isso, alem de eventos deveria ter algo mais para incentivar isso e não esquecer nunca de separar, não esquecer nunca dessa regra, ela deve incluir isto na vida dela.

S10 Só desta forma mesmo assim. De casa mesmo eu colaboro com este projeto. Mas de outra forma não, as vezes falta até tempo

S11 A participação é só em casa, eu nunca fui em reunião, estava ocupada, foi anunciado no carro de som mas eu nunca fui.

S17 Participo assim através da separação do lixo, porque aqui na loja como o lixo é inorgânico a gente separa tudo, às vezes vem as pessoas com um potinho de danone, a gente sempre lava então joga na lixeira da rua porque eles sabem como fazer lixo daqui porque eu jogando aqui dificulta um pouco o trabalho deles na usina. Então eu sempre separo, as vezes tem uma coisa orgânica como casca de fruta essas coisa então eu ponho dentro de uma sacola e não ponho no lixo aqui da loja que é inorgânico levo os dois separados.

\begin{tabular}{|l|}
\hline Idéia Central: Participo de várias formas \\
\hline \multicolumn{1}{|c|}{ Expressões-chave } \\
\hline S1 - Eu ajudei a distribuir os folhetinhos e também participei do concurso de melhor frase, \\
melhor cartaz e fiquei em terceiro lugar, a frase era "A ferramenta adequada para acabar com \\
o lixo somos nós mesmos". A gente acaba com o lixo é não jogando o lixo na rua é evitando. \\
Eu ajudei a distribuir, explicando nas casas e fiz a frase. Lá em casa de vez em quando \\
separa porque não tem muito lixo e tem quintal e separa o lixo. Tem os dias certos para \\
colocar o lixo na rua orgânico e inorgânico, daí separa, lá em casa também é assim. \\
\hline
\end{tabular}


S2 Participo assim ajudando, eu participei explicando para as pessoas, participei do mutirão e participo dentro de casa separando o lixo.

S6 Como cidadão alertar o pessoal que não entende do projeto

S13 Eu participo neste sentido que surgiu esta vontade de se engajar mais diretamente, antes eu já participava como falei, como dona de casa, como mulher, como cidadã e hoje eu participo como profissional mesmo, como colaboradora mais direta e desejando que este projeto venha dar certo. Então tudo na vida a gente tem que ter nossa parcela de contribuição para que a gente quer tanto que dê certo a gente tem que contribuir, não pode ficar sentada esperando.

S14 Participo diretamente. Eu fui treinado pelo pessoal da CAR por Fátima Gutierres, por Millena que é da Faculdade de Feira de Santana, que foi a primeira bióloga que esteve aqui e nos ensinou o processo de compostagem e tudo, então eu participo diretamente. Fui treinado para poder ajudar o pessoal, primeiro para fazer a coleta, depois fazer a seleção do material. Então eu participo diretamente e tenho orgulho de participar porque é um projeto piloto e hoje, pelo que nós sabemos, vai ser copiado para mais 10 municípios do estado da Bahia, porque este aqui deu certo, apesar de ter algumas deficiências, mas ele deu certo.

S15 No nosso trabalho a gente orienta as donas de casa sobre o lixo, como separar, que não deve colocar comidas junto com lata, vidro depois de ser usado lavar e deixar escorrer a água para não dá mosca. Aqui em casa eu separo, garrafas potinho de manteiga eu geralmente reutilizo, eu lavo também e jogo sempre limpinho, garrafa de leite de coco eu lavo, massa de tomate em lata eu lavo e os lixo assim agora aqui em casa não tem, porque cascas de alimento eu jogo no quintal para adubar porque o solo é arenoso e você planta alguma coisa e não dá então a gente joga no quintal, verduras, cascas de fruta que joga mesmo é só papel, latas garrafas, se quiser dá uma olhadinha.

\begin{tabular}{|c|}
\hline Idéia Central:Participo através do nosso trabalho \\
\hline Expressões-Chave \\
\hline $\begin{array}{l}\text { S3 - Só através da aula, eu procuro sempre que posso, se estou trabalhando com um texto, já } \\
\text { que sou professora de língua portuguesa, um texto que abrange esse assunto, eu estou sempre } \\
\text { trabalhando, mostrando aos alunos e direcionando para que eles se conscientizem disto, mas } \\
\text { é só praticamente nisto aí. Diretamente no projeto eu não trabalho, até porque não tenho } \\
\text { tempo. }\end{array}$ \\
\hline $\begin{array}{l}\text { S15 - No nosso trabalho a gente orienta as donas de casa sobre o lixo como separar, que não } \\
\text { deve colocar comidas junto com lata, vidro depois de ser usado lavar e deixar escorrer a água } \\
\text { para não dá mosca. Nós fizemos um trabalho aí, tem uns } 20 \text { dias sobre a dengue e aqui em } \\
\text { Mucugê se diz que tem o mosquito mas aqui não tem, não é infectado, fizemos um trabalho } \\
\text { de conscientização das famílias passamos de casa em casa, olhamos os quintais, plantas. }\end{array}$ \\
\hline
\end{tabular}

\section{Expressões-chave obtidas da pergunta: Em que aspecto o projeto poderia ser melhorado? Fale-me sobre isto"}

\begin{tabular}{|l|}
\hline Idéia central:Não precisa de melhorias \\
\hline \multicolumn{1}{|c|}{ Expressões-Chave } \\
\hline S8 - Eu acho que se ele continuar jgual ao que estão fazendo eu não tenho que dizer não \\
\hline $\begin{array}{l}\text { S15 - Saneamento básico, acho que tem que começar por aí, sem saneamento básico fica } \\
\text { quase que impossível. Que não adianta, é igual você limpar a casa e jogar o lixo na porta não } \\
\text { adianta, você entra na casa é uma maravilha, limpinha mas joga o lixo na porta. Para Mucugê } \\
\text { ficar bom mesmo é começar por saneamento básico, esgoto e tratamento de água. }\end{array}$ \\
\hline $\begin{array}{l}\text { S17 - Por enquanto está bom, agora se eles pudessem melhorar, por exemplo chegar em } \\
\text { outros municípios e passar isto para frente seria muito bom não só para a gente como para a }\end{array}$ \\
\hline
\end{tabular}


natureza também, que tem muitas coisas agressivas para a natureza como o vidro que pode causar incêndio, o plástico que a terra não decompõe. Então eles pudessem levar, para frente seria muito bom para natureza.

\section{Idéia Central: Divulgação/conscientização e mobilização Expressões-Chave}

S2 - Acho que deveria divulgar mais, divulgar mais o projeto, porque as vezes a gente até esquece que tem a usina de reciclagem na cidade. Então deveria divulgar mais, está faltando divulgação, está faltando organização, planejamento mais adequado.

S3 - O projeto tem necessidade de modificar algumas coisas, eu acho que na verdade o que falta para este projeto melhorar é a conscientização total, porque se as pessoas tem consciência elas vão fazer correto. Para isto precisa mais divulgação através de programas, de peças de teatro em praça pública que é uma coisa que todo mundo tem acesso, criar ações de jingles para colocar no carro de som para que a cidade toda fique ouvindo aquilo e aí vai dando o estalo do que dever ser feito, propaganda, cartazes estas coisas para que esteja sempre presente no cotidiano das pessoas para que não aprenda hoje e esqueça, faça de conta que aquilo acabou então tem que estar sempre presente isto aí. $\mathrm{E}$ até para o próprio turista, porque tem muito turista educado mas também tem muito turista mal educado, eu moro ali na praça e vejo direto. Então eles chegam, bebem refrigerante, jogam a lata na rua, bebem um iogurte e jogam a lata na rua, comem biscoito e jogam o papel na rua então para eles também, se tiver uma coisa mais estampada, mais vista até repreende a eles, eu acho que deveria ser feito isto. Porque aqui vem muito turista conscientizado, porque quando está dentro do projeto Sempre Viva ele já entra receoso, aqui eu não posso, mas ele esquece quando chega na rua faz, chega ali adiante não está a fiscalização e faz. Então se tivesse em todos os locais estampado para ele ver, ele despertaria mais e se policiava mais.

S5 - Que todos fizessem isto como eu, porque são poucos. Acho que deveria ter uma reunião, com as donas de casa, inclusive quando passo na rua e vejo tudo misturado me dá vontade de separar porque já acostumei. Se tivesse mais reuniões com as donas de casa, mais participação eu acho que melhorava mais.

S6 - Deveria melhorar mais se fizesse mais campanhas, colocasse mais pessoas para orientar o pessoal na rua porque está vindo muito lixo sem separar e pelo que a gente está vendo, pelo jeito ninguém está entendendo sobre o projeto, só precisa melhorar nesta parte.

S9 - Eu acho que deveria vim mais constantemente o pessoal, ter um trabalho uma coisa assim, tipo incentivar o pessoal de alguma forma, com prêmio, alguma coisa assim, porque o pessoal está muito desanimado, então talvez incentivando eles, fazendo alguma coisa para eles separar o lixo dando uma gratificação, qualquer coisa tipo que incentivasse outros tipo. Ele recebeu um prêmio eu também vou lutar vou fazer a mesma coisa para receber, vou separar o meu lixo. Acho que precisa de um incentivo porque o pessoal está meio desanimado com essa separação do lixo, não sei porque de repente, por falta de aviso também acho bom a pessoa estar sempre em casa avisando. De repente o rapaz do lixo está sabendo qual o lixo que não está vindo separado então ele podia passar isto para o gerente da usina e ele tinha uma conversa com essa pessoa, conversasse e convencesse ele de uma forma educativa para ele separar esse lixo, se o pessoal está ficando fraco tem que vir alguém para reforçá-los.

S10 - Eu acho que fazendo mais propaganda, divulgando mais este projeto em ruas, residências e nessa parte comercial deveria ser mais divulgado.

S11 - Nem sei, melhorar se todo mundo fizesse, ajudasse separar o lixo, para sempre. Se tivesse uma reunião para explicar as pessoas como deveria ser, pois muita gente não sabe.

S12 - Melhorando a reciclagem, a gente não vê o reciclado, eles reclama mas a reciclagem a gente não vê quase nada, do que fizeram, do que estão reciclando. Então eu acho que deveria ter mais atividade até para vender, ter oficinas de arte, de reciclagem e aqui não tem. A 
própria garrafa de água mineral, garrafa de coca-cola daria para fazer qualquer coisa, eu não vejo esse trabalho.

S14 - Eu acho que para melhorar só precisa mesmo da colaboração total da população. $\mathrm{O}$ esquema que foi feito pela CAR é um esquema certo, um esquema lógico da coisa funcionar. Infelizmente não funciona melhor por falta de colaboração de alguns. Então eu acho para melhorar é a colaboração da população fazendo a seleção prévia em suas casas. Para mobilizar a população é a pesquisa de corpo a corpo usando os alunos da escola. Este trabalho tem que começar dentro da escola, conscientizando as crianças a fazer este processo dentro da escola, daí ele leva para casa dele e vai cobrar do pai, da mãe, da empregada, eu acho que aí dá certo.

\begin{tabular}{|l|}
\hline Idéia Central: O projeto deveria tratar de emprego \\
\hline \multicolumn{1}{|c|}{ Expressões-Chave } \\
\hline S7 - Eu acho que deve melhorar e ajudar o pessoal assim sobre trabalho. Na cidade tem \\
muito pouco trabalho porque tem muita gente que precisa de emprego e não tem. O projeto \\
deveria tratar desse assunto
\end{tabular}

Idéia Central: Aumentar os vasilhames nas ruas e melhorar a parte operacional da Usina.

\section{Expressões-Chave}

S1 - Eu acho que deveria ter mais vasilha de lixo na rua porque tem pouca aqui, na cidade, na minha opinião deveria ter bem mais. Só colocam aquelas vasilhas grandes na rua quando vai ter festa, alguma coisa assim, exposição para o pessoal jogar o lixo depois disto tiram e não colocam mais. Eu acho que deveria ter bem mais.

S13 - A minha primeira crítica é que todo o serviço específico tem que ter um técnico específico para estar administrando este setor, então a minha crítica é a falta desse profissional dessa área mesmo, para estar acompanhando essa usina mesmo, estar supervisionando e tomando conta desse processo de perto. Quanto a esses funcionários que estão lá, esse pessoal de apoio, são profissionais muito comprometido, gostam muito do trabalho. A única crítica é que falta um profissional especifico para tomar conta direcionar as questões mesmo, não vejo outro, porque tudo é favorável a acontecer: a comunidade está começando a participar, sensibilizando, os setores da sociedade estão mobilizados, agora o que precisa também é um respaldo técnico da própria usina. Até acho se não houver o contrato desse profissional corre o risco de novo de desabar este projeto, é como se fosse um hospital sem médico.

S16 - Eu acho que poderia, principalmente neste problema de comportar o lixo da cidade. Talvez no momento em que ele foi feito, foi feito o projeto em si no número de habitantes que cresceu muito, eu estava falando com o rapaz que trabalha lá, é um absurdo o que vai de lixo por dia para lá, é mais de 2 a 3 toneladas não foi projetado para isto, e aí uma parte do lixo fica jogado lá nesses cerrados nos Gerais que a gente fala. Tem uma parte que separa que é o papel, que não é o orgânico que fica, que não ó vidro, não é a lata de óleo, mas é o papel higiênico o jornal velho que estão jogando aí que estava ficando feio. Eu reclamei também, reclamei não, falei estou achando isto feio as vezes até juntando urubu porque não deixa de ir alguma coisa orgânica, também já notei que melhorou, o pessoal aqui todo fiscaliza, todo mundo que passa quer ver limpo. Este problema de jogar latinha de refrigerante, pega o ônibus toma um refrigerante e joga, a nossa prefeita e o prefeito anterior tem um catador de lixo que vai aí do lado do asfalto até perder de vista catando. Então o que poderia melhorar era assim 


\section{Expressões-chave obtidas da pergunta: Lixo, você tem alguma coisa a ver com isto? Fale-me sobre isto.}

\begin{tabular}{|c|}
\hline $\begin{array}{l}\text { Idéia Central: Eu tenho a ver com o lixo porque o lixo vem da gente (eu produzo) } \\
\text { Expressões-Chave }\end{array}$ \\
\hline $\begin{array}{l}\text { S1 - Tenho, porque como todo mundo eu também uso as coisas e não preciso de muitas } \\
\text { coisas e as que não preciso vou jogar no lixo e acabo tendo alguma coisa a ver. }\end{array}$ \\
\hline $\begin{array}{l}\text { S2 - Tenho. Se tem lixo a gente tem que fazer alguma coisa, se a gente não jogasse o lixo na } \\
\text { rua, se a gente separasse o lixo, se a gente não jogasse nos pontos turísticos quando a gente } \\
\text { vai passear não teria lixo, então todos tem a ver um pouquinho com isso, duvido que não } \\
\text { tenha alguém que não joga um papelzinho de bala na rua e as vezes a gente esquece e joga. } \\
\text { Acho que todo mundo tem a ver com o lixo, lixo não vai nascer, não é planta para nascer né, } \\
\text { então vem da gente. }\end{array}$ \\
\hline $\begin{array}{l}\text { S5 - Lixo é aquilo que não serve mais para a gente, não tem utilidade nenhuma, nem } \\
\text { sempre... tem as coisas que jogam no lixo que tem utilidade para outras pessoas. Eu produzo } \\
\text { restos de comida e restos de fruta. }\end{array}$ \\
\hline $\begin{array}{l}\text { S13 - Tenho muito a ver, eu produzo muito lixo. A gente no dia a dia acaba produzindo } \\
\text { muito lixo. Não deveria mas o consumo humano ultimamente tem exagerado muito, apesar } \\
\text { de que hoje eu tento diminuir ele. Por exemplo as sacolas que vem de mercado se transforma } \\
\text { em sacola para colocar o próprio lixo que no momento não me serve mais mas que depois } \\
\text { numa transformação ele vir a servir poder colaborar, até voltar para a minha casa. Por } \\
\text { exemplo sai umas latinhas, papel, papelão sai da minha casa como lixo mas de repente olha } \\
\text { eu lá na frente trazendo ele de volta transformado podendo me servir ainda e a outras } \\
\text { pessoas. Então eu tenho muito a ver com o lixo e tenho que aprender muito mais a lidar com } \\
\text { o lixo e a não produzir também tanto lixo. }\end{array}$ \\
\hline $\begin{array}{l}\text { S8 - A gente sempre tem a gente mexe com isto o tempo todo. A gente sempre tem papel e } \\
\text { tem que retirar a sujeira de casa e a gente sempre tem a ver com o lixo por causa disto. }\end{array}$ \\
\hline $\begin{array}{l}17 \text { - Eu tenho a ver porque nós somos consumidores então sempre fica em casa alguma } \\
\text { isa, por exemplo embalagens, latas, porque a gente sempre come uma coisa enlatada. }\end{array}$ \\
\hline
\end{tabular}

\section{Idéia Central: Tenho e devo manejá-lo adequadamente \\ Expressões-chave}

S3 - Todos nós temos, o lixo faz parte da nossa vida porque podemos, sabendo utilizá-lo, reutilizá-lo e direcionar o que não poder ser utilizado, então o lixo faz parte do nosso dia a dia. Então não tem como separar então é saber trabalhá-lo e colocá-lo em local adequado.

S4 - Hoje se você passa aqui e joga uma latinha todo mundo fica de olho aí vai lá e pega e outro diz tem uma lixeira logo ali, então lixo é isso. Eu ajudo no que puder eu sempre estou ajudando, não jogo lixo no chão, não abro a porta do carro para jogar lixo no chão, isto aí e importante, se não tem lixeira vou jogar lixo fora.

S6 - Tenho, no meu trabalho e em casa mesmo. Na minha casa separo, todos aqui da usina separam, com certeza se fizer uma avaliação vem tudo separadinho.

S9 - A gente tem porque aqui é muito lixo, inclusive o pessoal estava reclamando que a gente não está separando, mas a gente produz bastante. Mas no caso o erro é da gente porque quem tem que estar separando e deixando tudo organizado é a gente.

S10 - Reciclando o lixo ele se torna uma coisa valorosa

S14 - Tenho porque eu sou um dos produtores de lixo, só que na minha casa nós fizemos a prévia seleção e aqui na usina a gente separa da melhor maneira possível, mas é aquele negócio, infelizmente nós temos pessoas ligadas à prefeitura, ligada a área de serviço público que não colabora. Por exemplo, vamos supor se eu não faço, não posso cobrar de meu vizinho não é isto? Mas o lixo em si a gente faz a seleção da melhor maneira possível e eu 
como um dos produtores de lixo, cobro da minha esposa dos meus filhos para que faça direito para a gente poder ver isto ir para a frente.

S15 - Temos, é o que mais orienta as pessoas é sobre o lixo, sobre a separação separar, recicláveis, não recicláveis, a gente olha os quintais nas ruas quando a gente vê lixo a gente entra em contato com a prefeitura porque nesse ponto eles apóiam a gente, apóiam os moradores e também do pessoal da prefeitura sem contar que temos o hospital também.

S16 - Todo mundo tem porque na nossa casa todo o dia nós temos o lixo, então se a gente se organizar e colocar este lixo no lugar certo, nunca nos vai aborrecer, nos atrapalhar. Para isto nós temos que fazer é educar os outros a fazerem a mesma coisa. Porque não adianta, a gente reclama, a gente troca de pessoa que mora com a gente, então descasca uma laranja e joga no quintal, então lixo é lixo mas tem que ser posto no lixo para dar certo

S17 - Se chupa uma bala tem o lixo, daí a gente tem que procurar uma lixeira para não sujara a cidade, para não poluir o ambiente, então o melhor é a gente recorrer a uma lixeira mais próxima e até mesmo colocando no bolso para não sujar a rua e manter a cidade limpa. Aqui muitas pessoas fazem isto, não jogam o lixo na rua eles põem no bolso. As vezes chega em casa e está com o bolso cheio de lixo para não jogar na rua e ajudar na limpeza da cidade

\begin{tabular}{|l|}
\hline Idéia Central: Não tenho nada a ver com o lixo \\
\hline Expressões-Chave \\
\hline S7 - Não \\
\hline S11 - Não \\
\hline S12 - Não, o que gera aqui é muito pouco e pode ser reaproveitado. \\
\hline
\end{tabular}




\section{ANEXO 4}

\section{ROTEIRO DA ENTREVISTA}

\section{IDENTIFICAÇÃO:}

Nome, idade e profissão

Há quanto tempo estuda (ou mora) neste local? Porque você mora (estuda ou trabalha) neste local?

1. O que você sabe sobre o Programa de Educação Ambiental desenvolvido neste local. Fale-me sobre isto.

2. Você acha que o projeto mudou alguma coisa na UEFS (ou município). Fale-me sobre isto.

3.O projeto mudou alguma coisa em você?

4. Você participa de alguma forma neste projeto? Fale-me sobre isto.

5. De que forma este projeto poderia ser melhorado?

6. Lixo o que eu tenho a ver com isto? Fale-me sobre isto. 


\section{ANEXO 5}

\section{TERMO DE CONSENTIMENTO LIVRE E ESCLARECIDO}

Aceito participar da pesquisa "Educação Ambiental no Gerenciamento Sustentável dos Resíduos Sólidos Urbanos," da pesquisadora Sandra Maria Furiam Dias, aluna de doutorado da Faculdade de Saúde Pública da Universidade de São Paulo.

Fui informado que a pesquisa pretende descrever e avaliar os Programas de Educação Ambiental desenvolvidos na Universidade Estadual de Feira de Santana, no Arraial de São Francisco da Mombaça e no município de Mucugê , BA.

Como participante da pesquisa serei entrevistado uma ou duas vezes pela pesquisadora com o auxílio do gravador, com duração máxima de 90 minutos, sendo esta entrevista marcada com antecedência.

Sei que tenho liberdade de recusar a participar da pesquisa e deixá-la a qualquer momento, sem qualquer prejuízo para a minha vida pessoal.

Fui também esclarecido (a) que meu nome não será divulgado nos resultados da pesquisa e as informações que darei serão utilizadas somente para os propósitos da pesquisa.

DATA:

Assinatura do entrevistado

DATA:

Assinatura da pesquisadora 